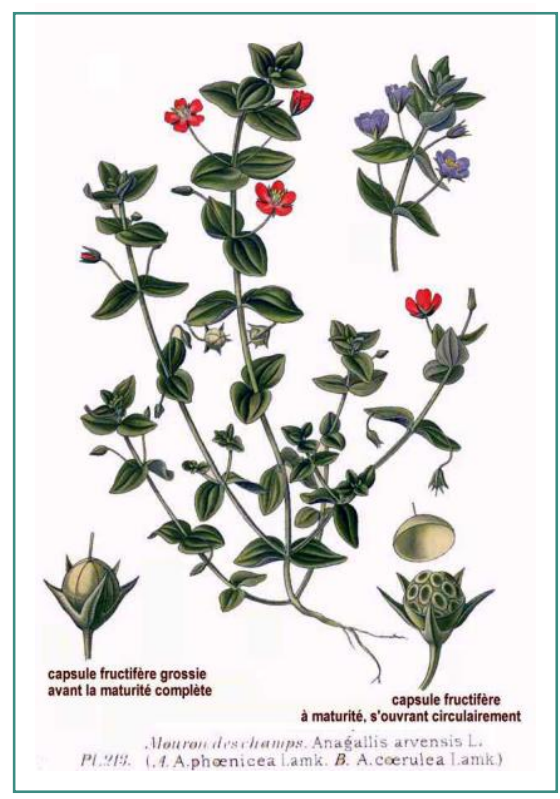

Anagallis arvensis. Atlas des plantes de France, A. Masclef (1891) 



\title{
ZENTRUM
}

FÜR BIODIVERSITÄT UND NACHHALTIGE LANDNUTZUNG

SEKTION

BIODIVERSITÄT, ÖKOLOGIE UND NATURSCHUTZ

- CENTRE OF BIODIVERSITY AND SUSTAINABLE LAND USE -

SECTION: BIODIVERSITY, ECOLOGY AND NATURE CONSERVATION

\section{Effects of different energy cropping systems on plant diversity in Central German agricultural landscapes}

\author{
Dissertation \\ zur Erlangung des Doktorgrades der \\ Mathematisch-Naturwissenschaftlichen Fakultäten \\ der Georg-August-Universität Göttingen \\ vorgelegt von \\ Charlotte Seifert \\ aus \\ Paderborn
}

Göttingen, August 2014 
Referent/In: Prof. Dr. Christoph Leuschner Korreferent/In: Prof. Dr. Erwin Bergmeier Tag der mündlichen Prüfung: 03.09.2014 


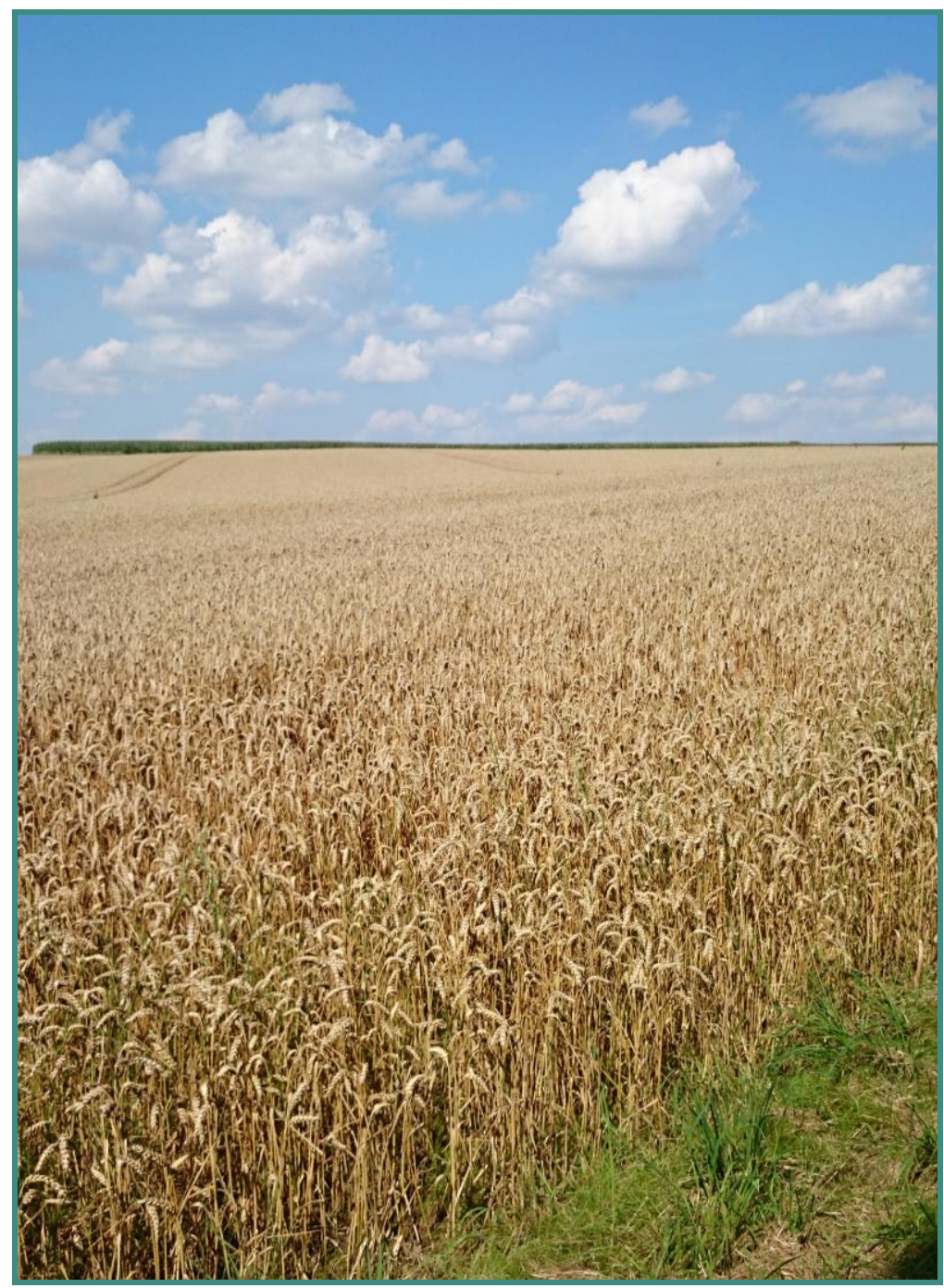

Wheat field in Central Germany. Picture by Charlotte Seifert, August 2012.

\section{Ein Weizenfeld}

Weil es die Ähre verschmäht, sich mit der Farbe zu zieren, Hat die Natur ihr den Mohn dicht an die Seite gestellt; Jener hat sie die Kraft vertraut, den Menschen zu nähren,

Diesem verlieh sie den Reiz, welcher sein Auge erfreut. Jene frage drum nicht: Wo sprießen dir nützliche Körner?

Oder diesen: Wo trägst du den erquicklichen Schmuck? Wenn die eine uns fehlte, so könnten wir freilich nicht leben,

Aber wir möchten es nicht, wäre der and're nicht da!

Christian Friedrich Hebbel (1813-1863)

German poet and dramatist 


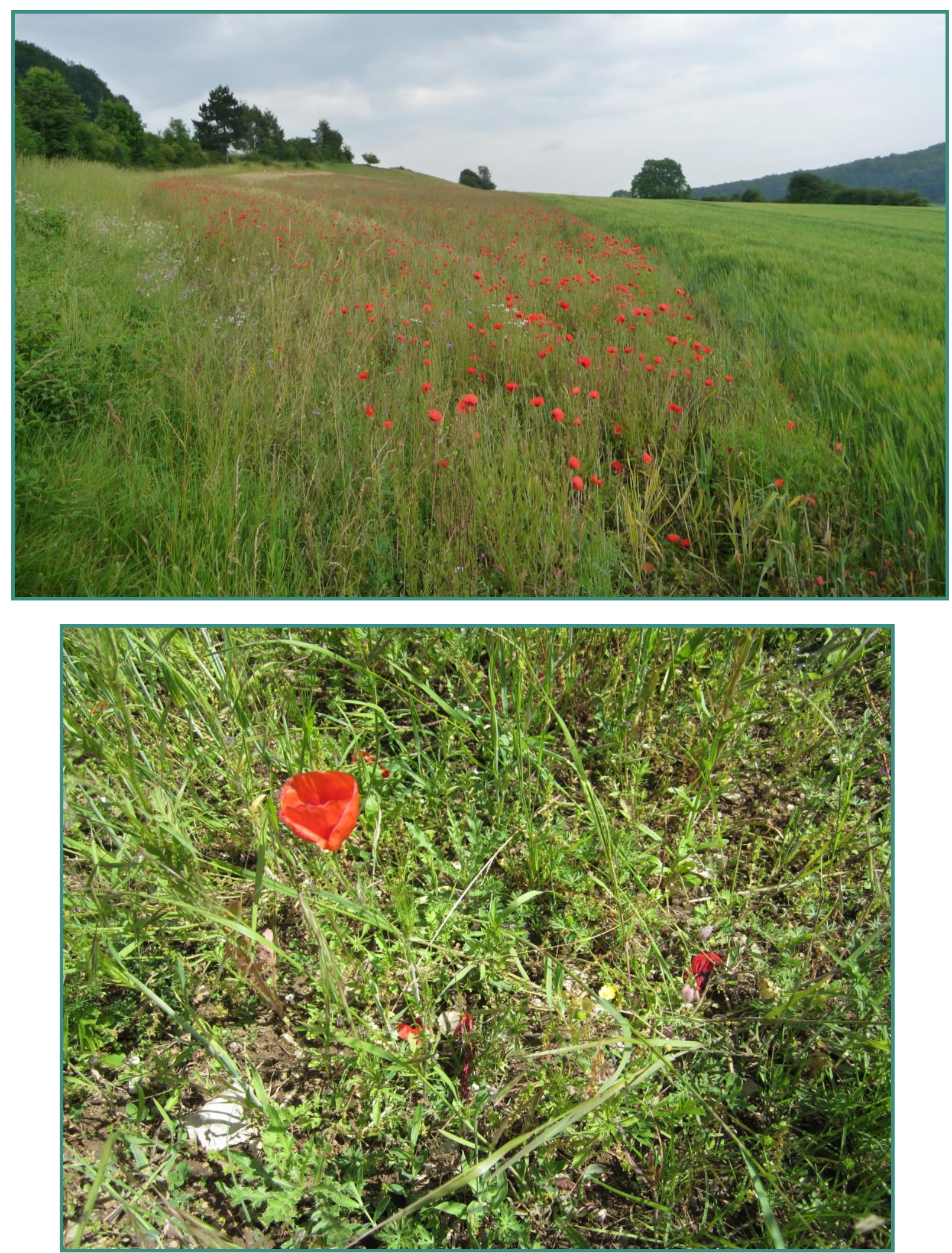

Impressions from an extensively managed field margin near Göttingen in Lower Saxony in June 2012. Pictures by Caroline Focke. 



\section{Table of contents}

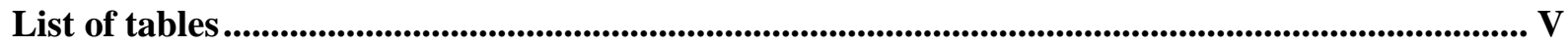

List of figures ...................................................................................................................................................................... VI

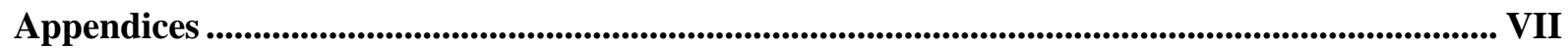

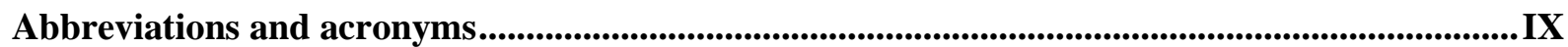

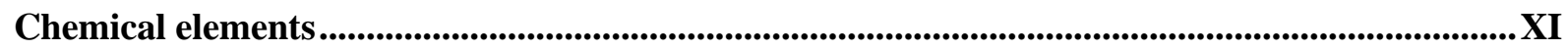

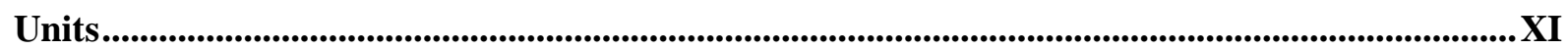

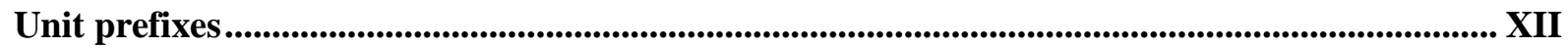

Acknowledgements.............................................................................................................................................. XIV

Summary .................................................................................................................................................XVI

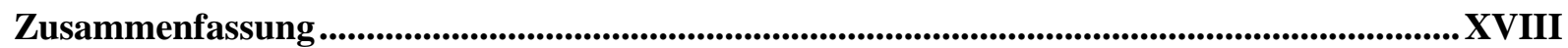

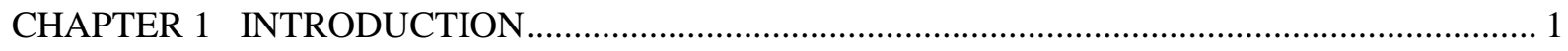

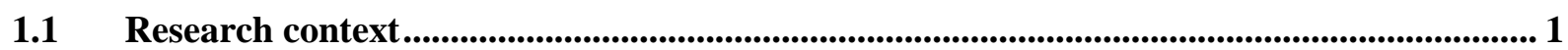

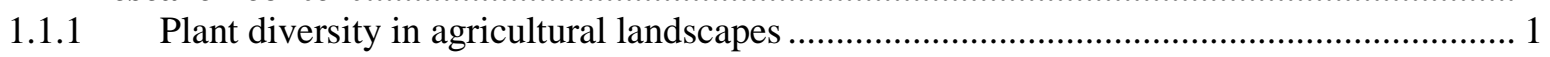

1.1.1.1 Arable plant assemblages as a mirror of agricultural land use practices ......................... 1

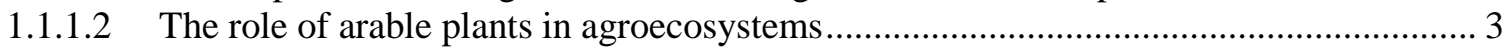

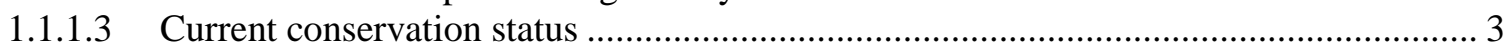

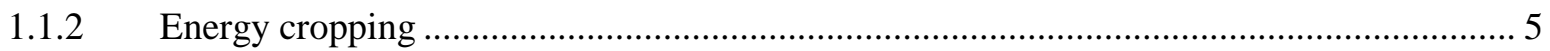

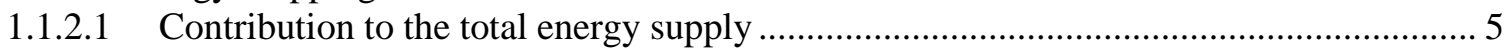

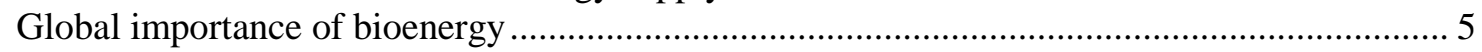

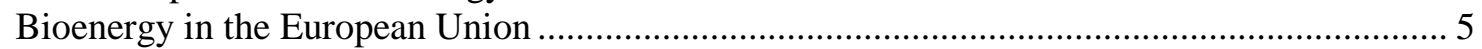

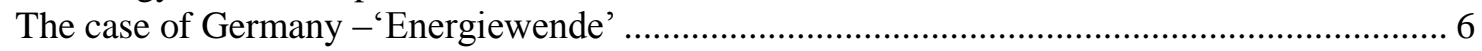

1.1.2.2 Conversion technologies and biomass feedstocks.......................................................... 7

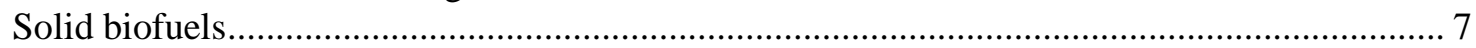

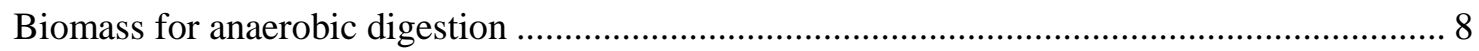

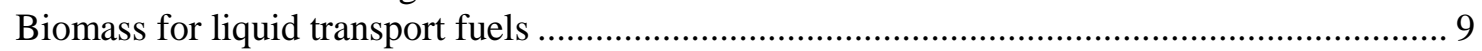

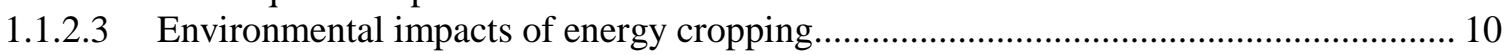

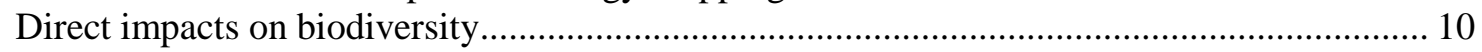

Direct impacts on the abiotic environment and soil organic matter cycles ............................... 12

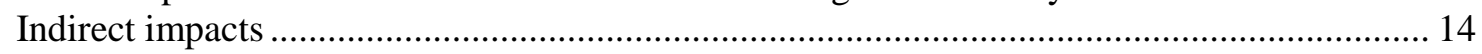

1.2 The study areas........................................................................................................................ 15

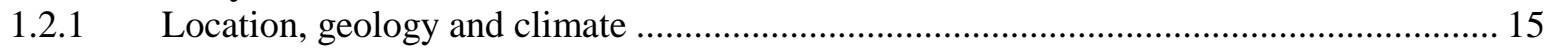

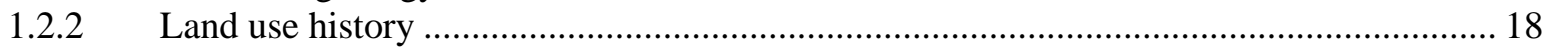

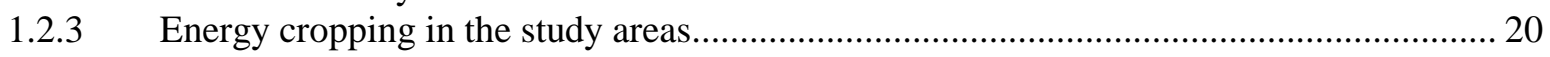

1.3 General description of the applied methods........................................................................ 22 


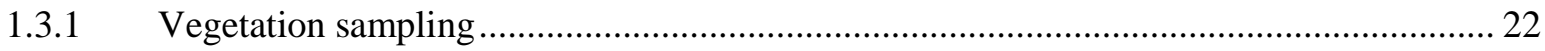

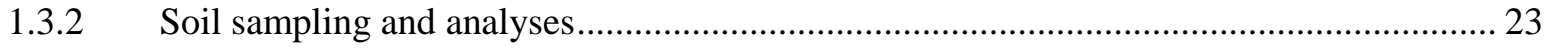

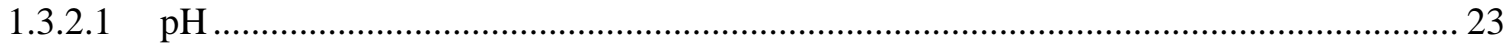

1.3.2.2 Effective cation-exchange capacity (ECEC) and base saturation................................. 23

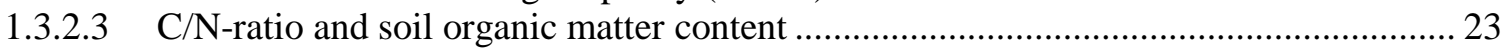

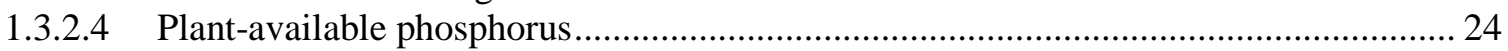

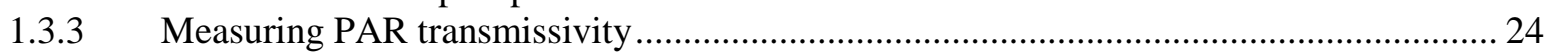

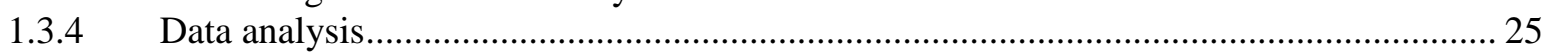

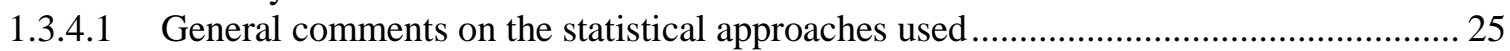

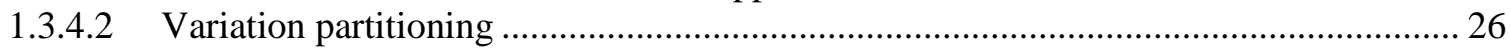

1.4 General objectives and outline of the chapters ............................................................................. 27

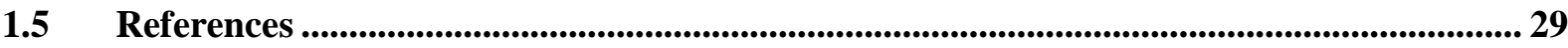

CHAPTER 2 ARABLE PLANT DIVERSITY ON CONVENTIONAL CROPLAND - THE ROLE OF CROP SPECIES, MANAGEMENT AND ENVIRONMENT …..................................... 37

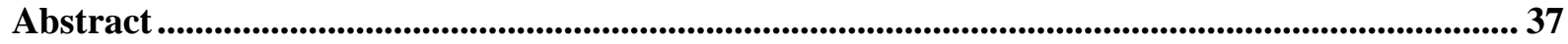

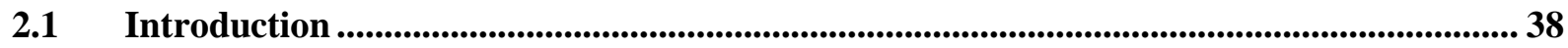

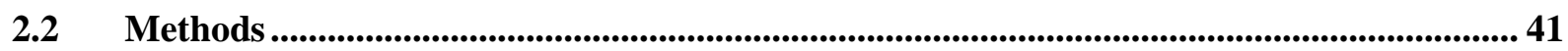

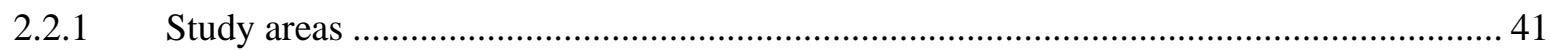

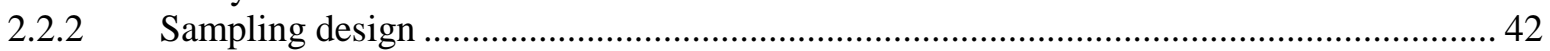

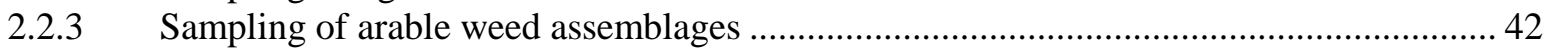

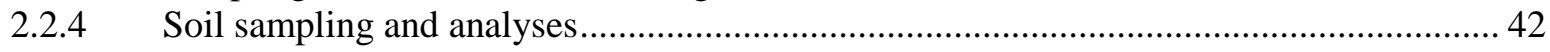

2.2.5 Derivation of environmental, management and spatial variables..................................... 43

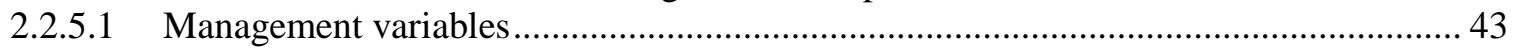

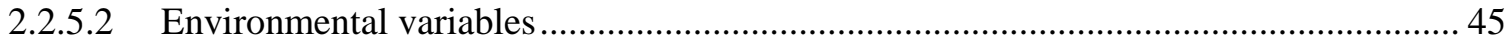

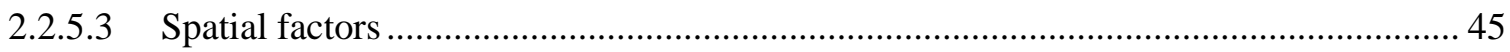

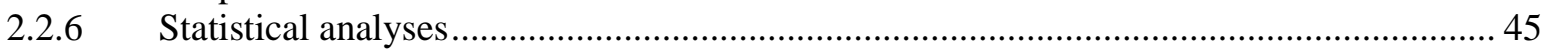

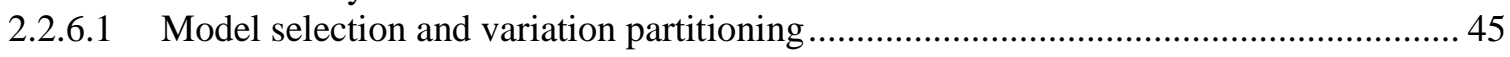

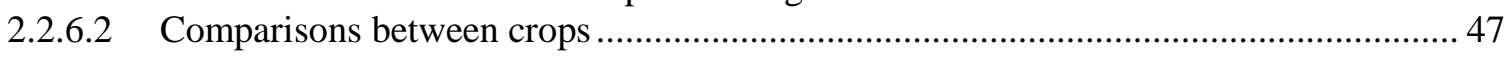

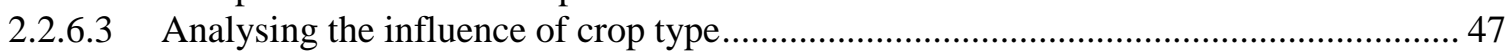

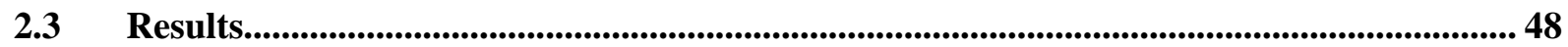

2.3.1 General importance of management factors for arable plant diversity............................. 48

2.3.2 Effects of specific management factors on arable plant diversity and interactions with

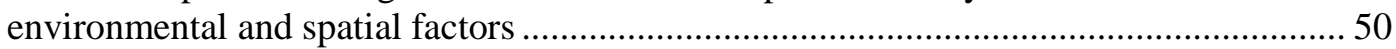

2.3.3 Importance of the current crop and interactions with other management factors .............52

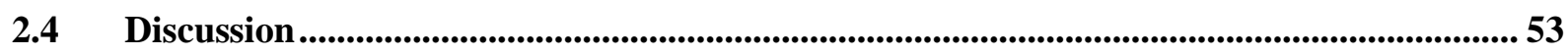

2.4.1 General importance of management factors for arable plant diversity ............................. 53

2.4.2 Effects of particular management factors on arable plant diversity and interactions with

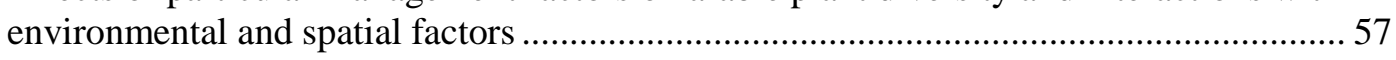

2.4.3 Importance of the current crop and interactions with other management factors ............. 60

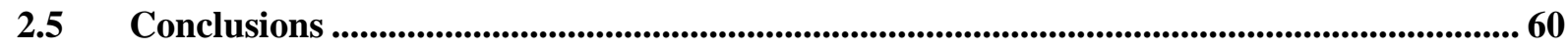

$2.6 \quad$ Acknowledgements ...................................................................................................................................... 61

$2.7 \quad$ References ............................................................................................................................................. 62 
Abstract

3.1 Introduction 68

3.2 Methods .................................................................................................................................................. 70

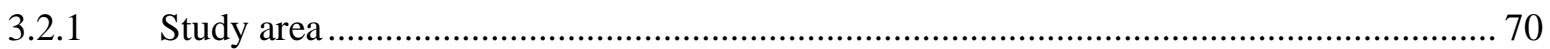

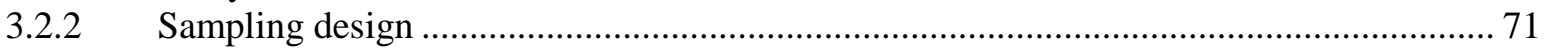

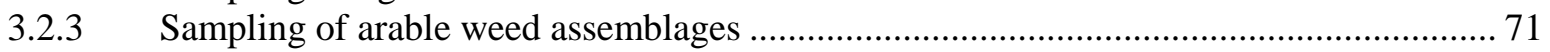

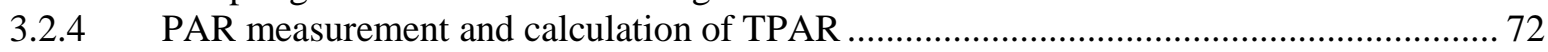

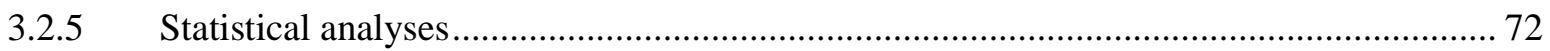

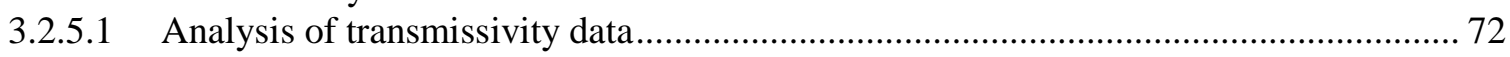

3.2.5.2 Analysing the effects of TPAR on the diversity of weed assemblages ............................ 73

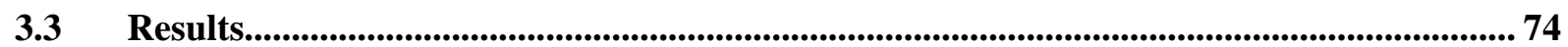

3.3.1 TPAR variability within and between different cropping systems ..................................... 74

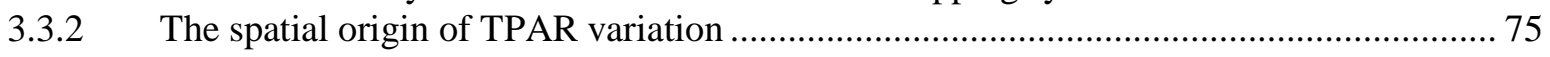

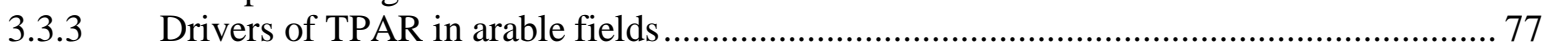

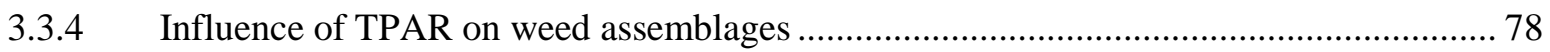

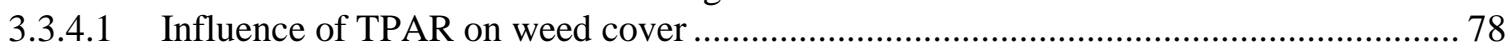

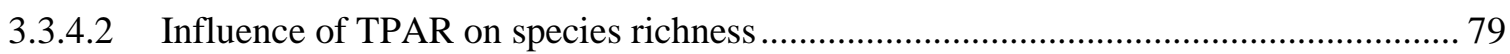

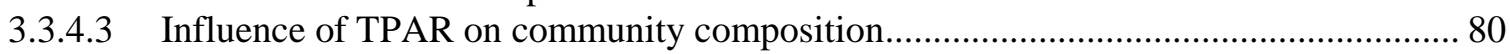

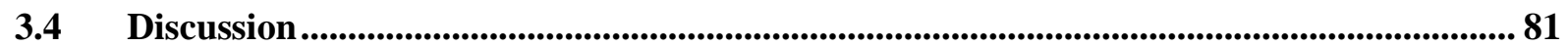

3.4.1 Light transmission patterns in different cropping systems .......................................... 81

3.4.2 The influence of TPAR on the diversity of weed assemblages ....................................... 83

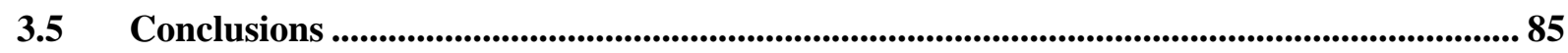

3.6 Acknowledgements ................................................................................................................................. 86

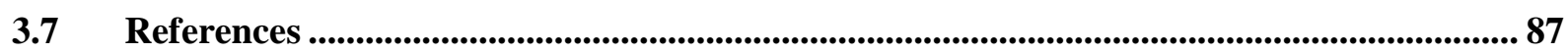

CHAPTER 4 SHORT ROTATION COPPICES AS HABITAT FOR VASCULAR PLANTS .......... 91

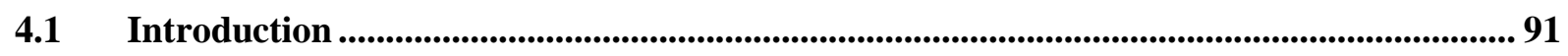

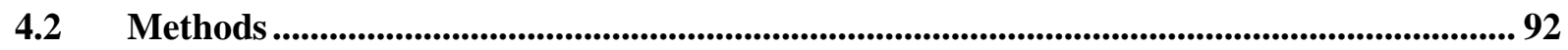

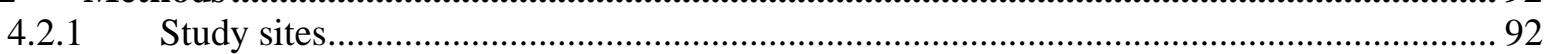

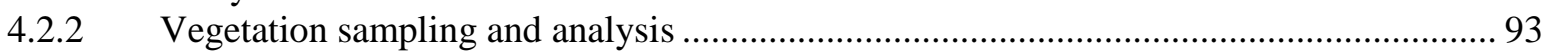

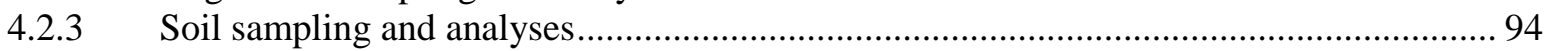

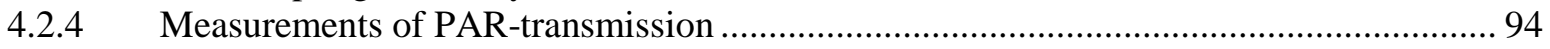

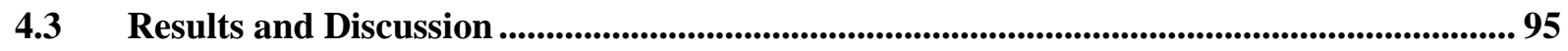

4.3.1 Habitat conditions and plant diversity in newly established short rotation coppices ........ 95

4.3.2 Habitat conditions and plant diversity in older short rotation coppice .............................. 98

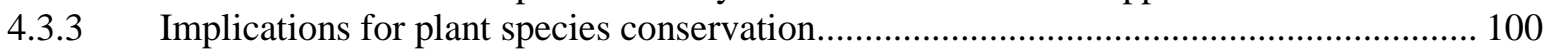

4.3.4 Management recommendations for the enhancement of plant diversity ......................... 101

4.4 Conclusions 
5.1 Influences of energy cropping on the plant diversity of agricultural landscapes ............ 107

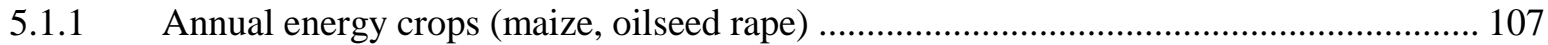

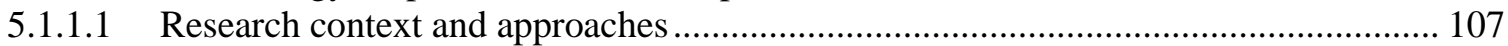

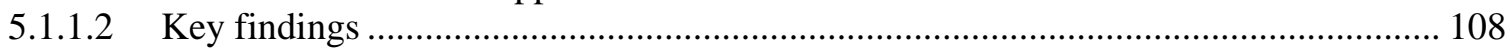

Arable plant diversity and growing conditions in the field interior and at the field margins .. 108

The influence of crop choice and field management ............................................................. 109

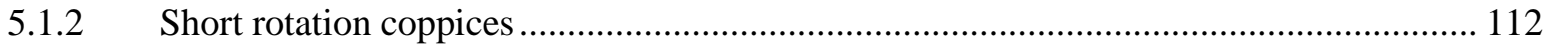

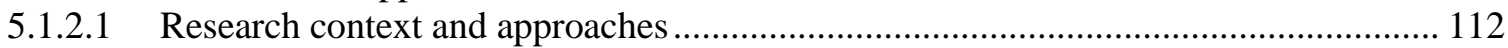

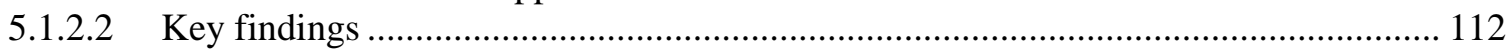

5.1.3 Short rotation coppices - a biodiversity friendly alternative to annual energy crops? .... 114

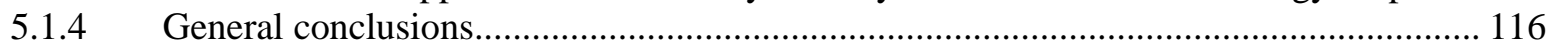

5.2 Open questions, uncertainties and future research perspectives ....................................... 117

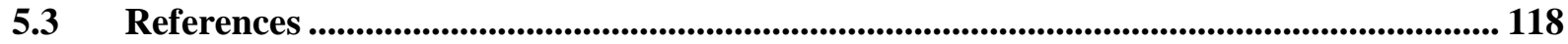

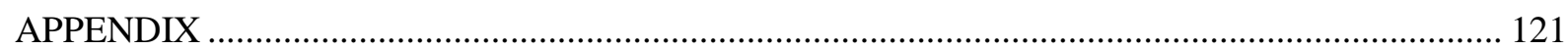

\section{List of tables}

Table 1.1 Braun-Blanquet cover abundance scale according to Wilmanns (1998) ........... 22

Table 2.1 Description of the predictors used for the analyses in the nine sets of variables ..... 44

Table 2.2 Final models for each of the six response variables sorted by the nine sets of predictors

Table 2.3 Gross and net effects $\left(\mathrm{R}^{2}\right.$ adjusted $)$ of different sets of variables on weed cover, species richness and community composition

Table 2.4 Gross and net effects $\left(\mathrm{R}^{2}\right.$ adjusted $)$ of management factors found to be interacting with the cultivated crop .............................................................. 5

Table 2.5 Differences in macro and micro environmental factors, soil chemistry and field management factors (fertilisation, herbicide use and crop rotation) between stands of conventionally managed maize, winter-sown wheat and winter-sown barley .... 55

Table 3.1 Variance of TPAR attributable to within-field, between-field, between-crop and between-region variation according to hierarchical variance component analysis .... 76

Table 3.2 Fractions of the variation in TPAR explained by crop cover, management factors (crop; management intensity: conventional management (conv.) vs. agrienvironmental schemes (AES)), and region (Lower Saxon hills vs. Thuringian Basin)

Table 3.3 Fractions of variation (adjusted $R^{2}$, in \%) explained by TPAR, management factors (crop; management intensity: conventional management (conv.) vs. agri- 
environmental schemes (AES)), and region (Lower Saxon hills vs. Thuringian

Basin) for total weed cover, species richness and community composition

Table 4.1 Characteristics of the SRC plantations studied 93

Table 4.2 Soil chemical properties of SRC in central Germany 96

\section{List of figures}

Fig. 1.1 Examples of arable archaeophytes ............................................ 2

Fig. 1.2 Examples of nationally endangered arable plant species ........................ 4

Fig. 1.3 Contribution of bioenergy to the global primary energy consumption .............. 5

Fig. 1.4 Contribution of bioenergy to the primary energy consumption of the EU ........... 6

Fig. 1.5 Contribution of bioenergy to the final energy consumption in Germany in 2012 ..... 7

Fig. 1.6 Area used for the cultivation of renewable resources in Germany (1999-2013) ..... 9

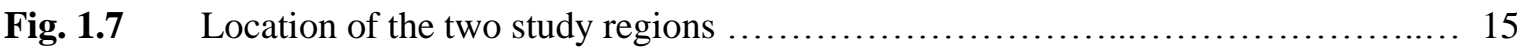

Fig. 1.8 Location of the sampling sites within the study regions ......................... 16

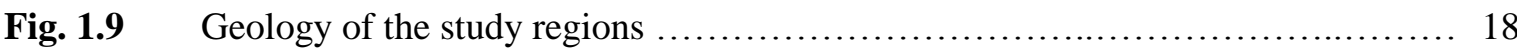

Fig. 1.10 Proportion of arable land used for the production of different crops in the study

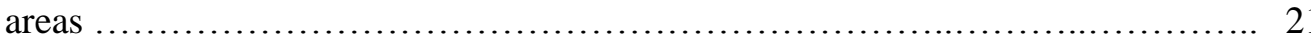

Fig. 1.11 Venn diagram representing the partitioning of variation between three sets of predictors

Fig. 2.1 Location of the two study regions

Fig. 2.2 Proportion of explained variation in arable plant cover, species richness and community composition attributable to field management and environmental factors .... 50

Fig. 2.3 Proportion of variance in weed cover in the field interior explained by fertilisation .51

Fig. 2.4 Relationship between (a) species richness at the field margin and S fertilisation during the preceding year and (b) species richness in the field interior and the amount of herbicides from class $\mathrm{K}_{3}$ (mitosis inhibitors)

Fig. 2.5 Differences in (a) total weed cover (in \%) and (b) species richness per sampling plot between fields cultivated with maize $(n=71)$, winter barley $(n=64)$ and winter

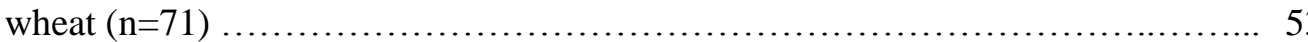

Fig. 3.1 Study areas in Lower Saxony and Thuringia, Germany ......................... 70

Fig. 3.2 Differences in (a) PAR transmissivity (TPAR), (b) total crop cover, and (c) mean number of weed species $100 \mathrm{~m}^{-2}$ of the weed assemblages (cover weighted) in the field interior (FI, grey boxplots) and at the field margin (FM, white boxplots) of four different crops in conventionally managed arable fields 
Fig. 3.3 Differences in TPAR, total crop cover and species richness between conventionally managed wheat fields (conv., $\mathrm{n}=10$ ) and wheat managed according to an agri-environmental scheme (AES, $\mathrm{n}=10)$

Fig. 3.4 Relative frequency of classes of PAR transmissivity (TPAR) to the soil surface (interval width: 5\%) in four different conventionally managed crops and winter wheat managed according to an agri-environmental scheme .... 77

Fig. 4.1 PAR transmittance (TPAR, in \%) in poplar and willow SRC in central Germany ... 96

Fig. 4.2 Number of vascular plant species found in SRC in central Germany by habitat preference of the species

Fig. 4.3 Number of vascular plant species found in SRC in central Germany by naturalisation status 98

Fig. 4.4 Value of SRC for plant diversity in agricultural landscapes relative to other land use options and management intensity 100

Fig. 4.5 Number of vascular plant species found at the edges (E) and in the interiors (I) of SRC in central Germany by habitat preference of the species 102

\section{Appendices}

\section{Chapter 1}

Appendix 1.A Data sheet as used for the vegetation survey

\section{Chapter 2}

Appendix 2.A Frequency of occurrence of species according to crop and in-field position

Appendix 2.B Questionnaire about the field management answered by the 60 participating farmers.

Appendix 2.C Additional information on certain variables

(a) Number of plots for each soil type separated by crop and in-field position.

(b) Number of plots for each geological substrate separated by crop and in-field position.

(c) HRAC herbicide classification system according to Menne and Köcher (2012)

Appendix 2.D Results of preliminary analysis steps

(a) Loadings of principal components (PCs) from PCA of different environmental variables.

(b) Complete theoretical models before backward selection.

\section{Chapter 3}

Appendix 3.A Frequency of occurrence of species according to crop type and in-field position 
Appendix 3.B Mean PAR transmissivity ( \pm SE) measured in the field interior (FI) and at the field margins (FM) of 50 arable fields with different cropping systems

Appendix 3.C Mean ( \pm SE) of TPAR (in \%), the crop cover, the weed cover and the total cover $(=$ crop + weed cover, all in $\%)$ and the mean number of species

\section{Chapter 4}

Appendix 4.A Frequency of occurrence of species recorded on SRCs according to the position of the plot, the plantation age, the survey season and the tree species including the naturalisation statu, the habitat preference and the life form according to Raunkiær 


\section{Abbreviations and acronyms}

Abb. Abbreviation

AD Anno domini

a.m. Ante meridiem, before noon

a. s. I. Above sea level

BEST Research framework 'Bioenergie Regionen Stärken' ('Strengthening Bioenergy Regions')

BfN Bundesamt für Naturschutz (German Federal Agency for Nature Conservation)

BKG Bundesamt für Kartographie und Geodäsie (German Federal Agency for Cartography and Geodesy)

BLE Bundesanstalt für Landwirtschaft und Ernährung (German Federal Office for Agriculture and Food)

BMBF German Federal Ministry for Education and Research

BMEL German Federal Ministry for Food and Agriculture (since 2014)

BMELV German Federal Ministry for Food, Agriculture and Consumer Protection (before 2014)

BMU German Federal Ministry for the Environment, Natur Conservation and Nuclear Safety

BS Base saturation (\%)

BtL Biomass to liquid fuels (conversion technology for biomass)

BÜK50 Bodenübersichtskarte 1:50,000 (soil map, scale 1:50,000)

CCA Canonical correspondence analysis

CEC (Potential) cation exchange capacity

Chpt. Chapter

$\mathbf{C}_{\text {inorg Inorganic soil carbon }}$

$\mathbf{C O}_{2} \mathbf{e} \quad \mathrm{CO}_{2}$-equivalents (measure for greenhouse gas emissions)

$\mathbf{C}_{\text {org }}$ Organic soil carbon

cp. Compare

$\mathbf{C}_{\text {tot }} \quad$ Total soil carbon

DCA Detrended correspondence analysis

DMK Deutsches Maiskomittee e. V. (German Maize Committee, agricultural association)

DW Dry weight

DWD Deutscher Wetterdienst (Meteorological Service of Germany)

E East

ECEC Effective cation exchange capacity

EEA European Environmental Agency

ed/eds Editor(s)

e.g. Exempli gratia, for example

et al. Et aliilet aliae, and others

EU European Union

EU-27 The 27 European Member States from January 2006 to June 2013

FI Field interior

Fig. Figure

FM Field margin

FNR Fachagentur Nachwachsende Rohstoffe e. V. (coordinating institution for research and development in the field of renewable resources in Germany)

GHG Greenhouse gas

GK50 Geologische Karte 1:50,000 (geological map, scale 1:50,000) 
GÜK500 Geologische Übersichtskarte 1:500,000 (geological map, scale 1:500,000)

HFA Handbuch Forstliche Analytik (book on analysis methods in the forestry sector)

HI Herbicide use intensity index

HRAC Herbicide Resistance Action Committee (association of major herbicide producers)

HVO Hydrogenated vegetable oils

ICP Inductively coupled plasma analyses

i.e. Id est

ILUC Indirect land use change

I.M.A. Information.medien.agrar e. V. (association for information, media and agriculture)

Inhib. Inhibitor

LBEG Landesamt für Bergbau, Energie und Geologie Niedersachsen (State Authority for Mining, Energy and Geology of Lower Saxony)

LPG Landwirtschaftliche Produktionsgenossenschaft (agricultural production cooperatives in the former German Democratic Republic)

LS Lower Saxon hills (study area)

LWA Landwirtschaftsamt (German county office for agriculture in Thuringia)

LWK Landwirtschaftskammer (German county office for agriculture in Lower Saxony)

N North

NABU Naturschutzbund Deutschland e. V. (nature conservation association)

n.d. No data

No. Number

NRW North Rhine-Westphalia

ns Not significant

$\mathbf{N}_{\text {tot }} \quad$ Total soil nitrogen

p./pp. Page(s)

PAR Photosynthetically active radiation

$\mathbf{P A R}_{\text {inc }}$ Incident PAR flux density $\left(\mu \mathrm{mol} \mathrm{m} \mathrm{m}^{-2}\right)$

PAR $_{\text {trans }}$ Transmitted PAR $\left(\mu \mathrm{mol} \mathrm{m} \mathrm{s}^{-2} \mathrm{~s}^{-1}\right)$

PC Principal component

PCA Principal component analysis

PCNM Principal coordinates of neighbour matrices

p.m. Post meridiem, after noon

Prop. Proportion

PS II Photosystem II

pyr Year preceding the field surveys

$\mathbf{R}^{2} \quad$ Coefficient of determination (regression), redundancy statistic (RDA, CCA)

$\mathbf{R}^{2}$ adjusted $\quad$ Adjusted $\mathbf{R}^{2}$ (see chapter 1.3.4.1)

RDA Redundancy analysis

SE Standard error of the mean

SOM Soil organic matter

SRC Short rotation coppice

SRU Sachverständigenrat für Umweltfragen (German Advisory Council on the Environment)

syr Year of field surveys

TB Thuringian Basin (study area)

TLL Thüringer Landesanstalt für Landwirtschaft (Thuringian State Office for Agriculture) 
TPAR PAR transmissivity $\left(=\mathrm{PAR}_{\text {trans }} / \mathrm{PAR}_{\text {inc }}\right.$, in \%)

UBA Umweltbundesamt (German Federal Environmental Agency)

UTM Universal Transverse Mercator (projected coordinate system)

VCA Variance component analysis

VG Verwaltungsgemeinschaft (municipality)

WGS World Geodetic System (geodetic reference system)

\section{Chemical elements}

Abb. Name

$\begin{array}{llll}\text { Al } & \text { Aluminium } & \text { Mg } & \text { Magnesium } \\ \text { Ba } & \text { Barium } & \text { Mn } & \text { Manganese } \\ \mathbf{C} & \text { Carbon } & \mathbf{N} & \text { Nitrogen } \\ \mathbf{C a} & \text { Calcium } & \mathbf{N a} & \text { Sodium } \\ \mathbf{C l} & \text { Chlorine } & \mathbf{O} & \text { Oxygen } \\ \mathbf{F e} & \text { Iron } & \mathbf{P} & \text { Phosphorus } \\ \mathbf{H} & \text { Hydrogen } & \mathbf{S} & \text { Sulphur } \\ \mathbf{K} & \text { Potassium } & & \end{array}$

\section{Units}

Abb. Name

$\begin{array}{ll}{ }^{\circ} & \text { Degree } \\ { }^{\circ} \mathbf{C} & \text { Minute } \\ \mathbf{g} & \text { Degree Celsius } \\ \mathbf{h} & \text { Gram } \\ \mathbf{h a} & \text { Hour } \\ \mathbf{J} & \text { Hectare } \\ \mathbf{L} & \text { Joule } \\ \mathbf{m} & \text { Liter } \\ \mathbf{m i n} & \text { Meter } \\ \mathbf{m o l} & \text { Minute } \\ \mathbf{t} & \text { Mole } \\ \mathbf{y r}, \mathbf{y r s} & \text { Ton } \\ \end{array}$

\section{Description}

Angle, geographical coordinate $1^{\circ}=0.0175 \mathrm{rad}=0.0175 \mathrm{~m} \mathrm{~m}^{-1}$

Angle, geographical coordinate $1^{\prime}=1 / 60^{\circ}=0.0003 \mathrm{rad}\left(\right.$ or m m$\left.{ }^{-1}\right)$

Temperature

Mass

Time

Area

Energy, work, amount of heat

Volume

Length

Time

Amount of substance

Weight

Time

\section{Expression in terms of SI} base units

$0{ }^{\circ} \mathrm{C}=273.15 \mathrm{~K}$

$$
\begin{aligned}
& 1 \mathrm{~h}=3600 \mathrm{~s} \\
& 1 \mathrm{ha}=10,000 \mathrm{~m}^{2} \\
& 1 \mathrm{~J}=1 \mathrm{~m}^{2} \mathrm{~kg} \mathrm{~s}^{-2} \\
& 1 \mathrm{~L}=10 \mathrm{~cm}^{3} \\
& - \\
& 1 \mathrm{~min}=60 \mathrm{~s} \\
& - \\
& 1 \mathrm{t}=1000 \mathrm{~kg} \\
& 1 \mathrm{yr}=31,536,000 \mathrm{~s}
\end{aligned}
$$


Unit prefixes

$\begin{array}{llllll}\text { Abb. } & \text { Name } & \text { Value } & \text { Abb. } & \text { Name } & \text { Value } \\ \mathbf{n} & \text { nano } & 10^{-9} & \mathbf{k} & \text { kilo } & 10^{3} \\ \boldsymbol{\mu} & \text { micro } & 10^{-6} & \mathbf{M} & \text { mega } & 10^{6} \\ \mathbf{m} & \text { milli } & 10^{-3} & \mathbf{G} & \text { giga } & 10^{9} \\ \mathbf{c} & \text { centi } & 10^{-2} & \mathbf{T} & \text { tera } & 10^{12} \\ \mathbf{d} & \text { deci } & 10^{-1} & \mathbf{P} & \text { peta } & 10^{15} \\ & & & \mathbf{E} & \text { exa } & 10^{18}\end{array}$




\section{Acknowledgements}

For contributing essentially to the successful completion of this thesis and supporting me throughout the work, I would like to particularly thank my supervisors PD Dr. Heike Culmsee and Prof. Dr. Christoph Leuschner. Sincere thanks also to Prof. Dr. Erwin Bergmeier for helpful advice and for offering me 'a home' (and an office) in his department. Additionally, I am grateful to my thesis committee Prof. Dr. Renate Bürger-Arndt, Prof. Dr. Johannes Isselstein, and Prof. Dr. Holger Kreft for taking the time to evaluate my work. All the things I learned during my time at the University of Göttingen changed my view on the world in many ways and will continue to guide and accompany me in my future life and work.

I would also like to heartily thank my parents Elisabeth and Horst for guiding me and giving me the freedom to become who I am now. A big thank you also goes to my sister Mareike for being there if I need her. Without your unconditional love and support my work on this thesis would never even have begun.

Thanks also to all the colleagues of the department of Vegetation and Phytodiversity Analysis for their advice and support and for allowing me to come to the office each morning with positive expectations. Particular thanks go to my office mates Parastoo Mahdavi, Oliver Fried and Nur Kumalasari and to Inga Schmiedel and Florian Goedecke for their friendship and for always being there to help me when tricky questions arose. I am also very grateful to Ute Wergen for digitising the farmers' questionnaires during long weeks of tedious work and to Brigitte Siegesmund for solving computer problems.

Sincere thanks also to Dr. Stefan Meyer for his continuous support and his contribution to chapter 3 of this thesis. Additionally, I would like to thank Jutta Czernitzki, Marianne Gescheidlen, Uta NüsseHahne, Ute Schlonsog, Dr. Heinz Coners and Dr. Dietrich Hertel for their advice and support with the soil analyses. Special thanks go to my field and lab assistants Kristina Röben, Conny Roth, Wiebke Retzlaff, Nina Kirchhoff, Tobias Lauermann, Jonathan Bepple, Christian Rikels, Caroline Focke and Birgit Keppler and to Melina Ortloff and Marie Sohn who contributed with their B. Sc. Theses to this work. The many kilometres on bumpy field tracks and the long hours in the lab were not for nothing!

This work was carried out as part of the research frameworl BEST 'Bioenergie Regionen Stärken' (section FA 1, Ecological Impact Assessment - Phytodiversity) funded by the German Federal Ministry of Education and Research (BMBF), 2010-2014. I am grateful to my colleagues from the research framework for sharing work and thoughts and to the BMBF for funding me. Furthermore, this work would not have been possible without the support of the 60 farmers who gave me access to their land and patiently filled the questionnaires! 
Last, but for sure not least, I would like to say thank you to Nele, Ricarda, Mona and Philipp, to my flatmates Till and Gabor and to all the other friends who made my life in Göttingen more happy and colourful and who lent an ear to the ups and downs of my student life.

THANK YOU ALL FOR MAKING MY TIME IN GÖTTINGEN UNFORGETABLE! 


\section{Summary}

The rich biodiversity of the Central European farmland is to a large extent directly dependent on human management decisions. Diverse and dynamic biocoenoses have developed in mutual interactions with farming practices, and have been an integral part of agricultural land ever since the Neolithic. In the middle of the $20^{\text {th }}$ century, when synthetic biocides, mineral fertilisers and more powerful machinery became widely available, an unprecedented, steady and rapid erosion of farmland biodiversity commenced. Despite political declarations of intentions to slow biodiversity loss, pressure on farmland biodiversity has been further increasing in recent years. In the face of climate change and to reduce the dependency on limited fossil fuels, the subsidy-driven bioenergy boom is increasing the demand for arable land to cultivate the required feedstocks.

Only few scientific publications have yet addressed the consequences of the rapid expansion of energy cropping on farmland plant diversity. This thesis aimed to contribute to filling this gap, by recording the habitat conditions (field management, light regime, soil chemical properties) and the plant diversity in different energy cropping systems (maize for anaerobic digestion, oilseed rape for biodiesel and poplar/willow short rotation coppices (SRC) for wood chip combustion). Subsequently, the energy cropping systems were compared to conventionally managed food/fodder crops (wintersown wheat and barley) and to winter cereal fields managed extensively according to an agrienvironmental scheme (AES).

The results show clearly that the underlying root causes of the strong decline in arable plant diversity extent far beyond energy cropping. We found the arable plant assemblages in the field interior to be extremely impoverished in energy maize and oilseed rape fields as well as in conventionally managed winter-sown wheat or barley (on average 3-6 species $100 \mathrm{~m}^{-2}$ ). The mean nitrogen fertilisation rate $\left(195 \mathrm{~kg} \mathrm{~N} \mathrm{ha}^{-1} \mathrm{yr}^{-1}\right)$ and herbicide use intensity $(\mathrm{HI}=1.8)$ were shown to be similarly high for maize and winter wheat. Excessive phosphorus fertilisation (on average $96 \mathrm{~kg} \mathrm{P}_{2} \mathrm{O}_{5} \mathrm{ha}^{-1} \mathrm{yr}^{-1}$ ) was, however, discerned as a threat to plant diversity which mainly applies to maize production. Maize was also found to be more shading (11\% PAR transmissivity vs. 19\% in winter cereals) and consequently less species rich at the field margins than winter cereals (11 and 15 species $100 \mathrm{~m}^{-2}$ respectively). Across study regions, the arable plant communities of conventionally managed fields were typically dominated by the same set of only 5-10 common weedy species. We found (summer-sown) maize stands to offer habitats to a slightly different set of arable plant species than fields cultivated with winter-sown crops. A balanced mixture of maize, oilseed rape and winter cereals at the landscape scale consequently offers habitats to a wider range of arable plant species than any of these crops alone. Habitat conditions on extensively managed fields cultivated according to an AES were, however, found to be much more heterogeneous and suitable for a far greater range of species, including rare and threatened taxa (on average 21 species in the interior and 33 species $100 \mathrm{~m}^{-2}$ at the field margins). 
Our models also demonstrate that moderate reductions in herbicide use intensity or fertilisation while staying within the range of currently practiced conventional farming techniques can hardly be expected to reliably halt the decline in arable plant diversity. Novel, regionally adapted approaches and extensively managed arable habitats are urgently needed.

The plant diversity of SRC was found to decline strongly with plantation age. Young, low-input SRCs showed a community composition similar to early successional fallow land. Contrarily, 5-8 year old densely planted SRCs were found to be dominated by a set of few generalist, nitrophilous species. They were more shading (1-4\% PAR transmissivity) and only slightly more species rich (8-19 species $75 \mathrm{~m}^{-2}$ ) than annual energy crops, despite not being fertilised or treated with herbicides for several years. The planting of 5-20 m wide SRC strips dividing larger fields with annual crops, can nevertheless be recommended in structurally impoverished, intensively managed agricultural landscapes, particularly if measures to increase the variability of habitat conditions in the coppices are applied.

To address the root causes of plant diversity loss on farmland it seems, however, additionally paramount to create a permanent network of extensively managed field sanctuaries to maintain viable source populations which can potentially disperse to the wider agricultural landscapes in the future. To effectively inform policy makers, future research on energy cropping and farmland plant diversity should broaden the focus from the field to the landscape scale and address remaining open questions with regard to the interactions of arable plant diversity with other taxonomic groups. 


\section{Zusammenfassung}

Der große Artenreichtum der mitteleuropäischen Kulturlandschaften ist zu weiten Teilen unmittelbar von bestimmten extensiven Formen der Landbewirtschaftung abhängig. Vielfältige, artenreiche Biozönosen waren und sind ein wichtiger Bestandteil landwirtschaftlicher Nutzflächen. Sie haben sich seit dem Neolithikum im Wechselspiel mit den landwirtschaftlichen Wirtschaftsweisen kontinuierlich weiterentwickelt. Erst als synthetische Pflanzenschutzmittel, Mineraldünger und leistungsstarke Landmaschinen in der zweiten Hälfte des 20. Jahrhunderts weite Verbreitung erfuhren, setzte ein bis dato beispielloser, stetiger und schneller Rückgang der Artenvielfalt von Äckern, Wiesen und Weiden ein. Trotz politischer Absichtserklärungen den raschen Artenschwund zu stoppen, hat sich der Druck auf die verbleibenden Populationen auch in den letzten Jahren weiter erhöht. Der Klimawandel und der Wunsch die Abhängigkeit von endlichen fossilen Energieträgern zu reduzieren, haben dazu geführt, dass die Nachfrage nach Ackerland zum Anbau von Energiepflanzen, bedingt durch einschlägige Subventionen, stark gestiegen ist.

Nur wenige wissenschaftliche Publikationen haben sich bisher mit den Folgen der schnellen Ausweitung des Energiepflanzenanbaus Ackerflora beschäftigt. Diese Dissertation soll dazu beitragen, diese Lücke durch Untersuchungen der Habitatbedingungen (Bewirtschaftungsmethoden, Lichtklima im Bestand, Bodenchemie) und der Phytodiversität in verschiedenen Energiepflanzenbeständen (Silomais zur Biogaserzeugung, Winterraps zur Biodieselherstellung, Kurzumtriebsplantagen (KUP) aus Pappeln oder Weiden zur Hackschnitzelverbrennung) zu schließen. Die Energiepflanzenbestände wurden zudem mit konventionellem Wintergetreide zur Nahrungs- und Futtermittelproduktion (Winterweizen und -gerste) und mit extensiven Weizenbeständen aus Agrarumweltmaßnahmen (AUM) verglichen.

Die Untersuchungsergebnisse weisen eindeutig darauf hin, dass die eigentlichen Ursachen des starken Phytodiversitätsverlustes auf Äckern weiter reichen und grundlegender sind als der Anbau von Energiepflanzen. Es wurde gezeigt, dass die Phytozönosen im Inneren von Bioenergiemais- und Rapsäckern sowie auch in Wintergetreidebeständen extrem verarmt sind (im Mittel 3-6 Arten 100 $\mathrm{m}^{-2}$ ). Die durchschnittliche Stickstoffdüngung (195 $\mathrm{kg} \mathrm{N} \mathrm{ha}^{-1} \mathrm{a}^{-1}$ ) und der Herbizidbehandlungsindex $(\mathrm{HI}=1.8)$ waren sowohl in Mais- als auch in Winterweizenbeständen ähnlich hoch. Eine Bedrohung für die Pflanzenartenvielfalt durch übermäßige Phosphatdüngung (im Mittel $96 \mathrm{~kg} \mathrm{P}_{2} \mathrm{O}_{5} \mathrm{ha}^{-1} \mathrm{a}^{-1}$ ) wurde jedoch vor allem beim Maisanbau festgestellt. Zudem war die Beschattung in Maisbeständen erhöht (11\% PAR Transmissivität im Vergleich zu $19 \%$ in Wintergetreide), was mit einem Rückgang der mittleren Artenzahlen am Feldrand einherging (11 Arten $100 \mathrm{~m}^{-2}$ im Mais, 15 Arten $100 \mathrm{~m}^{-2}$ in Wintergetreide). Die Pflanzengesellschaften konventioneller Äcker wurden regionsübergreifend von nur 5-10 häufigen Problemunkrautarten dominiert. Maisbestände wiesen als Sommerkulturen eine von Winterkulturen leicht abweichende Artenzusammensetzung auf. Eine ausgeglichene Mischung von 
konventionellem Mais, Winterraps und Wintergetreide in der Agrarlandschaft bietet mehr Arten einen geeigneten Lebensraum als jede dieser Kulturen für sich genommen. Insgesamt waren die Habitatbedingungen auf den im Rahmen von AUM extensiv bewirtschafteten Äckern jedoch wesentlich heterogener und boten einer weitaus größeren Zahl von Pflanzenarten (darunter auch seltene und bedrohte Taxa) geeignete Lebensbedingungen. Im Mittel wurden 21 Arten $100 \mathrm{~m}^{-2} \mathrm{im}$ Inneren und 33 Arten am Feldrand gezählt. Auch die Regressionsmodelle weisen darauf hin, dass moderate Beschränkungen der Herbizidbehandlungsintensität oder der Düngung, die sich im Rahmen der zur Zeit üblichen konventionellen Bewirtschaftungspraktiken bewegen, kaum dazu beitragen den Rückgang der Ackerflora zu stoppen. Neue, an die jeweiligen regionalen Gegebenheiten angepasste Konzepte und extensive Ackerhabitate sind hierzu unerlässlich.

Die Vegetationsaufnahmen zeigen zudem, dass die Phytodiversität von KUP mit dem Alter der Plantagen stark zurückgeht. Junge KUP, ohne Düngung und mit nur geringem Herbizideinsatz, wiesen eine mit frühen Sukzessionsstadien von Ackerbrachen vergleichbare Artenzusammensetzung auf. Im Gegensatz hierzu wurden die 5-8 jährigen, dichtgepflanzten Plantagen von wenigen stickstoffliebenden Habitatgeneralisten dominiert. Obwohl sie seit mehreren Jahren weder gedüngt noch mit Herbiziden behandelt wurden, waren diese Bestände zudem dunkler (1-4 \% PAR Transmissivität) und nur wenig artenreicher (8-19 Arten $\left.75 \mathrm{~m}^{-2}\right)$ als einjährige Energiepflanzenkulturen. Die Pflanzung von 5-20 m breiten Energieholzstreifen zur Zerteilung großer Schläge in strukturarmen, landwirtschaftlichen Intensivregionen kann jedoch aus naturschutzfachlicher Sicht empfohlen werden, insbesondere wenn Maßnahmen nur Erhöhung der Habitatvielfalt in den Plantagen ergriffen werden.

Um die grundlegenden Ursachen des Pflanzenartenschwundes in Agrarlandschaften zu beheben, erscheint es jedoch darüber hinaus dringend notwendig, ein langfristig angelegtes Netzwerk extensiver Feldflorareservate zu begründen, um dauerhaft überlebensfähige Ackerwildkrautpopulationen zu erhalten und eine Ausbreitung dieser Arten in die weitere Agrarlandschaft in Zukunft wieder zu ermöglichen. Um politische Entscheidungsfindungen zu unterstützen, erscheint es notwendig im Rahmen von zukünftigen Forschungsprojekten den Blickwinkel vom Feld auf die Landschaftsebene zu erweitern und verbleibende offene Fragen über die Wirkungen der Ackerflora auf andere taxonomischen Gruppen zu klären. 


\section{Chapter 1}

\section{Introduction}

\subsection{Research context}

\subsubsection{Plant diversity in agricultural landscapes}

\subsubsection{Arable plant assemblages as a mirror of agricultural land use practices}

The European landscape of today is the result of the long-term regional climate history and millennia of human interference (Lang et al., 2003; Behre, 2008). Without human influence the largest part of Europe, in particular of Central Europe, would today be covered by forests (Bohn et al., 2000/2003; Ellenberg \& Leuschner, 2010). Since human settlements became common in the Neolithic, forests were increasingly used as wood pastures, cleared for crop production and logged to meet the growing demand for fire wood and construction material (Lang et al., 2003). The intensity of this process showed strong spatial and temporal variations and fluctuations (Lang et al., 2003; Behre, 2008). It resulted in dynamic mosaic landscapes with a mixture of non-forested and forested habitats and led to the development of the species-rich biocoenoses of open habitats which we know today.

The farmland flora, i.e. the flora of (fallow) arable land, pastures and meadows, evolved alongside the development of new farming techniques since the Neolithic (Willerding, 1986; Pott, 1992; Hofmeister \& Garve, 2006; Ellenberg \& Leuschner, 2010). During the Neolithic, crop production was commonly interrupted by long-term fallow periods. Consequently, the respective plant communities were found to be dominated by perennial species (Willerding, 1986; Pott, 1992). The differentiation between arable plant communities, dominated by annual plant species and grassland communities dominated by perennials became increasingly clear since medieval times, when fallow periods became shorter and less common (Willerding, 1986). A more detailed account of the main agricultural developments in the study areas and the impacts on arable plant diversity is given in section 1.2.2.

Genotypes allowing for a high degree of phenotypic plasticity are typically most successful in arable habitats (Imam \& Allard, 1965; Hermanutz \& Weaver, 1996). Other favourable properties include the production of large quantities of seeds, the ability to easily disperse over large distances, a resistant 
seed coat, heterocarpy, the rapid completion of the life cycle, the long-term maintenance of germinability and/or the presence of underground storage organs which survive regular anthropogenic soil disturbances (Hofmeister \& Garve, 2006).

Many of the farmland species (the so called archaeophytes) were introduced from the steppic habitats of the Middle East or the Mediterranean to the Central European agricultural habitats (Fig. 1.1; Ellenberg \& Leuschner, 2010). Another group of species originates from naturally open habitats such as open shores and natural forest clearings and is considered native to Central Europe (Schneider et al., 1994). Some arable plant species such as common corncockle (Agrostemma githago), whiskered brome (Bromus grossus) and flax dodder (Cuscuta epilinum) are today completely dependent on the arable habitats in which they have evolved. There are no or hardly any known populations of these species in natural habitats which could provide the necessary conditions to serve as sanctuaries for their conservation. Historically, seeds of A. githago were harvested and re-sown together with the grain. Since seed cleaning techniques reliably discard corncockle seeds from the harvested grain, the species suffered strong declines and is nowadays threatened with extinction (Ludwig \& Schnittler, 1996). B. grossus is also critically endangered (Ludwig \& Schnittler, 1996) and listed in Annex II of the EU habitats directive, due to the loss of extensively managed spelt fields. As a consequence of the cessation of flax cultivation, C. epilinum is nowadays extinct in Germany (Ludwig \& Schnittler, 1996). As shown above, the arable flora often directly reflects field management practices and can therefore be regarded as a mirror of the human land use history and as an important and integral part of the European nature and culture.
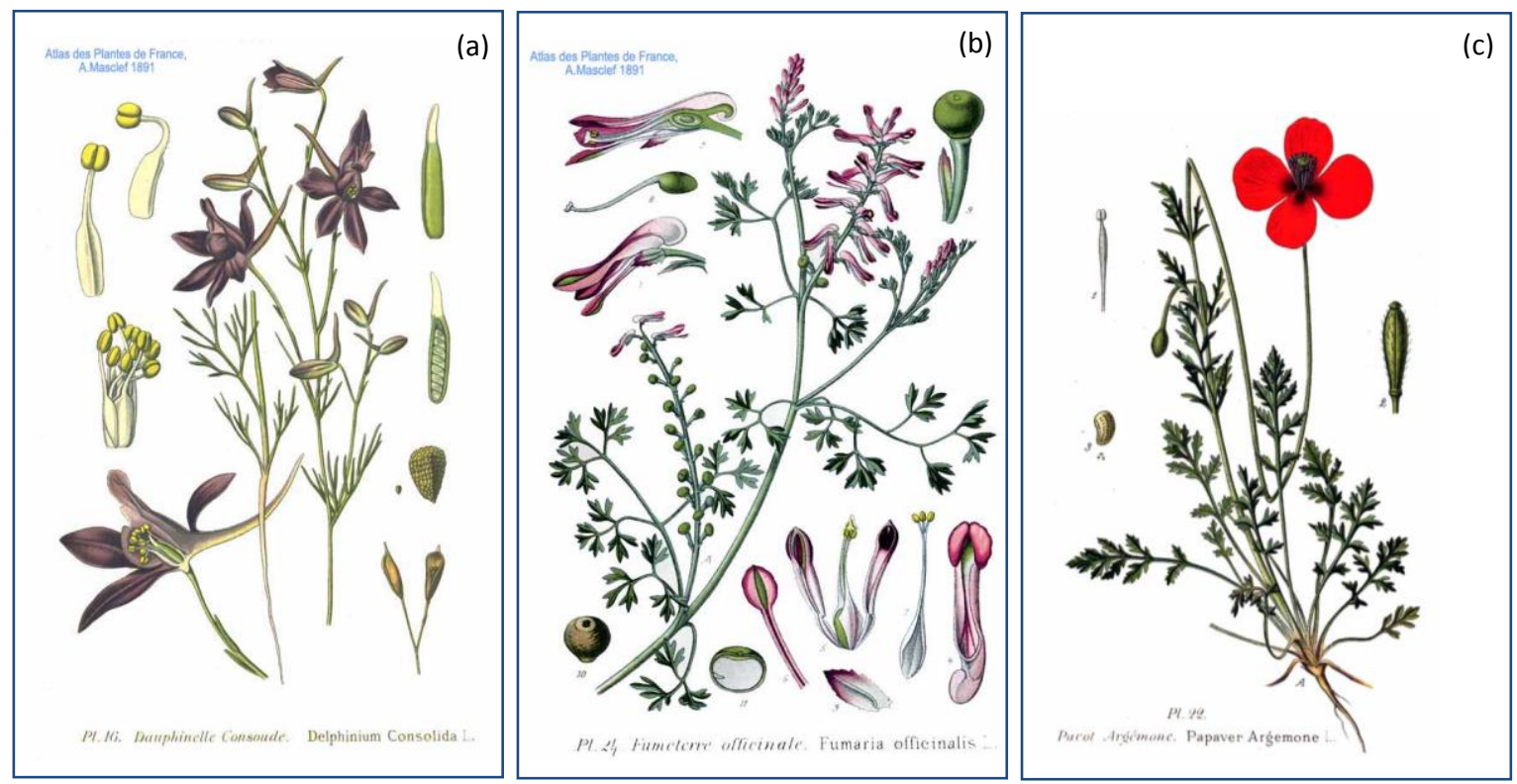

Fig. 1.1 Examples of arable archaeophytes (a) field larkspur Consolida regalis, (b) common fumitory Fumaria officinalis and (c) pale poppy Papaver argemone. All drawings are from the Atlas des Plantes de France by Amédée Masclef (1891). 


\subsubsection{The role of arable plants in agroecosystems}

Besides their role as crop competitors, arable plant species fulfil a diverse set of ecological functions in agro-ecosystems. The concept of arable plants as being merely detrimental is therefore gradually being replaced by a more integrated view which values the ecological benefits arising from diverse arable plant assemblages.

Being the basis of the farmland food web, arable plants provide important resources for herbivores and decomposers (Parish et al., 2009). Concomitantly, this affects the predators of higher trophic levels. Today far less than $1 \%$ of the total summer biomass of high-input arable fields consists of non-crop arable plants (Parish et al., 2009). Research shows that the rapid and ongoing decline in farmland bird species is partly due to the lack of feeding resources (i.e. seeds and arthropods) in impoverished, highinput cropping systems (Marshall et al., 2003; Taylor et al., 2006; Evans et al., 2011). It has also been shown that more diverse arable plant communities are less suitable for mass reproductions of herbivorous crop pests (Altieri, 1999). This has been linked to the increased presence of antagonistic pest predators which find better habitat conditions in more diverse fields (Altieri, 1999; Jordan \& Vatovec, 2004; Evans et al., 2011). Diverse arable plant communities, furthermore, contribute to the maintenance of favourable levels of plant-pollinator interactions in agricultural landscapes (Gabriel \& Tscharntke, 2007).

Jordan \& Vatovec (2004) highlight that the arable flora can contribute to reducing soil erosion, slowing nutrient loss, increasing soil organic matter, improving nitrogen levels and conserving soil water. Additionally, positive effects on decomposer communities have been observed as the colonization of bare soil by arable plants typically leads to an increase in soil microbial biomass and soil arthropods (Wardle, 1992, 1995).

These examples show that arable non-crop plants, in addition to serving as a source of joy and beauty to passers-by and as allegory and inspiration to poets and painters, are a vital key element of agricultural ecosystems. Maintaining tolerable levels of arable plants in agricultural landscapes would consequently not only contribute to the protection of a highly specialised and highly threatened group of species, but it would positively affect many other taxa and ecosystem processes.

\subsubsection{Current conservation status}

The current conservation status of arable plants is distressing particularly in northern and western Europe, due the negative impacts of the intensification of land use (i.e. increased fertilisation and herbicide use, narrow crop rotations, very effective seed cleaning techniques and increasingly homogeneous agricultural landscapes; Sutcliffe \& Kay, 2000; Fried et al., 2009; Storkey et al., 2012). The species richness and abundance of arable non-crop species has been severely reduced since the 
1950s in many western European countries (Sutcliffe \& Kay, 2000; Fried et al., 2009; Kohlbrecher et al., 2012; Meyer et al., 2013). A study from Central Germany showed reductions of the regional species pool of 23\%, translating into the loss of 68 out of 301 recorded arable plant species (Meyer et al., 2013). In Germany, there are approximately 300 specialised arable plant species of which > 55\% are categorised as threatened in at least one federal state (Hofmeister \& Garve, 2006). 71 taxa (> 20\%) are even threatened at the national level (Fig. 1.2; Ludwig \& Schnittler, 1996; Hofmeister \& Garve, 2006). Field margins are often the last refuges for the remaining arable plants (Marshall \& Moonen, 2002; Fried et al., 2009). In the field interior, the arable flora is commonly reduced to a set of 5-10 common, weedy plant species which can resist herbicide applications and are able to compete with the crop on highly fertilised soils (Meyer et al., 2013). As the field interior of conventionally managed fields is no longer suitable as habitat for most arable plant species, and increases in field size dwarfed the amount of land allotted to the field margins, the available habitat for arable plant species has been reduced by $95 \%$ in Northern Germany since the 1950s (Hötker \& Leuschner, 2014).
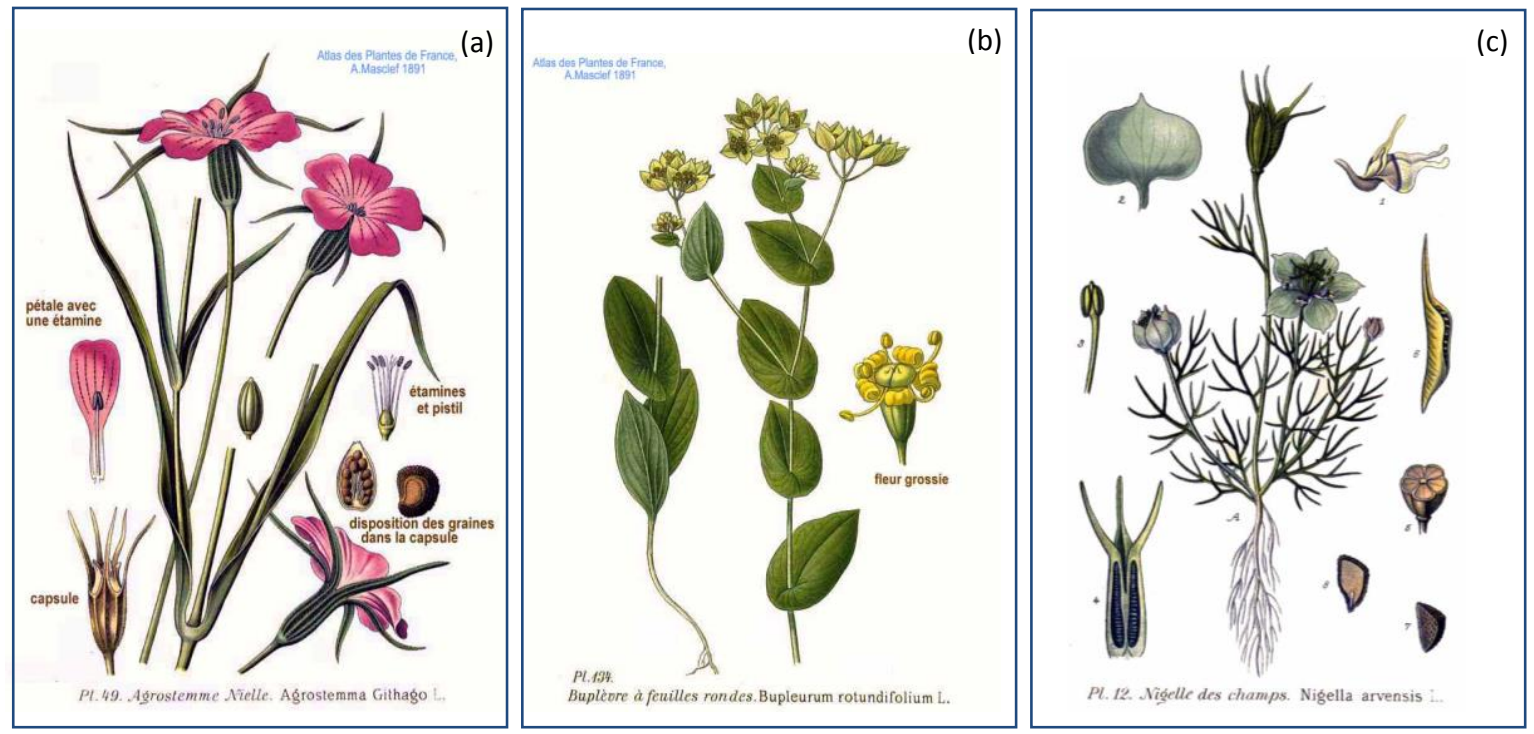

Fig. 1.2 Examples of nationally endangered arable plant species (a) common corncockle Agrostemma githago (critically endangered, category 1) (b) hare's ear Bupleurum rotundifolium (critically endangered, category 1) and (c) black bread weed Nigella arvensis (endangered, category 2) (Ludwig \& Schnittler, 1996). All drawings are from the Atlas des Plantes de France by Amédée Masclef (1891).

As shown above, arable plant communities, which are the result of several thousand years of evolution alongside humans, are severely endangered. Concepts for halting the erosion of the biodiversity of agricultural ecosystems are currently not receiving the necessary political and financial support to be effective (Hötker \& Leuschner, 2014). Changes in agricultural practices which potentially further increase the pressure on arable plant communities can make the recovery of a diverse and dynamic arable flora even more difficult in the future. It is therefore of particular importance to fully assess the impacts of any large scale changes in agricultural land use practices on arable plant diversity. 


\subsubsection{Energy cropping}

\subsubsection{Contribution to the total energy supply}

\section{Global importance of bioenergy}

Currently, approximately $10 \%\left(=52 \mathrm{EJyr}^{-1}\right)$ of the world's primary energy supply is covered by biomass (Fig. 1.3; Vakkilainen et al., 2013). Biomass can be used to produce thermal energy, electricity and transport fuels. With a share of approximately $90 \%$ of the global bioenergy production, woody biomass is the most important bioenergy feedstock (Nemestóthy, 2012). Although the global biomass trade is growing rapidly, it only made up about $5 \%$ of the total use of biomass for energy in 2011 (excluding intra EU trade; Vakkilainen et al., 2013). The direct trade represented $0.5 \mathrm{EJyr}^{-1}$ in 2011 (including wood pellets, biodiesel, palm oil, ethanol, fuel wood and charcoal) and the indirect trade, i.e. energy production from residues of wood which had primarily been imported to be used as raw material, represented 0.6 $\mathrm{EJyr}^{-1}$ (Vakkilainen et al., 2013). The domestic and the intra EU biomass production is therefore of great importance with regard to the environmental impacts of the sector in Europe.

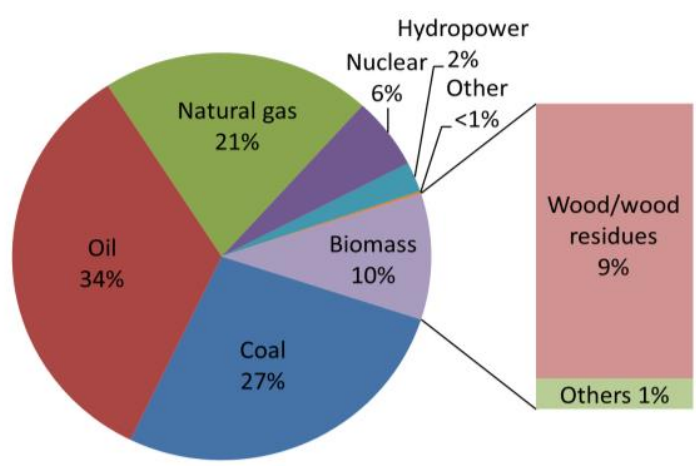

Fig. 1.3 Contribution of bioenergy to the global primary energy consumption of approximately $510 \mathrm{EJyr}^{-1}$. Based on data from Vakkilainen et al. (2013) and Nemestóthy (2012).

\section{Bioenergy in the European Union}

In the European Union (EU-27) $4.3 \mathrm{EJyr}^{-1}$, equalling approximately 6\% of the total primary energy consumption, were produced from biomass in 2010 (EEA, 2012, 2013b). The demand for bioenergy is estimated to more than double to $10.0 \mathrm{EJyr}^{-1}$ by 2020 to comply with the targets of the national renewable energy action plans of the EU member states (Bentsen \& Felby, 2012). Currently, approximately $76 \%$ of the bioenergy is produced from woody material (wood and wood residues), whereas $24 \%$ is based on energy cropping in an agricultural context and the processing of animal manures (Fig. 1.4; EEA, 2013b). In 2008, most energy crops grown on EU farmland were annual food and fodder crops such as oilseed rape (59\%), sun flower (20\%), cereals (11\%) and maize (7\%) (EEA, 2013a). Germany and France were the main producers of energy crops with 1.53 and 1.35 million ha 
respectively, followed by Poland and Romania with 0.76 and 0.57 million ha (Panoutsou et al., 2011). Since 2008 the sector has developed rapidly, but more recent figures at a European scale are surprisingly not available (Don et al., 2012). The recent literature shows, however, that the general picture has changed only little. Annual energy crops are still predominant and perennial energy crops, such as short rotation coppices, are not yet grown at large scales across the EU (Don et al., 2012).

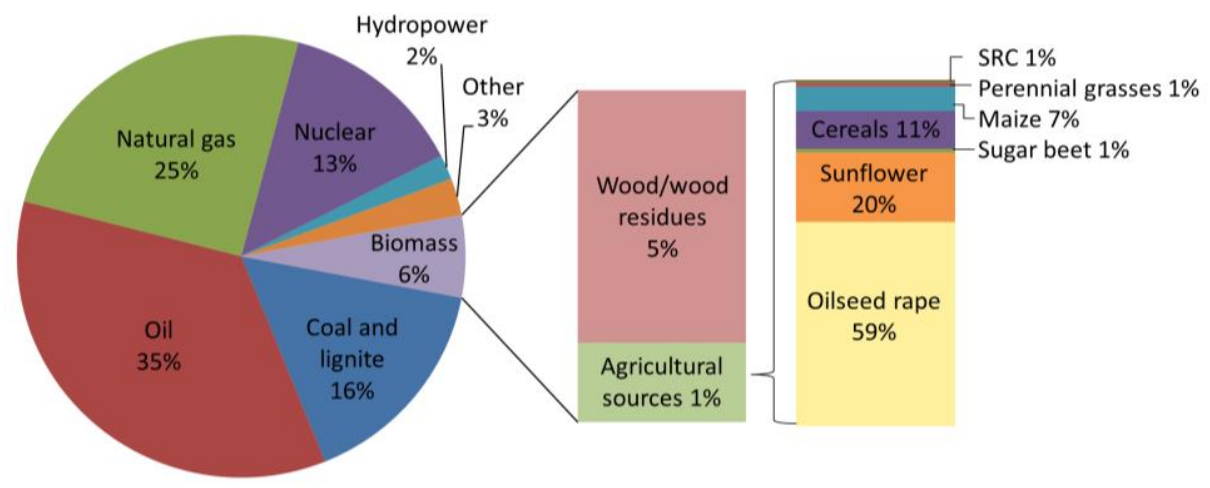

Fig. 1.4 Contribution of bioenergy to the primary energy consumption of the EU (EU27 ) in 2010 (in total approximately $72 \mathrm{EJyr}^{-1}$ ) and contribution of different crops to the renewable energy mix (based on 2006-2008 data). No data on the contribution of animal manures to energy production from agricultural sources in the EU were available. Animal manures are therefore no represented in this figure, although they are subsumed under "agricultural sources". SRC $=$ Short rotation coppice. Adapted from EEA (2013a \& 2013b).

\section{The case of Germany - 'Energiewende'}

Germany, currently the largest producer of energy crops in the EU (Don et al., 2012), is pursuing an ambitious agenda for the transition from fossil to renewable energies, the so called 'Energiewende' (BMU \& BMELV, 2010). In 2012, 8.2\% (equalling 734 PJ) of the final energy consumption was covered by biomass (Fig. 1.5; FNR, 2013a). Biomass for heating (mostly solid fuels) represented approximately $59 \%$, biomass for power generation $24 \%$ and for transport fuels $17 \%$ of this fraction (FNR, 2014b). This means that $9.2 \%$ of the heating, $7.5 \%$ of the power generation, and $5.7 \%$ of the transport fuels in Germany were produced from biomass (FNR, 2013e, 2014a, 2014d). Projections for 2020 expect an increase of these fractions to $9.7 \%$ for heat, $8.0 \%$ for power and $12.0 \%$ for transport fuels (BMU \& BMELV, 2010). With the exception of transport fuels these targets are likely to be reached well before 2020 .

Solid fuels (mostly wood and wood residues) are the most important biomass resource and the source of $81 \%$ of the thermal energy and $31 \%$ of the power generation from biomass in Germany (Fig. 1.5; 
(FNR, 2013k, 2014d). The contribution of solid biofuels from agricultural sources, such as short rotation coppices or crop residues, to the national energy supply remains low (see section 1.1.2.2.).

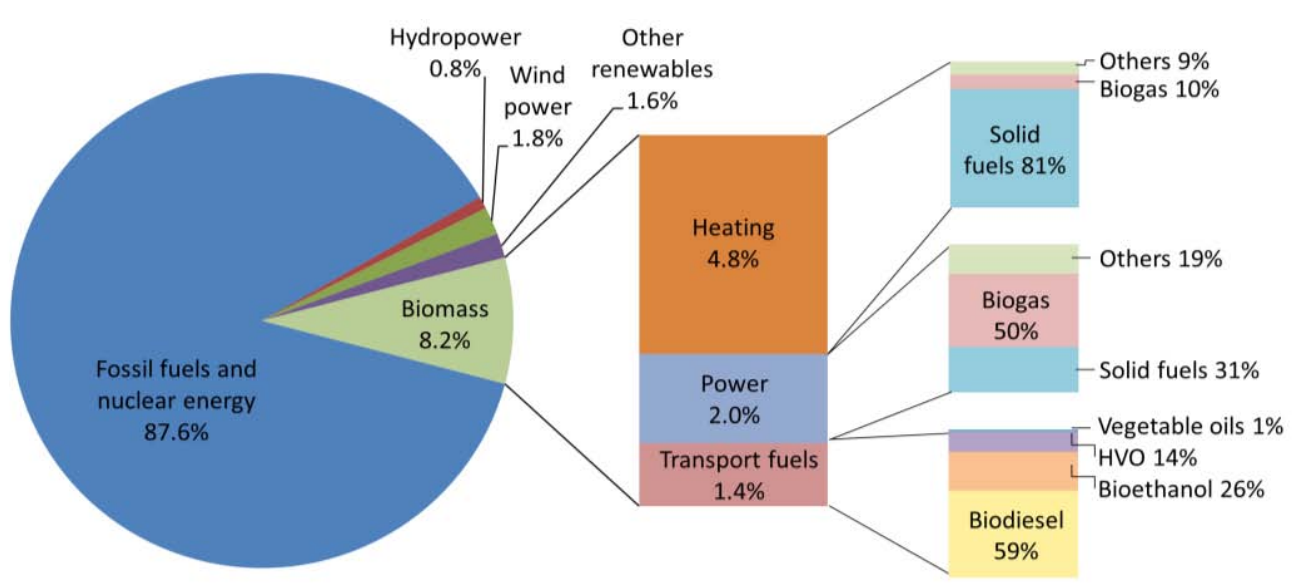

Fig. 1.5 Contribution of bioenergy to the final energy consumption in Germany in 2012 (approximately $9.0 \mathrm{EJyr}^{-1}$ ) according to the type of energy and the type of fuel. HVO = Hydrogenated vegetable oils. Adapted from FNR (2012, 2013a, 2013k, 20131, 2014b, 2014d).

Unlike other EU countries, Germany strongly supports the establishment of farm-based plants for anaerobic digestion (also called 'biogas plants') through national subsidies (BMU \& BMELV, 2010) and consequently has the largest biogas sector (Don et al., 2012). Biogas plants produce $50 \%$ of the power and approximately $10 \%$ of the heat generated from biomass in Germany (Fig. 1.5, (FNR, $2013 \mathrm{k}, 20131,2014 \mathrm{~d})$. These fractions sum up to $1.3 \%$ of the final energy consumption or approximately $3.8 \%$ of the total power generation and $1 \%$ of the total heat production (FNR, 2013a, $2013 \mathrm{k}, 2014 \mathrm{a}$ ). The contribution of purified biogas (bio methane) to the consumption of transport fuels in Germany is with approximately $0.06 \%$ only marginal (FNR, 2012, 2013e).

Germany is also the largest producer of biodiesel and the second largest producer of bioethanol in the EU (Don et al., 2012). Biodiesel accounted for 3.4\% of the national transport fuel consumption in 2012 and bioethanol covered $1.5 \%$ (FNR, 2013e).

\subsubsection{Conversion technologies and biomass feedstocks}

\section{Solid biofuels}

Solid biofuels can be used to produce heat, power and even transport fuels either through combustion (directly or by thermo-chemical conversion to charcoal) or via gasification (Kappas, 2013; FNR, 2014c). Detailed descriptions of the different combustion and gasification technologies are 
available from Luque et al. (2011) and a good summary on the subject can be found in FNR (2014c). Wood and wood residues from forestry have by far the greatest share of all solid biofuels in Germany and worldwide (FNR, 2014c). As forest resources are limited (Verkerk et al., 2011), the importance of solid biofuels produced on farmland is starting to increase. All crops and crop residues can theoretically be used as solid biofuels after the appropriate pre-processing (i.e. sizing, drying and/or densification of the material). Examples include short rotation coppices (SRC; i.e. fast growing trees such as poplar or willow grown on farmland), cereals (the whole plant, the straw or the grain), miscanthus (Miscanthus $\times$ giganteus) and biomass from permanent grasslands and leys. Solid biofuels were grown on only 11,000 ha farmland in 2013 in Germany, i.e. approximately $0.07 \%$ of the agriculturally used area (Fig. 1.6; FNR, 2013c). Estimates suggest that short rotation coppices currently cover between 6,000 $-10,000$ ha (Hagemann et al., 2013). Miscanthus was grown on approximately 3,000 ha in 2011 (Pude, 2012). Both crops are estimated to yield about $50-300 \mathrm{GJha}^{-}$ ${ }^{1} \mathrm{yr}^{-1}$ depending on the conversion technology, the site conditions and the field management (SRU, 2007; FNR, 2014c). Due to these high energy yield potentials, which can compete with anaerobic digestion of maize silage (50 - $200 \mathrm{GJha}^{-1} \mathrm{yr}^{-1}$; SRU, 2007; Grassini \& Cassman, 2012), SRC and miscanthus are potentially economically and ecologically interesting options for the bioenergy sector. This is one reason why the area cultivated with SRC and miscanthus is expected to expand substantially during the next decade. Aust (2012) found a realizable potential of approximately 0.7 million ha (or $145 \mathrm{PJyr}^{-1}$ ) for the cultivation of SRC in Germany. The FNR (2014c) estimated a potential for energy production from solid biofuels grown on arable land of $180 \mathrm{PJ}$ for the year 2007 and an increase up to $>700 \mathrm{PJyr}^{-1}$ by 2020 . Surprisingly, no data on the currently realised energy production from solid biofuels from agricultural systems is available, but with regard to the small area cultivated with SRC and miscanthus it is bound to be much less than the estimated potentials (in the range of $\left.1-3 \mathrm{PJyr}^{-1}\right)(\mathrm{SRU}, 2007$; FNR, 2014c).

\section{Biomass for anaerobic digestion}

Biogas is produced in a bio-chemical conversion process through anaerobic digestion (Kappas, 2013). Biogas plants can use a variety of feedstocks, as long as these have a high content of crude proteins and crude fats, and a low content of dry matter and lignocellulosic compounds (Amon et al., 2007a; Amon et al., 2007b). Methane $\left(\mathrm{CH}_{4}\right)$ is the main combustible compound of biogas making up between $50-75 \%$ of the gas mixture (FNR, 2013b). A comprehensive description of the technical installations, the bio-chemical process and the suitability of different substrates for anaerobic digestion can be found in FNR (2013b) and Luque et al. (2011). German biogas plants are currently run on animal manures (41\%) and silage from energy crops such as maize (40\%), grass $(6 \%)$ and cereals (4\%) (FNR, 2013g, 2013h). Maize is the preferred energy crop as it produces the highest biomass and methane yields per hectare and can be cultivated with readily available machinery (Amon et al., 
2007a; Boehmel et al., 2008). Maize for biogas production is currently grown on 0.8 million ha (about $7 \%$ of the arable land) and represents $32 \%$ of the total maize production in Germany (FNR, 2013f; Destatis, 2014). The area cultivated with energy maize has thus more than tripled since 2007 (FNR, 2013d) and is expected to keep expanding rapidly during the next decade (BMU \& BMELV, 2010). The area cultivated with alternative biogas feedstocks, e.g. silage from cereals, sugar beet, sorghum, sunflower, cup plant, clover leys and grassland biomass as well as wild flower mixtures is with 0.35 million ha much smaller (FNR, 2013c, 2013f). No current data on the exact area of each of these alternative feedstocks are available for Germany.

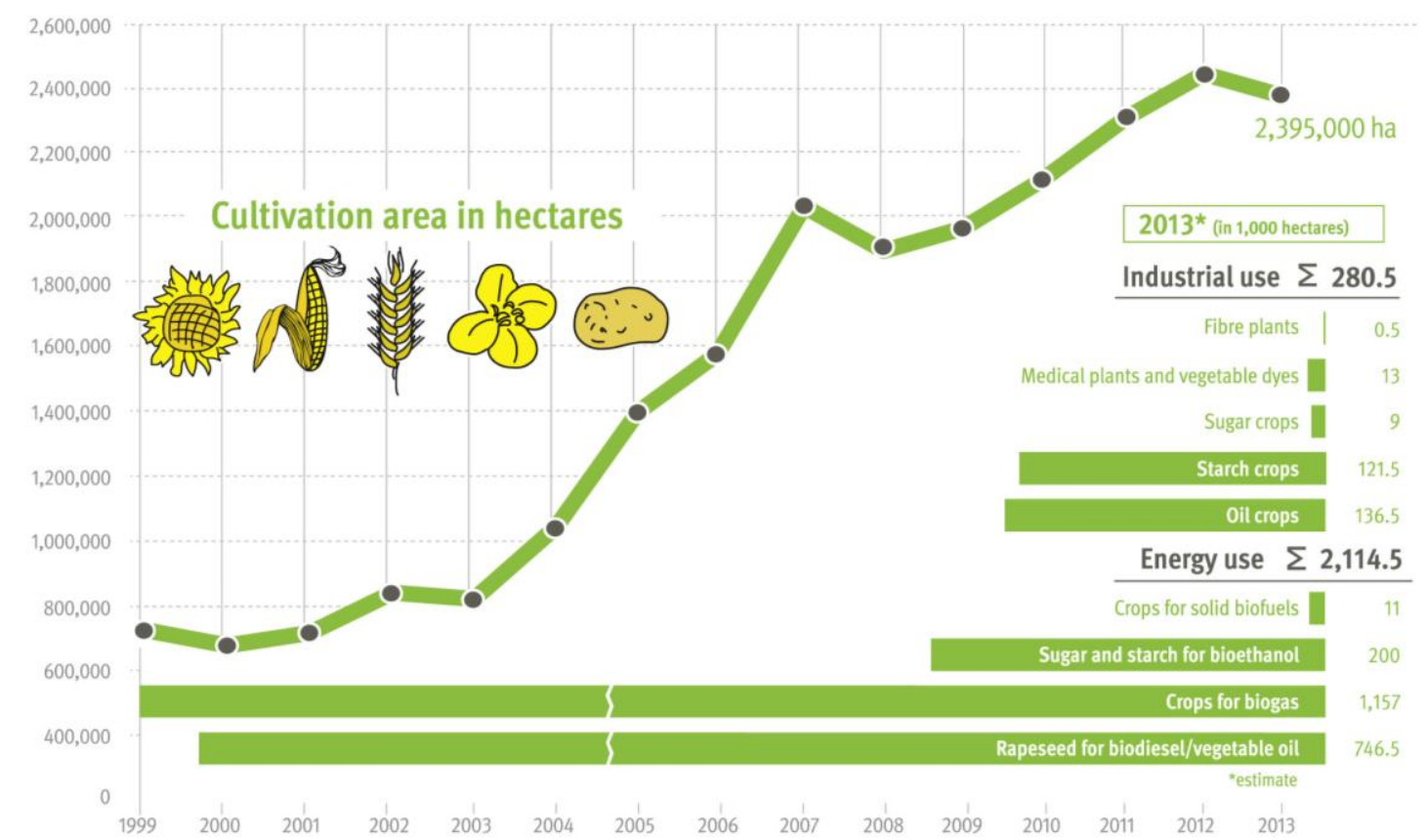

Fig. 1.6 Area used for the cultivation of renewable resources in Germany (19992013). Adapted from FNR (2013c).

\section{Biomass for liquid transport fuels}

Technically, there is a range of liquid biofuels for transport available, including among others biodiesel, vegetable oils, bioethanol, hydrogenated vegetable oils (HVO), biobutanol, and biomass to liquid fuels (BtL) (Schmitz et al., 2009). Only the first four of these options are currently available on the German market with biodiesel accounting for approximately 59\%, bioethanol for $26 \%$, HVO for $14 \%$ and vegetable oil for $1 \%$ of the German biofuel consumption (Fig. 1.5; FNR, 2012). The substrate requirements differ between the different kinds of transport biofuels. For a detailed description of the conversion processes refer to Luque et al. (2011).

Oilseed rape is, with a share of $85 \%$, the most important resource for biodiesel production in Germany, followed by waste fats (10\%), palm oil (2\%) and soy (3\%) (FNR, 2013j). Oilseed rape for 
biodiesel and (hydrogenated) vegetable oil production was grown on 0.79 million ha equalling approximately 7\% of the arable land in Germany in 2012 (FNR, 2013c; Destatis, 2014). This means that about $60 \%$ of the total rapeseed acreage in Germany was used for biofuel production (BLE, 2013). The total area grown with oilseed rape increased between 2000 and 2012 from 1.08 million ha to 1.30 million ha (BLE, 2013) due to high commodity prices. This overall increase was steady but with minor fluctuations until 2007 (BLE, 2013). Since 2007 no further increase of the rapeseed acreage was observed (BLE, 2013). As opposed to maize, oilseed rape reacts to continuous cropping in monoculture with strong yield declines of up to $25 \%$ (Hilton et al., 2013). To avoid yield declines oilseed rape can only be grown every third to fourth year at the same site, which generally restrains the expansion (Hilton et al., 2013). Alternative oil crops such as sunflowers or flax are not used for biodiesel production to any significant extent in Germany.

Plants for bioethanol production, such as sugar beet or cereals, were grown on 0.2 million ha in 2012 and 2013 (FNR, 2013c).

\subsubsection{Environmental impacts of energy cropping}

As shown in the previous section the production of biomass as a renewable energy source affects large proportions of land. It can lead to substantial changes in the kind and intensity of land use and land management. The environmental impacts of energy cropping, i.e. the impacts on biodiversity, greenhouse gas emissions, nutrient and water cycles, differ between energy cropping systems. When assessing the impacts of energy cropping the baseline, i.e. the former land use against which the energy crop is compared, is of fundamental importance (St. Clair et al., 2008; Immerzeel et al., 2014). Impacts can furthermore either be direct, i.e. caused at the site by the cultivation of the specific energy crop in comparison to the previous land use or indirect, i.e. caused by changes in land use elsewhere which were induced by the displacement of the kind of land use which is being replaced by energy cropping (Fargione et al., 2008; Lapola et al., 2010; Immerzeel et al., 2014). This work mainly deals with the direct impacts of energy cropping. As the indirect impacts are nevertheless of great importance to fully understand the consequences of energy cropping, they are also shortly discussed afterwards.

\section{Direct impacts on biodiversity}

A large body of research shows that the biodiversity of agricultural landscapes generally benefits from a heterogeneous landscape structure creating a mosaic of different habitats (Benton et al., 2003; Tscharntke et al., 2005). Another essential requirement is the availability of sufficient land with conditions suitable for reproduction and survival (Benton et al., 2003; Tscharntke et al., 2005). 
Many farmland species are dependent on the presence of low-input grasslands, croplands and fallow lands (Wesche et al., 2012; Meyer et al., 2013).

The increasing demand for land to produce feedstocks for bioenergy production is affecting farmers' land use decisions, which in turn can affect the biodiversity of agricultural landscapes (Dauber et al., 2010; Immerzeel et al., 2014). The effects of bioenergy feedstocks on biodiversity differ widely depending on the type and intensity of land management required for its production and the type of land use which is being replaced (Immerzeel et al., 2014). In comparison with annual energy crops and/or other conventionally managed, high-input cropping systems, perennial 'second-generation' energy crops, such as SRC or miscanthus, are typically expected to have positive effects on biodiversity (Dauber et al., 2010; Immerzeel et al., 2014). When compared to grasslands, fallow land, low-input cropland or forests the effects are less clear and the impacts on biodiversity will often be neutral or negative (Immerzeel et al., 2014; Meyer et al., 2014).

As the pressure on agricultural biodiversity is already extremely high (cp. section 1.1.1.3), the conversion of species rich agricultural habitats such as fallows or grasslands to energy croplands is of particular concern (Glemnitz et al., 2008). The strong decline in fallow land (set-aside) since the year 2000 is at least partially due to the increased demand for land for bioenergy production (NABU, 2007; Glemnitz et al., 2008). Since 1992 and until 2007, farmers were required to take a certain amount (initially $15 \%$, later 10\%, then 5\% and from 2007 onwards $0 \%$ ) of their acreage out of production, to reduce grain surpluses and stabilise global food market prices. Biodiversity, and arable plant diversity in particular, typically greatly benefited from this set-aside requirement (Tscharntke et al., 2011). The production of renewable resources, such as bioenergy feedstocks was, however, allowed on the setaside land, reducing its value for biodiversity conservation. This option was increasingly used since governmental subsidies additionally supported the production of renewable resources and the establishment of farm-based plants for anaerobic digestion throughout Germany (NABU, 2007). Demand for land for bioenergy production (in conjunction with increasing global demands for agricultural products), finally led to the complete abolishment of the European set-aside requirement in 2009 with severe negative impacts for the agricultural biodiversity. In 2013 only 200,000 ha of fallow arable land (i.e. less than $1.7 \%$ of the arable land) were left in Germany, representing a reduction by approximately 70\% since 2007 (Destatis, 2007; NABU, 2007; Destatis, 2014). Fallow land is today no longer widely available as a refuge for agricultural biodiversity.

Another important issue is the loss of permanent grassland observed throughout Germany in recent years (BfN, 2014). Grassland is increasingly being abandoned or converted to cropland as its economic profitability is decreasing, due to changes in the structure of livestock production, strong subsidies for energy feedstocks and high commodity prices for cereals and other crops (Nitsch et al., 2012; BfN, 2014; Laggner et al., 2014). Since 1990, the grassland area in Germany decreased by > 
0.88 million ha to about 4.6 million ha in 2013 (BfN, 2014). Although the direct and indirect impacts of energy cropping on the conversion of species rich grasslands are hard to quantify, it has been shown that the probability of grassland conversion increases in the vicinity of biogas plants (Laggner et al., 2014). The habitat quality of the remaining grassland also decreased drastically as intensification progressed (BfN, 2014). As biomass from highly fertilised grasslands with a high cutting frequency is better suitable as substrate for anaerobic digestion than biomass from extensively managed grasslands, the use of grassland biomass as a biogas feedstock can additionally incentivise grassland intensification (Ortloff, 2012). Biomass from extensively managed grasslands has a higher content of lignocellulosic compounds and is therefore better suitable for combustion instead of anaerobic digestion (Ortloff, 2012).

On the other hand, it has also been shown, that the majority of the bioenergy feedstocks are grown on former arable land (Laggner et al., 2014) leading to shifts in crop rotations and changes in crop frequencies at the landscape scale (Steinmann \& Dobers, 2013). The impacts of the expansion of energy cropping on arable land are therefore in the focus of the research presented in this thesis. Two issues are of particular importance with regard to the impacts of energy cropping on the biodiversity of arable land: (a) changes in field management on conventionally managed arable land and (b) the intensification of land use, i.e. the loss of extensively managed, low-input cropland. The consequences of both issues have been addressed in the present work.

The direct impacts of 'first generation', annual energy crops on biodiversity have only rarely been addressed by research (Immerzeel et al., 2014; Meyer et al., 2014), although they dominate the energy cropping sector in Europe (EEA, 2013a). The available results indicate that effects differ strongly between different targeted taxa. Skylarks (Alauda arvensis) have been shown to be particularly negatively affected by maize cultivation (Nagy et al., 2009; Gevers et al., 2011; Everaars et al., 2014; Sauerbrei et al., 2014), whereas a carabid beetle and a linyphiid spider were found to benefit (Gevers et al., 2011). The status of the arable flora in annual energy cropping systems has yet received little attention. Available results show negative effects of maize cropping on arable plant diversity (Glemnitz et al., 2008; Waldhardt et al., 2011; Meyer et al., 2014).

\section{Direct impacts on the abiotic environment and soil organic matter cycles}

Apart from the impacts on biodiversity, energy cropping also affects land based greenhouse gas (GHG) emissions, nutrient and water cycles. Estimates of the contribution of bioenergy to the reduction of GHG emissions to mitigate climate change differ widely depending on the feedstocks, the conversion technologies and the parameter setting of the respective model (Cherubini \& Strømman, 2011). Although the majority of the scientific assessments found net reductions of GHG emissions 
when bioenergy replaces fossil fuels, significant uncertainties remain, particularly with regard to the impact of land use change and land management change (Cherubini \& Strømman, 2011). According to the FNR (2013i), the use of bioenergy in Germany led to a reduction of GHG emissions of 70.8 million $\mathrm{t} \mathrm{CO}_{2}$-equivalents $\left(\mathrm{CO}_{2} \mathrm{e}\right)$ in 2012 . This is a considerable amount equalling $7.5 \%$ of the total German GHG emissions of 940 million $\mathrm{C} \mathrm{CO}_{2} \mathrm{e}$ in 2012 (UBA, 2014). No information is available to which extent land use change (i.e. GHG emissions from the conversion of permanent grassland to arable land) and changes in the intensity of land management (resumption of high-input production on former fallow land) were incorporated in this evaluation.

Despite these uncertainties, general patterns with regard to the GHG balance of particular bioenergy feedstocks and conversion technologies have been observed. Firstly, the net GHG reductions from transport biofuels are generally lower than the reductions due to heat and power generation from biomass (Rowe et al., 2009; Cherubini \& Strømman, 2011). In Germany, transport biofuels were

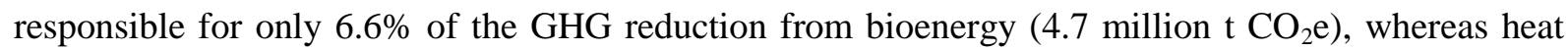
accounted for $53.6 \%$ and power generation for 39.7\% (FNR, 2013i). Secondly, 'second generation' energy crops, i.e. perennial crops such as SRC or miscanthus, which are not used for food and/or fodder production, have been found to contribute more strongly to GHG reductions than 'first generation' annual energy crops such as maize or oilseed rape (Rowe et al., 2009; Cherubini \& Strømman, 2011; Havlík et al., 2011). Thirdly, energy cropping on former arable land will have a more positive effect on the GHG balance than energy cropping which involves the conversion of grassland or forest (St. Clair et al., 2008; Rowe et al., 2009). Pre-harvest GHG emissions from oilseed rape production have been found to greatly exceed emissions from intensively managed grasslands and to be similar to emissions from cereal cropping (St. Clair et al., 2008). GHG emissions from lowinput SRC and miscanthus can on the other hand be equal or even lower than emissions from intensively managed grasslands (St. Clair et al., 2008).

Energy cropping also affects soil carbon cycles. The soil organic matter (SOM) balance largely depends on the kind of energy crop, the local soil and climate conditions, the soil cover and the frequency and depth of tillage. Maize cultivation generally contributes to the reduction of the SOM content (Willms, 2013). Appropriate management, including diverse crop rotations, the planting of catch crops and the recirculation of crop residues and digestate from anaerobic digestion, is necessary to avoid SOM losses (Willms, 2013). As compared to annual crops, perennial energy crops, such as SRC or miscanthus, have the potential to sequester additional carbon in the soil biomass (Don et al., 2012). A recent review (Don et al., 2012) revealed, however, no positive effect on the C-balance if perennial energy crops were established on former grassland.

There is a large body of literature dealing with the impacts of energy cropping on soil nitrogen cycles and N-leaching. Annual energy crops generally need higher and more regular fertiliser inputs than for 
instance SRC or other perennial energy crops. In comparison with annual cropping systems, second generation energy crops are therefore expected to reduce $\mathrm{N}$-surpluses and leaching to the groundwater (Aronsson et al., 2000; Pugesgaard et al., 2014). Impacts of annual energy crops on N-leaching are, however, expected to differ widely depending on the actual field management practices and the local site conditions (Gebel et al., 2013). An assessment of different annual energy crops from Saxony nevertheless shows potential reductions in N-leaching to the groundwater with increased cultivation of maize and oilseed rape and reductions in winter cereal cultivation if the conversion of grassland to arable land is avoided (Gebel et al., 2013).

Energy crops also differ in their water-use efficiency and exhibit widely differing rates of evapotranspiration. Concerns have been raised that the cultivation of water-demanding energy crops, such as SRC, can reduce groundwater recharge and affect the hydrology of local catchments if grown in large quantities (Dimitriou et al., 2009). Scientific results indicate that the effects of energy crops on local water cycles are highly site-specific and differ according to the crop and the variety, the local precipitation and soil conditions (Dimitriou et al., 2009). Proposals have been made to label energy crop reproductive material according to its water use strategy in order to enable farmers to choose locally appropriate varieties (Schmidt-Walter et al., 2014).

With the exception of water consumption, second generation, perennial energy crops are expected to improve the environmental performance of energy cropping as compared to annual energy crops. Positive effects are, however, much less likely, if the establishment of energy crops directly or indirectly involves the conversion of permanent grasslands or other natural or semi-natural habitats.

\section{Indirect impacts}

Indirect land use change (ILUC) occurs when land with a high carbon storage capacity (generally implying land with biodiversity-rich natural or semi-natural land cover) is converted to farmland to meet the demand for commodities displaced by the production of biofuel feedstocks (Plevin et al., 2010). Examples include the encroachment of pastures into the Amazonian forest caused by the replacement of livestock farming by soy and biofuel production at its original site (Arima et al., 2011), and the conversion of Indonesian lowland tropical rainforest and the ploughing up of grasslands in the US to substitute farmland for food/fodder production lost to oil palm or corn cultivation for biofuel production at other locations (Fargione et al., 2008; Searchinger et al., 2008). Indirect land use change not only affects the sustainability of energy cropping in the tropics and the prairies of North America, but can also be observed in the cultural landscapes of Europe. In Germany, grassland which is converted to cropland is in most cases not directly used for energy cropping, but may be used to produce other crops which are competing with the energy crops for land (Laggner et al., 2014). The 
effects of ILUC on GHG emissions and biodiversity are hard to quantify scientifically, but have been shown to potentially exceed the direct effects of energy cropping (Lapola et al., 2010; Plevin et al., 2010; Dumortier et al., 2011; Immerzeel et al., 2014).

\subsection{The study areas}

\subsubsection{Location, geology and climate}

The data collection for this work was carried out in two study regions in Central Germany (Fig. $1.7 \& 1.8$ ). For the purpose of the following chapters they will be referred to as the 'Lower Saxon hills' (LS, 1,118 km²) and the 'Thuringian Basin' (TB, $1058 \mathrm{~km}^{2}$ ). As this work was part of the larger research framework 'BEST - Bioenergie Regionen Stärken' ('Making bioenergy regions stronger') research from a wide variety of scientific disciplines took place in these regions in 2011 and 2012. The first study region, the Lower Saxon hills, is defined by the administrative borders of the county of Göttingen in southern Lower Saxony. The second study region, the Thuringian Basin, extends from the city of Mühlhausen in the west to Kölleda in the east and from Erfurt in the south to Hornsömmern in the north. It ranges across parts of four Thuringian counties, i.e. the county of Unstrut-Hainich, the county of Gotha, the county of Sömmerda and the city of Erfurt.

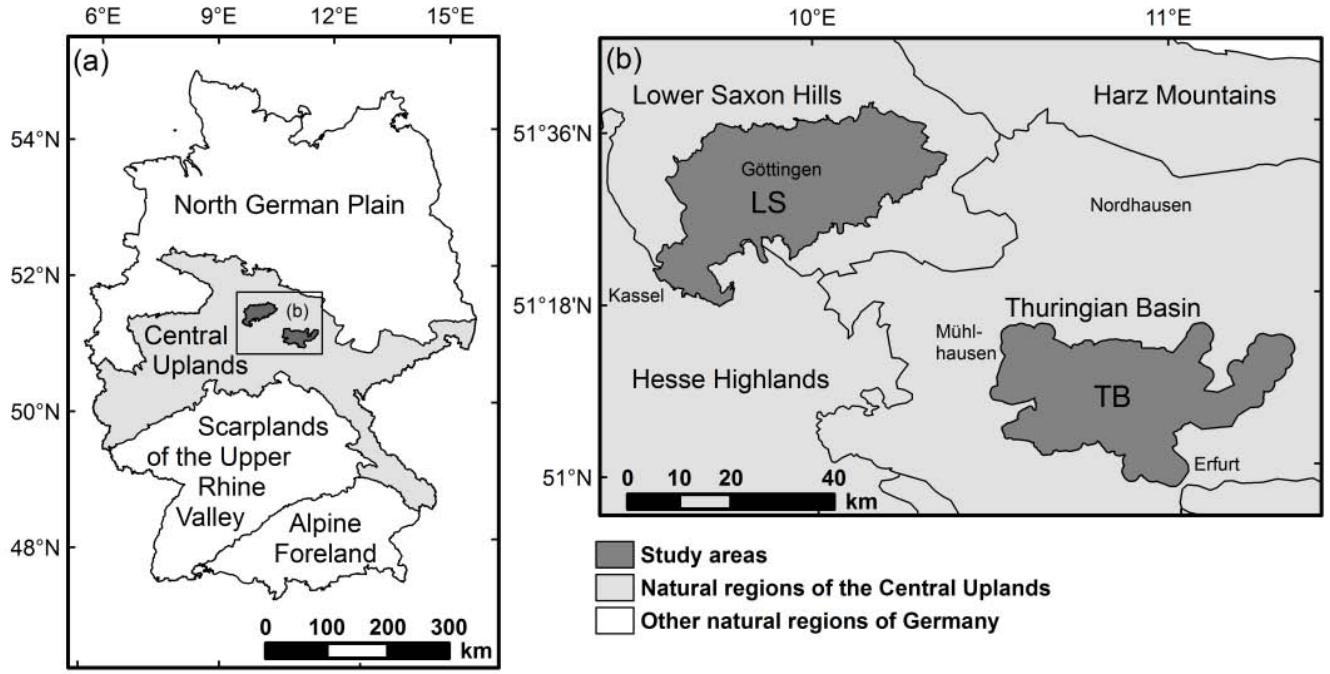

Fig. 1.7 Location of the two study regions (a) in Germany and (b) within the German Central Uplands (LS - Lower Saxon hills, TB - Thuringian Basin). Borders of LS are congruent with the county of Göttingen in Lower Saxony. TB represents the parts of the Thuringian Basin which were part of the larger research framework BEST in which this work was conducted. The map is based on Universal Transverse Mercator (UTM) projection; zone $32 \mathrm{~N}$ (WGS 1984). Biogeographical boundaries were adopted from Meynen \& Schmithüsen (1953-1962). 

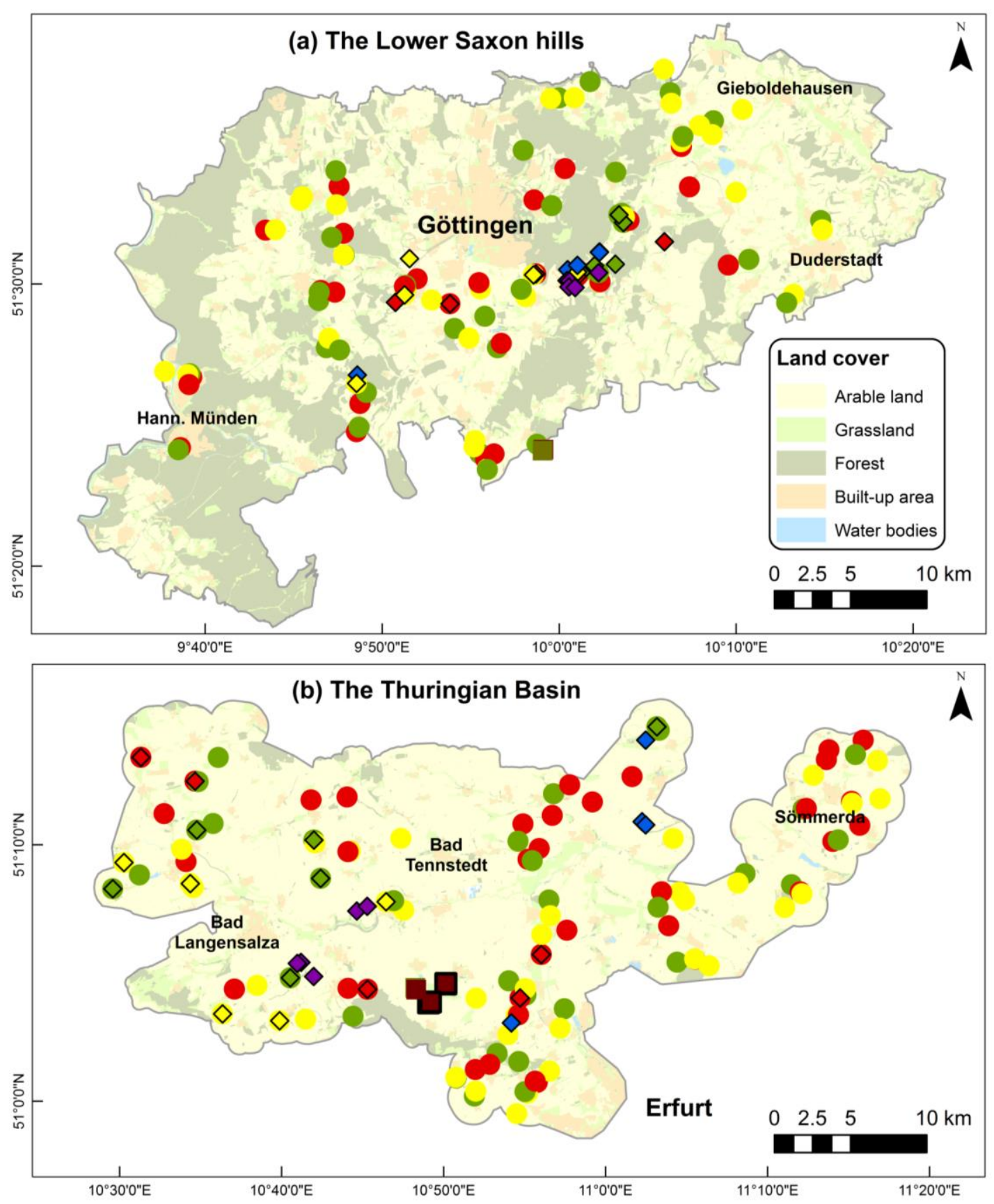

\section{Sampling sites}

\section{Chpt. 2 - Field management Chpt. 3 - Light regime}

Maize (summer-sown)

Wheat (winter-sown)

Barley (winter-sown)
$\diamond$ Maize (summer-sown)
$\diamond$ Wheat (winter-sown)
$\checkmark$ Barley (winter-sown)
$\diamond$ Oilseed rape (winter-sown)
$\diamond$ AES (winter-sown wheat)

\section{Chpt. 4 - Short rotation coppices}

Willow SRC (established 2011)

- Poplar SRC (establ. 2011)

$\square$ Willow SRC (establ. 2005-2008)

$\square$ Poplar SRC (establ. 2005-2008)

Fig. 1.8 Location of the sampling sites within the two study regions (a) the Lower Saxon hills and (b) the Thuringian Basin. The maps are based on Universal Transverse Mercator (UTM) projection; zone 32 N (WGS 1984). 
Both study regions are characterised by a hilly countryside with plains highly suitable for agricultural production due to glacial loess deposits. The Lower Saxon hills are dominated by a mosaic of geological sediments from the Germanic Trias, including Buntsandstein, Muschelkalk and to a lesser extent also Keuper (Fig. 1.9). Loess deposits are mainly found in the Leine valley west of Göttingen and in the central part of the northern Eichsfeld in the east of the county. Contrarily, the Thuringian Basin is characterised by a mosaic of loess and loam deposits in the valleys and Keuper sediments on the ridges and plateaus. The main Muschelkalk belt is the 'Fahner Höhe' ridge at the southern edge of the study region. Buntsandstein sediments are lacking in the Thuringian Basin.

The altitudinal range of both study areas is similar (Lower Saxon hills 104-579 m a.s.l.; Thuringian Basin 134-413 m a.s.1.), but the climatic conditions differ considerably. Due to the east-west gradient of continentality in Central Europe, the climate in the Thuringian Basin is drier (mean annual precipitation 500-550 $\mathrm{mm}$ ) and slightly warmer (mean annual temperature $9.2^{\circ} \mathrm{C}$ ) than in the Lower Saxon hills (650 mm and $8.7^{\circ} \mathrm{C}$ respectively; DWD, 2013).

\subsubsection{Land use history}

Archaeological records confirm the presence of human settlements and agricultural practices as early as 7000 years before present in the two study regions (Beier \& Einicke, 1994; Jantz, 2008).

The Neolithic people already cultivated emmer and einkorn wheat (Triticum dicoccon and $T$. monococcum respectively), pea (Pisum sativum), lentil (Lens culinaris) and less commonly opium poppy (Papaver somniferum) and barley (Hordeum vulgare) (Behre, 2008).

These crops were cultivated on cleared forests plots. When the soil was depleted, the cultivation shifted to another site and the field was left fallow to regenerate for several years and/or used for grazing purposes (Willerding, 1986). This kind of management, also called 'Feldgraswirtschaft' (i.e. the mixture of cropland and grassland periods), was practiced widely until the medieval ages throughout Central Europe (Pott, 1992). It led to the development of weed assemblages which rather resembled today's grassland plant communities due to the high prevalence of perennial species (Pott, 1992; Hofmeister \& Garve, 2006). Typical cropland species such as Bromus secalinus, Lapsana communis or Fallopia convolvulus have nevertheless been detected regularly in Neolithic fossil records (Hilbig et al., 2013). Lists of arable plant species found in Neolithic fossil records from Central Europe have been published by Willerding (1986) and Jacomet et al. (1991).

An important change in field management occurred during the early to high medieval when the more efficient three-field rotation system ('Dreifelderwirtschaft') replaced the 'Feldgraswirtschaft' in 

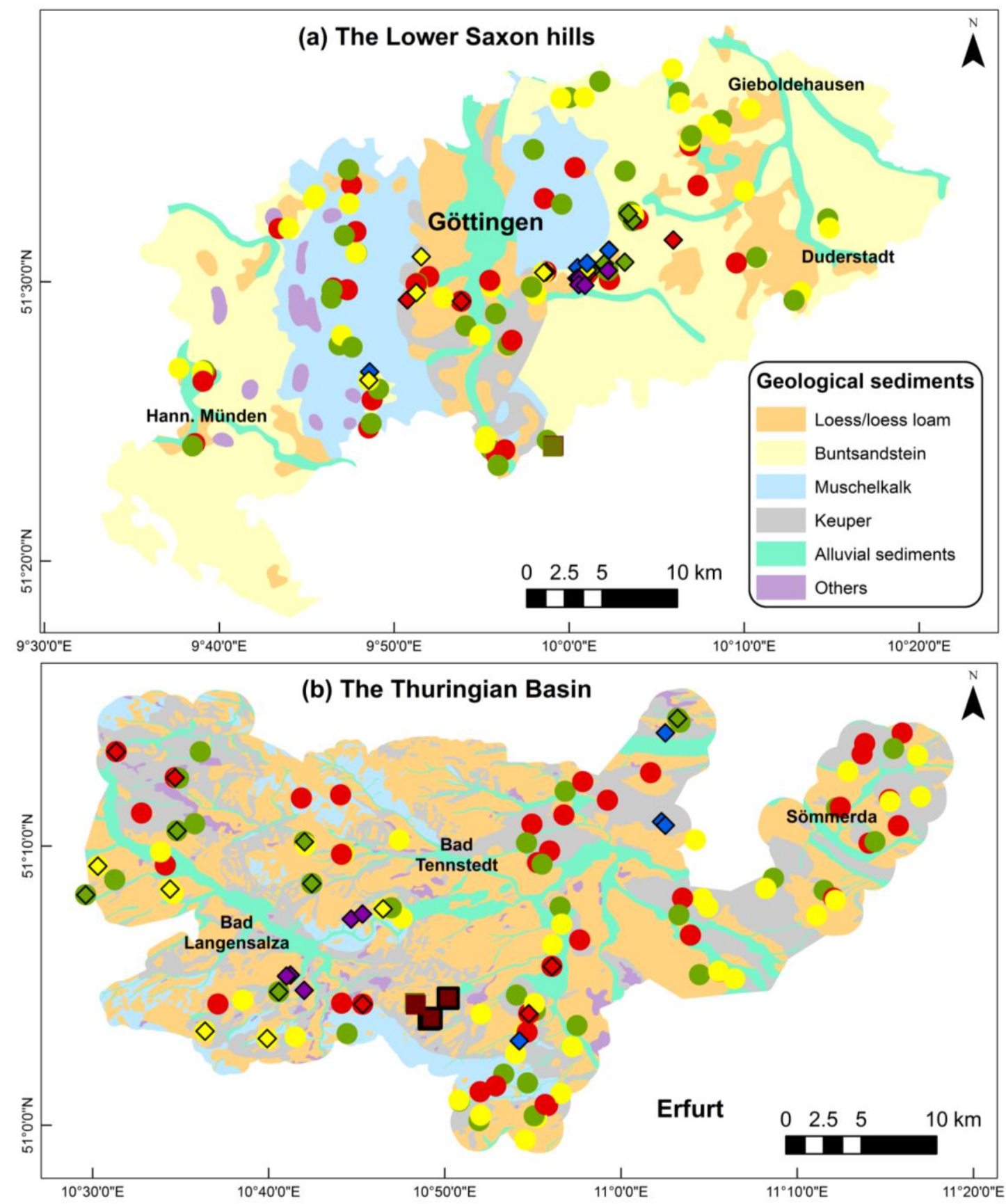

\section{Sampling sites}

Chpt. 2 - Field management Chpt. 3 - Light regime

Maize (summer-sown)
Wheat (winter-sown)
Barley (winter-sown)
$\diamond$ Maize (summer-sown)
$\diamond$ Wheat (winter-sown)
$\diamond$ Barley (winter-sown)
$\checkmark$ Oilseed rape (winter-sown)
$\diamond$ AES (winter-sown wheat)

Chpt. 4 - Short rotation coppices

- Willow SRC (established 2011)

- Poplar SRC (establ. 2011)

$\square$ Willow SRC (establ. 2005-2008)

$\square$ Poplar SRC (establ. 2005-2008)

Fig. 1.9 Geology of the study regions (a) the Lower Saxon hills and (b) the Thuringian Basin. Map (a) is based on the geological map for Lower Saxony (GÜK500, 1:500,000; LBEG, 2014) and (b) is based on the soil geological map of Thuringia (1:100,000; Rau et al., 2000). Both maps are presented in Universal Transverse Mercator (UTM) projection; zone $32 \mathrm{~N}$ (WGS 1984). 
Central Europe (Pott, 1992; Karg, 1995). The crop rotation in the three-field system consisted of winter sown cereals, summer-sown crops (mostly cereals or legumes) and a fallow year during which fields were used as pastures (Pott, 1992). These three types of land use rotated across the holding. Due to the shortening of the fallow period, perennial species became less important in the arable plant assemblages and the proportion of annual species increased (Willerding, 1986; Pott, 1992; Karg, 1995). Historical sources confirm that the three-field system was the prevalent form of field management in the Thuringian Basin and in the Lower Saxon hills since medieval times and was practiced until the middle of the $19^{\text {th }}$ century in many parts of the study areas (Scheidemann, 1959; Rockstuhl, 2012; VG Schlotheim, n.d.). With the course of time, improvements of the three-field system such as land ameliorations, the introduction of new crops (i.e. potatoes and other root crops), improved breeds, and the introduction of mineral fertilisers in the $19^{\text {th }}$ century led to changes in habitat conditions for the arable plant assemblages (Hofmeister \& Garve, 2006). As fallow periods became less common and were largely replaced by root crop cultivation annual disturbance was prevalent on many fields. The importance of perennials declined further and species rich plant communities dominated by annual plant species developed (Pott, 1992). These species rich arable plant assemblages were widespread until the middle of the $20^{\text {th }}$ century.

A major transition in agricultural practices in the study areas occurred after the Second World War. With the wider introduction of synthetic herbicides, the increased availability of mineral fertilisers, improvements in seed cleaning techniques and technical advances of the field machinery the diversity of the arable plant assemblages started to impoverish rapidly (Hofmeister \& Garve, 2006). With the new machinery, land amelioration progressed, leading to increased field sizes and the loss of landscape structural elements such as field margins, wetlands, hedges and copses (Pott, 1992).

This process of intensification differed between the study regions, due to differences in agricultural policies on both sides of the inner German border after 1949. As part of the agrarian reform in the German Democratic Republic many land owners in the Thuringian Basin were expropriated. The land was collectivised and farmed by agricultural production cooperatives (in German: Landwirtschaftliche Produktionsgenossenschaft or LPG). Small fields were joined and landscape features such as hedges, copses, rocks and ponds were removed to allow for more efficient agricultural production with larger machinery (Humm, 1999). A highly productive agricultural landscape with very large fields and few structural landscape elements developed. After the German reunification, the state-owned agricultural land was returned into private hands or reallocated to the regional administrative bodies (federal states or municipalities) to whom it formerly belonged (Dells, 2008). Many federal states, municipalities and private land owners subsequently rented their land to large, privately owned, agricultural cooperatives which are today responsible for farming the land. Consequently, the re-privatization of land did not result in overall decreases in field size. The average size of an administrative field unit is today 18.8 ha in the Thuringian Basin and fields of 20-100 ha dominate the landscape. 
In the Lower Saxon hills no such collectivization took place and the average field size is therefore smaller until today (6.6 ha). Only very few fields exceed 20 ha. Landscape features such as hedges and tree lines are nevertheless not very common, particularly in the areas with fertile loess soils. As a large number of family farm businesses were and are still economically directly dependent on the agricultural production in Western Germany, land use intensity is high and fertile land is only rarely spared from production. Due to these developments, many characteristic and formerly common plant species of arable habitats, such as the common corncockle (Agrostemma githago, Fig. 1.2) or the summer pheasant's eye (Adonis aestivalis), suffered strong declines in Central Germany (Meyer et al., 2013) and are nowadays threatened in many regions of Central Europe.

\subsubsection{Energy cropping in the study areas}

With regard to the importance of energy cropping, the two study areas can be regarded as representative of agricultural areas in western and eastern Germany with fertile soils and a prevalence of arable farming (I.M.A, 2005). Livestock farming is also present in both regions, but is of minor importance as compared to other regions of Germany (I.M.A, 2005). The production of silage maize both for fodder and as biogas feedstock is therefore traditionally less important in both study regions than in regions with a focus on livestock farming. In the Lower Saxon hills, approximately $6 \%$ of the arable land was cultivated with silage maize in 2010 (LWK Niedersachsen, 2010). Assuming that 32\% of the silage maize is used for energy production (i.e. the national average) this results in $2 \%$ of the arable land being cultivated with energy maize. The agricultural literature and interviews with the farmers showed that no systematic differences in the management of energy maize fields and fodder maize fields are to be expected. The influence of energy maize production on arable plant diversity is therefore assumed to originate exclusively from the expansion of the area cultivated with maize. The largest biogas plant in the Lower Saxon hills was established in 2011 and produces about 190 TJ of energy (power and heat) annually (Biogas Göttingen, 2013). It mainly uses maize silage as substrate (Biogas Göttingen, 2013). According to the operators, the necessary feedstocks are produced on approximately 600 ha of arable (Biogas Göttingen, 2013). This results in about $4.8 \%$ of the arable land within a circle of approximately $8 \mathrm{~km}$ around the plant being used for energy production (assuming that $50 \%$ of the land within this circle is cropland) (Biogas Göttingen, 2013). This impact on agricultural production is considerable, but the effects are far from producing "maize deserts" or resulting in large-scale maize monocultures in the region. For comparison, winter-sown wheat is produced each year on about $45 \%$ of the arable land in the Lower Saxon hills (Fig. 1.10; LWK Niedersachsen, 2010).

The situation is similar in the Thuringian Basin. In the county of Sömmerda silage maize was grown on $8 \%$ of the arable land in 2010 (LWA Sömmerda, 2011). Approximately 50\% of the silage maize, 
representing 4\% of the arable land, was used for anaerobic digestion (LWA Sömmerda, 2011). Sömmerda is the county with the highest density of plants for anaerobic digestion in the Thuringian Basin (TLL, 2014). In the county of Unstrut-Hainich maize (including silage maize and grain maize) was produced on only 5\% of the arable land in 2010 (LWA Leinefelde-Worbis, 2011). The prevalence of energy maize production is therefore also generally rather low in the second study area.

A different picture is found for oilseed rape which was grown on $19 \%$ of the arable land in the Lower Saxon hills, on $16 \%$ of the arable land in the county of Sömmerda and on $20 \%$ of the arable land in the county of Unstrut-Hainich in 2010 (LWK Niedersachsen, 2010; LWA Leinefelde-Worbis, 2011; LWA Sömmerda, 2011). Assuming a biodiesel end use for $60 \%$ of the production (the national average) $11.4 \%, 9.6 \%$ and $12 \%$ of the arable land was used for biodiesel feedstocks respectively. These values greatly exceed the national average of 7\% (FNR, 2013c; Destatis, 2014). Farmers are often not aware at the beginning of the season whether their rapeseed produce is going to be used for biodiesel production or for other purposes by the purchaser. The management of oilseed rape fields is therefore also not influenced by the end use.

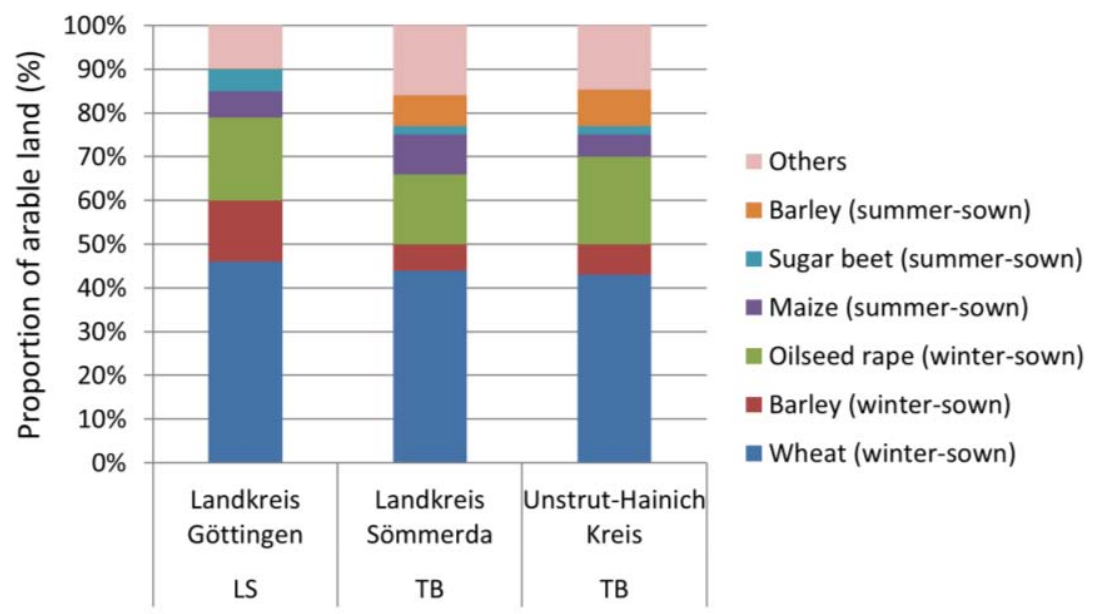

Fig. 1.10 Proportion of arable land used for the production of different crops in the two study regions in 2010. Data from the county of Göttingen (Landkreis Göttingen, LWK Niedersachsen, 2010) represent the situation in the Lower Saxon hills (LS), whereas data from the county of Sömmerda (Landkreis Sömmerda, LWA Sömmerda, 2011) and the county of Unstrut-Hainich (Unstrut-Hainich Kreis, LWA LeinefeldeWorbis, 2011) represent the Thuringian Basin (TB). Maize includes silage maize for fodder and biogas production as well as grain maize. Statistics on the specific share of biogas maize were not consistently available at the county level.

Solid biofuels, such as short rotation coppices, are only produced on few fields in both study regions by farmers who are curious to test new land use options. The current impact on agricultural production at landscape scale is therefore still negligible. 
As shown above, the two study regions are not among the current hotspots of bioenergy production in Germany. They are nevertheless suitable for studying the impacts of biomass production for energy use, as they can beregarded as representative of the wider German agricultural landscape in regions shaped by arable farming, rather than livestock production. The Lower Saxon hills represent the current agricultural situation in the western German regions, whereas the Thuringian Basin is indicative of the situation in the eastern German federal states of Central Germany.

\subsection{General description of the applied methods}

\subsubsection{Vegetation sampling}

The composition of the plant assemblages of energy cropping systems (maize for anaerobic digestion, oilseed rape for biodiesel, short rotation coppices for combustion) and control plots (conventional wheat and barley, fields managed according to agri-environmental schemes) was recorded using standard phytosociological methods (Dierschke, 1994; Wilmanns, 1998). Within a fixed sampling plot the cover ( $\approx$ abundance) of all plant species present was recorded. To allow for comparisons with previous studies we used a standard plot size of $100 \mathrm{~m}^{2}(2 \mathrm{~m} \times 50 \mathrm{~m})$ in arable fields (compare van Elsen, 1994) and a plot size of $25 \mathrm{~m}^{2}(1 \mathrm{~m} \times 25 \mathrm{~m})$ in the short rotation coppices. The Braun-Blanquet cover abundance scale with modifications according to Wilmanns (1998) was applied consistently for all vegetation assessments (Table 1.1). It allows characterizing plant assemblages based on the cover and/or abundance of each species present.

Additionally, the total plant cover, the height, cover and development stage of the crop, the mean height and total cover of weeds, the height and cover of the tree/shrub layer, the cover of the moss layer and the total flower cover at the time of the survey were estimated visually. An exemplary data sheet as used for the vegetation survey can be found in appendix 1.A. The abiotic environmental variables recorded for each plot included the geographic coordinates, slope and aspect, elevation a. s. 1 . and the soil texture.

Table 1.1 Braun-Blanquet cover abundance scale according to Wilmanns (1998).

\begin{tabular}{lll}
\hline Symbol & $\begin{array}{l}\text { No. of } \\
\text { individuals }\end{array}$ & Cover \\
\hline $\mathrm{r}$ & 1 & $<5 \%$ \\
+ & $2-5$ & $<5 \%$ \\
1 & $6-100$ & $<5 \%$ \\
$2 \mathrm{~m}$ & $>100$ & $<5 \%$ \\
$2 \mathrm{a}$ & - & $\geq 5 \%$, but $<15 \%$ \\
$2 \mathrm{~b}$ & - & $\geq 15 \%$, but $<25 \%$ \\
3 & - & $\geq 25 \%$, but $<50 \%$ \\
4 & - & $\geq 50 \%$, but $<75 \%$ \\
5 & - & $\geq 75 \%$, but $<100 \%$ \\
\hline
\end{tabular}




\subsubsection{Soil sampling and analyses}

\subsubsection{1 $p H$}

To measure the $\mathrm{pH}$ we used a standard procedure as described in HFA (2005). $10 \mathrm{~g}$ of fresh soil were mixed with $25 \mathrm{~mL}$ of demineralised water. After a minimum of 10-12 hours of immersion, the $\mathrm{pH}$ in $\mathrm{H}_{2} \mathrm{O}$ was measured with a $\mathrm{pH}$-meter. After adding $1.86 \mathrm{~g}$ of $\mathrm{KCl}$ and waiting for its complete dissolution, the $\mathrm{pH}$ was measured again with the same $\mathrm{pH}$ meter to obtain $\mathrm{pH}_{\mathrm{KCl}}$.

\subsubsection{Effective cation-exchange capacity (ECEC) and base saturation}

The effective cation-exchange capacity $\left(\mathrm{ECEC}\right.$, in $\mathrm{mmol}_{\mathrm{c}} \mathrm{kg}^{-1}$ ) is a measure for the sum of the charges of all exchangeable cations of a soil. It describes the amount of cations which are available for plant growth at intermediate time scales. Contrary to the potential cation-exchange capacity (CEC), ECEC is independent of the soil $\mathrm{pH}$ and can therefore be used to compare cation availability across a wide range of different soils. For the purpose of this work ECEC was determined by inductively coupled plasma analysis (ICP) of a $\mathrm{BaCl}_{2}$ soil percolate (HFA, 2005). $2.5 \mathrm{~g}$ of fresh soil were percolated with $100 \mathrm{~mL}$ of $0.1 \mathrm{~mol} \mathrm{~L}^{-1} \mathrm{BaCl}_{2}$-solution during $3 \mathrm{~h}$. To avoid biotic contamination, the percolate was subsequently mixed with $5 \mathrm{~mL}$ of $65 \% \mathrm{HNO}_{3}$ and kept in the freezer. We used ICP analysis to determine the specific contents of the different cations in the soil samples. The ICP analysis works based on atomic emission spectroscopy, i.e. it measures the specific light emissions of ions which, at extremely high temperatures, return from an excited electronic state to the ground electronic state (Boumans, 1987).

Based on the ICP results the base saturation (BS, in \%) was calculated as the sum of the measured amounts of all basic cations divided by the sum of all measured cations (eq. 1.1).

$$
B S=\frac{\left[\mathrm{Ca}^{2+}+\mathrm{Mg}^{2+}+\mathrm{K}^{+}\right]}{\left[\mathrm{Ca}^{2+}+\mathrm{Mg}^{2+}+\mathrm{K}^{+}+\mathrm{Al}^{3+}+\mathrm{Mn}^{2+}+\mathrm{Fe}^{2+}+\mathrm{H}^{+}\right]}
$$

\subsubsection{C/N-ratio and soil organic matter content}

The $\mathrm{C} / \mathrm{N}$-ratio of the soil was determined with a $\mathrm{C} / \mathrm{N}$-elemental analyser (vario EL III, Elementar, Hanau, Germany). The total amount of carbon $\left(\mathrm{C}_{\mathrm{tot}}\right)$ and nitrogen $\left(\mathrm{N}_{\mathrm{tot}}\right)$ were determined from samples of $10 \mathrm{mg}$ of dried soil prepared for ignition in tin capsules. The $\mathrm{C} / \mathrm{N}$-elemental analyser measures $\mathrm{C}$ and $\mathrm{N}$ based on catalytic tube combustion in an oxygenated $\mathrm{CO}_{2}$-atmosphere at high temperatures (Elementar Analysesysteme $\mathrm{GmbH}, 2005$ ). The freed gases are separated from each other and quantified with a thermal conductivity detector. 
The amount of organic carbon $\left(\mathrm{C}_{\mathrm{org}}\right)$ in the soil samples was obtained based on the loss-on-ignition method. Samples were heated to $450{ }^{\circ} \mathrm{C}$ for at least $5 \mathrm{~h}$ to burn all organic carbon. Subsequently, the amount of the remaining inorganic carbon $\left(\mathrm{C}_{\text {inorg }}\right)$ was measured with the $\mathrm{C} / \mathrm{N}$-elemental analyser based on $20 \mathrm{mg}$ of the raw ash. $\mathrm{C}_{\text {inorg }}$ was subtracted from the total carbon $\left(\mathrm{C}_{\text {tot }}\right)$ to obtain $\mathrm{C}_{\text {org. }}$. An estimate of the soil organic matter content (in \%) was obtained by multiplying $\mathrm{C}_{\text {org }}$ with the factor 1.72 (Baize, 1993).

\subsubsection{Plant-available phosphorus}

In the soil, phosphorus (P) is part of a range of organic and inorganic compounds. The vast majority of the $\mathrm{P}$ is not immediately available to be absorbed by plants as it is bound in minerals or is part of the soil organic matter. For ecological studies the plant-available $\mathrm{P}$, i.e. the amount of $\mathrm{P}$ in the soil which can easily be absorbed by plants, is of importance. To measure the amount of plantavailable $\mathrm{P}$, anion-exchange resin bags can be used to simulate the P-exchange at the roots (Sibbesen, 1977). This method captures both the soluble P and non-stable inorganic P-compounds of the soil solution (Sibbesen, 1977). The fraction of non-stable inorganic compounds which is absorbed by the plants depends on the concentration of these compounds in the soil solution. This process can be reproduced with the resin bag method. To enable the $\mathrm{P}$ to bind to the resin, $1 \mathrm{~g}$ of fresh soil and a resin bag were immersed in $30 \mathrm{~mL}$ demineralised water and the mixture was agitated for 16 hours. In a second step, the $\mathrm{P}$ was extracted again from the resin bag by washing the bag twice for $30 \mathrm{~min}$, first with $25 \mathrm{~mL}$ of $10 \% \mathrm{NaCl}$-solution and afterwards with $25 \mathrm{~mL}$ of $2 \% \mathrm{NaOH}$-solution. Both solutions with their respective P-fractions were joined. The P-content of the complete solution was measured colourimetrically with the molybdate/ascorbic acid method as modified by Murphy \& Riley (1962).

\subsubsection{Measuring PAR transmissivity}

To determine the shading effect of high-yielding energy crops, the proportion of photosynthetically active radiation reaching the ground in energy crop stands and control crops (PAR transmissivity, in \%) was determined. Quantum sensors (LI-190 Quantum Sensor, LI-COR, Lincoln, Nebraska, USA; Biggs et al., 1971) were used to measure the PAR flux density (in $\mu$ mol photons $\mathrm{m}^{-2} \mathrm{~s}^{-}$ ${ }^{1}$ ) above and below the crop canopy. To measure how much PAR was available for weed growth below the crop canopy, one PAR sensor was positioned at ground level $\sim 15 \mathrm{~cm}$ above the soil surface in order to record the light climate experienced by the weeds (transmitted PAR; PAR $_{\text {trans }}$ ). A second PAR sensor was placed $\sim 50 \mathrm{~cm}$ above the crop canopy for synchronously measuring incident PAR flux density $\left(\mathrm{PAR}_{\text {inc }}\right)$. Incident and transmitted PAR were recorded synchronously with a LI-1400 data logger (LI-COR, Lincoln, Nebraska, USA). PAR transmissivity (TPAR, in \%) was calculated as 


$$
T P A R=\frac{P A R_{\text {trans }}}{P A R_{\text {inc }}} * 100
$$

To avoid biased readings, sensors were placed with great care in the stand in order to avoid damaging the crop canopy. The mobile sensor was mounted at the end of a $1.5 \mathrm{~m}$-long stick which allowed conducting the measurements at a distance from the operator where he influenced radiation flux density only minimally. Both sensors rotated freely so that they were always in horizontal position. In each survey plot, ten measuring points were randomly selected and five consecutive light measurements taken at time steps of $\sim 5 \mathrm{~s}$ at each point. Mean TPAR per plot was obtained by averaging over the five consecutive measurements per point and subsequently calculating the mean across the ten points per plot.

All PAR readings were obtained around noon time (10 a.m. to 3 p.m.) on days with homogeneous sky conditions without rapid fluctuation of incident radiation. Although sky conditions and sun angle necessarily varied between different measurement days, we are confident that our data are not biased by these variations, as Hipps (1983) showed that in late-season crop stands with high leaf area indices, measurements of PAR interception and transmission are not influenced by sun angle and cloud cover.

\subsubsection{Data analysis}

\subsubsection{General comments on the statistical approaches used}

In this section a short general overview of the main statistical approaches applied will be given. More specific descriptions of the data analyses can be found in the 'methods' sections of the respective chapters. The main analyses of this thesis applied a correlative approach, i.e. it was determined how well variations in arable plant diversity could be represented by (multiple) linear regression models with a set of predictors. For multivariate response variables we applied redundancy analyses (RDA) or canonical correspondence analyses (CCA). Both techniques are also correlative approaches. In CCA, the components of the response matrix $A$ (species matrix) and the predictor matrix $B$ (i.e. management, environmental and spatial factors) are extracted in a way which maximises their correlation in a single step (van den Wollenberg, A. L., 1977). In RDA two steps are executed. First, the components of the response matrix $A$ are extracted maximising their correlation with the predictor matrix $B$. The components of the resulting new matrix $C$ are then extracted by maximising their correlation with the response matrix $A$ (van den Wollenberg, A. L., 1977). The redundancy statistic $R^{2}$ (more precisely termed 'regression coefficient of determination' for univariate regression analyses) gives the percentage of the variation of the response matrix $A$ explained by the predictor matrix $B$ (Peres-Neto et al., 2006). For RDA the redundancy statistic can be directly determined (van den Wollenberg, A. L., 1977). For CCA the proportion of the total inertia attributable to the predictor 
matrix is commonly used in ecological research as redundancy statistic (Peres-Neto et al., 2006; Legendre, 2008). $R^{2}$ varies with the degrees of freedom of the respective model and with the sample size (Peres-Neto et al., 2006). If several models with different numbers of predictors and/or differing in sample size are to be compared $R^{2}$ needs to be adjusted to account for these variations. $R^{2}$ adjusted, defined as

$$
R_{\text {adjusted }}^{2}=\frac{n-1}{n-p-1}\left(1-R^{2}\right)
$$

where $n$ is the sample size and $p$ is the number of predictors, is commonly applied for this purpose in ecological assessments (Peres-Neto et al., 2006; Legendre, 2008).

Univariate and multivariate correlative statistics are useful tools which can be used to explore and also to refute hypotheses. Correlative statistics can also support hypotheses, but they can never be interpreted as prove of a causal relationship between the predictor and its response variable. The results presented in the following chapters should be interpreted with this limitation in mind.

\subsubsection{Variation partitioning}

In ecological systems it is common to be confronted with a wide range of predictor variables which are interrelated with each other. These predictor variables can often be clustered and organised in subject-specific groups or 'sets of predictors'. To rank the different sets of variables according to their importance and to explore the relationships between different sets, 'variation partitioning' is commonly applied in community ecology (Legendre, 2008). Variation partitioning can be used to discern the part of the variation which is exclusively attributable to a certain set of predictors ([a], [b] or [c] in Fig. 1.11), while controlling for the effects of other sets and to quantify the variation which cannot be attributed to a single set of predictors.

The different steps of the variation partitioning according to Legendre (2008) will be illustrated here by using an example set of predictors represented by the red circle in Fig. 1.11. Firstly, the 'gross effect' $([\mathrm{A}]=[\mathrm{a}]+[\mathrm{ab}]+[\mathrm{ac}]+[\mathrm{abc}])$ of each set of predictors is determined by regressing it against the response matrix without incorporating any conditional factors. The fractions $[\mathrm{a}],[\mathrm{b}]$ and $[\mathrm{c}]$ can be obtained directly from partial regression, RDA or CCA by partialling out the effects of all other predictors in the model. The significance of these so called 'net effects' can therefore also be determined directly. To obtain $[\mathrm{ab}],[\mathrm{ac}],[\mathrm{bc}]$ and $[\mathrm{abc}]$ further intermediate steps are necessary. The fraction $[a b]$ can be determined by subtracting $[a]$ and $[b]$ from the variation explained by $[A B]$ after partialling out $[\mathrm{C}]$. Likewise, [ac] can be determined by subtracting [a] and [c] from the variation explained by $[A C]$ after partialling out $[B]$. $[a b c]$ is then determined by subtracting $[a],[a b]$ and $[a c]$ from [A]. The significance of the shared fractions can therefore not be determined (Legendre, 2008). 
As some degree of correlation among the predictors is common in ecological research, shared fractions occassionally turn out to be negative (Legendre, 2008).

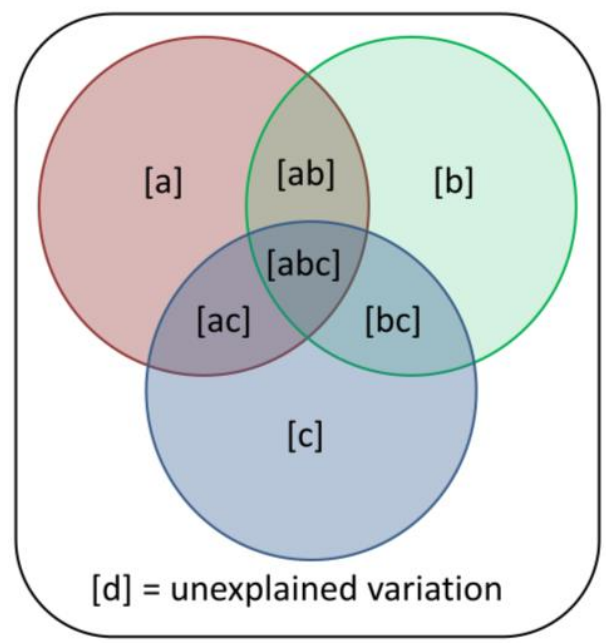

Fig. 1.11 Venn diagram representing the partitioning of variation between three sets of predictors. The rectangle represents $100 \%$ of the variation in the response matrix. The fractions [a], [b] and [c] represent the 'net effect' of the respective set of predictors, whereas the sum of all fractions encompassed by a circle (e.g. [A] $=$ $[a]+[a b]+[a c]+[a b c])$ represents the 'gross effect'. Adapted from Legendre (2008).

\subsection{General objectives and outline of the chapters}

As shown above, important changes in agricultural production patterns are currently taking place in Germany and at the European scale in order to meet the growing demand for bioenergy. Crop frequencies and crop rotations on arable land are changing rapidly as more and more energy crops, such as maize and oilseed rape, are being cultivated (Steinmann \& Dobers, 2013). Changes in cropping patterns are associated with changes in field management practices concerning the timing, quality and quantity of cultivation, fertilisation and herbicide use. Consequently, they can lead to changes in other abiotic factors associated with the field management (e.g. the light climate in the crop stands). In the context of the strong and ongoing decline of arable plant diversity (Sutcliffe \& Kay, 2000; Fried et al., 2009; Storkey et al., 2012; Meyer et al., 2013), it seems urgently necessary to investigate the impacts of these large scale changes in crop frequencies, field management practices and abiotic conditions on arable plant diversity. As arable plants are at the basis of the farmland food web, impacts can be expected to additionally affect organisms of higher trophic levels which depend on arable plants for food, reproduction and shelter. Only a sound understanding of the key factors affecting arable plant diversity will make it possible to develop effective strategies and tools to reconcile agricultural production and biodiversity conservation. This work aims to contribute to fill this research gap. 
In chapter 2, an analysis of the effects of changes in field management practices on arable plant diversity is presented. Records of the arable flora in conventionally managed fields of (energy) maize, winter-sown wheat and winter-sown barley were related to a comprehensive set of field management factors (including fertilisation, herbicide use, conversion tillage, crop rotation and land use history). The relative importance of management vs. environmental factors for arable plant diversity was quantified, and the management factors with the greatest impact were determined. To address the hypothesis that the expansion of maize production negatively affects arable plant diversity if it replaces traditional food and fodder crops, we investigated the importance of the choice of crop for weed cover, species richness and community composition on arable land and discerned interactions with differences in field management between crops.

In chapter 3 the effects of changes in crop stand density and light regime in different conventionally managed crop stands (maize, oilseed rape, winter-sown wheat and winter-sown barley) on arable plant diversity were investigated. We tested the hypothesis that less light reaches the ground in tall-growing maize fields than in fields of oilseed rape or cereals leading to less favourable habitat conditions for the arable flora. Additionally, we compared the light regime between conventionally managed fields and fields managed according to an agri-environmental scheme for the protection of arable plant species. More specifically, the following questions were addressed: (1) How does the light regime at ground level vary between cropping systems? (2) Which spatial scale of observation contributes most to the variation in light conditions? (3) How much of the variation in PAR transmissivity between arable fields can be explained by crop performance, field management and/or regional effects?

Whereas chapters 2 and 3 are dealing with the impacts of annual, widely cultivated energy crops on arable plant diversity, chapter $\mathbf{4}$ focusses on an alternative, 'second-generation' bioenergy feedstock, which is still in the 'investigation phase'. Due to potentially high yields and low requirements of fertilisation and herbicide use, short rotation coppices (SRCs) are widely discussed in the scientific community as a promising feedstock to reduce the negative ecological effects of energy cropping. Chapter 4 investigates the impacts of SRC (willow and poplar) on the plant diversity of agricultural landscapes and discusses ways to increase the value of SRC as habitat for vascular plants. The following research questions were addressed: (1) How do habitat conditions and the associated plant communities in SRCs change with the time since planting? (2) How do habitat conditions in SRCs during the different growth stages compare to habitat conditions in other types of land use? Based on these findings the implications for plant species conservation were discussed and management recommendations to maximise positive effects of SRCs on plant diversity were derived.

In chapter 5, the main findings of the previous chapters are summarised and discussed in the wider ecological and political context. 


\subsection{References}

Altieri, M. A. (1999) The ecological role of biodiversity in agroecosystems. Agriculture, Ecosystems and Environment, 74, 19-31.

Amon, T., Amon, B., Kryvoruchko, V., Machmüller, A., Hopfner-Sixt, K., Bodiroza, V. et al. (2007a) Methane production through anaerobic digestion of various energy crops grown in sustainable crop rotations. Bioresource Technology, 98, 3204-3212.

Amon, T., Amon, B., Kryvoruchko, V., Zollitsch, W., Mayer, K., Gruber, L. (2007b) Biogas production from maize and dairy cattle manure - Influence of biomass composition on the methane yield. Agriculture, Ecosystems and Environment, 118, 173-182.

Arima, E. Y., Richards, P., Walker, R., Caldas, M. M. (2011) Statistical confirmation of indirect land use change in the Brazilian Amazon. Environmental Research Letters, 6, 024010 (7pp).

Aronsson, P. G., Bergström, L. F., Elowson, S. N. E. (2000) Long-term influence of intensively cultured short-rotation willow coppice on nitrogen concentrations in groundwater. Journal of Environmental Management, 58, 135-145.

Aust, C. (2012) Abschätzung der nationalen und regionalen Biomassepotentiale von Kurzumtriebsplantagen auf landwirtschaftlichen Flächen in Deutschland. PhD thesis, AlbertLudwigs-Universität, Freiburg im Breisgau.

Baize, D. (1993) Soil science analyses - A guide to current use, John Wiley, Chichester, New York.

Behre, K.-E. (2008) Landschaftsgeschichte Norddeutschlands - Umwelt und Siedlung von der Steinzeit bis zur Gegenwart, Wachholtz, Neumünster.

Beier, H.-J., Einicke, R. (1994) Das Neolithikum im Mittelelbe-Saale-Gebiet und in der Altmark Eine Übersicht und ein Abriss zum Stand der Forschung, Beier \& Beran, Wilkau-Hasslau Beiträge zur Ur- und Frühgeschichte Mitteleuropas, 4.

Benton, T. G., Vickery, J. A., Wilson, J. D. (2003) Farmland biodiversity: is habitat heterogeneity the key? Trends in Ecology and Evolution, 18, 182-188.

Bentsen, N. S., Felby, C. (2012) Biomass for energy in the European Union - a review of bioenergy resource assessments. Biotechnology for Biofuels, 5:25.

BfN (2014) Grünland-Report - Alles im Grünen Bereich? (ed Federal Agency for Nature Conservation, Germany). http://www.bfn.de/fileadmin/MDB/documents/presse/2014/PK _Gruenlandpapier_30.06.2014_final_layout_barrierefrei.pdf, last accessed 25/07/2014.

Biggs, W. W., Edison, A. R., Eastin, J. D., Brown, K. W., Maranville, J. W., Clegg, M. D. (1971) Photosynthesis light sensor and meter. Ecology, 52, 125-131.

Biogas Göttingen (2013) Biogas Göttingen - regenerative Energie für die Region. http://www.biogasgoettingen.de/index.html, last accessed 13/07/2014.

BLE (2013) Entwicklung der Anbaufläche von Winterraps in Deutschland seit 2000. Bundesanstalt für Landwirtschaft und Ernährung. http://berichte.bmelv-statistik.de/EQG-0510030-0000.pdf, last accessed 29/06/2014.

BMU, BMELV (2010) Nationaler Biomasseaktionsplan für Deutschland, Berlin.

Boehmel, C., Lewandowski, I., Claupein, W. (2008) Comparing annual and perennial energy cropping systems with different management intensities. Agricultural Systems, 96, 224-236.

Bohn, U., Neuhäusl, R., Gollub, G., Hettwer, C., Neuhäuslová, Z., Schlüter, H., Weber, H. (eds) (2000/2003) Map of the natural vegetation of Europe. Scale 1:2 500 000. Part 1 - Explanatory text, Landwirtschaftsverlag, Münster.

Boumans, P. W. J. M. (1987) Inductively coupled plasma emission spectroscopy - Part 1 Methodology, instrumentation and performance, Wiley, New York.

Cherubini, F., Strømman, A. H. (2011) Life cycle assessment of bioenergy systems: State of the art and future challenges. Bioresource Technology, 102, 437-451.

Dauber, J., Jones, M. B., Stout, J. C. (2010) The impact of biomass crop cultivation on temperate biodiversity. Global Change Biology - Bioenergy, 2, 289-309. 
Dells, K. (2008) Management and privatization of state-owned agricultural land - case studies from Eastern Germany and Ukraine - lessons learned for countries in transition, FIG/FAO/CNG International Seminar on State and Public Sector Land Management, Verona, Italy, 09/09/2008.

Destatis (2007) Land- und Forstwirtschaft, Fischerei - Bodennutzung der Betriebe Agrarstrukturerhebung 2007 (Fachserie 3, Reihe 2.1.2). https://www.destatis.de/DE/ Publikationen/Thematisch/LandForstwirtschaft/Bodennutzung/Bodennutzung2030212079004.pdf? _ blob=publicationFile, last accessed 26/07/2014.

Destatis (2014) Feldfrüchte und Grünland - Ackerland nach Hauptfruchtgruppen und Fruchtarten. https://www.destatis.de/DE/ZahlenFakten/Wirtschaftsbereiche/LandForstwirtschaftFischerei/Feldfr uechteGruenland/Tabellen/AckerlandHauptfruchtgruppenFruchtarten.html, last accessed 26/07/2014.

Dierschke, H. (1994) Pflanzensoziologie - Grundlagen und Methoden, E. Ulmer, Stuttgart.

Dimitriou, I., Busch, G., Jacobs, S., Schmidt-Walter, P., Lamersdorf, N. (2009) A review of the impacts of short rotation coppice cultivation on water issues. Landbauforschung vTI - Agriculture and Forestry Research, 3, 197-206.

Don, A., Osborne, B., Hastings, A., Skiba, U., Carter, M. S., Drewer, J. et al. (2012) Land-use change to bioenergy production in Europe: implications for greenhouse gas balance and soil carbon. Global Change Biology - Bioenergy, 4, 372-391.

Dumortier, J., Hayes, D. J., Carriquiry, M., Dong, F., Du, X., Elobeid, A. et al. (2011) Sensitivity of carbon emission estimates from indirect land-use change. Applied Economic Perspectives and Policy, 33, 428-448.

DWD (2013) Klimadaten - Mittelwerte 30-jähriger Perioden, Deutscher Wetterdienst. http://www.dwd.de/bvbw/appmanager/bvbw/dwdwwwDesktop?_nfpb=true\&_pageLabel=_dwdw ww_klima_umwelt_klimadaten_deutschland\&T82002gsbDocumentPath=Navigation\%2FOeffentli chkeit\%2FKlima_Umwelt\%2FKlimadaten\%2Fkldaten_kostenfrei\%2Fkldat_D_mittelwerte_ node.html\%3F_nnn\%3Dtrue, last accessed 25/06/2013.

EEA (2012) Primary energy consumption by fuel in the EU-27 and in the non-EU-27 EEA countries (ed European Environment Agency). http://www.eea.europa.eu/data-and-maps/figures/primaryenergy-consumption-by-fuel-3, last accessed 13/06/2014.

EEA (2013a) Mix of energy crops, 2006-2008 (left) and EEA scenario for environmentally compatible energy cropping in 2020 (right) (ed European Environment Agency). http://www.eea.europa.eu/ data-and-maps/figures/mix-of-energy-crops-200620132008\#tab-metadata, last accessed $13 / 06 / 2014$.

EEA (2013b) Total primary energy consumption by energy source in 2010 (ed European Environment Agency). http://www.eea.europa.eu/data-and-maps/figures/total-primary-energy-consumption-by3\#tab-european-data, last accessed 13/06/2014.

Elementar Analysesysteme GmbH (2005) Vario EL III CHNOS Elemental Analyzer - Operating instructions, Hanau, Germany.

Ellenberg, H., Leuschner, C. (2010) Vegetation Mitteleuropas mit den Alpen. 6. ed., Eugen Ulmer KG, Stuttgart.

Evans, D. M., Pocock, M. J. O., Brooks, J., Memmott, J. (2011) Seeds in farmland food-webs: Resource importance, distribution and the impacts of farm management. Biological Conservation, 144, 2941-2950.

Everaars, J., Frank, K., Huth, A. (2014) Species ecology and the impacts of bioenergy crops: an assessment approach with four example farmland bird species. Global Change Biology Bioenergy, 6, 252-264.

Fargione, J., Hill, J., Tilman, D., Polasky, S., Hawthorne, P. (2008) Land clearing and the biofuel carbon debt. Science, 319, 1235-1238.

FNR (2012) Biokraftstoffe (ed Fachagentur Nachwachsende Rohstoffe e. V.). http://biokraftstoffe.fnr.de/kraftstoffe/, last accessed 29/06/2014.

FNR (2013a) Anteil erneuerbarer Energien am Endenergieverbrauch 2012 (ed Fachagentur Nachwachsende Rohstoffe $\quad$ e. $\quad$ V.). http://mediathek.fnr.de/grafiken/daten-und- 
fakten/bioenergie/anteil-erneuerbarer-energien-am-endenergieverbrauch.html, last accessed $14 / 06 / 2104$.

FNR (2013b) Biogas: an introduction, (ed Fachagentur Nachwachsende Rohstoffe e. V.) http://mediathek.fnr.de/media/downloadable/files/samples/b/r/brosch.biogas-2013-en-web-pdf.pdf, last accessed 28/06/2014.

FNR (2013c) Cultivation of renewable resources in Germany, (ed Fachagentur Nachwachsende Rohstoffe e. V.) http://mediathek.fnr.de/media/downloadable/files/samples/r/l/rl_fnr4_0184 _grafik_nawaro_.jpg, last accessed 07/01/2013.

FNR (2013d) Entwicklung der Maisanbaufläche in Deutschland (ed Fachagentur Nachwachsende Rohstoffe e. V.). http://mediathek.fnr.de/grafiken/daten-und-fakten/bioenergie/biogas/entwicklungder-maisanbauflache-in-deutschland.html, last accessed 14/06/2014.

FNR (2013e) Kraftstoffverbrauch Deutschland 2012 (ed Fachagentur Nachwachsende Rohstoffe e. V.). http://mediathek.fnr.de/grafiken/daten-und-fakten/bioenergie/biokraftstoffe/biokraftstoffe-indeutschland.html, last accessed 14.06.2014.

FNR (2013f) Maisanbau in Deutschland, (ed Fachagentur Nachwachsende Rohstoffe e. V.) http://mediathek.fnr.de/grafiken/pressegrafiken/maisanbau-in-deutschland.html, last accessed $18 / 05 / 2014$.

FNR (2013g) Massebezogener Substrateinsatz in Biogasanlagen 2012 (ed Fachagentur Nachwachsende Rohstoffe e. V.). http://mediathek.fnr.de/grafiken/daten-und-fakten/bioenergie/ biogas/massebezogener-substrateinsatz-in-biogasanlagen.html, last accessed 14/06/2014.

FNR (2013h) Massebezogener Substrateinsatz nachwachsender Rohstoffe in Biogasanlagen 2012 (ed Fachagentur Nachwachsende Rohstoffe e. V.). http://mediathek.fnr.de/grafiken/daten-undfakten/bioenergie/biogas/massebezogener-substrateinsatz-nachwachsender-rohstoffe-inbiogasanlagen.html, last accessed 14/06/2014.

FNR (2013i) Reduktion von Treibhausgas-Emissionen durch erneuerbare Energien 2012 (ed Fachagentur Nachwachsende Rohstoffe e. V.). http://mediathek.fnr.de/grafiken/daten-undfakten/bioenergie/thg-vermeidung-durch-die-nutzung-erneuerbarer-energien-in-2012.html, last accessed 25/07/2014.

FNR (2013j) Rohstoffe für die Biodieselproduktion in Deutschland 2012 (ed Fachagentur Nachwachsende Rohstoffe e. V.). http://mediathek.fnr.de/grafiken/daten-und-fakten/ bioenergie/biokraftstoffe/rohstoffe-fur-die-biodieselproduktion-in-deutschland-2012.html, last accessed 14/06/2014.

FNR (2013k) Stromerzeugung aus Biomasse 2012 (ed Fachagentur Nachwachsende Rohstoffe e. V.). http://mediathek.fnr.de/grafiken/daten-und-fakten/bioenergie/biokraftstoffe/stromerzeugung-ausbiomasse.html, last accessed 14/06/2014.

FNR (20131) Wärmenutzung aus Biogasanlagen 2012 (ed Fachagentur Nachwachsende Rohstoffe e. V.). $\quad$ http://mediathek.fnr.de/grafiken/daten-und-fakten/bioenergie/biogas/warmenutzung-ausbiogasanlagen.html, last accessed 14/06/2014.

FNR (2014a) Brutto - Stromerzeugung in Deutschland 2013 (ed Fachagentur Nachwachsende Rohstoffe e. V.). http://mediathek.fnr.de/grafiken/daten-und-fakten/bioenergie/bruttostromerzeugung.html, last accessed 14/06/2014.

FNR (2014b) Energiebereitstellung aus erneuerbaren Energien 2013 (ed Fachagentur Nachwachsende Rohstoffe e. V.). http://mediathek.fnr.de/grafiken/daten-und-fakten/bioenergie/diebedeutung-der-bioenergie-unter-den-erneuerbaren-energien-endenergie.html, , last accessed $14 / 06 / 2014$.

FNR (2014c) Leitfaden - Feste Brennstoffe (ed Fachagentur Nachwachsende Rohstoffe e. V.). http://mediathek.fnr.de/media/downloadable/files/samples/l/e/leitfadenfestebiobrennstoffe2014web.pdf, last accessed 07/03/2014.

FNR (2014d) Wärmebereitstellung aus erneuerbaren Energien (ed Fachagentur Nachwachsende Rohstoffe e. V.). http://mediathek.fnr.de/grafiken/daten-und-fakten/bioenergie/fest-biobrennstoffe/ warme-aus-biomasse.html, , last accessed 14/06/2014. 
Fried, G., Petit, S., Dessaint, F., Reboud, X. (2009) Arable weed decline in Northern France: Crop edges as refugia for weed conservation? Biological Conservation, 142, 238-243.

Gabriel, D., Tscharntke, T. (2007) Insect pollinated plants benefit from organic farming. Agriculture, Ecosystems and Environment, 118, 43-48.

Gebel, M., Halbfass, S., Bürger, S., Lorz, C. (2013) Long-term simulation of effects of energy crop cultivation on nitrogen leaching and surface water quality in Saxony/Germany. Regional Environmental Change, 13, 249-261.

Gevers, J., Høye, T. T., Topping, C. J., Glemnitz, M., Schröder, B. (2011) Biodiversity and the mitigation of climate change through bioenergy: impacts of increased maize cultivation on farmland wildlife. Global Change Biologiy - Bioenergy, 3, 472-482.

Glemnitz, M., Hufnagel, J., Platen, R. (2008) Einfluss des Biomasseanbaus für Energiebereitstellung auf die Biodiversität, in Landeskultur in Europa - Lernen von den Nachbarn. Heft 5 (ed Deutsche Landeskulturgesellschaft), Müncheberg, pp. 175-192.

Grassini, P., Cassman, K. G. (2012) High-yield maize with large net energy yield and small global warming intensity. PNAS, 109, 1074-1079.

Hagemann, H., Goerke, M., Erlenkötter, M., Schulte, A. (2013) Zertifikat bestätigt nachhaltigen Anbau bei KUP. Holz-Zentralblatt, 50, 1244.

Havlík, P., Schneider, U. A., Schmid, E., Böttcher, H., Fritz, S., Skalský, R. et al. (2011) Global landuse implications of first and second generation biofuel targets. Energy Policy, 39, 5690-5702.

Hermanutz, L. A., Weaver, S. E. (1996) Agroecotypes or phenotypic plasticity? Comparison of agrestal and ruderal populations of the weed Solanum ptycanthum. Oecologia, 105, 271-280.

HFA (2005) Eine Loseblatt-Sammlung der Analysemethoden im Forstbereich (ed Gutachterausschuss Forstliche Analytik), Handbuch Forstliche Analytik - Grundwerk.

Hilbig, W., van Elsen, T., Illig, H., Meyer, S. (2013) Die Herausbildung der Ackerwildkrautflora, ihre jetzige Verarmung und die Bestrebungen zum Schutz der seltenen und gefährdeten Ackerwildkräuter., in Ackerwildkrautschutz - Eine Bibliographie. (ed. Meyer, S., Hilbig, W., Steffen, K., Schuch, S.), BfN-Skripten, 351, 10-52.

Hilton, S., Bennett, A. J., Keane, G., Bending, G. D., Chandler, D., Stobart, R., Mills, P. (2013) Impact of shortened crop rotation of oilseed rape on soil and rhizosphere microbial diversity in relation to yield decline. PLOS ONE, 8, e59859. doi:10.1371/journal.pone.0059859.

Hipps, L. E. (1983) Assessing the interception of photosynthetically active radiation in winter wheat. Agricultural Meterology, 28, 253-259.

Hofmeister, H., Garve, E. (2006) Lebensraum Acker. Reprint of the 2nd ed., Verlag Kessel, RemagenOberwinter.

Hötker, H., Leuschner, C. (2014) Naturschutz in der Agrarlandschaft am Scheideweg - Misserfolge, Erfolge, nеие Wege. http://www.michaelottostiftung.de/de/presse/left-area/04/text_files/file/ mos015_Studie_RZ_140618_lowres\%202.pdf, last accessed 07/10/2014.

Humm, A. M. (1999) Auf dem Weg zum sozialistischen Dorf? - Zum Wandel der dörflichen Lebenswelt in der DDR von 1952 bis 1969 mit vergleichenden Aspekten zur Bundesrepublik Deutschland, Vandenhoeck \& Ruprecht, Göttingen Bd. 131.

I.M.A. (2005) Landwirtschaft in Deutschland (ed information.medien.agrar e. V.). http://www.imaagrar.de/fileadmin/redaktion/download/pdf/agraratlas/Agraratlas_Web_neu.pdf , last accessed 13/07/2014.

Imam, A. G., Allard, R. W. (1965) Population studies in predominantly self-pollinated species. VI. Genetic variability between and within natural populations of wild oats from differing habitats in California. Genetics, 51, 49-62.

Immerzeel, D. J., Verweij, P. A., van der Hilst, F., Faaij, A. P. C. (2014) Biodiversity impacts of bioenergy crop production: a state-of-the-art review. Global Change Biology - Bioenergy, 6, 183209.

Jacomet, S., Brombacher, C., Dick, M. (1991) Palaeoethnobotanical work on Swiss neolithic and bronze age lake dewllings over th past ten years, in New light on early farming - Recent 
developments in palaeoethnobotany (ed J. M. Renfrew), Edinburgh University Press, Edinburgh, pp. 257-274.

Jantz, N. (2008) Vorrats- oder Abfallgrube? - Archäobotanische Untersuchungen an Archiven aus der Linienbandkeramischen Siedlung Grone-A7 bei Göttingen. B. Sc. thesis, Georg-August-University Göttingen.

Jordan, N., Vatovec, C. (2004) Agroecological benefits from weeds, in Weed biology and management (ed Inderjit), Kluwer Academic Publishers, Dordrecht, The Netherlands, pp. 137-158.

Kappas, M. (2013) Estimation of global bioenergy potentials and their contribution to the world's future energy demand - a short review, in Sustainable bioenergy production - an integrated approach (eds H. Ruppert, M. Kappas und J. Ibendorf), Springer, Dordrecht, The Netherlands, pp. $75-95$.

Karg, S. (1995) Plant diversity in late medieval cornfields of northern Switzerland. Vegetation History and Archaeobotany, 4, 41-50.

Kohlbrecher, C., Wesche, K., Hilbig, W., Leuschner, C., Meyer, S. (2012) Veränderungen in der Segetalflora am Kyffhäusergebirge in den letzten 50 Jahren (1961-2011). Landschaftspflege und Naturschutz in Thüringen, 49, 1-9.

Laggner, B., Orthen, N., Osterburg, B., Röder, N. (2014) Ist die zunehmende Biogasproduktion die alleinige Ursache für den Grünlandschwund in Deutschland? - eine Analyse von georeferenzierten Daten zur Landnutzung. Raumforschung und Raumordnung, 72, 195-209.

Lang, G., Rybníček, K., Rybníčeková, E. (2003) Late-glacial and Holocene vegetation history of Europe, in Map of the natural vegetation of Europe. Scale 1:2500 000. Part 1 - Explanatory text (eds U. Bohn, R. Neuhäusl, G. Gollub, C. Hettwer, Z. Neuhäuslová, H. Schlüter und H. Weber), Landwirtschaftsverlag, Münster, pp. 87-104.

Lapola, D. M., Schaldach, R., Alcamo, J., Bondeau, A., Koch, J., Koelking, C., Priess, J. A. (2010) Indirect land-use changes can overcome carbon savings from biofuels in Brazil. PNAS, 107, 33883393.

LBEG (2014) Geologische Übersichtskarte von Niedersachsen 1:500 000 (ed Landesamt für Bergbau, Energie und Geologie Niedersachsen).

Legendre, P. (2008) Studying beta diversity: ecological variation partitioning by multiple regression and canonical analysis. Journal of Plant Ecology, 1, 3-8.

Ludwig, G., Schnittler, M. (1996) Rote Liste gefährdeter Pflanzen Deutschlands, Bonn, Bundesamt für Naturschutz Schriftenreihe für Vegetationskunde, 28.

Luque, R., Campelo, J., Clark, J. (eds) (2011) Handbook of biofuels production : process and technologies, Woodhead Publ., Oxford.

LWA Leinefelde-Worbis (2011) Anbaufläche je Kultur 2000-2010, Landwirtschaftsamt LeinefeldeWorbis.

LWA Sömmerda (2011) Landwirtschaftliche Fläche nach Kulturen 2005-2010, Landwirtschaftsamt Sömmerda.

LWK Niedersachsen (2010) Bestellte Fläche je Feldfrucht und Gemeinde im Landkreis Göttingen 2010, Landwirtschaftskammer Niedersachsen.

Marshall, E. J. P., Brown, V. K., Boatman, N. D., Lutman, P. J., Squire, G. R., Ward, L. K. (2003) The role of weeds in supporting biological diversity within crop fields. Weed Research, 43, 77-89.

Marshall, E. J. P., Moonen, A. C. (2002) Field margins in Northern Europe: their functions and interactions with agriculture. Agriculture, Ecosystems and Environment, 89, 5-21.

Meyer, S., Hoeber, S., Leuschner, C. (2014) Auswirkungen des Energiepflanzenbaus auf die Phytodiversität von Ackerflächen: Ergebnisse einer Literaturstudie, Federal Agency for Nature Conservation, BfN-Skripten, 361.

Meyer, S., Wesche, K., Krause, B., Leuschner, C. (2013) Dramatic losses of specialist arable plants in Central Germany since the 1950s/60s - a cross-regional analysis. Diversity and Distributions, 19, $1175-1187$. 
Meynen, E., Schmithüsen, J. (1953-1962) Handbuch der naturräumlichen Gliederung Deutschlands, Selbstverlag der Bundesanstalt für Landeskunde, Remagen, Germany.

Murphy, J., Riley, J. P. (1962) A modified single solution method for the determination of phosphate in natural waters. Analytica Chimica Acta, 27, 31-36.

NABU (2007) Bedeutung der Flächenstilllegung für die biologische Vielfalt - Fakten und Vorschläge zur Schaffung von ökologischen Vorrangflächen im Rahmen der EU-Agrarpolitik. http://www.bfn.de/fileadmin/MDB/documents/themen/landwirtschaft/flaechenstilllegung_kurzfass ung.pdf, last accessed 25/07/2014.

Nagy, S., Nagy, K., Szép, T. (2009) Potential impact of EU accession on common farmland bird populations in Hungary. Acta Ornithologica, 44, 37-44.

Nemestóthy, K. (2012) Die Bedeutung von Holz als erneuerbarer Energieträger. $B F W$ Praxisinformation, 28, 5-8.

Nitsch, H., Osterburg, B., Roggendorf, W., Laggner, B. (2012) Cross compliance and the protection of grassland - Illustrative analyses of land use transitions between permanent grassland and arable land in German regions. Land Use Policy, 29, 440-448.

Ortloff, M. (2012) Nutzung von Grünlandbiomasse zur Bioenergieerzeugung - Chance oder Risiko für die Phytodiversität? B. Sc. thesis, Georg-August-Universität Göttingen.

Panoutsou, C., Elbersen, B., Böttcher, H. (2011) Energy crops in the European context (ed Intelligent Energy Europe - Biomass Futures). http://www.biomassfutures.eu/public_docs/final_ deliverables/WP8/D8.4\%20Energy\%20crops\%20in\%20the\%20European\%20context\%20(contribu tion\%20to\%20FNR\%20workshop).pdf, last accessed 25/07/2014.

Parish, D. M. B., Hawes, C., Hoad, S. P., Iannetta, P. P. M., Squire, G. R. (2009) The contribution of arable weeds to biodiversity, in Weeds: Management, Economic Impacts and Biology (ed R. V. Kingely), Nova Science Publishers, New York, pp. 61-76.

Peres-Neto, P. R., Legendre, P., Dray, S., Borcard, D. (2006) Variation partitioning of species data matrices: estimation and comparison of fractions. Ecology, 87, 2614-2625.

Plevin, R. J., O'Hare, M., Jones, A. D., Torn, M. S., Gibbs, H. K. (2010) Greenhouse gas emissions from biofuels' indirect land use change are uncertain but may be much greater than previously estimated. Environmental Science \& Technology, 44, 8015-8021.

Pott, R. (1992) Entwicklung von Pflanzengesellschaften durch Ackerbau und Grünlandnutzung. Gartenbauwissenschaften, 57, 157-166.

Pude, R. (2012) Geschätzte Miscanthus-Anbaufläche in Deutschland und Europa. http://www.miscanthus.de/FlaechenSchaetzung.pdf, last accessed 07/03/2014.

Pugesgaard, S., Schelde, K., Larsen, S. U., Laerke, P. E., Jørgensen, U. (2014) Comparing annual and perennial crops for bioenergy production - influence on nitrate leaching and energy balance. Global Change Biology - Bioenergy, available online. DOI: 10.1111/gcbb.12215.

Rau, D., Schramm, H., Wunderlich, J. (2000) Die Leitbodenformen Thüringens. 2. ed. (ed Thüringer Landesanstalt für Geologie), Weimar, Germany, Geowissenschaftliche Mitteilungen von Thüringen, supplement 3.

Rockstuhl, H. (2012) Die Unstrut - Geschichte, Landschaft und Leben am Fluss von der Quelle bis zur Mündung - Vom Eichsfeld, durch das Thüringer Becken, über die Thüringer Pforte bis zur Saale, Rockstuhl, Bad Langensalza.

Rowe, R. L., Street, N. R., Taylor, G. (2009) Identifying potential environmental impacts of largescale deployment of dedicated bioenergy crops in the UK. Renewable and Sustainable Energy Reviews, 13, 260-279.

Sauerbrei, R., Ekschmitt, K., Wolters, V., Gottschalk, T. K. (2014) Increased energy maize production reduces farmland bird diversity. Global Change Biology - Bioenergy, 6, 265-274.

Scheidemann, F. (1959) Aus derDorfgeschichte von Ballenhausen und Bodenhausen. http://ballenhausen.de/cms/upload/ballenhausen/geschichte/Chronik_Ballenhausen_v1_0b.pdf, last accessed 07/06/2014. 
Schmidt-Walter, P., Richter, F., Herbst, M., Schuldt, B., Lamersdorf, N. P. (2014) Transpiration on water use strategies of a young and a full-grown short rotation coppice differing in canopy cover and leaf area. Agricultural and Forest Meteorology, 195/196, 165-178.

Schmitz, N., Henke, J., Klepper, G. (2009) Biokraftstoffe - Eine vergleichende Analyse (ed Fachagentur Nachwachsende Rohstoffe e. V.). http://www.fnr-server.de/ftp/pdf/literatur/pdf_236biokraftstoffvergleich_2009.pdf, last accessed 29/06/2014.

Schneider, C., Sukopp, U., Sukopp, H. (1994) Biologisch-ökologische Grundlagen des Schutzes gefährdeter Segetalpflanzen. Schriftenreihe für Vegetationskunde, 26, 1-356.

Searchinger, T., Heimlich, R., Houghton, R. A., Dong, F., Elobeid, A., Fabiosa, J. et al. (2008) Use of U.S. croplands for biofuels increases greenhouse gases through emissions from land-use change. Science, 319, 1238-1240.

Sibbesen, E. (1977) A simple ion-exchange resin procedure for extracting plant-available elements from soil. Plant and Soil, 46, 665-669.

SRU (2007) Klimaschutz durch Biomasse - Sondergutachten (ed Sachverständigenrat für Umweltfragen).

http://www.umweltrat.de/SharedDocs/Downloads/DE/02_Sondergutachten/2007_SG_Biomasse_B uch.pdf;jsessionid=A420C35A6FB0D24EE9CB94D62485DB26.1_cid335?_blob=publicationFile , last accessed 07/03/2014.

St. Clair, S., Hillier, J., Smith, P. (2008) Estimating the pre-harvest greenhouse gas costs of energy crop production. Biomass and Bioenergy, 32, 442-452.

Steinmann, H.-H, Dobers, E. S. (2013) Spatio-temporal analysis of crop rotations and crop sequence patterns in Northern Germany: potential implications on plant health and crop protection. Journal of Plant Diseases and Protection, 120, 85-94.

Storkey, J., Meyer, S., Still, K. S., Leuschner, C. (2012) The impact of agricultural intensification and land-use change on the European arable flora. Proceedings of the Royal Society B: Biological Sciences, 279, 1421-1429.

Sutcliffe, O. L., Kay, Q. O. N. (2000) Changes in the arable flora of central southern England since the 1960s. Biological Conservation, 93, 1-8.

Taylor, R. L., Maxwell, B. D., Boik, R. J. (2006) Indirect effects of herbicides on bird food resources and beneficial arthropods. Agriculture, Ecosystems and Environment, 116, 157-164.

TLL (2014) Landwirtschaftliche Biogasanlagen in Thüringen (ed Thüringer Landesanstalt für Landwirtschaft). http://www.tll.de/ainfo/bga_info/bga_0806.htm, last accessed 13/07/2014.

Tscharntke, T., Batáry, P., Dormann, C. F. (2011) Set-aside management: How do succession, sowing patterns and landscape context affect biodiversity? Agriculture, Ecosystems and Environment, 143, $37-44$.

Tscharntke, T., Klein, A.-M., Kruess, A., Steffan-Dewenter, I., Thies, C. (2005) Landscape perspectives on agricultural intensification and biodiversity - ecosystem service management. Ecology Letters, 8, 857-874.

UBA (2014) Treibhausgas-Emissionen in Deutschland seit 1990 nach Gasen sowie Ziele für 20082012 (Kyoto-Protokoll), 2020 und 2050 (Bundesregierung) (ed Umweltbundesamt). http://www.umweltbundesamt.de/sites/default/files/medien/384/bilder/dateien/2_abb_thgemissionen_2014-03-07_0.pdf, last accessed 25/07/2014.

Vakkilainen, E., Kuparinen, K., Heinimö, J. (2013) Large industrial users of energy biomass, IEA Bioenergy Task 40 Sustainable International Bioenergy Trade. http://www.bioenergytrade.org/ downloads/t40-large-industrial-biomass-users.pdf, last accessed 06/12/2014.

van den Wollenberg, A. L. (1977) Redundancy analysis - an alternative for canonical correlation analysis. Psychometrika, 42, 207-219.

van Elsen, T. (1994) Die Fluktuation von Ackerwildkraut-Gesellschaften und ihre Beeinflussung durch Fruchtfolge und Bodenbearbeitungs-Zeitpunkt, Universität Gesamthochschule Kassel, Kassel, Ökologie und Umweltsicherung, 9/94. 
Verkerk, P. J., Anttila, P., Eggers, J., Lindner, M., Asikainen, A. (2011) The realisable potential supply of woody biomass from forests in the European Union. Forest Ecology and Management, 261, 2007-2015.

VG Schlotheim (n.d.) Gemeindeportrait Obermehler - Geschichte, Verwaltungsgemeinschaft Schlotheim/Thüringen. http://www.vg-schlotheim.de/scripts/angebote/2682/168519?layout=2 \&ortnav=obermehler\&back=\%2Fscripts \%2Fangebote $\% 2 \mathrm{~F} 2682 \% 2 \mathrm{~F} \% 3$ Fortsfilter\%3D33079\%26fr om\%3Dmitglied\%26ortnav\%3Dobermehler, last accessed 07/06/2014.

Waldhardt, R., Otte, A., Simmering, D., Ginzler, O. (2011) Biogas gegen Biodiversität? DLGMitteilungen, 3/2011, 20-23.

Wardle, D. A. (1992) A comparative assessment of factors which influence microbial biomass carbon and nitrogen levels in soil. Biological Reviews, 67, 321-358.

Wardle, D. A. (1995) Impacts of disturbance on detritus food webs in agro-ecosystems of contrasting tillage and weed management practices. Advances in Ecological Research, 26, 105-184.

Wesche, K., Krause, B., Culmsee, H., Leuschner, C. (2012) Fifty years of change in Central European grassland vegetation: Large losses in species richness and animal-pollinated plants. Biological Conservation, 150, 76-85.

Willerding, U. (1986) Zur Geschichte der Unkräuter Mitteleuropas, Wachholtz, Neumünster Göttinger Schriften zur Vor- und Frühgeschichte, 22.

Willms, M. (2013) Humusbilanzen im Energiepflanzenanbau - Gärreste gezielt zurückführen und Fruchtfolgen anpassen. mais, 2/2013 (40. Jg.), 64-68.

Wilmanns, O. (1998) Ökologische Pflanzensoziologie - Eine Einführung in die Vegetation Mitteleuropas. 6. ed., Quelle \& Meyer, Wiesbaden. 


\title{
Chapter 2
}

Seifert, C., Leuschner, C., Culmsee, H. (2015)

\section{Arable plant diversity on conventional cropland - The role of crop species, management and environment}

Agriculture, Ecosystems and Environment 213: 151-163

http://dx.doi.org/10.1016/j.agee.2015.07.017

\begin{abstract}
Arable plant assemblages are affected by a wide range of management and environmental factors. It is yet unclear which factors are the most important predictors of arable plant diversity and composition in contemporary agricultural landscapes. The dramatic decline in agrobiodiversity calls for strategies to reconcile production and biodiversity goals on the basis of sound knowledge about the determinants of farmland biodiversity. Based on surveys of the arable flora on 240 conventional maize and winter cereal (wheat and barley) fields in two regions of Germany, we assessed the importance of a large number of management, environmental and spatial predictors for arable plant abundance, species richness and community composition. All conventionally managed fields had very low plant diversity (3-6 species $100 \mathrm{~m}^{2}$ ). A complete model with all examined factors explained 40 and $32 \%$ of the variation in species richness and 42 and $36 \%$ of the variation in community composition for the field interior and the field margin, respectively. The choice of crop and other management factors (sowing date, fertilisation, herbicide use and crop rotation) were identified as important predictors of arable plant diversity in contemporary fields. Our results show that unless agrochemical input is markedly reduced, the potential for increasing the floristic diversity of high-input cropland is small.
\end{abstract}




\subsection{Introduction}

Arable non-crop plants play a vital and diverse role in farmland ecosystems, extending beyond being merely detrimental crop competitors. They are the basis of the cropland food web and provide forage, shelter and habitats for reproduction for a wide range of insects, birds and mammals (Marshall et al., 2003; Parish et al., 2009). It has also been shown that arable plants support beneficial arthropods that aid in suppressing pest populations (Altieri, 1999; Evans et al., 2011) and help to maintain favourable levels of plant-pollinator interactions in agricultural landscapes (Gabriel \& Tscharntke, 2007). In many Northern and Western European countries, where arable plants are confronted with a continuous process of intensification of field management since the middle of the $20^{\text {th }}$ century, arable plant diversity has been decreasing rapidly (Sutcliffe \& Kay, 2000; Fried et al., 2009; Meyer et al., 2013). Many studies have shown that farming without herbicides and with reduced amounts of fertiliser input (i.e. organic farming or traditional low-input farming practices) benefits arable plant diversity and supports associated ecosystem services, such as pollinator and pest predator communities (Hole et al., 2005; Kleijn et al., 2009). Yet in many cases, yields and revenues from conventionally managed, high-input fields are higher (Seufert et al., 2012), and calls to seek opportunities for enhancing arable plant diversity and abundance without compromising crop yields remain common. While reconciling these two goals might seem contradictory in the light of standard models of yield loss and weed density (Cousens, 1985), a better understanding of the abiotic and biotic controls of arable plant communities can potentially highlight new ways for an integrated weed management. The Resource Pool Diversity Hypothesis of Smith et al. (2010), for instance, postulates that diverse soil resource pools can decrease the competition between weeds and crops and allow for higher weed abundance without reducing crop yields. In this study, we aimed at disentangling the complex interaction between environmental (soil, climate) and management-related factors (crop type, phenology, cultivation practices, fertilisation, herbicide use) in their effect on the diversity and composition of arable plant assemblages in the interior and at the margin of conventionally managed maize and winter cereal (wheat and barley) fields. A better understanding of the key factors determining biodiversity on agricultural land can potentially be used to optimise strategies for enhancing arable plant diversity without compromising production goals.

The term "plant diversity" is used here to summarize different characteristics of plant assemblages and is not restricted to simply assessing the number of species. The influence of different management and environmental factors can be expected to vary between diversity metrics (Fried et al., 2008). To address different aspects of arable plant diversity, we assessed the effects of field management and environmental factors on weed cover, species richness and community composition. Whereas the latter two have been assessed by previous studies (Andreasen and Scovgaard, 2009; Fried et al., 2008; Lososová et al., 2004; Pinke et al., 2012 and references therein), weed cover has only rarely been investigated (Pyšek et al., 2005) despite being a crucial factor for farmland management decisions. A 
sufficiently dense weed cover composed of a diverse set of species with different traits implies more resources for a wider range of consumers and decomposers than mono-specific crop stands (which might nevertheless provide the same or even higher total biomass) (Marshall et al., 2003). At the same time, a higher weed cover negatively affects crop growth and yields and is therefore unfavourable from the crop production perspective (Cousens, 1985; Smith et al., 2009; Tang et al. 2014). Ideally, weed management at a regional scale would aim at maintaining high species richness and the complete set of regionally adapted arable plant assemblages while reducing weed cover to a level which balances the need to provide enough resources for maintaining functional pollinator and pest-predator communities with the objective to minimise yield loss (Marshall et al., 2003; Smith et al., 2009; Tang et al. 2014).

We expect management practices such as herbicide treatments, fertilisation, tillage, crop rotation and land use history to strongly influence all three response variables. Several studies investigated the impact of sowing date, tillage and N-fertilisation (Fried et al., 2008; Kleijn et al., 2009; Lososová et al., 2004; Pinke et al., 2012), but none of these studies examined the complete range of fertiliser applications, herbicide use intensity and aspects of crop rotation in their effect on the biological diversity of agricultural ecosystems.

Herbicide treatments aim at reducing weed cover and can also influence species richness and community composition by eradicating certain species completely and consequently fostering others (Délye, 2005; Owen, 2008). Both the overall intensity of herbicide applications and the types of active ingredients can be expected to determine these effects (Menne and Köcher, 2012). Herbicides can be classified according to their sites of action (SoA) as proposed by the Herbicide Resistance Action Committee (HRAC, Menne and Köcher, 2012). We expect herbicides targeted at a certain SoA to differ in their effectiveness in eradicating certain species and to most strongly affect a similar set of species (Délye, 2005, Owen, 2008, Nagai and Taya, 2015). This leads to the hypothesis that certain HRAC groups of herbicides have stronger effects on plant diversity than others and that a dosedependent response between the three investigated diversity metrics and the herbicides of certain HRAC group exists.

$\mathrm{N}$ fertilisation is known to increase the competitive ability of the crop and to favour certain weed species, whereas it negatively affects species preferring less nutrient-rich soils (Kleijn and van der Voort, 1997; Pyšek and Lepš, 1991; Tang et al. 2014). P, K and S fertilisation without N input has been shown to more strongly favour weed than crop biomass (Grant et al., 2007; Tang et al. 2014). Consequently, we formulate the hypotheses that crop cover increases with $\mathrm{N}$ fertilisation, whereas weed cover and species richness decrease and the community composition shifts. The effects of $\mathrm{P}, \mathrm{K}$ and $\mathrm{S}$ fertilisation are expected to vary depending on $\mathrm{N}$ fertilisation. 
Mouldboard ploughing reduces weed abundance and has been found to reduce weed cover, but to have only little effect on species richness (Ball, 1992; Teasdale et al., 1991). Depending on the timing of ploughing it can, however, be expected to influence community composition (Ball, 1992). This leads to the hypothesis that weed cover and community composition are mostly affected by deep ploughing, whereas species richness is not.

We also hypothesise that land use history and crop rotation will have strong impacts on community composition through their longer term influence on the seedbank (Ball, 1992). With regard to weed cover and species richness we expect these effects to be overridden by the more immediate effects of chemical and mechanical weed control.

Previous studies on the effects of field management on arable plant assemblages in conventional fields have found the current and, to a lesser extent, also the preceding crop type to be major drivers of arable plant species richness and community composition (Andreasen and Scovgaard, 2009; Fried et al., 2008; Lososová et al., 2004; Pinke et al., 2012). We expect the factor crop type to represent information about crop-specific management practices relating to the timing, type and quantity of cultivation, fertilisation and herbicide use.

In accordance with results by Fried et al. (2008) and Lososová et al. (2004), we expect community composition to be affected by macro-environmental factors, such as soil and climate conditions and by micro-environmental parameters such as slope, aspect and crop cover regulating, for instance, radiation input and water availability. Management practices will also affect community composition, but the effects can be regarded as secondary, i.e. acting on the community within the limits of their suitable environmental envelope. Weed cover and species richness are expected to be more strongly determined by the immediate effects of management practices and to a lesser extent by environmental factors than community composition.

Available studies also indicate that the relative importance of environmental factors with regard to field management can be expected to be higher if gradients are larger, i.e. at cross-regional or nationwide scales (Cimalová and Lososová, 2009; Fried et al., 2008; Pinke et al., 2012). The present study encompasses relatively small gradients in climate and soil variables as compared to previous assessments (Andreasen and Scovgaard, 2009; Fried et al., 2008; Lososová et al., 2004; Pinke et al., 2012). We therefore expect the relative importance of management vs. environmental factors to be high as compared to these assessments. As field margins are in contact with adjacent habitats (Marshall and Arnolds, 1995) and commonly receive less fertiliser and herbicide input (Wilson and Aebischer, 1995), we also expect the importance of field management factors to decreases towards the field edge (Pinke et al., 2012).

These hypotheses can be summed up under the following main research questions: 
1) What is the relative importance of management factors vs. environmental factors for arable plant diversity in conventional cropping systems at a regional scale?

2) Which management factors have the largest influence on arable plant diversity and how are they interacting with other management, environmental and spatial factors?

3) How important is the choice of crop for arable plant diversity in modern cropping systems and how does this factor interact with other management factors? What are the main differences in field management between the three studied crops?

\subsection{Methods}

\subsubsection{Study areas}

Two regions in Central Germany, the Lower Saxon hills (LS, $1118 \mathrm{~km}^{2}$ ) and the Thuringian Basin (TB, $1058 \mathrm{~km}^{2}$ ), were chosen as study regions (Fig. 2.1). The climate in the Thuringian Basin is more continental, i.e. drier and slightly warmer than in the Lower Saxon hills (mean annual precipitation: LS $650 \mathrm{~mm}$, TB 500-550 mm; mean annual temperature: LS $8.7{ }^{\circ} \mathrm{C}$, TB $9.2{ }^{\circ} \mathrm{C}$ ). Both regions share a long history of arable farming (since the Neolithic) due to the presence of highly fertile loess soils.

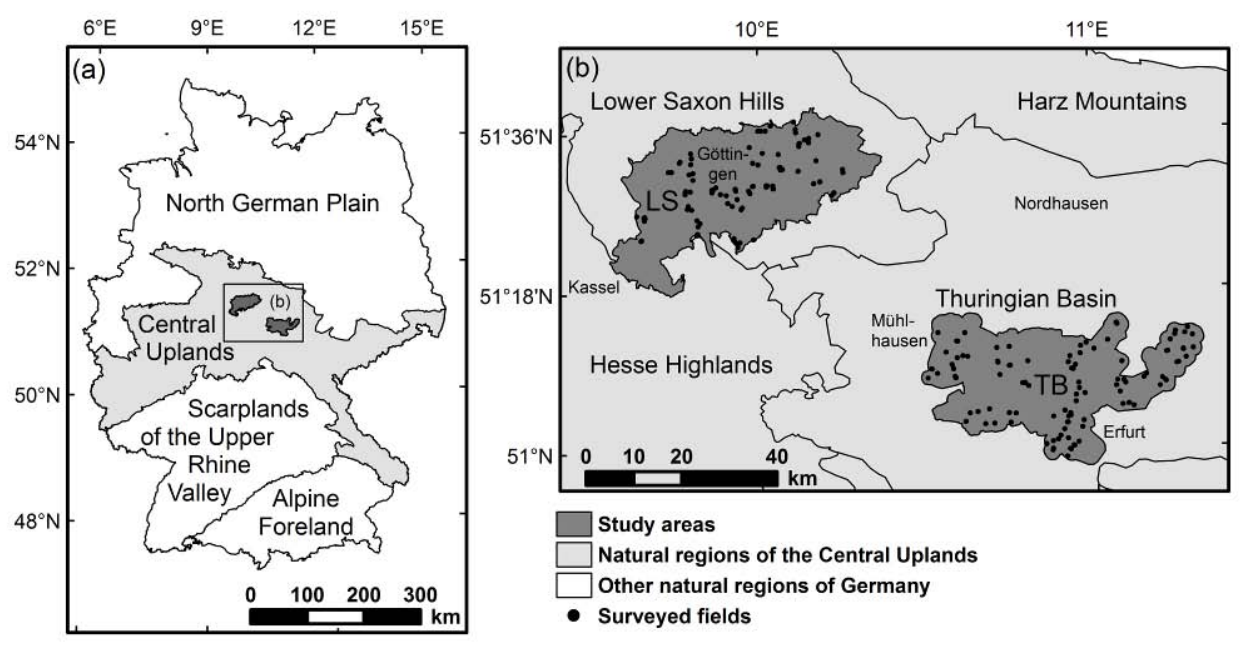

Fig. 2.1 Location (a) of the two study regions (LS = Lower Saxon hills, TB = Thuringian Basin) in Germany and (b) of the surveyed fields within the study regions (95 fields in LS, 111 fields in TB). The map is based on Universal Transverse Mercator (UTM) projection, zone 32 N (WGS 1984). Biogeographical boundaries were adopted from Meynen \& Schmithüsen (1953-1962). 
Arable land represents $43 \%$ of the total area in the Lower Saxon hills and $78 \%$ of the area in the Thuringian Basin. Today's crop rotations in both study regions are dominated by the winter-sown crops wheat, barley and oilseed rape (approximately 2/3 of the arable land (LWA Leinefelde-Worbis, 2011; LWA Sömmerda, 2011; LWK Niedersachsen, 2010). Silage maize for fodder or energy use was cultivated on 6-7\% of the arable land (LWA Leinefelde-Worbis, 2011; LWA Sömmerda, 2011; LWK Niedersachsen, 2010).

\subsubsection{Sampling design}

Twenty conventionally managed fields were surveyed per crop (maize, winter-sown wheat, winter-sown barley), sampling year (2011 or 2012) and study region, yielding a total of 240 surveyed fields. Farmers were selected with the aim to achieve full geographical coverage of the study regions, but were otherwise contacted at random without regard to farm size. Fields were randomly selected from the pool of fields offered by the participating farmers, with the condition of a minimum distance of $2 \mathrm{~km}$ between surveyed fields of the same crop within a sampling year. This high threshold ensures that direct dispersal events will only occur extremely rarely as most dispersal takes place within distances <200 m (Bergelson et al., 1993). On each field, two plots of $2 \mathrm{~m} \times 50 \mathrm{~m}$ size were surveyed. One plot was located parallel to the field margin starting with the first sown row of crops. The second one was placed parallel to the first plot and at least $10 \mathrm{~m}$ away from the field. Vegetation surveys and soil sampling took place between 26 May and 8 August 2011 and 2012. Sampling started within the barley fields which are the first to be harvested, then gradually shifted towards wheat fields and finished with the maize fields which are harvested last.

\subsubsection{Sampling of arable weed assemblages}

Within each $100 \mathrm{~m}^{2}$ sampling plot, all arable plant species and their respective covers were estimated using the Braun-Blanquet cover abundance scale consisting of nine classes $(\mathrm{r},+, 1,2 \mathrm{~m}, 2 \mathrm{a}$, 2b, 3, 4, 5) according to Wilmanns (1998). Additionally, total crop cover and total weed cover were estimated visually. A complete species list is given in appendix 2.A.

\subsubsection{Soil sampling and analyses}

Soil samples were taken at four random locations within each vegetation sampling plot from the uppermost $10 \mathrm{~cm}$ of the soil column after removing the litter using a soil corer of $5.1 \mathrm{~cm}$ diameter. The four samples per plot were thoroughly mixed and stored at $4{ }^{\circ} \mathrm{C}$. The $\mathrm{pH}$ was measured according to HFA (2005). The base saturation ( $\left[\mathrm{Ca}^{2+}, \mathrm{Mg}^{2+}, \mathrm{K}^{+}\right] /\left[\mathrm{Ca}^{2+}, \mathrm{Mg}^{2+}, \mathrm{K}^{+}, \mathrm{Al}^{3+}, \mathrm{Mn}^{2+}, \mathrm{Fe}^{2+}, \mathrm{H}^{+}\right]$, in \%) was calculated from an analysis of the effective cation-exchange capacity via percolation with $\mathrm{BaCl}_{2}$ 
solution $\left(0.1 \mathrm{~mol} \mathrm{~L}^{-1}\right)$ and inductively coupled plasma (ICP) analysis of element concentrations in the percolate based on methods described in HFA (2005). The concentration of plant-available phosphorus was estimated with anion-exchange resin bags (Sibbesen, 1977). The amount of extracted $\mathrm{P}$ was measured colourimetrically with the molybdate/ascorbic acid method. The total amount of carbon $\left(\mathrm{C}_{\text {tot }}\right)$ and nitrogen $\left(\mathrm{N}_{\mathrm{tot}}\right)$ and the $\mathrm{C} / \mathrm{N}$-ratio of the samples were determined with a $\mathrm{C} / \mathrm{N}$ elemental analyser (vario EL III, Elementar, Hanau, Germany). To detect the concentration of organic carbon $\left(\mathrm{C}_{\text {org }}\right)$, samples were heated to $450{ }^{\circ} \mathrm{C}$ to burn all organic carbon. Subsequently, the amount of the remaining inorganic carbon was measured and subtracted from the total carbon $\left(\mathrm{C}_{\text {tot }}\right)$ concentration. An estimate of the soil organic matter content (in \%) was obtained by multiplying $\mathrm{C}_{\text {org }}$ with the factor 1.72 .

\subsubsection{Derivation of environmental, management and spatial variables}

\subsubsection{Management variables}

A concise summary of all investigated management variables is given in Table 2.1. For each surveyed field, the participating farmers answered a standardised questionnaire (appendix 2.B). They were asked to provide information on land use history, on the crops and catch crops planted during the ten years prior to the survey, on the amount, timing and kind of fertilisation, herbicide applications and tillage operations during the year of survey (syr) and during the preceding year (pyr). Due to incomplete or inconsistently filled questionnaires, 34 fields had to be excluded from further analyses, resulting in a total of 206 sampling units (71 maize fields, 71 wheat fields and 64 barley fields).

Herbicide applications were found to involve a wide range of products and active ingredients. To reduce the complexity of this information, we derived the herbicide use intensity index (HI, eq. 2.1) as proposed by Roßberg et al. (2002). For each field, HI was obtained by summing up the products of the proportion of the field area sprayed ( $\mathrm{p}_{\text {area }}$ ) and the actually applied fraction of the maximum admitted application rate $\left(\mathrm{p}_{\mathrm{rate}}\right)$ for each herbicide. The factor $\mathrm{p}_{\text {area }}$ was usually set to 1 , as the treatments generally affected the entire sampling plots. In few cases, where only part of the field was sprayed, the factor $\mathrm{p}_{\text {area }}$ was used to minimise potential bias.

$$
\mathrm{HI}=\sum\left(\mathrm{p}_{\text {area }} * \mathrm{p}_{\text {rate }}\right)
$$

All herbicides were also classified by the sites of action of their active ingredients according to the classification system of the Herbicide Resistance Action Committee (HRAC) (Menne and Köcher, 2012; appendix 2.C). The amount of applied herbicide within each HRAC group (in $\mathrm{kmol} \mathrm{ha}^{-1}$ ) was determined for each field and summed up for the study year and the previous year. 
Table 2.1 Description of predictors used for the analyses in the nine sets of variables. If correlations with $\mathrm{R}>0.5$ were found for a predictor, the correlated variables are given. Syr $=$ year of survey, pyr $=$ preceding year. Details on the categories of soil type, geological substrate and the HRAC classification are given in appendix 2.C.

\begin{tabular}{|c|c|c|c|c|}
\hline Group & $\begin{array}{l}\begin{array}{l}\text { Set of } \\
\text { variables }\end{array} \\
\end{array}$ & Variable & Description & $\begin{array}{l}\text { Correlations } \\
\text { with } \mathrm{R}>0.5 \\
\end{array}$ \\
\hline \multirow{3}{*}{$\begin{array}{l}\text { Environmental } \\
\text { factors }\end{array}$} & $\begin{array}{l}\text { Macro } \\
\text { environment }\end{array}$ & $\begin{array}{l}\text { Region } \\
\text { Elevation } \\
\text { Precipitation } \\
\text { Temperature } \\
\text { Sunshine hours }\end{array}$ & $\begin{array}{l}\text { Study region }(\mathrm{LS} \text { or TB })^{\mathrm{a})} \\
\text { Elevation [m a.s.l.] } \\
\text { Mean precipitation during veget. period } \\
{[\mathrm{mm}]} \\
\text { Mean temperature during veg. period }\left[{ }^{\circ} \mathrm{C}\right] \\
\text { Mean \# of sunshine hours during veget. } \\
\text { period [h] }\end{array}$ & $\begin{array}{l}\text { Precip., sunsh. h. } \\
\text { Temp., precip. } \\
\text { Region, elev., } \\
\text { temp., precip. } \\
\text { Elev., precip. } \\
\text { Region, precip. }\end{array}$ \\
\hline & $\begin{array}{l}\text { Micro } \\
\text { environment }\end{array}$ & $\begin{array}{l}\text { Slope } \\
\text { Aspect } \\
\text { Crop cover } \\
\text { Tree/shrub cover }\end{array}$ & $\begin{array}{l}\text { Slope }\left[{ }^{\circ}\right] \\
0=(\mathrm{NW}, \mathrm{NNW}, \mathrm{N}, \mathrm{NNE}, \mathrm{NE}) \\
0.5=(\mathrm{ENE}, \mathrm{E}, \mathrm{ESE}, \mathrm{WNW}, \mathrm{W}, \mathrm{WSW}) \\
1=(\mathrm{SW}, \mathrm{SSW}, \mathrm{S}, \mathrm{SSW}, \mathrm{SE}) \\
\text { Total crop cover per plot }[\%] \\
\text { Total tree/shrub cover }[\%], \text { only at field } \\
\text { edge }\end{array}$ & - \\
\hline & Soil & $\begin{array}{l}\text { Geological substrate } \\
\text { Soil type } \\
\text { pH } \\
\log (\mathrm{BS}) \\
\mathrm{C} / \mathrm{N} \text { ratio } \\
\text { SOM } \\
\mathrm{P} \\
\end{array}$ & $\begin{array}{l}16 \text { categories } \\
16 \text { categories } \\
\mathrm{pH}\left(\text { in } \mathrm{H}_{2} \mathrm{O}\right) \\
\log (1-\text { base saturation }) \\
\mathrm{C} / \mathrm{N} \text { ratio }\left[\mathrm{g} \mathrm{g}^{-1}\right] \\
\text { Soil organic matter content }[\%] \\
\text { Plant-available } \mathrm{P}\left[\mu \mathrm{mol} \mathrm{P} \mathrm{g}_{\left(\text {dry weight }^{-1}\right]}\right]\end{array}$ & $\begin{array}{l}- \\
- \\
- \\
- \\
- \\
- \\
-\end{array}$ \\
\hline \multirow{6}{*}{$\begin{array}{l}\text { Management } \\
\text { factors }\end{array}$} & Crop & $\begin{array}{l}\text { Crop }_{\text {syr/pyr }} \\
\text { Catch crop } \\
\text { syr/pyr } \\
\text { Sowing date }\end{array}$ & $\begin{array}{l}\text { Current (syr) or preceding crop (pyr) } \\
\text { Binary }(\mathrm{y} / \mathrm{n}) \text { : Catch crop prior to main } \\
\text { crop? } \\
\text { Sowing date given as \# of weeks after } \\
\text { August } 1\end{array}$ & $\begin{array}{l}\text { Sowing date } \\
\text { - } \\
\text { Crop }_{\text {syr }}\end{array}$ \\
\hline & Fertilisation & $\begin{array}{l}\mathrm{N}, \mathrm{P}, \mathrm{K}, \mathrm{S}, \mathrm{Mg}(\text { each } \\
\text { for syr \& pyr) } \\
\log (\mathrm{Ca})_{\mathrm{syr}}, \log (\mathrm{Ca})_{\mathrm{pyr}}\end{array}$ & $\begin{array}{l}\text { Amount of N, P, K, S, Mg fertilisation } \\
{\left[\mathrm{kg}^{* h^{-1}}\right]} \\
\text { logarithm of Ca fertiliser amount } \\
{\left[\mathrm{kg} \mathrm{ha}^{-1}\right] ;(\log (\mathrm{Ca}+0.1))}\end{array}$ & $\begin{array}{l}\mathrm{K} \& \mathrm{P} ; \mathrm{K} \& \mathrm{Mg} ; \\
\mathrm{Mg} \& \log (\mathrm{Ca}) ; \text { in } \\
\text { the resp. year } \\
\mathrm{Mg}_{\text {syr }} \\
\mathrm{Mg}_{\mathrm{pyr}}\end{array}$ \\
\hline & Herbicides & $\begin{array}{l}\mathrm{HI}_{\text {syr/pyr }} \\
\text { \# of mech. of } \\
\text { action } \\
\text { syr/pyr } \\
\text { A, B, C } C_{1}, C_{2}, C_{3}, E \\
\mathrm{~F}_{1}, \mathrm{~F}_{2}, \mathrm{~F}_{3}, \mathrm{~F}_{4}, \mathrm{G}, \mathrm{K}_{1} \\
\mathrm{~K}_{3}, \mathrm{~N}, \mathrm{O}^{\mathrm{b})}\end{array}$ & $\begin{array}{l}\text { Herbicide use intensity index (see } \\
\text { Methods section) } \\
\text { Number of mechanisms of action of } \\
\text { herbicides used (see Methods section) } \\
\text { Amount of herbicide from the respective } \\
\left.\text { HRAC group [1000 mol ha }{ }^{-1}\right] \text {, sum of syr } \\
\& \text { pyr }\end{array}$ & $\begin{array}{l}\text { \# of mechanisms } \\
\text { of action } \\
\text { syr/pyr } \\
\mathrm{HI}_{\text {syr/pyr }} \\
\mathrm{C}_{1} \text { with prop. of } \\
\text { maize \& winter- } \\
\text { sown crops }\end{array}$ \\
\hline & $\begin{array}{l}\text { Conversion } \\
\text { tillage }\end{array}$ & $\begin{array}{l}\text { Ploughed last } 2 \text { yrs } \\
y / n \\
\text { Ploughed last } 5 \text { yrs } \\
\text { y/n }\end{array}$ & $\begin{array}{l}\text { Binary }(\mathrm{y} / \mathrm{n}) \text { : Deep ploughed during } 2 \\
\text { years prior to survey? } \\
\text { Binary }(\mathrm{y} / \mathrm{n}) \text { : Deep ploughed during } 5 \\
\text { years prior to survey? }\end{array}$ & - \\
\hline & $\begin{array}{l}\text { Crop } \\
\text { rotation }(10 \\
\text { years prior } \\
\text { to survey) }\end{array}$ & $\begin{array}{l}\text { \# of crops } \\
\text { Prop. of } \\
\text { maize/wheat/winter } \\
\text { crops/legumes/fallow } \\
\text { \& grassland/biennial } \\
\text { \& perennial crops }\end{array}$ & $\begin{array}{l}\text { Number of different crops in crop rotation } \\
\text { Proportion of years with maize/winter- } \\
\text { sown wheat/winter-sown } \\
\text { crops/legumes/fallow \& } \\
\text { grassland/biennial \& perennial crops [\%] }\end{array}$ & $\begin{array}{l}\text { Maize \& wheat \& } \\
\text { winter crops \& } \\
\mathrm{C}_{1} ; \text { fallow }+ \\
\text { grassland \& } \\
\text { biennials }+ \\
\text { perennials }\end{array}$ \\
\hline & $\begin{array}{l}\text { Land use } \\
\text { history }\end{array}$ & $\begin{array}{l}\text { Years since } \\
\text { conversion to } \\
\text { cropland } \\
\text { Previous land use }\end{array}$ & $\begin{array}{l}\frac{4 \text { categories: }}{50 ;>50 \text { years }} \leq 10 ;>10 \& \leq 30 ;>30 \& \leq \\
\frac{6 \text { categories: permanent grassland, fallow }}{\text { land, vegetables, fruit trees, forest, }} \\
\text { unknown }\end{array}$ & - \\
\hline
\end{tabular}




\subsubsection{Environmental variables}

The mean air temperature, the mean precipitation and the mean number of sunshine hours during the vegetation period (March - September) were obtained for each plot from spatially explicit data (resolution $1 \times 1 \mathrm{~km}$ ) based on long-term means for the period 1971-2000 (DWD, 2013). Elevation above sea level (a. s. 1.) was derived from the digital elevation model for Germany (resolution: extent $25 \times 25 \mathrm{~m}$, height $0.1 \mathrm{~m})(\mathrm{BKG}, 2005)$. Variables characterising the local environment on the plots (slope, aspect, crop cover and tree/shrub cover; termed 'micro environment' hereafter) were determined directly in the field. In addition to the measured soil chemistry variables, soil and geological maps of the study areas (LS - BÜK50, GK50; Boess et al., 2004; LBEG, 2010; TB - 'Thuringian soil geological map'; Rau et al., 2000) were used to identify the dominant soil type and the geological substrate for each plot (appendix 2.C).

\subsubsection{Spatial factors}

The spatial variables were derived from the geographical coordinates (coordinate system UTM zone 32 N, WGS 1984) using principal coordinates of neighbour matrices (PCNM). These spatial variables are calculated as principal components of a truncated matrix of Euclidian distances between sampling sites (Borcard and Legendre, 2002). PCNM variables are able to fully represent all spatial relations within a given spatially explicit data set and can be used to correct for spatial autocorrelation (Borcard and Legendre, 2002). We used the pcnm function of the R-package vegan ( $\mathrm{R}$ version 3.0.1) and applied a truncation threshold of $40 \mathrm{~km}$. The threshold of $40 \mathrm{~km}$ was obtained as the longest distance in the minimum spanning tree of the matrix of Euclidian distances (rounded; Borcard and Legendre, 2002). After pre-selecting all spatial variables with $p \leq 0.2$ for each response variable, backward selection was applied to identify PCNM variables with $p \leq 0.05$ (R-package vegan, functions rda, ordistep) to be included in further analyses (Borcard \& Legendre, 2002).

\subsubsection{Statistical analyses}

\subsubsection{Model selection and variation partitioning}

All statistical analyses were performed using R (versions 2.11.1 and 3.0.1; R Development Core Team, 2010). The crop itself, any woody species (including Rubus fruticosus agg.) and representatives of volunteer grain (Brassica napus, Hordeum vulgare, Triticum aestivum, Secale cereale and $\times$ Triticosecale) were not included in the analyses of species richness and community composition. The environmental and management variables were allocated to one of nine subject-specific sets of variables (environmental variables: macro environment, micro environment, soil; management variables: crop, fertilisation, herbicides, conversion tillage using a mouldboard plough, crop rotation and land use history, Table 2.1). All variables were tested for collinearity (within and between sets). The variable "sowing date" was very strongly correlated to the crop type and was therefore excluded 
from the analyses. Further correlations were found to occur only within certain sets of variables. If a large number of variables of a set was highly correlated (as occurred for macro environment, fertilisation and crop rotation), the axes of a principal components analysis (PCA) were used as variables instead. The first two axes ( $\mathrm{PC} 1$ - increasing precipitation and decreasing temperature, $\mathrm{PC} 2$ - decreasing elevation, together explaining $96 \%$ of the total variation; appendix 2.D) were used for characterising the macro environment, and the first four axes for fertilisation (PC1 - decreasing application of organic fertilisers including N, P, K, Ca, Mg, PC2 - gradient of S fertilisation, PC3 increasing $\mathrm{Ca}$ and $\mathrm{Mg}$ fertilisation and decreasing $\mathrm{P}$ input, $\mathrm{PC} 4$ - gradient of $\mathrm{N}$ fertilisation; together explaining 88\%) and crop rotation (PC1 - intensity gradient: decreasing proportion of winter crops and increasing proportion of perennial crops and fallow, PC2 - decreasing proportion of maize, PC3 decreasing number of crops, PC4 - decreasing proportion of legumes, explaining $92 \%$ of the variation; appendix 2.D).

Full models were derived for each set of variables based on theoretical reflections about potential mechanisms acting on arable plant diversity (appendix 2.D). Subsequently, a backward selection process (R-package vegan, function ordistep) was used and only variables which contributed significantly $(\mathrm{p} \leq 0.05)$ were retained in the final models (Table 2.2). (Partial) multiple linear regression models were calculated for the response variables total cover of arable non-crop plants ('weed cover') and species richness per plot (R-package vegan, function $r d a$, Oksanen et al., 2013). All models were checked visually for normality of residuals and homogeneity of variances. The total weed cover was log-transformed before the analyses to avoid problems with heteroscedasticity. For quantifying the effects on community composition, we applied (partial) redundancy analyses (Rpackage vegan, function $r d a$ ). Beforehand, a Hellinger transformation was applied to the matrix of species abundances per plot to avoid problems with long gradients resulting in many zeros in the data set (Legendre and Gallagher, 2001). In all models, the effects of sampling year and spatial autocorrelation (all significant PCNM variables) were partialled out to account for effects inherent to the sampling design.

The final models (Table 2.2) were used to obtain the 'gross' effect of each set of variables. 'Net' effects were calculated by modelling the explanatory power of each set of variables while partialling out the effects of all other significant variables from the reduced models (Legendre, 2008). We always reported adjusted $\mathrm{R}^{2}$ (Peres-Neto et al., 2006). Variation that was explained by the model containing the significant variables from all sets but that could not be attributed to a single set of variables was called 'shared variation' (Legendre, 2008). By summing up the gross effects of the pertinent sets of variables, the maximum amount of variation explained by environmental, management or spatial factors was determined. A certain fraction of the total shared variation could be attributed to each of these three groups of factors by subtracting the maximum amount explained by the other two groups 
of factors minus the net amount explained by each pertinent set of variables from the total amount of shared variation.

Table 2.2 Final models for each of the six response variables sorted by the nine sets of predictors. Variables from Table 2.1 were only retained in the model if they contributed significantly $(p \leq 0.05)$. In all models, the year of survey and the significant PCNM variables were included as co-variables to correct for differences between sampling year and spatial autocorrelation.

\begin{tabular}{|c|c|c|}
\hline & Final models after backward selection & \\
\hline Weed cover & Field interior & Field margin \\
\hline Crop & crop $_{\text {syr }}$ & - \\
\hline Fertilisation & $\mathrm{PC} 1_{\mathrm{syr}} * \mathrm{PC} 1_{\mathrm{pyr}}+\mathrm{PC} 2_{\mathrm{syr}}+\mathrm{PC} 2_{\mathrm{pyr}}$ & $\mathrm{PC} 2_{\text {syr }}+\mathrm{PC} 2_{\mathrm{pyr}}$ \\
\hline Herbicides & $\mathrm{C} 3+\mathrm{F} 2+\mathrm{K} 1$ & - \\
\hline Conversion tillage & - & - \\
\hline Crop rotation & $\mathrm{PC} 1$ & - \\
\hline Land use history & time since conversion to cropland & - \\
\hline Macro environment & - & - \\
\hline Micro environment & - & - \\
\hline Soil $\quad+\quad-\quad$ & soil type + SOM & $\mathrm{pH}$ \\
\hline Spatial factors & 6 significant PCNMs & 15 significant PCNMs \\
\hline \multicolumn{3}{|l|}{ Species richness } \\
\hline Crop & crop $_{\text {syr }}$ & crop $_{\text {syr }}$ \\
\hline Fertilisation & $\mathrm{PC} 1_{\mathrm{syr}}+\mathrm{PC} 2_{\mathrm{syr}}+\mathrm{PC} 2_{\mathrm{pyr}}+\mathrm{PC} 3_{\mathrm{syr}} * \mathrm{PC} 3_{\mathrm{pyr}}$ & $\mathrm{PC} 2_{\mathrm{pyr}}$ \\
\hline Herbicides & $\mathrm{C} 1+\mathrm{K} 3$ & - \\
\hline Conversion tillage & - & - \\
\hline Crop rotation & - & - \\
\hline Land use history & - & - \\
\hline Macro environment & - & - \\
\hline Micro environment & - & crop cover \\
\hline Soil & - & geological substrate $+\mathrm{pH}+\mathrm{SOM}$ \\
\hline Spatial factors & 10 significant PCNMs & 4 significant PCNMs \\
\hline \multicolumn{3}{|c|}{ Community composition } \\
\hline Crop & crop $_{\text {syr }}$ & crop $_{\text {syr }}$ \\
\hline Fertilisation & $\mathrm{PC} 1_{\mathrm{syr}}+\mathrm{PC} 2_{\mathrm{syr}}+\mathrm{PC} 3_{\mathrm{syr}}$ & $\mathrm{PC} 1_{\mathrm{syr}}+\mathrm{PC} 2_{\mathrm{syr}}$ \\
\hline Herbicides & $\mathrm{C} 1+\mathrm{G}$ & $\mathrm{B}+\mathrm{C} 1$ \\
\hline Conversion tillage & ploughing y/n (last 5 yrs) & - \\
\hline Crop rotation & $\mathrm{PC} 1+\mathrm{PC} 2+\mathrm{PC} 3$ & $\mathrm{PC} 1+\mathrm{PC} 2+\mathrm{PC} 3$ \\
\hline Land use history & time since conversion to cropland & - \\
\hline Macro environment & PC2 & $\mathrm{PC} 2$ \\
\hline Micro environment & - & slope*aspect + crop cover \\
\hline Soil & soil type*geological substrate $+\mathrm{P}$ & $\begin{array}{l}\text { soil type }+ \text { geological substrate }+\mathrm{pH}+ \\
\mathrm{C} / \mathrm{N} \text { ratio }+\mathrm{SOM}+\mathrm{P}\end{array}$ \\
\hline Spatial factors & 5 significant PCNMs & 8 significant PCNMs \\
\hline
\end{tabular}

\subsubsection{Comparisons between crops}

The non-parametric Behrens-Fisher-Test for multiple comparisons (R-package npmc, function npmc, Helms and Munzel, 2009) was used to test for differences in arable plant cover, species richness and the explanatory variables between the three different crops.

\subsubsection{Analysing the influence of crop type}

For analysing the influence of the current crop on arable plant diversity in more detail, we conducted a separate analysis including only those sets of management variables which contained 
variables showing significant differences between crops (fertilisation, herbicide use and crop rotation). Additionally, we added the variable sowing date, which had not been included in the previous analysis, to explore whether it was possible to discern which factor (current crop or sowing date) was more important. When interpreting the results the strong correlation between both variables was taken into account.

By combining the reduced models for each of these sets of variables, we obtained the maximum amount of variation explained by all potentially crop-related management parameters for all response variables. The gross and the net effects for each set of variables were calculated. We differentiated between the net effect of each set when partialling out all other variables (net $\left.{ }_{\text {all }}\right)$ and the net effect when partialling out the effect of the crop (net crop $_{\text {) }}$. We also calculated the net effect of the current crop while controlling for each of the other sets of variables one by one ( crop $\left._{\text {var }}\right)$.

\subsection{Results}

\subsubsection{General importance of management factors for arable plant diversity}

Arable plant diversity (weed cover, species richness and community composition) was found to be explained to a large extent by factors from all three factor groups (management, environmental and spatial factors). All factors together explained $32-43 \%$ of the total variation in weed cover, species richness and community composition (gross effects, $\mathrm{R}^{2}=0.32-0.43, \mathrm{R}^{2}$ adjusted $=0.13-0.34$ ) (Table 2.3). Field management factors were found to be important explanatory variables for the arable plant cover, the species richness per plot and the community composition (Fig. 2.2), accounting for 6-48\% of the total explained variation. At the field margins, the explanatory power of the management factors was by $49-86 \%$ smaller than in the field interior for the three response variables. Field management was more important than environmental factors when explaining variation in species richness (field interior) and in weed cover (field interior and margin), but it was less important for species richness at the field margin and for community composition in the interior and at the margin. Fertilisation was the only factor which showed a significant net effect on weed cover both at the field margin and in the field interior after correcting for spatial autocorrelation (Table 2.3).

The explanatory factors from different sets of variables interacted strongly and the net effects were usually much smaller than the gross effects. The proportion of explained variation, which could not be attributed to a certain group of variables (management, environment or spatial factors), varied between 2 and $25 \%$ of the total explained variation, while the share of variation not attributable to a certain set of variables within these groups varied between $0-30 \%$. 
Table 2.3 Gross and net effects $\left(\mathrm{R}_{\text {adjusted }}\right)$ of different sets of variables on weed cover, species richness and community composition in 206 fields in Central Germany. Note that only the significant variables from the final models (Table 2.2) have entered the analyses presented here. The number and kind of variables included in each set may differ between response variables. Please refer to table 2.2 for interpretation. For further details on the calculation see Methods section; ns $p>0.05 ; * p$ $\leq 0.05 ; * * \leq 0.01 ; * * * p \leq 0.001$.

\begin{tabular}{|c|c|c|c|c|c|c|c|c|c|c|c|c|}
\hline & \multicolumn{4}{|c|}{ Weed cover } & \multicolumn{4}{|c|}{ Species richness } & \multicolumn{4}{|c|}{ Community composition } \\
\hline & \multicolumn{2}{|c|}{ Field interior } & \multicolumn{2}{|c|}{ Field margin } & \multicolumn{2}{|c|}{ Field interior } & \multicolumn{2}{|c|}{ Field margin } & \multicolumn{2}{|c|}{ Field interior } & \multicolumn{2}{|c|}{ Field margin } \\
\hline & gross & net & gross & net & gross & net & gross & net & gross & net & gross & net \\
\hline Total & $30.8^{* *}$ & - & $34.3^{* *}$ & - & $32.9^{* *}$ & - & $23.7^{* *}$ & - & $14.2^{* *}$ & - & $12.7^{\text {** }}$ & - \\
\hline Crop & $8.8^{* \cdots}$ & $n s$ & ns & $n s$ & $9.5^{* \cdots}$ & $2.0^{3-1}$ & $3.9^{9 *}$ & $2.8^{*}$ & $0.6^{\cdots \cdots}$ & $n s$ & $0.9^{9 *}$ & $0.3^{* *}$ \\
\hline Fertilisation & $12.9^{* *}$ & $5.5^{* *}$ & $2.5^{* *}$ & $2.1^{*}$ & $9.2^{* * *}$ & $n s$ & $4.4^{* *}$ & $3.7^{*}$ & $0.7^{* *}$ & $n s$ & $0.5^{* *}$ & $n s$ \\
\hline Herbicides & $5.9^{* *}$ & $n s$ & $\mathrm{~ns}$ & $n s$ & $4.9^{* *}$ & $2.2^{*}$ & ns & $n s$ & $0.8^{* *}$ & $n s$ & $0.7^{\text {** }}$ & $0.3^{*}$ \\
\hline Conversion tillage & ns & $n s$ & ns & $n s$ & ns & $n s$ & $\mathrm{~ns}$ & $n s$ & $0.7^{* *}$ & $0.2^{*}$ & ns & $n s$ \\
\hline Crop rotation & $3.3^{* *}$ & $n s$ & ns & $n s$ & ns & $n s$ & ns & $n s$ & $1.4^{* *}$ & $n s$ & $1.1^{\text {*** }}$ & $0.5^{*}$ \\
\hline Land use history & $6.9^{* *}$ & $n s$ & ns & $n s$ & ns & $n s$ & $\mathrm{~ns}$ & $n s$ & $2.3^{*}$ & $1.4^{*}$ & ns & $n s$ \\
\hline Total management & $19.9^{* \cdots}$ & - & $2.5^{\text {wa }}$ & - & $13.3^{* *}$ & - & $8.9^{7 *}$ & - & $3.1^{* \cdots \cdots}$ & - & $1.9^{* \cdots \cdots}$ & - \\
\hline Macro environment & $\mathrm{ns}$ & $n s$ & $\mathrm{~ns}$ & $n s$ & ns & $n s$ & ns & $n s$ & $0.2^{*}$ & $n s$ & $0.3^{\text {wan }}$ & $n s$ \\
\hline Micro environment & $\mathrm{ns}$ & $n s$ & ns & $n s$ & ns & $n s$ & $2.3^{* *}$ & $n s$ & $\mathrm{~ns}$ & $n s$ & $1.1^{\text {** }}$ & $n s$ \\
\hline Soil & $5.9^{*}$ & $n s$ & $1.2^{*}$ & $n s$ & $\mathrm{~ns}$ & $n s$ & $8.5^{* *}$ & $6.4^{*}$ & $8.5^{* *}$ & $7.0^{*}$ & $6.9^{* *}$ & $5.6^{* *}$ \\
\hline Total environment & $5.9^{*-}$ & - & $1.2^{*}$ & - & $\mathrm{ns}$ & - & 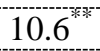 & - & $8.5^{* \cdots}$ & - & $7.2^{*}$ & - \\
\hline Spatial factors & $10.1^{* *}$ & $11.1^{*}$ & $31.2^{*}$ & $30.8^{*}$ & $20.1^{¥ *-1}$ & 19.1 & $7.3^{*-}$ & $3.5^{*}$ & $2.4^{* \cdots}$ & $1.7^{* 3}$ & $3.9^{9 *}$ & $2.8^{* *}$ \\
\hline
\end{tabular}




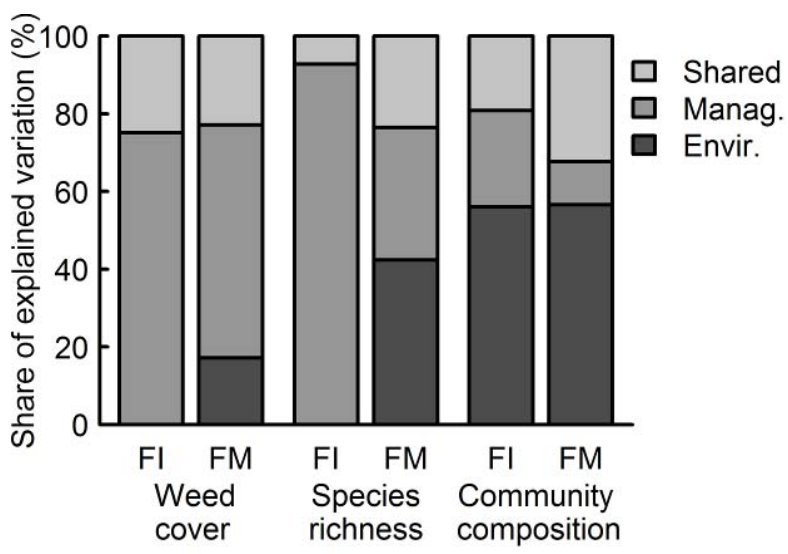

Fig. 2.2 Proportion of explained variation in arable plant cover, species richness and community composition attributable to field management and environmental factors in the interior (FI) and at the margin (FM) of 206 conventionally managed fields in Central Germany.

\subsubsection{Effects of specific management factors on arable plant diversity and interactions with environmental and spatial factors}

Within the group of management factors, current crop was identified as a significant explanatory factor for all response variables except weed cover at the field margin (Table 2.2). Neither the preceding crop nor the planting of catch crops were found to be significant factors for any of the response variables (Table 2.2).

In contrast, fertilisation during the year of survey and/or the preceding year was retained in the final models for all response variables (Table 2.2). We found both the amount of N, P, K, Ca and Mg (PC1) and $\mathrm{S}$ fertilisation (PC2) to be important explanatory factors (Table 2.2). Interestingly, the effect of $\mathrm{S}$ fertilisation persisted independently of the effects of other predictors and was found to be more important for weed cover and species richness than the other fertilisers (Table $2.2 \&$ 2.3, Fig. 2.3, 2.4a). $\mathrm{S}$ fertilisation in the year preceding the vegetation surveys was found to be positively correlated to weed cover and species richness (Fig. $2.3 \& 2.4 \mathrm{a}$ ). Even the relationship between weed cover and crop cover was found to be mediated by $\mathrm{S}$ fertilisation. Surprisingly, crop cover was just about not significantly correlated to weed cover accounting only for the effects of crop type, spatial autocorrelation and sampling year $\left(\mathrm{y}=-1.64 \mathrm{x} ; \mathrm{R}^{2}=0.02 ; \mathrm{p}=0.053\right)$. Only after additionally partialling out the effect of $\mathrm{S}$ fertilisation in the preceding year the relationship became significant as expected $\left(y=-1.83 x ; R^{2}=0.02 ; p=0.033\right)$. 


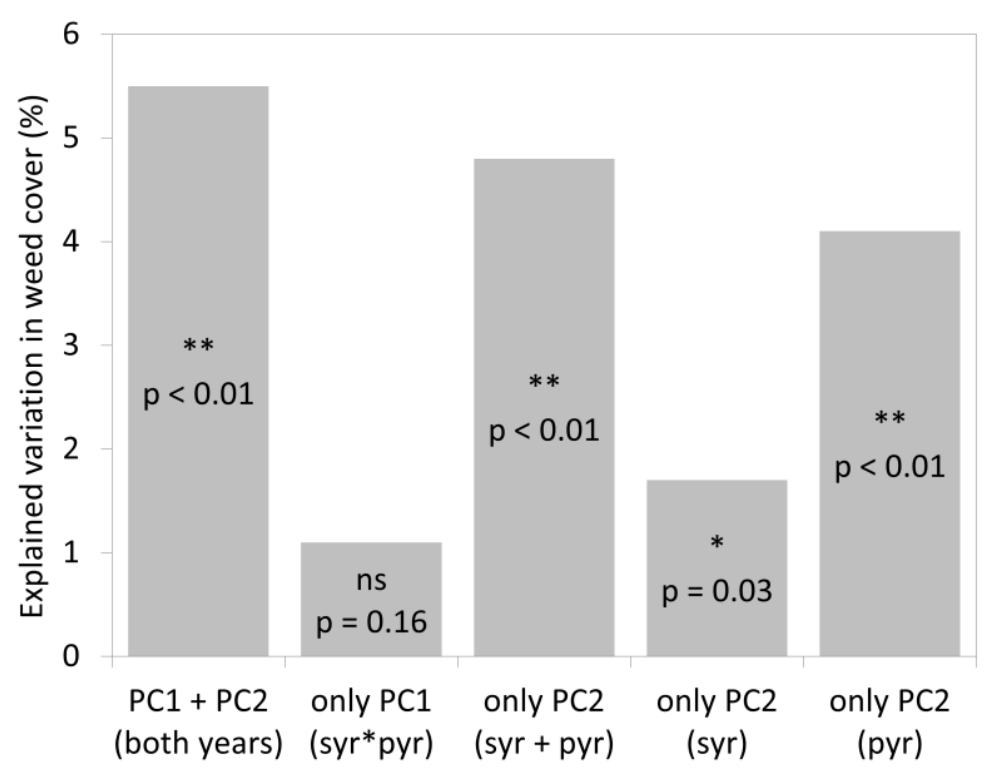

Fig. 2.3 Proportion of variance in weed cover in the field interior explained by fertilisation in the sampling year (syr) and in the preceding year (pyr). Fertilisation effects are represented as principal components (appendix 2.D). The bars show net effects after partialling out the effect of crop, sampling year and spatial autocorrelation. Only combinations of factors which were retained in the final models (Table 2.2) are presented here.
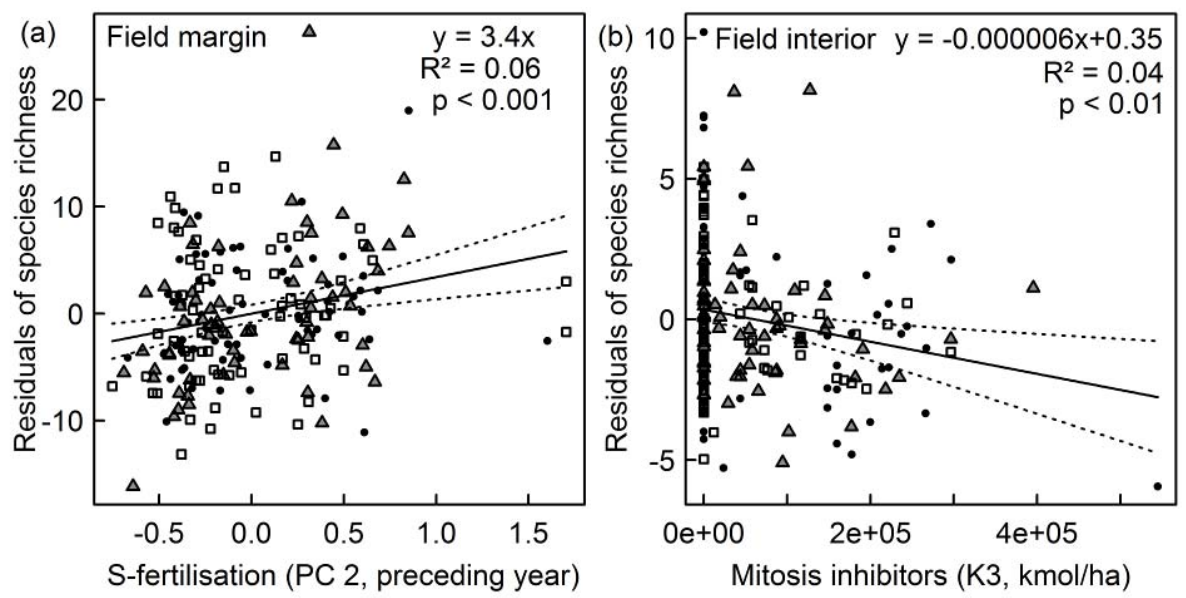

Fig. 2.4 Relationship between (a) species richness at the field margin and Sfertilisation during the preceding year and (b) species richness in the field interior and the amount of herbicides from class $\mathrm{K}_{3}$ (mitosis inhibitors) after partialling out the effects of crop, sampling year and spatial autocorrelation. The solid line represents the linear regression line while the dotted lines are the $95 \%$ confidence intervals. Black circles $=$ maize, white squares $=$ winter-sown wheat, grey triangles $=$ winter-sown barley. 
Certain groups of herbicides ( $\mathrm{B}, \mathrm{C}_{1}, \mathrm{C}_{3}, \mathrm{~F}_{2}, \mathrm{G}, \mathrm{K}_{1}$ and $\mathrm{K}_{3}$, cp. Table $2.2 \& 2.3$, Fig. 2.4b) also explained part of the variation for all response variables. The effect on weed cover and species richness was, however, restricted to the field interior. A significant net effect of the use of inhibitors of branched chain amino acid synthesis (B), photosynthesis inhibitors at PS II $\left(\mathrm{C}_{1}\right)$ and mitosis inhibitors $\left(\mathrm{K}_{3}\right)$ was found for species richness in the field interior and community composition at the field margin. Interestingly, the herbicide use intensity index (HI) did not explain any significant fraction neither in the field interior nor at the field margin.

The importance of conversion tillage, crop rotation and land use history was less consistent across the response variables (Table $2.2 \& 2.3$ ). Crop rotation was found to influence weed cover and community composition, whereas it could not explain species richness. Community composition was related to the first three principal components of crop rotation, indicating that all included variables were potentially important. A net effect of crop rotation on community composition was detected at the field margin $(0.5 \%)$.

Among the environmental factors, the soil chemical variables were found to be potentially most important. Significant net effects of soil parameters were detected for species richness at the field margin (6.4\%) and for community composition both at the field margin (5.6\%) and in the field interior $(7.0 \%)$.

\subsubsection{Importance of the current crop and interactions with other management factors}

Margins of maize fields were with on average 11 weed species $100 \mathrm{~m}^{-2}$ less species-rich than margins of winter wheat fields with 15 species $100 \mathrm{~m}^{-2}$ (Fig. 2.5). For the field interior, where species richness was generally extremely low, the opposite picture was found. Winter-sown cereals were with 3 species $100 \mathrm{~m}^{-2}$ even species-poorer than maize fields with 6 species $100 \mathrm{~m}^{-2}$.

The current crop potentially explained a substantial amount of the variation in weed cover, species richness and community composition (Table 2.4). The crop effects were, however, restricted to the field interior and were interrelated with sowing date, fertilisation, herbicide use and crop rotation. Maize fields received about 2-5 times more organic fertilisers (on average $23.6 \mathrm{Mg} \mathrm{ha}^{-1} \mathrm{yr}^{-1}$, including animal manures and digested residues from biogas plants) than winter cereal fields. As a consequence, the added doses of $\mathrm{P}, \mathrm{K}, \mathrm{Ca}$ and $\mathrm{Mg}$ were 2-6 times higher in maize fields (Table 2.5). $\mathrm{N}$ input was not higher on maize fields as compared to winter cereal fields, as higher $\mathrm{N}$-inputs from organic fertilisers were balanced with lower mineral $\mathrm{N}$ fertilisation. Herbicide use intensity was found to be higher in maize and winter-sown wheat than in winter-sown barley (Table 2.5). The types of herbicides applied also differed substantially between crops. 

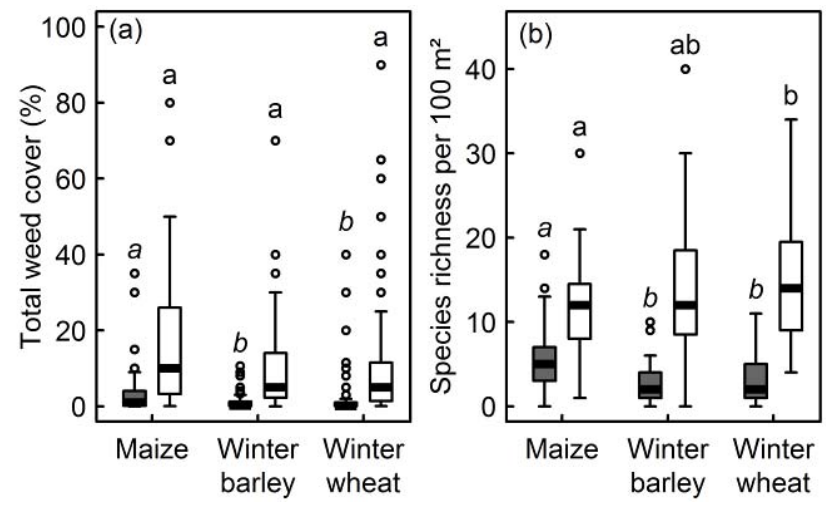

Fig. 2.5 Differences in (a) total weed cover (in \%) and (b) species richness per sampling plot between fields cultivated with maize $(n=71)$, winter barley $(n=64)$ and winter wheat $(\mathrm{n}=71)$. Plots from the field interior (grey bars, italic letters) and from the field margin (white bars, regular letters) were analysed separately. Different letters indicate significant differences between crops at $p \leq 0.05$.

No net effect of the crop was detectable after controlling for the effects of the other management factors. The sowing date and the crop were so tightly correlated, that neither factor explained any significant part of the variation when the other was controlled for, although taken individually both showed high explanatory power. The complementarity of the effects of the crop with fertilisation, herbicides and crop rotation was less strong. Although controlling for crop usually reduced the amount of variation explained by these factors, the remaining fractions were in many cases still significant (for details see Table 2.4). Likewise, the crop usually still explained significant parts of the variation when corrected for the effects of fertilisation, herbicides or crop rotation.

\subsection{Discussion}

\subsubsection{General importance of management factors for arable plant diversity}

The total amount of variation explained by the complete reduced models was high in our study as compared to previous studies with similar goals (Fried et al., 2008; Pinke et al., 2012). For community composition, we found the complete set of variables to explain $42 \%\left(\mathrm{R}^{2}\right)$ in the field interior (20 variables, $\mathbf{R}_{\text {adj }}=14 \%$ ) and $36 \%$ at the field margin (26 variables, $\left.\mathbf{R}^{2}{ }_{\text {adj }}=13 \%\right)$ including management, environmental and spatial predictors. Pinke et al. (2012) were able to explain $25 \%\left(\mathrm{R}^{2}\right)$ of the variation in community composition of 243 arable fields in Hungary with 24 variables describing the field management, environmental factors and the site context. Fried et al. (2008) explained 35\% (proportion of total inertia from CCA) of the variation in community composition from 694 fields throughout France with 14 management and environmental variables. The amount of explained variation was similarly high for weed cover (field interior: $\mathrm{R}^{2}=43 \% /$ margin: $\mathrm{R}^{2}=40 \%$ ) and species richness $(40 \%$ / 32\%). We are not aware of other similarly comprehensive investigations 
for these two response variables in conventionally managed farmland. The complex interactions of different predictors in agroecosystems and the noise which is necessarily generated in the data collection process define the limits of current statistical approaches for this type of assessments.

Our results confirm the general importance of field management factors for arable plant diversity, reaffirming that human influence strongly shapes arable plant assemblages. We found weed cover, species richness and community composition to respond to different sets of predictors, confirming previous results by Fried et al. (2008). Management factors were able to explain large proportions of the variations in weed cover and species richness in the field interior, whereas environmental factors did not contribute significantly. In contrast and in accordance with Pinke et al. (2012), our data show management factors to be less important than environmental factors for explaining community composition. This confirms our hypothesis that environmental factors acting as barriers to the dispersal and establishment of new species remain important for shaping community composition even in landscapes highly influenced by human management.

Table 2.4 Gross and net effects $\left(\mathrm{R}^{2}\right.$ adjusted $)$ of management factors found to be interacting with the cultivated crop. Net all gives the net effect after controlling for all other management factors, net $_{\text {crop }}$ gives the effect after controlling for the effects of crop, and crop $_{\text {var }}$ gives the net effect of crop after controlling for the respective variable. Note that only the significant variables from the final models (Table 2.2) have entered the analyses presented here. The number and kind of variables included in each set may differ between response variables. Please refer to table 2.2 for interpretation. For further details on the calculation see Methods section; ns $p>0.05$; $* p \leq 0.05 ; * * p \leq 0.01 ; * * * \leq 0.001$.

\begin{tabular}{|c|c|c|c|c|c|c|c|c|}
\hline \multirow{2}{*}{ Weed cover } & \multicolumn{2}{|c|}{ Field interior } & \multicolumn{6}{|c|}{ Field margin } \\
\hline & gross & net $_{\text {all }}$ & net $_{\text {crop }}$ & crop $_{\text {var }}$ & gross & net $_{\text {all }}$ & net $t_{\text {crop }}$ & crop $_{\text {var }}$ \\
\hline Crop & $8.8^{* *}$ & 0 & & & 0 & - & & \\
\hline Sowing date & $9.7^{* * *}$ & 0 & 0 & 0 & 0 & - & - & - \\
\hline Fertilisation & $12.9^{* *}$ & $8.0^{* *}$ & $5.1^{* *}$ & 0 & $2.5^{* *}$ & $2.5^{* *}$ & $1.8^{*}$ & - \\
\hline Herbicides & $5.9^{* * *}$ & 0 & 0 & $3.5^{*}$ & 0 & - & - & - \\
\hline Crop rotation & $3.3^{* *}$ & 0 & 0 & $6.1^{* *}$ & 0 & - & - & - \\
\hline Total explained var. & $17.4^{* *}$ & & & & $2.5^{* *}$ & & & \\
\hline \multicolumn{9}{|l|}{ Species richness } \\
\hline Crop & $9.5^{* *}$ & 0 & & & $3.9^{* * *}$ & 0 & & \\
\hline Sowing date & $10.0^{* *}$ & 0 & 0 & 0 & $3.1^{* * *}$ & 0 & & \\
\hline Fertilisation & $9.2^{* *}$ & 0 & 0 & $1.8^{*}$ & $4.4^{* *}$ & $4.5^{* *}$ & $5.0^{* *}$ & $4.5^{* * *}$ \\
\hline Herbicides & $4.9^{* *}$ & $2.1^{*}$ & $2.6^{* *}$ & $7.2^{* *}$ & 0 & - & - & - \\
\hline Crop rotation & 0 & - & - & - & 0 & - & - & - \\
\hline Total explained var. & $13.1^{* *}$ & & & & $10.8^{* * *}$ & & & \\
\hline \multicolumn{9}{|c|}{ Community composition } \\
\hline Crop & $0.6^{* *}$ & 0 & & & $0.9^{* * *}$ & 0 & & \\
\hline Sowing date & $0.7^{* *}$ & 0 & 0 & 0 & $0.8^{* *}$ & 0 & 0 & $0.1^{*}$ \\
\hline Fertilisation & $0.7^{\text {** }}$ & 0 & 0 & $0.2^{*}$ & $0.5^{* *}$ & 0 & & $0.4^{* * *}$ \\
\hline Herbicides & $0.8^{* *}$ & 0 & $0.2^{*}$ & $0.2^{*}$ & $0.7^{* *}$ & $0.2^{*}$ & $0.3^{* *}$ & $0.5^{* * *}$ \\
\hline Crop rotation & $1.4^{* *}$ & $1.2^{* * *}$ & $1.2^{* *}$ & $0.4^{* * * *}$ & $1.1^{* *}$ & $0.6^{*}$ & $0.7^{* * *}$ & $0.6^{* * *}$ \\
\hline Total explained var. & $2.4^{* * * *}$ & & & & $1.9^{* * * *}$ & & & \\
\hline
\end{tabular}


Table 2.5 Differences in macro- and micro-environmental factors, soil chemistry and field management practices (fertilisation, herbicide use and crop rotation) between stands of conventionally managed maize, winter-sown wheat and winter-sown barley. Means and standard deviation $( \pm$ SE) are presented. Different letters indicate significant differences between groups (separate analyses for the field interior and the field margin, non-parametric Behrens-Fisher-test for multiple comparisons, $P \leq 0.05$ ). No differences in fertiliser input or herbicide applications between the three crops were found for the year preceding the study. Results are therefore not shown here. HRAC $=$ Herbicide classification system from the Herbicide Resistance Action Committee. Syr $=$ year of survey, pyr = preceding year.

\begin{tabular}{|c|c|c|c|c|c|c|}
\hline & \multicolumn{3}{|c|}{ Field interior } & \multicolumn{3}{|c|}{$\begin{array}{c}\text { Field margin } \\
\text { (only if different from interior) }\end{array}$} \\
\hline & Maize & Wheat & Barley & Maize & Wheat & Barley \\
\hline Sample size & 71 & 71 & 64 & 71 & 71 & 64 \\
\hline Sowing date (days) & $22 \mathrm{Apr} \pm 4$ & 7 Oct \pm 10 & $22 \mathrm{Sep} \pm 5$ & $22 \mathrm{Apr} \pm 4$ & 7 Oct \pm 10 & $22 \mathrm{Sep} \pm 5$ \\
\hline \multicolumn{7}{|l|}{ Macro environment } \\
\hline Elevation (m a. s. 1.) & $215 \pm 5^{\mathrm{a}}$ & $234 \pm 7^{\mathrm{a}}$ & $222 \pm 6^{\mathrm{a}}$ & & & \\
\hline Precipitation (Mar.-Sept.) & $386 \pm 4^{\mathrm{a}}$ & $394 \pm 5^{\mathrm{a}}$ & $383 \pm 5^{\mathrm{a}}$ & & & \\
\hline Temperature (Mar.-Sept.) & $12.6 \pm 0.1^{\mathrm{a}}$ & $12.4 \pm 0.1^{\mathrm{a}}$ & $12.6 \pm 0.1^{\mathrm{a}}$ & & & \\
\hline Sunshine hours (Mar.-Sept.) & $1160 \pm 2^{\mathrm{a}}$ & $1156 \pm 2^{\mathrm{a}}$ & $1160 \pm 2^{\mathrm{a}}$ & & & \\
\hline \multicolumn{7}{|l|}{ Micro environment (field interior) } \\
\hline Slope $\left(^{\circ}\right)$ & $1.1 \pm 0.1^{\mathrm{a}}$ & $1.8 \pm 0.2^{b}$ & $1.8 \pm 0.2^{b}$ & $1.2 \pm 0.2^{\mathrm{a}}$ & $1.7 \pm 0.2^{\mathrm{a}}$ & $1.8 \pm 0.2^{\mathrm{a}}$ \\
\hline Crop cover $(\%)$ & $66.2 \pm 2.4^{\mathrm{a}}$ & $57.7 \pm 1.5^{\mathrm{b}}$ & $66.0 \pm 1.6^{a}$ & $49.0 \pm 2.0^{\mathrm{a}}$ & $39.7 \pm 1.4^{\mathrm{b}}$ & $46.1 \pm 1.7^{\mathrm{a}}$ \\
\hline Tree/shrub cover $(\%)$ & 0 & 0 & 0 & $0.9 \pm 0.3^{\mathrm{a}}$ & $2.5 \pm 1.2^{\mathrm{a}}$ & $1.1 \pm 0.3^{\mathrm{a}}$ \\
\hline \multicolumn{7}{|l|}{ Soil chemistry (field interior) } \\
\hline $\mathrm{pH}$ & $7.1 \pm 0.1^{\mathrm{a}}$ & $7.0 \pm 0.1^{\mathrm{a}}$ & $7.1 \pm 0.1^{\mathrm{a}}$ & $7.2 \pm 0.1^{\mathrm{a}}$ & $7.2 \pm 0.1^{\mathrm{a}}$ & $7.2 \pm 0.1^{\mathrm{a}}$ \\
\hline Base saturation (\%) & $99.9 \pm 0.1^{\mathrm{a}}$ & $99.5 \pm 0.2^{\mathrm{a}}$ & $99.7 \pm 0.1^{\mathrm{a}}$ & $99.8 \pm 0.1^{\mathrm{a}}$ & $99.6 \pm 0.2^{\mathrm{a}}$ & $99.8 \pm 0.1^{\mathrm{a}}$ \\
\hline $\mathrm{C} / \mathrm{N}$-ratio & $9.2 \pm 0.1^{\mathrm{a}}$ & $9.4 \pm 0.2^{\mathrm{ab}}$ & $9.6 \pm 0.1^{b}$ & $9.3 \pm 0.1^{\mathrm{a}}$ & $9.7 \pm 0.2^{\mathrm{a}}$ & $9.7 \pm 0.2^{\mathrm{a}}$ \\
\hline $\operatorname{SOM}(\%)$ & $3.6 \pm 0.1^{\mathrm{a}}$ & $3.5 \pm 0.1^{\mathrm{a}}$ & $3.8 \pm 0.1^{\mathrm{a}}$ & $3.6 \pm 0.1^{\mathrm{a}}$ & $3.6 \pm 0.1^{\mathrm{a}}$ & $3.8 \pm 0.1^{\mathrm{a}}$ \\
\hline Plant-available $\mathrm{P}\left(\mu \mathrm{mol} \mathrm{P} * \mathrm{~g}_{(\mathrm{dry} \text { weight })}{ }^{-1}\right)$ & $2.8 \pm 0.2^{\mathrm{a}}$ & $2.3 \pm 0.1^{\mathrm{a}}$ & $2.0 \pm 0.1^{\mathrm{a}}$ & $2.7 \pm 0.2^{\mathrm{a}}$ & $2.2 \pm 0.1^{\mathrm{ab}}$ & $1.9 \pm 0.2^{\mathrm{b}}$ \\
\hline \multicolumn{7}{|l|}{ Fertilisation (year of survey) } \\
\hline $\mathrm{N}$-fertilisation (kg/ha) & $183 \pm 6^{\text {ab }}$ & $206 \pm 5^{a}$ & $170 \pm 5^{\mathrm{b}}$ & & & \\
\hline P-fertilisation (kg/ha) & $96 \pm 5^{\mathrm{a}}$ & $30 \pm 4^{b}$ & $22 \pm 3^{\mathrm{b}}$ & & & \\
\hline K-fertilisation $(\mathrm{kg} / \mathrm{ha})$ & $117 \pm 8^{\mathrm{a}}$ & $57 \pm 8^{b}$ & $26 \pm 4^{\mathrm{c}}$ & & & \\
\hline S-fertilisation (kg/ha) & $12 \pm 1^{\mathrm{a}}$ & $26 \pm 2^{b}$ & $25 \pm 2^{b}$ & & & \\
\hline Ca-fertilisation $(\mathrm{kg} / \mathrm{ha})$ & $221 \pm 60^{\mathrm{a}}$ & $38 \pm 14^{\mathrm{b}}$ & $36 \pm 13^{\mathrm{b}}$ & & & \\
\hline Mg-fertilisation (kg/ha) & $36 \pm 5^{a}$ & $18 \pm 2^{\mathrm{b}}$ & $12 \pm 1^{\mathrm{c}}$ & & & \\
\hline Organic fertilisers $(1000 \mathrm{~kg} / \mathrm{ha})$ & $23.6 \pm 1.9^{a}$ & $10.0 \pm 1.3^{\mathrm{b}}$ & $4.2 \pm 0.8^{\mathrm{c}}$ & & & \\
\hline
\end{tabular}


Table 2.5 (continued)

\begin{tabular}{|c|c|c|c|c|c|c|}
\hline & \multicolumn{3}{|c|}{ Field interior } & \multirow{2}{*}{\multicolumn{3}{|c|}{$\begin{array}{c}\text { Field margin } \\
\text { (only if different from interior) }\end{array}$}} \\
\hline & & & & & & \\
\hline & Maize & Wheat & Barley & Maize & Wheat & Barley \\
\hline \multicolumn{7}{|l|}{ Herbicide use } \\
\hline Herbicide use intensity index (syr) & $1.7 \pm 0.1^{\mathrm{a}}$ & $1.9 \pm 0.1^{\mathrm{a}}$ & $1.4 \pm 0.1^{\mathrm{b}}$ & & & \\
\hline \# of mechanisms of action (syr) & $3.5 \pm 0.1^{\mathrm{a}}$ & $3.0 \pm 0.1^{\mathrm{B}}$ & $3.1 \pm 0.1^{\mathrm{ab}}$ & & & \\
\hline A (ACCase inhibitors, $\mathrm{kmol} / \mathrm{ha}$ ) & $3.2 \pm 0.8^{\mathrm{a}}$ & $10.7 \pm 1.8^{b}$ & $12.5 \pm 1.9^{b}$ & & & \\
\hline B (ALS/AHAS inhib., kmol/ha) & $23.3 \pm 1.2^{\mathrm{a}}$ & $16.1 \pm 1.2^{\mathrm{b}}$ & $10.4 \pm 1.4^{\mathrm{c}}$ & & & \\
\hline $\mathrm{C}_{1}$ (PS-II inhib., kmol/ha) & $107.8 \pm 4.0^{\mathrm{a}}$ & $34.1 \pm 4.4^{\mathrm{b}}$ & $8.0 \pm 2.3^{\mathrm{c}}$ & & & \\
\hline $\mathrm{C}_{2}$ (PS-II inhib., kmol/ha) & $12.9 \pm 4.4^{\mathrm{a}}$ & $37.5 \pm 9.7^{\mathrm{ab}}$ & $57.0 \pm 9.5^{b}$ & & & \\
\hline $\mathrm{C}_{3}$ (PS-II inhib., kmol/ha) & $34.8 \pm 3.6^{\mathrm{a}}$ & $10.3 \pm 2.5^{\mathrm{b}}$ & $10.1 \pm 2.7^{\mathrm{b}}$ & & & \\
\hline E (Protoporphyrinogen oxidase inhib., kmol/ha) & $0.9 \pm 0.2^{\mathrm{a}}$ & $2.0 \pm 0.4^{\mathrm{a}}$ & $7.6 \pm 2.6^{\mathrm{a}}$ & & & \\
\hline $\mathrm{F}_{1}$ (Carotenoid biosynthesis inhib., kmol/ha) & $7.7 \pm 1.9^{\mathrm{a}}$ & $14.4 \pm 2.2^{\mathrm{b}}$ & $31.3 \pm 3.1^{\mathrm{c}}$ & & & \\
\hline $\mathrm{F}_{2}$ (Carotenoid biosynthesis inhib., kmol/ha) & $12.9 \pm 1.5^{\mathrm{a}}$ & $5.3 \pm 1.1^{\mathrm{b}}$ & $0.5 \pm 0.3^{\mathrm{c}}$ & & & \\
\hline $\mathrm{F}_{3}$ (Carotenoid biosynthesis inhib., kmol/ha) & $1.6 \pm 0.5^{\mathrm{a}}$ & $8.9 \pm 7.1^{b}$ & $0.2 \pm 0.1^{b}$ & & & \\
\hline $\mathrm{F}_{4}$ (Carotenoid biosynthesis inhib., $\mathrm{kmol} / \mathrm{ha}$ ) & $0.0 \pm 0.0^{\mathrm{a}}$ & $0.3 \pm 0.2^{\mathrm{a}}$ & $0.8 \pm 0.4^{\mathrm{a}}$ & & & \\
\hline G (EPSP synthase inhib. =glyphosate, $\mathrm{kmol} / \mathrm{ha}$ ) & $106.7 \pm 13.1^{\mathrm{a}}$ & $89.5 \pm 11.2^{\mathrm{a}}$ & $74.2 \pm 10.0^{\mathrm{a}}$ & & & \\
\hline $\mathrm{K}_{1}$ (Inhib. of microtubule assembly, $\mathrm{kmol} / \mathrm{ha}$ ) & $11.9 \pm 5.4^{\mathrm{a}}$ & $25.5 \pm 8.6^{\mathrm{a}}$ & $35.2 \pm 8.8^{\mathrm{A}}$ & & & \\
\hline $\mathrm{K}_{3}$ (Mitosis inhib. kmol/ha) & $75.8 \pm 10.6^{a b}$ & $43.9 \pm 7.0^{\mathrm{a}}$ & $64.4 \pm 7.6^{b}$ & & & \\
\hline $\mathrm{N}$ (Inhib. of lipid synthesis, kmol/ha) & $9.9 \pm 5.6^{\mathrm{a}}$ & $41.9 \pm 12.7^{\mathrm{a}}$ & $15.7 \pm 8.5^{\mathrm{a}}$ & & & \\
\hline $\mathrm{O}$ (Synthetic auxins, kmol/ha) & $26.0 \pm 4.4^{\mathrm{a}}$ & $71.5 \pm 7.6^{b}$ & $54.9 \pm 6.7^{b}$ & & & \\
\hline \multicolumn{7}{|l|}{ Crop rotation (last 10 yrs. before study) } \\
\hline \# of crops & $4.1 \pm 0.1^{\mathrm{a}}$ & $4.0 \pm 0.1^{\mathrm{a}}$ & $4.3 \pm 0.1^{\mathrm{a}}$ & & & \\
\hline Prop. of maize (\%) & $27 \pm 2^{\mathrm{a}}$ & $10 \pm 1^{\mathrm{b}}$ & $9 \pm 1^{\mathrm{b}}$ & & & \\
\hline Prop. of winter wheat (\%) & $37 \pm 1^{\mathrm{a}}$ & $51 \pm 1^{b}$ & $37 \pm 1^{\mathrm{a}}$ & & & \\
\hline Prop. of winter-sown crop (\%) & $58 \pm 2^{\mathrm{a}}$ & $76 \pm 2^{b}$ & $77 \pm 2^{b}$ & & & \\
\hline Prop. of legumes (\%) & $2 \pm 1^{\mathrm{a}}$ & $3 \pm 1^{\mathrm{a}}$ & $2 \pm 1^{\mathrm{a}}$ & & & \\
\hline Prop. of fallow period/grassland (\%) & $3 \pm 1^{\mathrm{a}}$ & $0 \pm 0^{\mathrm{a}}$ & $1 \pm 1^{\mathrm{a}}$ & & & \\
\hline Prop. of biennial/perennial crops (\%) & $4 \pm 1^{\mathrm{a}}$ & $0 \pm 0^{\mathrm{a}}$ & $3 \pm 1^{\mathrm{a}}$ & & & \\
\hline
\end{tabular}


With on average 3-6 species $100 \mathrm{~m}^{-2}$, the interior of conventionally managed maize and winter cereal fields was found to be extremely species-poor. This is in accordance with Meyer et al. (2013) who found a median of six species per plot on loamy soils in Germany. More than half of the recorded arable plants in the field interior belonged to one of only nine very common weedy species (Fallopia convolvulus, Galium aparine, Polygonum aviculare, Chenopodium album, Viola arvensis, Convolvolus arvensis, Alopecurus myosuroides, Cirsium arvense and Bromus sterilis, in decreasing order of importance). On extensively managed, low-input arable land, much higher species richness and abundances have been recorded in previous studies (e.g. 21-35 species $100 \mathrm{~m}^{-2}$, Albrecht et al., 2009; Seifert et al., 2014; cp. also Kleijn and van der Voort, 1997; Walker et al. 2007). This extremely low diversity combined with very low arable plant cover $(67 \%$ of all fields had a cover value $\leq 1 \%)$ indicates that modern high-input cropland must represent an extremely impoverished habitat for insects, birds and mammals. Most species, including many pest predators, depend upon more heterogeneous habitats in terms of floristic diversity.

As expected, the explanatory power of field management factors was higher in the field interior than at the field margins. Field margins tend to receive less fertiliser and herbicides (Wilson and Aebischer, 1995) and crop yields are usually lower (Sparkes et al., 1998). Being ecotones, field margins are also influenced by a wider range of factors than the interior of arable fields, including inputs from the adjacent habitats (Marshall and Arnolds, 1995). These effects lead to strongly increased cover values and species numbers at the field margin (Fig. 2.5). Correspondingly, we found the influence of environmental factors on arable plant diversity to be higher at the field margin than in the field interior, possibly due to the release of the arable plant assemblages from chemical stressors and competition with the crop (Pinke et al., 2012).

In this study, we tested for the effects of fertiliser and herbicide applications on arable plant diversity at the field margins, assuming a linear relationship with the application rates in the field interior. This was a necessary simplification. More exactly, the difference in management intensity between the margin and the interior is expected to vary depending on the site conditions, the machinery used, and the weather conditions on the day of application and ultimately even on the farmer's mood and preferences (Wilson and Aebischer, 1995). As a result, the reduced explanatory power at the field margin might partly be due to less accurate data on fertiliser and herbicide input.

\subsubsection{Effects of particular management factors on arable plant diversity and interactions with environmental and spatial factors}

The current crop, fertilisation and to a lesser extent also herbicide use as well as soil characteristics were found to be the most important predictors of arable plant diversity in Central European high-input croplands, apart from spatial factors (Fried et al, 2008; Lososová et al., 2004; 
Pinke et al., 2012). Due to many inter-relations between field management factors, it seems impossible to single out any particular factor as most important for reducing or enhancing arable plant diversity.

Fertilisation was found to be a promising target as it was shown to be related to all three response variables. Contrary to results from previous studies (Pyšek and Lepš, 1991; Storkey et al., 2012), N fertilisation was not singled out as the most important explanatory factor. The data reveal that rates of $\mathrm{N}, \mathrm{P}, \mathrm{K}$ and $\mathrm{Mg}$ fertilisation were too highly correlated to allow for their statistical separation via the approach we applied and were therefore all subsumed in one principal component. Although we found significant gross effects of PC1 in the field interior, no net effects of this group of fertilisers persisted. This was due to the fact that the highest inputs of these nutrients resulted from organic fertilisers which contain all four elements and are applied at highest rates in maize fields and much more rarely in barley fields (Table 2.5). We could therefore not separate the effects of fertilisation from the overall crop effect. The effects of herbicide applications might also have overridden the fertilisation effect.

$\mathrm{S}$ fertilisation represented a second gradient (PC2) and was statistically independent from the other types of fertilisers. $\mathrm{S}$ fertilisers were applied mainly in the form of ammonium sulphate or ammonium nitrate sulphate. The fact that sulphur fertilisation during the year preceding the survey was positively correlated to species richness (Fig. 2.4a) and weed cover (Fig. 2.3) is interesting. As proposed by Smith et al. (2009), sulphur fertilisation potentially increases resource diversity in the soil and consequently reduces the competition between weeds and crops. Fields with $\mathrm{S}$ fertilisation might therefore support a higher weed cover without decreases in crop yields (Grant et al., 2007; Smith et al., 2009). The Resource Pool Diversity Hypothesis (Smith et al., 2009) was also supported by the fact that the negative relationship between crop cover and weed cover became significant only after partialling out the confounding effect of $\mathrm{S}$ fertilisation. The diversification of soil resource pools might therefore indeed represent an opportunity for enhancing arable plant diversity without compromising crop yields. These conclusions must remain highly tentative and need further experimental verification. In the light of extremely low weed cover values in the field interior, it seems, however, unlikely that the magnitude of such effects is large enough to positively influence species of higher trophic levels or to halt the on-going decline in arable plant diversity (Meyer et al., 2013; Storkey et al., 2012).

Contrary to our hypothesis the herbicide use intensity index (HI) was not found to explain any of the plant diversity metrics. Several aspects might contribute to this unexpected lack of fit: (1) The maximum admitted application rate, which is an important parameter for calculating $\mathrm{HI}$, is determined by governmental bodies based on maximum residue levels in the final products (EC, 1991-2013). It does not necessarily imply any comparability between herbicides in terms of effectiveness for eradicating weeds. The HI might thus not be a suitable proxy for ecological assessments of herbicide pressure on weed assemblages. (2) We would expect a certain threshold value above which any further 
increase in herbicide dosage will not lead to further decrease in weed diversity. This threshold might have been exceeded on the fields with extremely low weed cover, i.e. potentially on $2 / 3$ of all assessed fields. Our study highlights the importance of the development of a more appropriate herbicide intensity index for assessing herbicide impacts in agro-ecosystems. The strong inter-relationships we found between different sets of explanatory factors show that the development of such an index and the determination of any potential threshold value can only be realised based on experimental assessments and controlling for confounding factors. Such an index would be a useful tool for determining the external economic impacts, i.e. the "cost of biodiversity loss" (TEEB, 2010), of herbicide applications on a field by field basis.

We found the approach to use the number of molecules of the active ingredients of herbicides to be more promising. Structuring the herbicide dosage data by HRAC groups for investigating differences in the impacts of particular modes of action yielded interesting new insights. We found the amount of mitosis inhibitors $\left(\mathrm{K}_{3}\right)$ to exhibit significant net negative effects on species richness in the field interior after partialling out the effects of crop, sampling year and spatial autocorrelation (Fig. 2.4b). Common mitosis inhibitors applied on the surveyed fields were flufenacet and pethoxamid. We did not find similarly large effects for the other groups of herbicides. These differential effects between HRAC groups might be due to several reasons. (1) The degree of selectivity of target weeds and crops might vary between HRAC classes, e.g. the different sulfonylureas from group B are commonly targeted at a certain crop and certain weed species (Drobny et al, 2012), whereas the mitosis inhibitors from group $\mathrm{K}_{3}$ affect a broader set of species and crops (Böger, 2003; Busi, 2014). $\mathrm{K}_{3}$ herbicides are therefore more likelyto exhibit a dose-dependent "group effect" as postulated in our initial hypothesis. (2) The effect of herbicide groups which target mainly one of the three assessed crops, such as $\mathrm{C}_{1}$ herbicides which are only applied in maize (Table 2.5), can statistically not be separated from the overall effect of the crop. As $\mathrm{K}_{3}$ herbicides are applied across all three crops, they have higher potential to show significant net effects.

Among management factors crop rotation, conversion tillage with a mouldboard plough and land use history were found to be particularly important for explaining community composition. Our initial hypotheses were thus largely confirmed. This leads to the conclusion that dynamic mosaic landscapes including a wide range of different annual and perennial crops, fields with and without conversion tillage and a range of land uses other than crop production will in the long term secure highest levels of arable plant diversity (see also Gabriel et al. 2006). Contrary to our initial hypothesis and to data from literature (Ball, 1992; Teasdale et al., 1991), mouldboard ploughing was not found to decrease weed cover. The effect might have been overridden by the stronger effects of herbicides and fertilisation. 
The fact that soil parameters were found to play a prominent role in explaining community composition highlights the importance to maintain landscapes with diverse soil conditions. In the light of increasing homogenisation of habitat conditions on arable land through eutrophication and increasingly larger agricultural units (Smart et al., 2006), it is vital to conserve mesophilous and nutrient-poor habitats for maintaining biodiversity (Storkey et al., 2012).

\subsubsection{Importance of the current crop and interactions with other management factors}

Our results confirm that the current crop is a sound proxy of management techniques. In particular, it is the only easily derived predictor which subsumes aspects of crop phenology and timing of management practices. More detailed data on fertilisation, herbicide applications and crop rotation will, however, add valuable additional information and should wherever possible be incorporated.

The analysis of the interrelationship between crop type and management factors confirmed that the management of the winter-sown cereals wheat and barley diverged in many aspects from the summersown crop maize. Overall $\mathrm{N}$ fertilisation was not found to differ between crops, but maize fields received the highest doses of organic fertiliser leading to extremely high P inputs. Doses of $>100 \mathrm{~kg}$ $\mathrm{P}_{2} \mathrm{O}_{5} \mathrm{ha}^{-1} \mathrm{yr}^{-1}$, as recorded for almost $50 \%$ of the maize fields, are likely to exceed the nutrient removal with maize harvest (LWK NRW, 2012) and can lead to substantial P leaching to the groundwater, particularly in maize-dominated crop rotations. Herbicide applications in maize fields differ compared to winter cereal fields in timing of applications and types of the herbicides. Systematic differences in overall quantity of herbicide use were not identified and the herbicide use intensity index was equally high in maize fields and in winter wheat fields. The HI values in the study region were found to be comparable to values found by comprehensive assessments across Germany (Roßberg, 2011). Differences in timing of herbicide treatments are difficult to capture and were represented in this study by the variable "current crop" and "sowing date". Both variables were found to be highly significant. Due to the strong correlation between both, it was, however, not possible to distinguish between the effects of timing, type and size of the differences in management practices represented by these two variables. New approaches for more adequately incorporating temporal aspects of field management in scientific impact assessments can potentially help to increase the explanatory power of the respective models.

\subsection{Conclusions}

The maintenance of tolerable levels of arable plants in conventional crop systems is a key requirement to allow for the protection of a basic level of biodiversity in agricultural landscapes, including pollinators and pest-predators. We found some indication that further research with regard to 
the Resource Pool Diversity Hypothesis (Smith et al., 2009) and more particularly concerning S fertilisation might yield opportunities for increasing arable plant diversity without compromising yields. The expected magnitude of the benefits of this approach is, however, unlikely to be large enough to halt the on-going decline in farmland biodiversity. The results we present in this study show clearly that the necessary increase in arable plant diversity to restore functional farmland food webs cannot be achieved by simply altering certain management factors, such as fertilisation or herbicide use, within the range of current conventional farming practices. Well researched approaches such as sparing field margins from fertilisation and herbicide treatments (Kleijn and van der Voort, 1997; Walker et al. 2007) should be favoured as viable options as they balance biodiversity benefits and production goals. In line with Garnett et al. (2013) it seems necessary to rethink the current farming approaches more radically; inventing new technologies and adapting farming practices to specific regional requirements should be options. In the meanwhile, it is urgently needed to conserve appropriate habitats as sanctuaries for the arable flora in regions such as Germany, where this group of species is suffering from rapid decline (Meyer et al., 2013; Storkey et al., 2012). In Germany, this type of high-nature-value farmland has dropped to extremely low levels due to financial unattractiveness of the respective agri-environmental schemes in the face of strong support for energy crop production and high commodity prices for agricultural products. The fact that extensively managed arable land will also not be eligible as 'ecological focus area' in Germany under the new EU common agricultural policy highlights the necessity to improve the financial support of the pertinent schemes in the framework of the EU rural development programmes.

\subsection{Acknowledgements}

This study was funded by the German Federal Ministry of Education and Research (BMBF) and is part of the BEST Research Framework at the University of Göttingen (http://www.bestforschung.de). The authors express their sincere thanks to the 60 farmers who contributed to this research by permitting access to their fields and by filling the questionnaires on field management. 


\subsection{References}

Albrecht, H.; Mayer, F.; Wiesinger, K. (2009) Biodiversität und Artenschutz bei Ackerwildpflanzen. Laufener Spezialbeiträge 2/09. 135-142.

Altieri, M. A. (1999) The ecological role of biodiversity in agroecosystems. Agriculture, Ecosystems and Environment, 74, 19-31.

Andreasen, C., Scovgaard, I. M. (2009) Crop and soil factors of importance for the distribution of plant species on arable fields in Denmark. Agriculture, Ecosystems and Environment, 133, 61-67.

Ball, D.A. (1992) Weed seedbank response to tillage, herbicides and crop rotation sequence. Weed Science, 40, 654-659.

Bergelson, J., Newman, J. A., Floresroux, E. M. (1993) Rates of weed spread in spatially heterogeneous environments. Ecology, 74, 999-1011.

BKG (2005) Digitales Geländemodell für Deutschland - DGM-D (ed Bundesamt für Kartographie und Geodäsie), Frankfurt a. M., Germany.

Boess, J., Gehrt, E., Müller, U., Ostmann, U., Sbresny, J., Steininger, A. (eds) (2004) Erläuterungen zur digitalen nutzungsdifferenzierten Bodenkundlichen Übersichtskarte 1:50.000 (BÜK50n) von Niedersachsen, NLfB, Arbeitshefte Boden, 3.

Böger, P. (2003) Mode of action for cloroacetamides and functionally related compounds. Journal of Pesticide Science, 28, 324-329.

Borcard, D., Legendre, P. (2002) All-scale spatial analysis of ecological data by means of principal coordinates of neighbour matrices. Ecological Modelling, 153, 51-68.

Busi, R. (2014) Resistance to herbicides inhibiting the biosynthesis of very-long-chain fatty acids. Pest Management Science, 70, 1378-1384.

Cimalová, S., Lososová, Z. (2009) Arable weed vegetation of the northeastern part of the Czech Republic: effects of environmental factors on species composition. Plant Ecology, 203, 45-57.

Cousens, R. (1985) A simple model relating yield loss to weed density. Annals of Applied Biology, 107, 239-252.

Délye, C. (2005) Weed resistance to acetyl coenzyme A carboxylase inhibitors: an update. Weed Science, 53, 728-746.

Drobny, H. G., Schulte, M., Strek, H. J. (2012) 25 Jahre Sulfonylharnstoff-Herbizide - ein paar Gramm veränderten die Welt der chemischen Unkrautbekämpfung. 25th German Conference on Weed Biology and Weed Control, March 13-15, 2012, Braunschweig, Germany. Julius-KühnArchiv, 434, 21-33.

DWD, 2013. Klimadaten - Mittelwerte 30-jähriger Perioden, Deutscher Wetterdienst. http://www.dwd.de, last accessed 25/06/2013.

EC - European Commission, 1991-2013. Guidelines for residue data under Directive 91/414/EEC and Regulation EC 396/2005. http://ec.europa.eu/food/plant/pesticides/max_residue_levels/ guidelines/index_en.htm, last accessed 28/06/2015..

Evans, D. M., Pocock, M. J. O., Brooks, J., Memmott, J. (2011) Seeds in farmland food-webs: Resource importance, distribution and the impacts of farm management. Biological Conservation, 144, 2941-2950.

Fried, G., Norton, L. R., Reboud, X. (2008) Environmental and management factors determining weed species composition and diversity in France. Agriculture, Ecosystems and Environment, 128, 68-76.

Fried, G., Petit, S., Dessaint, F., Reboud, X. (2009) Arable weed decline in Northern France: Crop edges as refugia for weed conservation? Biological Conservation, 142, 238-243.

Gabriel, D., Roschewitz, I., Tscharntke, T.,Thies, C. (2006) Beta diversity at different spatial scales: plant communities in organic and conventional agriculture. Ecological Applications, 26, 20112021.

Gabriel, D., Tscharntke, T. (2007) Insect pollinated plants benefit from organic farming. Agriculture, Ecosystems and Environment, 118, 43-48. 
Garnett, T., Appleby, M. C., Balmford, A., Bateman, I. J., Benton, T. G., Bloomer, P. et al. (2013) Sustainable intensification in agriculture: premises and policies. Science Magazine, 341, 33-34.

Grant, C. A., Derksen, D. A., Blackshaw, R. E., Entz, T., Janzen, H. H. (2007) Differential response of weed and crop species to potassium and sulphur fertilizers. Canadian Journal of Plant Sciences, 87, 293-296.

Helms, J., Munzel, U. (2009) The npmc package - Nonparametric multiple comparisons. Version 1.07. ftp://ftp.ccu.edu.tw/pub/languages/CRAN/web/packages/npmc/npmc.pdf, last accessed $08 / 10 / 2013$

HFA (2005) Eine Loseblatt-Sammlung der Analysemethoden im Forstbereich (ed Gutachterausschuss Forstliche Analytik), Handbuch Forstliche Analytik - Grundwerk.

Hole, D. G., Perkins, A. J., Wilson, J. D., Alexander, I. H., Grice, P. V., Evans, A. D. (2005) Does organic farming benefit biodiversity? Biological Conservation, 122, 113-130.

Kleijn, D., Kohler, F., Báldi, A., Batáry, P., Concepción, E. D., Clough, Y. et al. (2009) On the relationship between farmland biodiversity and land-use intensity in Europe. Proceedings of the Royal Society B: Biological Sciences, 276, 903-909.

Kleijn, D., van der Voort, L. A. C. (1997) Conservation headlands for rare arable weeds: the effects of fertilizer application and light penetration on plant growth. Biological Conservation, 81, 57-67.

LBEG (ed) (2010) Geologische Karte von Niedersachsen 1:50 000 - Grundkarte (GK50), Niedersächsisches Landesamt für Bergbau, Energie und Geologie. http://www.lbeg.niedersachsen.de/portal/live.php?navigation_id=732\&article_id=594\&_psmand= 4 , last accessed 21/05/2014.

Legendre, P. (2008) Studying beta diversity: ecological variation partitioning by multiple regression and canonical analysis. Journal of Plant Ecology, 1, 3-8.

Legendre, P., Gallagher, E. D. (2001) Ecologically meaningful transformations for ordination of species data. Oecologia, 129, 271-280.

Lososová, Z., Chytrý, M., Cimalová, S., Kropáč, Z., Otýpková, Z. (2004) Weed vegetation of arable land in Central Europe: gradients of diversity and species composition. Journal of Vegetation Science, 15, 415-422.

LWA Leinefelde-Worbis (2011) Anbaufläche je Kultur 2000-2010, Landwirtschaftsamt LeinefeldeWorbis.

LWA Sömmerda (2011) Landwirtschaftliche Fläche nach Kulturen 2005-2010, Landwirtschaftsamt Sömmerda.

LWK Niedersachsen (2010) Bestellte Fläche je Feldfrucht und Gemeinde im Landkreis Göttingen 2010, Landwirtschaftskammer Niedersachsen.

LWK NRW (2012) Ratgeber - Düngung mit Phosphat, Kali, Magnesium (ed Landwirtschaftskammer Nordrhein-Westfalen). $\quad$ http://www.landwirtschaftskammer.de/landwirtschaft/ackerbau/pdf/ phosphat-kalium-magnesium-pdf.pdf, last accessed 06/06/2014.

Marshall, E. J. P, Arnold, G. M. (1995) Factors affecting field weed and field margin flora on a farm in Essex, UK. Landscape and Urban Planning, 31, 205-216

Marshall, E. J. P., Brown, V. K., Boatman, N. D., Lutman, P. J., Squire, G. R., Ward, L. K. (2003) The role of weeds in supporting biological diversity within crop fields. Weed Research, 43, 77-89.

Menne, H., Köcher, H. (2012) HRAC classification of herbicides and resistance development, in Modern crop protection compounds (eds W. Kramer und U. Schirmer), Wiley-VCH Publishing, Weinheim, Germany, 5-26.

Meyer, S., Wesche, K., Krause, B., Leuschner, C. (2013) Dramatic losses of specialist arable plants in Central Germany since the 1950s/60s - a cross-regional analysis. Diversity and Distributions, 19, 1175-1187.

Meynen, E., Schmithüsen, J. (1953-1962) Handbuch der naturräumlichen Gliederung Deutschlands, Selbstverlag der Bundesanstalt für Landeskunde, Remagen, Germany. 
Nagai, T., Taya, K. (2015) Estimation of herbicide species sensitivity distributions using singlespecies algal toxicity data and information on the mode of action. Environmental Toxicology and Chemistry, 34, 677-684.

Oksanen, J., Blanchet, F. G., Kindt, R., Legendre, P., Minchin, R., O’Hara, R. B. et al. (2013) Package 'vegan' - Community ecology package. http://cran.r-project.org/web/ packages/vegan/vegan.pdf, last accessed19/05/2014.

Owen, M. D. K., 2008. Weed species shifts in glyphosate-resistant crops. Pest Management Science, 64, 377-387.

Parish, D. M. B., Hawes, C., Hoad, S. P., Iannetta, P. P. M., Squire, G. R. (2009) The contribution of arable weeds to biodiversity, in Weeds: Management, Economic Impacts and Biology (ed R. V. Kingely), Nova Science Publishers, New York, 61-76.

Peres-Neto, P. R., Legendre, P., Dray, S., Borcard, D. (2006) Variation partitioning of species data matrices: estimation and comparison of fractions. Ecology, 87, 2614-2625.

Pinke, G., Karacsony, P., Czucz, B., Botta-Dukat, Z., Lengyel, A. (2012) The influence of environment, management and site context on species composition of summer arable weed vegetation in Hungary. Applied Vegetation Science, 15, 136-144.

Pyšek, P., Jarošík, V., Zdeněk, K., Chytrý, M., Wild, J., Tichý, L. (2005) Effects of abiotic factors on species richness and cover in Central European weed communities. Agriculture, Ecosystsems and Environment, 109, 1-8.

Pyšek, P., Lepš, J. (1991) Response of a weed community to nitrogen fertilization: a multivariate analysis. Journal of Vegetation Science, 2, 237-244.

Rau, D., Schramm, H., Wunderlich, J. (2000) Die Leitbodenformen Thüringens. 2. ed. (ed Thüringer Landesanstalt für Geologie), Weimar, Germany, Geowissenschaftliche Mitteilungen von Thüringen, supplement 3.

R Development Core Team (2010) R: A language and environment for statistical computing, Vienna, Austria, R Foundation for Statistical Computing. http://www.R-project.org.

Roßberg, D. (2011) Erhebungen zur Anwendung von Pflanzenschutzmitteln in der Praxis im Jahr 2011. Journal für Kulturpflanzen, 65, 141-151.

Roßberg, D., Gutsche, V., Enzian, S., Wick, M. (2002) Neptun 2000 - Erhebung von Daten zum tatsächlichen Einsatz chemischer Pflanzenschutzmittel im Ackerbau Deutschlands. Berichte aus der biologischen Bundesanstalt für Land und Forstwirtschaft, 98.

Seifert, C., Leuschner, C., Meyer, S., Culmsee, H. (2014) Inter-relationships between crop type, management intensity and light transmissivity in annual crop systems and their effect on farmland plant diversity. Agriculture, Ecosystems and Environment, 195, 173-182.

Seufert, V., Ramankutty, N., Foley, J. A. (2012) Comparing the yields of organic and conventional agriculture. Nature, 485, 229-234.

Sibbesen, E. (1977) A simple ion-exchange resin procedure for extracting plant-available elements from soil. Plant and Soil, 46, 665-669.

Smart, S. M., Thompson, K., Marrs, R. H., Le Duc, M. G., Maskell, L. C., Firbank, L. G. (2006) Biotic homogenization and changes in species diversity across human-modified ecosystems. Procedings of the Royal Society B, 273, 2659-2665.

Smith, R. G., Mortensen, D. A., Ryan, M. R. (2009) A new hypothesis for the functional role of diversity in mediating resource pools and weed-crop competition in agroecosystems. Weed Research, 50, 37-48.

Sparkes, D. L., Jaggard, K. W., Ramsden, S. J., Scott, R. K. (1998) The effect of field margins on the yield of sugar beet and cereal crops. Annals of Applied Biology, 132, 129-142.

Storkey, J., Meyer, S., Still, K. S., Leuschner, C. (2012) The impact of agricultural intensification and land-use change on the European arable flora. Proceedings of the Royal Society B: Biological Sciences, 279, 1421-1429.

Sutcliffe, O. L., Kay, Q. O. N. (2000) Changes in the arable flora of central southern England since the 1960s. Biological Conservation, 93, 1-8. 
Tang, L., Wan, K, Cheng, C., Li, R., Wang, D., Pan, J., Tao, Y., Xie, J., Chen, F. (2014) Effect of fertilization patterns on the assemblage of weed communities in an upland winter wheat field. Journal of Plant Ecology, 7, 39-50.

Teasdale, J. R., Beste, C. E., Potts, W. E. (1991) Response of weeds to tillage and cover crop residue. Weed Science, 39, 195-199.

TEEB (2010) The economics of ecosystems and biodiversity: mainstreaming the economics of nature: a synthesis of the approach, conclusions and recommendations of TEEB. Progress Press, Malta

Walker, K. J., Critchley, C. N. R., Sherwood, A. J., Large, R., Nuttall, P., Hulmes, S. et al. (2007) The conservation of arable plants on cereal fields margins: An assessment of new agri-environmental scheme options in England, UK. Biological Conservation, 136, 260-270.

Wilmanns, O. (1998) Ökologische Pflanzensoziologie - Eine Einführung in die Vegetation Mitteleuropas. 6. ed., Quelle \& Meyer, Wiesbaden.

Wilson, P. J., Aebischer, N. J. (1995) The distribution of dicotyledonous arable weeds in relation to distance from the field edge. Journal of Applied Ecology, 32, 295-310. 


\title{
Chapter 3
}

Seifert, C., Leuschner, C., Meyer, S. \& Culmsee, H. (2014)

\section{Inter-relationships between crop type, management intensity and light transmissivity in annual crop systems and their effect on farmland plant diversity}

\author{
Agriculture, Ecosystems \& Environment 195: 173-182 \\ http://dx.doi.org/10.1016/j.agee.2014.05.022
}

\section{Abstract}

The recent boost of energy cropping in Central and Western Europe has greatly increased the demand for farmland leading to rapid land use change in many cultural landscapes. First-generation energy crops are now cultivated at more than $15 \%$ of Germany's arable land, but the consequences of this change in crop frequencies for agro-biodiversity are largely unknown. Concerns have been raised that this development might accelerate biodiversity loss due to high crop cover and reduced light availability in energy crop stands which could further deteriorate the growing conditions for declining arable plant species. We analysed the transmissivity for photosynthetically active radiation (TPAR) in conventionally managed maize and oilseed rape fields (energy crops) and winter cereal fields (food/fodder crops) in Central Germany and contrasted it with TPAR measured in wheat fields managed according to agri-environmental schemes (AES). Secondly, we analysed the relation between light intensity and arable plant diversity metrics with respect to effects of field management and geographical differences. Light availability was lowest in maize stands (6\% TPAR) followed by winter cereals and oilseed rape (10-13\%). Field margins were brighter than field centres (17\% vs. $10 \%$ ). Highest light transmissivity was measured on AES fields (57\%), which was associated with elevated plant diversity. Light availability explained a significant fraction of the variation in species richness also on conventionally managed field margins $\left(R^{2}=8 \%\right)$. Effects of light availability on community composition were found only when the least intensive systems (margins of conventional and AES wheat fields) were analysed. The main detrimental effect of the expansion of energy cropping on farmland habitat diversity is the loss of extensively managed farmland where light availability is higher. Reduced fertilizer use on conventional field margins will increase light availability and thus improve habitat conditions for arable plant species. 


\subsection{Introduction}

During the last decade, new political frameworks for energy supply and agricultural production have led to large-scale changes in the relative frequency of major crop types grown in Western and Central Europe which fuelled the conversion of extensively managed fields, fallow land, pastures and meadows to intensively managed crop systems (Nitsch et al., 2012; Steinmann and Dobers, 2013). One major driver behind these changes are subsidies paid for the cultivation of energy crops (Charles et al., 2013; Khanna and Chen, 2013) which have been advocated by scientists and politicians as a tool to reduce $\mathrm{CO}_{2}$ emissions for mitigating climate change (BMU and BMELV, 2010; IPCC, 2011).

Germany has declared particularly ambitious goals for replacing fossil fuels by renewable energies and the government pushes the transition by strong financial support (Britz and Delzeit, 2013). As a consequence, the area cultivated with energy crops in Germany tripled from less than 0.7 million ha in 2000 to 2.1 million ha in 2012 equalling about 18\% of the arable land (FNR, 2013a). This rapid expansion is currently mostly related to annual ('first-generation') energy crops ( $>90 \%$ of all energy crops grown on farmland) as these can be cultivated and handled with well-established, widely available machinery (FNR, 2013a, b). The two major energy crops in Germany are maize (Zea mays L.) and oilseed rape (Brassica napus, L.) (FNR, 2013a, b). In 2012, maize for biogas production (representing $32 \%$ of the total maize acreage) was grown on approximately $7 \%$ of the arable land, and oilseed rape for biofuel and vegetable oil (representing $70 \%$ of the total rapeseed acreage) was grown on $8 \%$ of the arable land (Destatis, 2013; FNR, 2013a, b). Political strategies project that the proportion of land used for energy crop cultivation might increase up to 34\% by 2020 (BMU and BMELV, 2010). This fundamental change in crop frequencies and land use intensity will also alter the environmental conditions determining the biodiversity in bioenergy landscapes.

Light is arguably the most important resource affecting the growth and survival of the arable flora. It determines photosynthetic carbon gain and regulates developmental processes such as seed dormancy, germination, and photomorphogenesis (Ballaré and Casal, 2000; Holt 1995). Over a broad range of light intensities, productivity increases linearly with the amount of absorbed photosynthetically radiation (PAR, 380-760 nm). While the low-input cropping systems of the past were characterised by relatively high light transmission through the crop, low light availability is likely an important limiting factor for arable plant growth and survival in the dark understory of modern crop stands (Kruk et al., 2006; Olsen et al., 2005). Reduced radiation transmission through the crop can alter the competitive ability of arable plants and crops (Bornkamm, 1961; Liu et al., 2009) and may affect other environmental factors, which vary with stand density and related radiation transmission, such as air humidity and air temperature in the stand interior.

Agricultural ecosystems are unique in the way that humans shape habitat conditions more strongly than in any other ecosystem (Ellenberg and Leuschner, 2010). More than climate and geological 
conditions, the choice of crop and the type of field management determine the light regime in crop stands (Ellenberg and Leuschner, 2010; van Elsen, 1994). The importance of light availability for the structure and composition of arable plant assemblages has already been emphasized by Rademacher $(1939,1950)$, but has led to only few empirical investigations thereafter (e.g. Kruk et al., 2006; Liu et al., 2009; Olsen et al., 2005). Certainly, large-scale agricultural intensification and changes in crop rotations in many regions of Central and Western Europe in the last decades must have had profound effects on the light regime in and below crop stands at the field and landscape scale. In particular, concerns have been widely raised that light availability in maize stands is reduced as compared to other commonly grown crops, affecting farmland plant diversity. The sustainability of high-input maize production to fuel biogas plants has therefore been questioned. A diverse arable flora may not only help to halt erosion and reduce nitrate leaching, it is also an important food resource and/or breeding habitat for the pollinating and pest-controlling insects and birds of the agricultural landscape (Jordan and Vatovec, 2004; Marshall et al., 2003; Parish et al., 2009). The role of altered light conditions in explaining the large losses in farmland biodiversity during the past 50 years (e.g. Fried et al., 2009; Meyer et al., 2013; Storkey et al., 2012; Sutcliffe and Kay, 2000) has not yet been quantified and its relative importance with respect to other chemical and mechanic stressors in modern cropping systems remains unknown.

Previous PAR measurements in modern crop stands were primarily done for the purpose of parameterizing of crop growth and yield models (Daughry et al., 1992; Gallo et al., 1995; Hipps, 1983), but did not deal with weed growth conditions. Our study for the first time links light measurments in modern high-yield crop stands to the weed vegetation using a systematic, replicated sampling design. We did this in regular cropland used for food, fodder or energy production and did not study experimental stands. Apart from a few exemplary measurements (van Elsen, 1994), such an approach has not been adopted before. This will allow drawing conclusions on the influence of changes in crop rotations on the light regime in crop stands and on weed growth conditions on the landscape level.

We addressed the following questions: (1) How does the light regime at ground level, expressed as PAR transmissivity (TPAR), vary between cropping systems? (2) Which spatial scale of observation contributes most to the variation in light conditions? (3) How much of the variation in TPAR in arable fields can be explained by crop performance (crop cover), management (choice of crop, conventional vs. AES cropping) and/or regional effects? (4) How does TPAR relate to the structure and composition of arable plant assemblages (weed cover, species richness and community composition) in different cropping systems in comparison to othe explanatory factors such as field management and study region? 


\subsection{Methods}

\subsubsection{Study area}

The fields investigated were selected in two regions in the central uplands of Germany, which are characterized by a hilly countryside with plains highly suitable for productive arable farming (Fig. 3.1). The first study region, the Lower Saxon hills (LS), is situated in the county of Göttingen (1118 $\mathrm{km}^{2}$; elevation 104-579 m a.s.1.). Mean annual precipitation is $650 \mathrm{~mm}$ and mean annual temperature $8.7^{\circ} \mathrm{C}$ (DWD, 2013). The second study regions is located in the agricultural plains of the Thuringian Basin (TB; $1058 \mathrm{~km}^{2} ; 134-413 \mathrm{~m}$ a.s.l.). The climate in the Thuringian Basin is drier (mean annual precipitation: $500-550 \mathrm{~mm}$ ) and slightly warmer (mean annual temperature: $9.2^{\circ} \mathrm{C}$ ) than in the Lower Saxon hills (DWD, 2013). Due to differences in agricultural policies on both sides of the inner German border before 1990, the agricultural landscapes in the two study regions differ structurally. The proportion of farmland is higher in the Thuringian Basin than in the Lower Saxon hills (78\% vs. $44 \%$, respectively) and fields are on average larger [average size of an administrative field unit 18.8 ha (TB) vs. 6.6 ha (LS)].

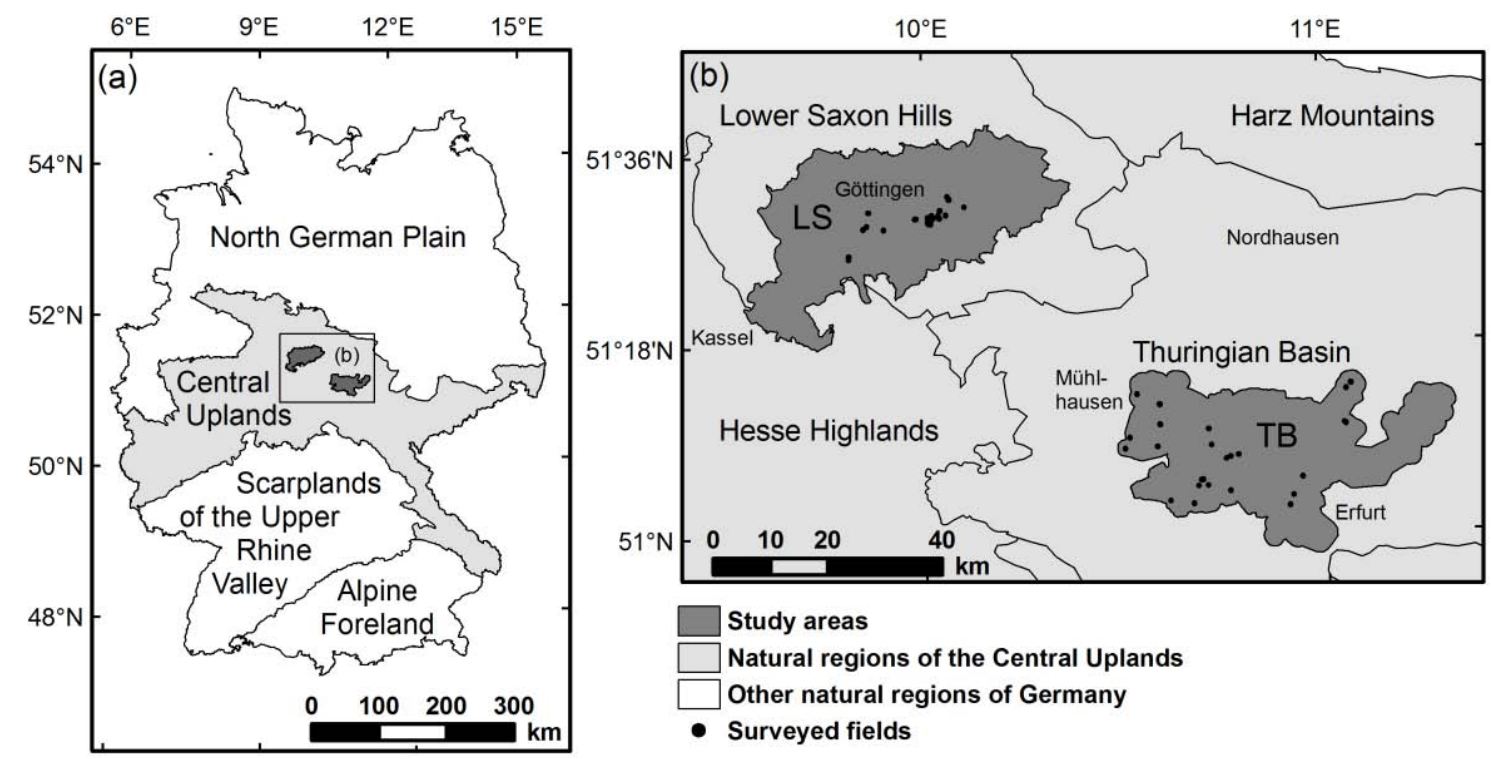

Fig. 3.1 Study areas in Lower Saxony and Thuringia, Germany. (a) Location in Germany; (b) delimitation of the study areas within the Lower Saxon hills (LS) and the Thuringian Basin (TB) with the distribution of the 25 surveyed fields in each study area (dots). The map is based on Universal Transverse Mercator (UTM) projection, zone $32 \mathrm{~N}$ (WGS 1984). Biogeographical boundaries are adopted from Meynen and Schmithüsen (1953-1962). 


\subsubsection{Sampling design}

A total of 50 arable fields, equally distributed across both study regions, were selected for vegetation surveys, which were conducted in the summers of 2011 and 2012. In each region, five fields of four different crops (maize, oilseed rape, winter barley and winter wheat) under conventional management (i.e. application of fertilizers and herbicides according to common agricultural practice) were selected. We included only fields with a closed crop stand without any signs of crop growth failure. We did not distinguish between fields on which maize or oilseed rape was specifically grown for the purpose of energy production and fields where these crops were cultivated for food/fodder production. Interviews with farmers and energy plant operators, consultation of the agricultural literature (Lütke-Entrup and Schäfer, 2011) and earlier analyses of available field management data for 28 maize fields (Seifert et al., unpublished data) revealed not differences in fertilizer application or weed management between these two types of product usage. As far as oilseed rape is concerned, farmers are often not even aware of what their product is finally going to be used for by the purchaser. Impacts of energy cropping on biodiversity were thus assumed to arise exclusively from changes in the relative frequency of the crops in time and space and from the conversion of extensively managed fields, fallows, pastures and meadows to intensively managed arable land. Additionally, five winter wheat fields, which were managed according to an agri-environmental scheme (AES) for the protection of rare arable plant species, were studied in each region. On AES fields, no herbicides or fertilizers had been applied in the year of study, but sowing and tillage was done with the same intensity and timing as on adjacent conventionally managed fields.

On each field, two plots of $2 \mathrm{~m} \times 50 \mathrm{~m}$ (i.e. $100 \mathrm{~m}^{2}$ ) were established for the surveys, the first one along the field margin (FM, starting with the first crop row) and the second one in the field interior (FI, with at least $10 \mathrm{~m}$ distance to the field edge parallel to the first plot). $100 \mathrm{~m}^{2}$ is a common relevé size used in Central European arable field surveys (Meyer et al., 2013). Most AES fields were only 12$20 \mathrm{~m}$ wide; thus, the plots in the field interior were placed with 6-9 $\mathrm{m}$ distance to the field edge. Field surveys, which included vegetation sampling and PAR measurements, were conducted in the period when the crops were in their respective milk stages (around 3-6 weeks before harvesting) and crop cover was estimated to be at its maximum (i.e. winter barley: 8-16 June; oilseed rape: (24-29 June; winter wheat 14 June-8 July; maize: 30 July-8 August).

\subsubsection{Sampling of arable weed assemblages}

The cover and composition of all vascular plant species was recorded in the $100 \mathrm{~m}^{2}$ plots using the Braun-Blanquet cover abundance scale consisting of nine classes according to Wilmanns (1998). Additionally, total crop cover and total weed cover were estimated visually. Species nomenclature follows Buttler et al. (2013). A comprehensive species list is given in appendix 3.A. 


\subsubsection{PAR measurement and calculation of TPAR}

Quantum sensors (LI-190 Quantum Sensor, LI-COR, Lincoln, Nebraska, USA; Biggs et al., 1971) were used to measure the flux density of photosynthetically active radiation (PAR, expressed as $\mu \mathrm{mol}$ photons $\mathrm{m}^{-2} \mathrm{~s}^{-1}$ ) above and below the crop canopy around noon time (10 a.m. -3 p.m.) on days with homogeneous sky conditions without rapid fluctuation of incident radiation. Although the sky conditions and sun angle necessarily varied between different measurement days, we are confident that our data are not biased by these variations, as Hipps (1983) showed that in late-season crop stands with high leaf area indices, measurements of PAR interception and transmission are not influenced by sun angle and cloud cover.

To measure how much TPAR was available for weed growth below the crop canopy, one PAR sensor was positioned at ground level $\sim 15 \mathrm{~cm}$ above the soil surface in order to record the light climate experienced by the weeds (transmitted PAR; PAR trans). A second PAR sensor was placed $\sim 50 \mathrm{~cm}$ above the crop canopy for synchronously measuring incident PAR flux density $\left(\mathrm{PAR}_{\text {inc }}\right)$. To avoid biased readings, sensors were placed with great care in the stand in order to avoid damaging the crop canopy. The mobile sensor was mounted at the end of a $1.5 \mathrm{~m}$-long stick which allowed conducting the measurements at a distance from the operator where he influenced radiation flux density only minimally. Both sensors rotated freely so that they were always in horizontal position. In each survey plot, ten measuring points were randomly selected and five consecutive light measurements taken at time steps of $\sim 5 \mathrm{~s}$ at each point. Incident and transmitted PAR were recorded synchronously with a LI1400 data logger (LI-COR, Lincoln, NE, USA). PAR transmissivity (TPAR, in \%) was calculated as

$$
\mathrm{TPAR}=\left(\mathrm{PAR}_{\text {trans }} / \mathrm{PAR}_{\text {inc }}\right) \times 100 \quad(\text { eq. } 3.1)
$$

Mean TPAR per plot was obtained by averaging over the five consecutive measurements per point and subsequently calculating the mean across the ten points per plot. Both sensors were calibrated against each other before the start of the measurements.

\subsubsection{Statistical analyses}

\subsubsection{Analysis of transmissivity data}

Differences in TPAR (and also in the vegetation parameters crop cover, weed cover, species richness and light demand) between the different cropping systems were analysed using the nonparametric Behrens-Fisher test for multiple comparisons (R-package npmc; Helms and Munzel, 2009). We used Wilcoxon's signed rank test for paired samples to test for differences between the FI and the FM for the different cropping systems. All statistical tests in this study were performed with $\mathrm{R}$ software, version 2.11.1 (R Development Core Team, 2010). 
Under the assumption that the spatial scale of observation in this study - within-field, between fields, between cropping systems and between regions - increases with each step in this sequence, we used variance component analysis (VCA) with nested random effects to analyse at which scale most of the variation in TPAR originates (R-package lme4; Bates, 2013; Crawley, 2007; Searle et al., 2006). Measurement points were nested within fields, fields within cropping systems (only for analyses across different crop types) and cropping systems or fields within study regions. Due to the particular error structure of percentage data, we expected binomial errors and used a logit link function.

To examine how much of the variation in TPAR in the arable fields was explained by crop cover (in $\%$ ), field management (crop; conventional management vs. AES) and region, we conducted linear regression analyses (R-package: vegan; Oksanen et al., 2011). For quantifying the intersections between factors (i.e. the fractions of variation statistically not attributable to any single factor; not referring to interactions), we used variance partitioning (Legendre, 2008), when several factors were significant.

\subsubsection{Analysing the effects of TPAR on the diversity of weed assemblages}

The arable plant assemblages were described by their total weed cover, species richness and community composition. The crop itself, any woody species (including Rubus fruticosus agg.), representatives of volunteer grain (Brassica napus, Hordeum vulgare, Triticum aestivum, Secale cereale and $\times$ Triticosecale) and specimens belonging to one of ten taxa represented with several species in the data set and which were not identifiable to species level, were excluded from the analyses concerning the arable plant assemblages (cp. appendix 3.A). Two plots from the FI (conventional wheat and barley) had to be excluded from certain analyses (CCA) due to lacking weed species in the plot.

Variance partitioning (Legendre, 2008) was used to quantify the explanatory power of TPAR for each of the four response variables (weed cover, species richness and community composition) in relation to field management factors and regional effects. Based on linear regressions (for weed cover and species richness) and canonical correspondence analyses (CCA, for community composition; Rpackage vegan), we obtained (1) the fractions of variance in the data set explained, if only one of the three explanatory factors [TPAR, management (crop; conventional vs. AES), region (LS vs. TB)] was considered, or if several factors were significant, and (2) the fractions of variance shared by any combination of two or all three factors. 


\subsection{Results}

\subsubsection{TPAR variability within and between different cropping systems}

The PAR transmissivity of conventionally managed fields did not differ between the two study regions when analysed separately for the four crops and for the field interior and the field margin (appendix 3.B); the data were thus pooled in subsequent analyses. Across all 40 conventional fields, TPAR showed considerable variation (range in the field interior: 1.9-18.9\%, mean: $9.9 \% \pm 0.7 \mathrm{SE}$; field margin: $4.3-40.3 \%$, mean: $16.9 \% \pm 1.3$; Fig. 3.2a, appendix 3.C). The coefficients of variation in the four crops ranged between $25-47 \%$ in the field interior and $35-61 \%$ at the field margin. TPAR was lower in maize fields than in the other three crops both in the interior (means: 5.9 vs. 10-13\%; difference significant to oilseed rape) and at the margin (means: 10.9 vs. 18-19\%; difference significant to oilseed rape and barley). TPAR was $50-80 \%$ higher at the margin than in the field interior.

Compared to conventionally managed wheat fields, TPAR in AES wheat fields was 5.5 fold (field interior) and 3.8 fold (field margin) higher and more variable between the fields and regions (range in the field interior: $35.1-83.3 \%$, mean $=56.9 \% \pm 4.9$; range at the field margin: $39.6-94.1 \%$, mean: $69.1 \% \pm 6.1$; Fig. 3.3a). Conventional and AES wheat fields contrasted also with respect to the frequency distribution of TPAR values (Fig. 3.4). Data showed positively skewed distributions with clumping of values below 20\% TPAR in the conventional fields, but Gaussian or negatively skewed distributions with a modus $>50 \%$ TPAR in the AES fields.
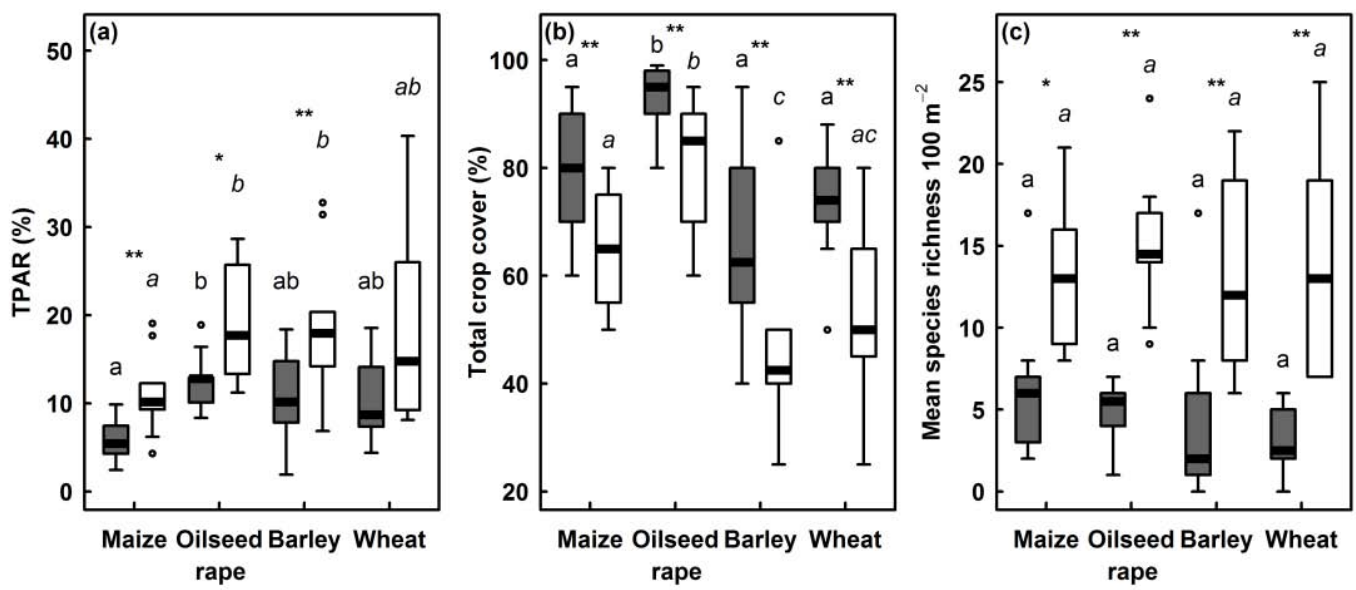

Fig. 3.2 Differences in (a) PAR transmissivity (TPAR), (b) total crop cover, and (c) mean number of weed species $100 \mathrm{~m}^{-2}$ of the weed assemblages (cover weighted) in the field interior (FI, grey boxplots) and at the field margin (FM, white boxplots) of four different crops in conventionally managed arable fields in the central uplands of Germany. Different letters indicate significant differences between crops (BehrensFisher test, $p \leq 0.05, \mathrm{n}=10$ fields per group) for the FI (regular letters) and the FM (italic letters). Asteriscs indicate significant differences between plots in the FI and at the FM for a crop (Wilcoxon signed rank test; ${ }^{*} p \leq 0.05 ; * * p \leq 0.01 ; \mathrm{n}=10$ per group). 


\subsubsection{The spatial origin of TPAR variation}

Hierarchical variance component analysis (VCA) confirmed that the variation in light conditions in conventionally managed arable fields originated at the local rather than the regional scale (Table 3.1). Total TPAR variance was similarly large in the interior and at the margin of conventional fields, but the proportion of variance assignable to the different spatial scales differed. At field margins, variability was highest between different fields of a crop (48\%) and differences between crops contributed only a small fraction of variance $(9 \%)$. In the field interior, the choice of crop was more important $(21 \%)$ and between-field variability was reduced (36\%). Within-field variability contributed similarly at field margins $(42 \%)$ and in the field interior (43\%).

Separate analyses for maize, oilseed rape, barley and wheat revealed differences in the origin of variation between the crops. The highest TPAR variation (within-field to region) was registered in conventional wheat fields, the lowest in oilseed rape in the field interior and in barley at the field margin. In barley fields, between-field variation was of particular importance (field interior: $92 \%$, field margin: $73 \%$ ). For the other three crops, the contribution of between-field variation was low in the field interior (18-29\%), but increased towards the field margin (32-54\%). The region explained only a very small fraction of TPAR variation in the conventionally managed crops and a significant effect was only detected for conventional wheat (field interior) and oilseed rape (field margin) but not in the other crops.
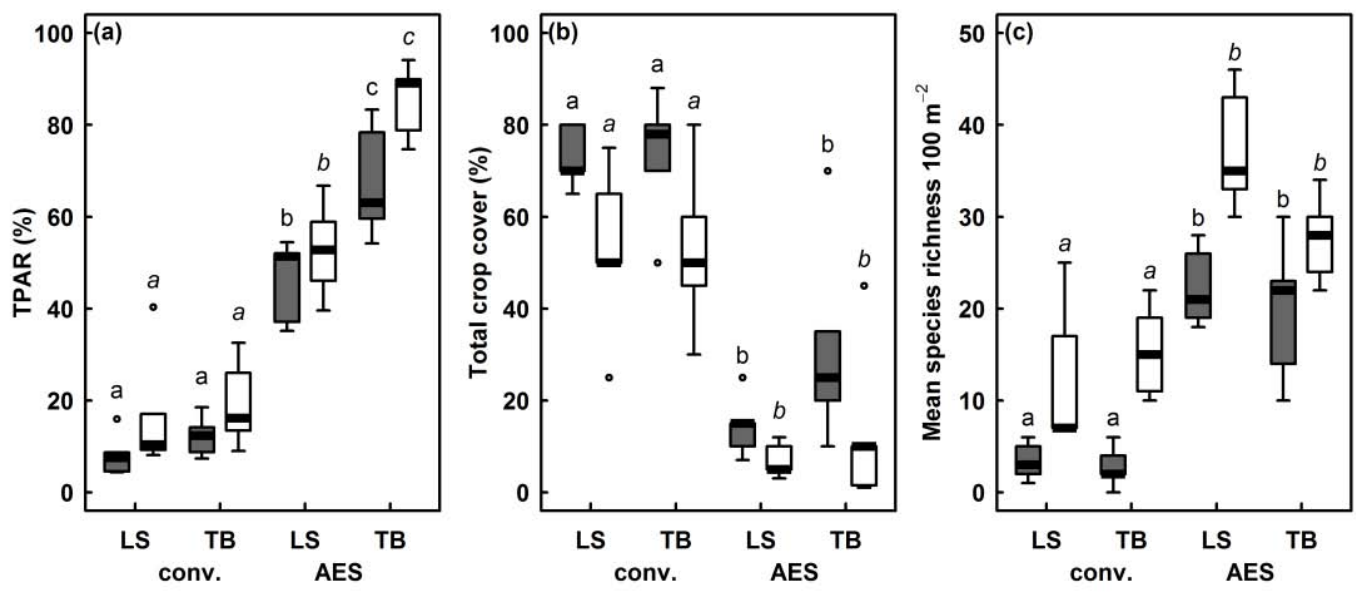

Fig. 3.3 Differences between conventionally managed wheat fields (conv., $\mathrm{n}=10$ ) and wheat fields managed according to an agri-environmental scheme (AES, $n=10)$ in the Lower Saxon hills (LS) and in the Thuringian Basin (TB), distinguishing between plots in the field interior (FI, grey boxplots) and at the field margin (FM, white boxplots) in (a) TPAR (in \%), (b) total crop cover (in \%), and (c) mean species richness per plot. Different letters indicate significant differences between crops (Behrens-Fisher test, $p \leq 0.05, \mathrm{n}=5$ per group) for the FI (regular letters) and the FM (italic letters). 
Table 3.1 Variance of TPAR attributable to within-field, between-field, between-crop and between-region variation according to hierarchical variance component analysis (VCA with binomial errors and logit links); the nesting structure consisted of measurement points within fields with different kinds of crops in the two study regions added tot the model as random variables. Proportions (in \%) of the total variance are given in brackets. All fields, all five studied cropping systems; Conv., conventionally managed; AES, managed under an agri-environmental scheme.

\begin{tabular}{|c|c|c|c|c|c|c|c|c|c|c|c|}
\hline & \multirow[b]{2}{*}{$n$} & \multicolumn{5}{|c|}{ Field interior (FI) } & \multicolumn{5}{|c|}{ Field margin (FM) } \\
\hline & & Within field & $\begin{array}{c}\text { Between } \\
\text { fields }\end{array}$ & $\begin{array}{c}\text { Between } \\
\text { crops }\end{array}$ & $\begin{array}{l}\text { Between } \\
\text { regions }\end{array}$ & Total & $\begin{array}{l}\text { Within } \\
\text { field }\end{array}$ & $\begin{array}{c}\text { Between } \\
\text { fields }\end{array}$ & $\begin{array}{c}\text { Between } \\
\text { crops }\end{array}$ & $\begin{array}{c}\text { Between } \\
\text { regions }\end{array}$ & Total \\
\hline All fields & 50 & $0.29(14.8)$ & $0.24(12.6)$ & $1.41(72.7)$ & $0.00(0.0)$ & 1.94 & $0.27(12.8)$ & $0.32(15.5)$ & $1.51(71.7)$ & $0.00(0.0)$ & 2.10 \\
\hline Conv. crops & 40 & $0.27(43.4)$ & $0.22(35.6)$ & $0.13(21.1)$ & $0.00(0.0)$ & 0.62 & $0.28(42.4)$ & $0.32(48.2)$ & $0.06(9.4)$ & $0.00(0.0)$ & 0.66 \\
\hline Wheat (conv., AES) & 20 & $0.42(14.8)$ & $0.24(8.4)$ & $2.20(76.8)$ & $0.00(0.0)$ & 2.86 & $0.34(10.6)$ & $0.47(14.8)$ & $2.37(74.7)$ & $0.00(0.0)$ & 3.18 \\
\hline Maize & 10 & $0.35(70.7)$ & $0.15(29.3)$ & & $0.00(0.0)$ & 0.50 & $0.40(67.8)$ & $0.19(32.2)$ & & $0.00(0.0)$ & 0.59 \\
\hline Oilseed rape & 10 & $0.19(79.3)$ & $0.05(20.7)$ & & $0.00(0.0)$ & 0.24 & $0.20(51.8)$ & $0.17(42.8)$ & & $0.02(5.4)$ & 0.39 \\
\hline Barley & 10 & $0.04(8.2)$ & $0.43(91.8)$ & & $0.00(0.0)$ & 0.47 & $0.10(27.3)$ & $0.27(72.7)$ & & $0.00(0.0)$ & 0.37 \\
\hline Wheat (conv.) & 10 & $0.50(64.8)$ & $0.14(17.6)$ & & $0.13(17.6)$ & 0.77 & $0.43(46.5)$ & $0.50(53.5)$ & & $0.00(0.0)$ & 0.93 \\
\hline Wheat (AES) & 10 & $0.36(38.9)$ & $0.34(37.2)$ & & $0.21(23.9)$ & 0.91 & $0.23(16.2)$ & $0.36(25.7)$ & & $0.81(58.1)$ & 1.40 \\
\hline
\end{tabular}


Adding AES fields to the sample more than tripled the total variance of TPAR. Between-region variation was an important source of TPAR variation in AES wheat fields contributing with 58\% (field margin) and $24 \%$ (field interior) to total variation (Table 3.1). Thus, AES fields are an important source of landscape-scale heterogeneity in the cropland light regimes.

\subsubsection{Drivers of TPAR in arable fields}

TPAR and management factors were mutually related. The regression analyses showed that field management factors (crop type and management intensity) best explained the variation in TPAR (Table 3.2). The crop type explained 23\% of the TPAR variation in the interior of conventional fields and management intensity (conventional vs. AES) explained $81 \%$ in the interior and $73 \%$ at the margins when wheat fields were analysed separately. Crop cover co-varied tightly with management intensity, but was found to explain less variation (field interior: 59\%, field margin: 51\%). Management intensity still explained about $20 \%$ of TPAR variation both in the field interior and at the margins after controlling for the effect of crop cover. In conventionally managed fields, estimated crop cover varied between $40-99 \%$ in the field interior (mean: $78 \% \pm 5 \mathrm{SE}$ ) and between $25-95 \%$ at the margin (mean: $61 \% \pm 6$ ) (Fig. 3.2b; difference significant at $p \leq 0.001$; appendix 3.C). On AES wheat fields, total crop cover was much lower (FI, mean: $23 \% \pm 6$; FM, mean: $10 \% \pm 4$; Fig. 3.3b) than on conventional wheat fields in both study regions (Fig. 3.3b; difference significant at $p \leq 0.01$; appendix 3.C). Differences between sampling regions did not explain the variation in TPAR.
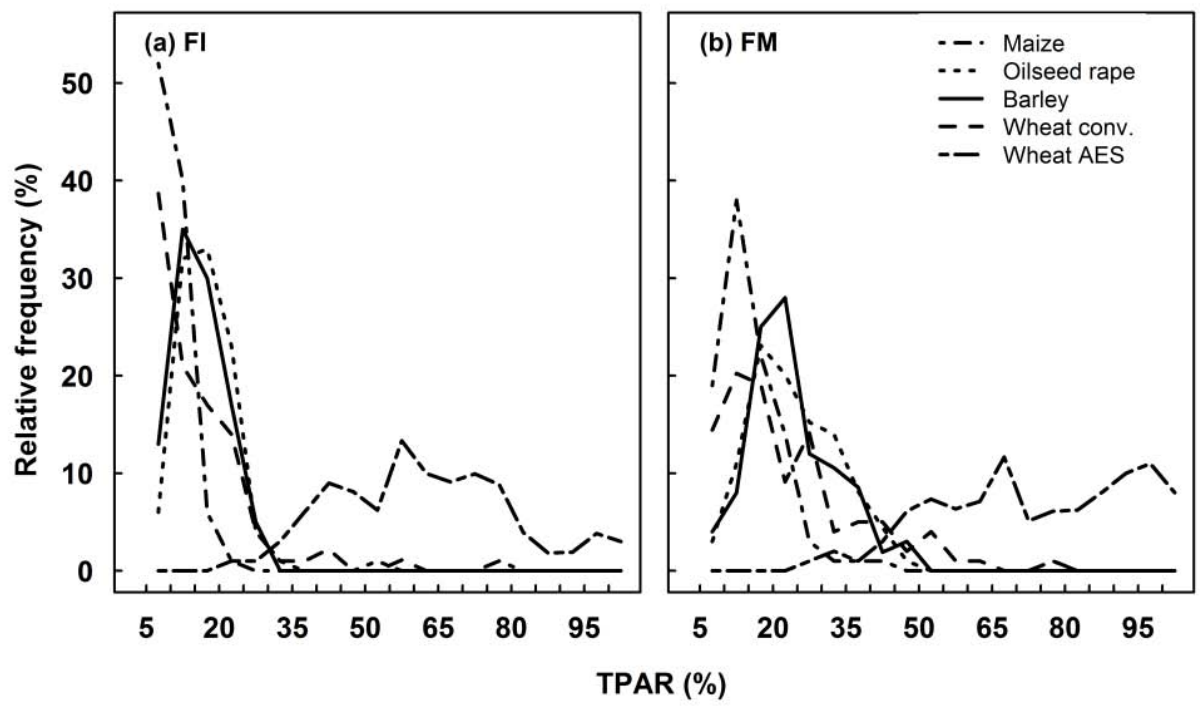

Fig. 3.4 Relative frequency of classes of PAR transmissivity (TPAR) to the soil surface (interval width: 5\%) in four different conventionally managed crops and winter wheat managed according to an agri-environmental scheme (AES) for (a) the field interior and (b) the field margin in the central uplands of Germany ( $\mathrm{n}=10$ fields per category). 
Table 3.2 Fractions of the variation in TPAR explained by crop cover, management factors (crop, management intensity: conventional management (conv.) vs. agri-environmental schemes (AES)), and region (Lower Saxon hills vs. Thuringian Basin), in the field interior (FI) and at the field margin (FM) of conventionally managed fields with four different crops and of wheat fields under conventional and AES management, assessed in the central uplands of Germany. Fractions are the adjusted $R^{2}$ from redundancy analyses (RDA). Intersections were obtained from variation partitioning (Legendre, 2008).

\section{TPAR}

\begin{tabular}{|c|c|c|}
\hline & FI & FM \\
\hline Conv. crops & 40 & 40 \\
\hline Crop cover + Management + Region & $35.2^{* *}$ & $17.4^{*}$ \\
\hline Crop cover (total) & ns & $\mathrm{ns}$ \\
\hline Management (total) & $23.4^{* *}$ & $\mathrm{~ns}$ \\
\hline Region (total) & ns & ns \\
\hline Crop cover $\cap$ Management & - & - \\
\hline Crop cover $\cap$ Region & - & - \\
\hline Management $\cap$ Region & - & - \\
\hline Crop cover $\cap$ Management $\cap$ Region & - & - \\
\hline Wheat fields (conv., AES) & 20 & 20 \\
\hline Crop cover + Management + Region & $87.0^{* *}$ & $80.4^{* * *}$ \\
\hline Crop cover (total) & $59.1^{* \cdots}$ & $\mathbf{5 0 . 5}^{*}$ \\
\hline Management (total) & $81.3^{* * *}$ & $72.9^{* * *}$ \\
\hline Region (total) & ns & ns \\
\hline Crop cover $\cap$ Management & 60.2 & 53.0 \\
\hline Crop cover $\cap$ Region & - & - \\
\hline Management $\cap$ Region & - & - \\
\hline Crop cover $\cap$ Management $\cap$ Region & - & - \\
\hline
\end{tabular}

$\cap$ indicates that the variation explained is shared between the respective components. These intersections cannot be tested for significance (Legendre, 2008). Intersections were only assessed when all components explained a significant fraction of the variation in the single factor models. Models were tested with ANOVA (ns, $p>0.05 ; *, p \leq 0.05 ; * *, p \leq 0.01$ ).

\subsubsection{Influence of TPAR on weed assemblages}

\subsubsection{Influence of TPAR on weed cover}

TPAR was not found to explain a significant part of the variation in weed cover between conventional fields, neither in the field interior nor at the margin. The total weed cover in conventionally managed fields was generally very low with on average $3 \%( \pm 2$ SE) cover in the field interior and 16\% ( \pm 3$)$ at the margin (appendix 3.C). Differences between crops or regions also did not capture a significant part of these subtle weed cover variations. 
In contrast, regression analyses showed that weed cover in the field interior was largely explained by the factors TPAR (34\%) and field management (38\%), both being highly correlated to each other, when conventional and AES wheat fields were assessed. On the other hand, none of the investigated factors explained the difference in weed cover at the field margin in conventional vs. AES wheat fields. Weed cover was with on average $38 \%( \pm 8)$ by factor 9.5 higher than in conventionally managed wheat fields (mean: $4 \% \pm 4$ ). At the margin, weed cover differed much less between AES fields (mean: $28 \% \pm 8$ ) and conventional wheat fields (mean: $17 \% \pm 4$ ). Variation in weed cover mainly seems to be driven by factors other than the ones included in this study.

\subsubsection{Influence of TPAR on species richness}

Contrary to weed cover, species richness per plot was related to TPAR when management intensity was reduced (i.e. at the margin of conventional fields and when AES fields were included in the analysis, Table 3.3). On conventional field margins, species richness increased with TPAR (correlation coefficient $R=0.32, p=0.05, \mathrm{n}=40$ ) and TPAR explained $8 \%$ of the variation in species richness. The increased variability in light conditions and the reduction of management intensity at the field margins and on AES fields was also found to go along with increased variability in species richness (Fig. 3.2c and 3.3c). When contrasting conventional and AES wheat fields, both TPAR and management intensity were highly significant explanatory factors for species richness. Both factors co-varied tightly and together explained $83 \%$ of the variation in species richness in the interior (with $73 \%$ being shared between the factors, not being exclusively attributable to either one). At the field margins, both factors together explained $50 \%$ of the variation, with $35 \%$ being shared between the factors. In contrast to the results from conventionally managed fields, species richness decreased with increasing TPAR on AES field margins where other factors than light seemed to limit plant growth (correlation coefficient $R=-0.65, p=0.04, \mathrm{n}=10$ ). In the interior of conventional fields, differences in species richness between fields were very small and neither TPAR nor crop or region explained this small variation.

Species richness per plot did not differ between the four conventional crops neither for the field margins nor for the field interior (Fig. 3.2c). Weed assemblages of AES wheat fields were, however, much more species-rich than conventionally managed wheat fields ( $p \leq 0.05$; Fig. 3.3c). Conventional fields (all crops averaged) had on average five species per plot in the interior and 14 species at the field margins, while 21 and 33 species, respectively, were recorded in the AES fields. Apart from few exceptions, we found the most species-rich conventionally managed field margins to still be less species-rich than the poorest AES field margins. There was, however, considerable overlap in species richness between conventionally managed margins and the centres of AES fields. 
We recorded a total of 157 plant species in the 100 plots, of which 155 taxa were found at the field margin and 90 in the field interior (appendix 3.A). 121 species occurred in the ten investigated AES fields and 101 species in the 40 conventionally managed fields. With 24 species restricted to the margin of conventional fields (maize: 8 species; oilseed rape: 2; winter barley: 7; winter wheat: 5) and 31 species restricted to the margin of AES fields, field margins were very important for the regional species pool. Three species were restricted to the interior of AES fields, but no species occurred solely in the interior of conventionally managed fields.

Table 3.3 Fractions of variance (adjusted $R^{2}$, in \%) explained by TPAR, management factors (crop; management intensity: conventional management (conv.) vs. agri-environmental schemes (AES), and region (Lower Saxony uplands vs. Thuringian Basin)) for total weed cover, species richness and the community composition of weed assemblages on arable fields in the central uplands of Germany. Fractions are based on redundancy analyses (RDA, for weed cover and species richness) or canonical correspondence analyses (CCA, for community composition) and intersections were obtained from variation partitioning.

\begin{tabular}{|c|c|c|c|c|c|c|}
\hline & \multicolumn{2}{|c|}{ Weed cover } & \multicolumn{2}{|c|}{$\begin{array}{l}\text { Species } \\
\text { richness }\end{array}$} & \multicolumn{2}{|c|}{$\begin{array}{l}\text { Community } \\
\text { composition }\end{array}$} \\
\hline & FI & FM & FI & FM & FI & FM \\
\hline Conv. crops & 40 & 40 & 40 & 40 & 38 & 40 \\
\hline TPAR + Management + Region & ns & ns & ns & ns & $10.4^{*}$ & $13.2^{* * *}$ \\
\hline TPAR (total) & ns & ns & $\mathrm{ns}$ & $7.7^{*}$ & ns & ns \\
\hline Management (total) & ns & ns & ns & ns & $9.4^{*}$ & $10.1^{* *}$ \\
\hline Region (total) & ns & ns & ns & ns & $\mathrm{ns}$ & $2.3^{* *}$ \\
\hline TPAR $\cap$ Management & - & - & - & - & - & 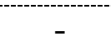 \\
\hline TPAR $\cap$ Region & - & - & - & - & - & - \\
\hline Management $\cap$ Region & - & - & - & - & - & 0.1 \\
\hline TPAR $\cap$ Management $\cap$ Region & - & - & - & - & - & - \\
\hline Wheat fields (conv., AES) $n=$ & 20 & 20 & 20 & 20 & 19 & 20 \\
\hline TPAR + Management + Region & $31.8^{*}$ & $\mathrm{~ns}$ & $83.3^{* * *}$ & $62.2^{* *}$ & $12.4^{* * *}$ & $18.3^{* * *}$ \\
\hline TPAR (total) & $3^{3.6}$ & ns & $\mathbf{7 3 . 8}^{* N^{*}-}$ & 35.2 & ns & 8.0 \\
\hline Management (total) & $37.9^{* * *}$ & ns & $79.9^{* * *}$ & $63.4^{* * *}$ & $4.0^{*}$ & $6.8^{* * *}$ \\
\hline Region (total) & ns & ns & ns & ns & $6.9^{* * *}$ & $7.4^{* * *}$ \\
\hline TPAR $\cap$ Management & 36.8 & - & 73.3 & 34.9 & - & 0.7 \\
\hline TPAR RRegion & - & - & - & - & - & 1.0 \\
\hline Management $\cap$ Region & - & - & - & - & 0 & 0 \\
\hline TPAR $\cap$ Management $\cap$ Region & - & - & - & - & - & 0 \\
\hline
\end{tabular}

$\cap$ indicates that the variation explained is shared between the respective components (i. e. it cannot be attributed exclusively to one of the components). These intersections cannot be tested for significance (Legendre, 2008). Intersections were only assessed when all components explained a significant fraction of the variation in the single factor models. Models were tested with ANOVA (ns, $p>0.05 ; *, p \leq 0.05 ; * *, p \leq 0.01$ ). FI, field interior; FM, field margin.

\subsubsection{Influence of TPAR on community composition}

A relationship between TPAR and community composition was only found when the most extensively managed cropping systems (margins of conventional and AES wheat fields) were 
assessed. Here, TPAR explained the highest fraction of the variation (8\%). The contribution of TPAR was largely independent of the fractions explained by management intensity (7\%, 1\% shared with TPAR) and region (7\%, 1\% shared with TPAR). Adonis aestivalis, Euphorbia exigua and Falcaria vulgaris are examples of species which preferred wheat fields with high TPAR, whereas Fumaria officinalis, Lamium purpureum and Myosotis arvensis were less light-demanding and occurred more often when TPAR was low.

In the conventional fields, not TPAR but the choice of crop explained the largest fraction of variation in community composition in the field interior (9\%) as well as at the field margin (10\%, Table 3.3). We found Chenopodium hybridum, Echinochloa crus-galli, Persicaria lapathifolia and Solanum nigrum to prefer maize fields over oilseed rape and winter cereals (cp. appendix 3.A). Descurainia sophia, Matricaria recutita, Myosotis arvensis, Papaver rhoeas and Thlaspi arvense are examples of species which were commonly found in oilseed rape, barley and wheat fields, but were absent in maize fields. We could not identify any species which showed a clear preference for any of the three wintersown crops (oilseed rape, barley and wheat), apart from Capsella bursa-pastoris, which was most commonly found in oilseed rape.

In addition, weed assemblages at the margin of conventional fields differed between the two study regions which explained $2 \%$ of the variation in community composition. The influence of region on the composition of the weed assemblages was even larger in AES fields ( 7 and $6 \%$ of variance explained in the field interior and at the margin, respectively) than in conventional cropping systems.

There was a large number of species regularly occurring on AES fields (frequency $>40 \%$ ) that were completely absent in conventional fields (e. g. Geranium columbinum, Euphorbia exigua, Arenaria serpyllifolia, Valerianella dentata, Medicago lupulina). Rare species, such as Adonis flammea, Bupleurum rotundifolium and Euphorbia falcata (all listed as critically endangered in Ludwig and Schnittler, 1996) were also restricted to AES fields.

\subsection{Discussion}

\subsubsection{Light transmission patterns in different cropping systems}

With average PAR transmissivities in the range of $10-13 \%$ in the field interior at the time of peak crop biomass, conventionally managed wheat, barley and oilseed rape fields are equally or less shading than temperate grasslands (Lane et al., 2000; Tappeiner and Cernusca, 1989) and less shading than closed broad-leaved forests (Ellenberg and Leuschner, 2010). Nevertheless, these modern crop stands are nowadays probably too dark for many typical light-demanding arable weed species. Experimental evidence shows that many arable species grow best at high illumination (Bornkamm, 1961; Fitter and Ashmore, 1974; Holt, 1995). Tall-growing maize, the crop with the largest increase in 
cultivation area in Germany during the recent boost of energy farming (Steinmann and Dobers, 2013), reduces transmissivity to lower levels than the other three conventional crops, and the range of transmissivities measured was smaller in maize than in all other crops. With a mean transmissivity of $6 \%$, maize fields are as dark as fertile grasslands and mature spruce forests (Ellenberg and Leuschner, 2010).

The most important TPAR gradient existing in conventional high-input cropland is the difference between field margin and interior. In general, TPAR was not only higher (average across all four conventional crops: 17\%) at the field margin than in the interior, but also more variable ranging 4 to $40 \%$ ). Field margins therefore have a higher potential to increase habitat diversity in terms of light availability than the field interior. Consequently, the TPAR reduction in maize stands is ecologically most relevant at the field margin, where the highest diversity of arable plants is usually found (Fried et al., 2009; van Elsen, 1994). We assume that the differences between field edge and field interior are attributable to a set of interacting factors which influence both light conditions and the arable flora. Due to technical and legal constraints, margins tend to receive less crop seeds, fertilizer and herbicides (Wilson and Aebischer, 1995) and crop yields are typically lower (Sparkes et al., 1998). In accordance with these findings, we found crop cover to be on average $17 \%$ higher in the interior than at the margin.

One important result of this study is that the variability in PAR transmissivity in conventionally managed fields is generated almost exclusively at the local scale, whereas regional differences in TPAR were negligible (except for the interior of wheat fields). Similarly, between-field variation within a region was of minor importance in the field interior, at least for maize, oilseed rape and wheat. We assume that between-field differences in TPAR, if they exist, mainly reflect different management practices and gradients in soil and climate conditions. Consequently, our data evidence a general homogenization of site conditions and management practices that has taken place in Central and Western Europe's farmland during the last decades. Formerly existing differences in weed management, fertilization and soil conditions across farms and regions (Meyer et al., 2013) have become less important for crop growth and TPAR in conventional cropping systems. The homogenization of habitat conditions at the local and landscape scale is a major driver of impoverishment in the regional species pools (Kohlbrecher et al., 2012; Meyer et al., 2013; Smart et al., 2006). The three-fold increase in total TPAR variance after adding the ten AES fields to the sample shows that extensively managed arable fields greatly increase the heterogeneity of light conditions inside crop stands creating ecological niches for weeds with higher light demand.

Even though field margins of conventionally managed fields also offer considerable variation in light condition, there was little overlap with light conditions measured on AES fields. The most illuminated conventional field margins were only just as bright as the darkest AES fields. A considerable part of 
the differences in TPAR between conventional and AES field margins can be explained by differences in crop cover (50\%). These differences in crop cover are thought to be driven by several interacting factors related to field management and environmental conditions. This supports the results of Kleijn and van der Voort (1997) who showed that fertilisation of crops synchronously increased biomass production and lowered light penetration, thereby reducing plant growth and species richness at the level of single species and at the level of weed communities. The absence of fertilization on AES fields reduces the productivity of the sites, but this effect interacts with site-specific soil conditions. The AES fields of our study were typically located on less productive soils within the landscape (mostly upslope of adjacent conventionally managed fields) as these are the only locations where rare arable species persist until today. Site conditions were, however, diverse. The AES fields contained both the fields with lowest and those with highest weed cover (range: 9-100\%) of this study. The missing application of herbicides releases arable non-crop plants from chemical stress and increases the competition between crops and weeds on AES fields as compared to conventional field margins. In combination with the only moderate to low productivity of the sites, this resulted in either a sparse or a dense and species-rich weed cover with co-existence of different growth forms. All AES fields were found to offer diverse light conditions in the upper range of the spectrum (35-94\%). Fertilizer input and herbicide application on conventional field margins, typically in combination with more fertile soils, increase the competitive strength of the crop, lead to a denser crop canopy and reduce light transmission.

\subsubsection{The influence of TPAR on the diversity of weed assemblages}

The main determinants of weed species richness in the 50 investigated conventional and AES fields were TPAR and management intensity. Both factors are highly interacting, because high PAR transmissivity was only found on AES fields. AES management also increased weed cover, but the difference to conventional fields was significant only in the field interior and not at the field margin. We explain this surprising result by the fact that some margins of AES fields are located on particularly nutrient-poor and often relatively dry soils supporting only sparse vegetation cover. Correspondingly, TPAR did not explain weed cover at the field margin suggesting stronger growth limitation by nutrient and water shortage than by low light on the less productive AES fields (Kleijn and van der Voort, 1997). Belowground constraints of productivity are thought to be the main drivers of weed species richness in extensively managed herbicide-free arable fields, because they reduce the competitive ability of the crop (Jørnsgård et al., 1996) and of certain competitive N-demanding weeds.

Both weed cover (median <1\%) and species richness (on average $<5$ species per $100 \mathrm{~m}^{2}$ ) were extremely low in the interior of conventional fields, which compares well with surveys by Meyer et al. (2013) in Central and Northern Germany. The species richness and cover of these impoverished weed assemblages seem to be primarily under the control of chemical and mechanical weed management 
(Marshall et al., 2001), since we found no effect of TPAR, region or crop type in the interior of conventional fields.

The influence of light availability on species richness was larger at the field margins, where it was the only influential factor. Species richness was found to be significantly correlated to light availability, but the relatively low correlation coefficient of 0.3 indicates that factors other than light influence species richness on field margins as well. Our results show that these other factors do not co-vary with the kind of crop cultivated on the respective field margin. Regional (i.e. macroclimatic) effects can also be excluded as drivers of species richness on conventional field margins, as we found no significant effect in the regression analyses. It appears that reduced herbicide loads, i.e. the partial release from chemical stress, are mostly responsible for the stronger influence of TPAR on species richness at the margins.

The high variability of light conditions at conventional field margins was found to go along with a high variability in species richness. Species numbers found on the most species-rich conventional field margins were comparable to species numbers in the interior of relatively species-poor AES fields. Field margins are among the last remaining strongholds of arable plant diversity in modern farmland because management intensity is lower and light transmission higher than in the field interior (Fried et al., 2009; Marshall and Moonen, 2002). However, intensification has greatly reduced the diversity of weed communities at the margins as well (Leuschner et al., 2013; Meyer et al., 2013; Storkey et al., 2012), and the ongoing increase in mean field size has dwarfed the fraction of a field being allotted to the field margin. Our results indicate that increasing the light availability on conventional field margins through reduced fertilization and thus lowered crop cover represents a promising measure of improving the habitat quality for arable plants in agricultural landscapes.

None of the four tested crops can be recommended as particularly suitable for enhancing light availability and species richness at conventional field margins. Compared to the other three investigated crops, maize fields were the darkest, but this gradient was not reflected in a significant difference in species richness between maize field margins (on average 13 species per plot) and margins of the other three crops (14-15 species per plot). Contrary to species richness, the community composition of conventional field margins was not influenced by TPAR, but showed a significant influence of crop type with different crops being preferred by different sets of weed species. We found a set of species, such as Echinochloa crus-galli and Solanum nigrum, which preferred maize fields over the other three crops, and a set of species apparently preferring oilseed rape, barley and wheat over maize (e.g. Matricaria recutita, Papaver rhoeas). Differences in the life cycle of these weed species suggest that their occurrence is promoted or inhibited by the specific phenology of the crop and the timing of herbicide treatments and ploughing, while differences in the light regime at maximum crop cover are of secondary importance. Oilseed rape, winter barley and winter wheat are 
sown in autumn and maize as a thermophilous species in late spring. Weed species preferentially associated with maize germinate late in spring, when the effect of herbicides applied to the young maize plants has vanished. Several of them are C4-grasses with elevated temperature optimum, which are unable to withstand the Central European winter as juvenile plants. In contrast, the weeds found preferentially with winter-sown wheat, barley and oilseed rape are all facultative winter annuals which obligatorily germinate in autumn or early in spring (Krumbiegel, 2002; Trefflich et al., 2002). Thus, one way to promote the phytodiversity of arable land is the combination of crops with different phenologies.

\subsection{Conclusions}

The key constraints for diverse weed communities in modern cropping systems are the very effective weed management and the high fertilizer inputs, amplified through dense crop cover and related low light transmissivity to the ground. Our results demonstrate that conventionally managed energy crops (maize, oilseed rape) and conventionally managed winter cereals (wheat, barley) do not systematically differ in terms of weed cover and species richness, even though maize fields were darker than cereal fields in our study regions. Increasing first-generation energy crop cultivation will therefore not necessarily reduce species richness in agricultural landscapes, as long as it does not replace species-rich extensively managed arable fields, fallow land, pastures or meadows. A balanced mix of winter-sown crops (e.g. winter cereals, oilseed rape) and summer-sown crops (e.g. maize) should have a positive influence on the size of the regional arable species pool by creating habitats for species with different phenologies and radiation requirements. However, increasing the diversity of intensively managed crops in the farmland does not solve the agrobiodiversity crisis and it does not generate habitats for the large number of endangered weed species.

Our results do not support claims about a positive synergy between bioenergy production and biodiversity conservation, and concerns about negative biodiversity implications of energy cropping with first-generation energy crops could not be refuted. In modern farmland, an inevitable trade-off exists between maximizing biomass yields and sustaining biodiversity (Gabriel et al., 2013), no matter what kind of crop (food, fodder or bioenergy) is produced. Our results show convincingly that a diverse arable flora is dependent on sites with low to medium nutrient availability, reduced crop cover and corresponding higher light availability and the absence of herbicide application. In order to comply with international and national biodiversity targets, an expansion of these kinds of arable habitats remains crucial. EU and German energy policy has created economic circumstances which strongly favour the intensification of land use practices. Attempts to protect species-rich farmland habitats as part of a diverse cultural landscape suffer from disproportionate disadvantages. The EU setaside scheme which had a strong positive impact on farmland biodiversity has been abolished in 2007 
to meet the demand for land for energy cropping. The amount of grassland in Germany declined by 5\% (250,000 ha) between 2003 and 2012 (Behm, 2012), largely due to conversion to arable land (Nitsch et al., 2012). The bioenergy boost's most deleterious effect on biodiversity is related to its high demand for land which threatens the last strongholds of agrobiodiversity. In the meantime, prices for arable land keep soaring (Emman et al., 2011), and agri-environmental schemes, which compensate farmers for managing arable land extensively, suffer from financial unattractiveness. Legal measures, such as a reform of the EU Common Agricultural Policy (CAP) in the direction of a stronger support of farmers who maintain biodiversity (Oppermann et al., 2012), and the establishment of networks of agrobiodiversity sanctuaries with biodiversity-friendly extensive cropping, are urgently needed.

\subsection{Acknowledgements}

This study was funded by the German Federal Ministry of Education and Research (BMBF) and is part of the BEST Research Framework at the University of Göttingen (http://www.bestforschung.de). We are grateful to Caroline Focke for her dedicated help with the field work and to the project "100 fields for biodiversity" (DBU 24844/02) for funding her. 


\subsection{References}

Ballaré, C. L., Casal, J. J (2000) Light signals perceived by crop and weed plants. Field Crops Research, 67, 149-160.

Bates, D. (2013) Package 'Ime4' - Linear mixed-effects models using S4 classes. http://cran.rproject.org/web/packages/lme4/lme4.pdf (accessed: 30/07/2013).

Behm, C. (2012) Grünland-Erhaltungsverordnungen wirken. http://www.vhoe.de/ fileadmin/PDF/Biodiversitaet/2012-11-30_PM_Entwicklung_beim_Gruenland_2012_pdf.PDF (accessed 29/03/2014).

Biggs, W. W., Edison, A. R., Eastin, J. D., Brown, K. W., Maranville, J. W., Clegg, M. D. (1971) Photosynthesis light sensor and meter. Ecology, 52, 125-131.

BMU, BMELV (2010) National Biomass Action Plan for Germany. Berlin. http://www.bmelv.de/SharedDocs/Downloads/EN/Publications/BiomassActionPlan.pdf?__blob=pu blicationFile (accessed: 09/12/2013).

Bornkamm, R. (1961) Zur Lichtkonkurrenz von Ackerunkräutern. Flora, 151, 126-143.

Britz, W., Delzeit, R. (2013) The impact of German biogas production on European and global agricultural markets, land use and the environment. Energy Policy, 62, 1268-1275.

Buttler, K. P., Thieme, M. and co-workers (2013) Florenliste von Deutschland - Gefäßpflanzen, version 5. http://www.kp-buttler.de (accessed 12/09/2013).

Charles, C., Gerasimchuk, I., Bridle, R., Moerenhout, T., Asmelash, E., Laan, T. (2013) Biofuels - At what cost? International Institute for Sustainable Development, Geneva, Switzerland.

Crawley, M. J. (2007) The R Book. John Wiley \& Sons, Ltd, Chichester, England.

Daughtry, C. S. T., Gallo, K. P., Goward, S. N., Prince, S. D., Kustas, W. P. (1992) Spectral estimates of absorbed radiation and phytomass production in corn and soybean canopies. Remote Sensing of Environment, 39, 141-152.

Destatis (2013) Feldfrüchte und Grünland - Ackerland nach Hauptfruchtgruppen und Fruchtarten. https://www.destatis.de/DE/ZahlenFakten/Wirtschaftsbereiche/LandForstwirtschaftFischerei/Feldfr uechteGruenland/Tabellen/AckerlandHauptfruchtgruppenFruchtarten.html (accessed: 17/12/2013).

DWD (2013) Klimadaten - Mittelwerte 30-jähriger Perioden. Deutscher Wetterdienst, http://www.dwd.de (accessed: 25/06/2013).

Ellenberg, H., Leuschner, C. (2010) Vegetation Mitteleuropas mit den Alpen, 6th ed. Eugen Ulmer KG, Stuttgart, Germany.

Emman, C., Plumeyer, C. H., Theuvsen, L. (2011) Anstieg der Pachtpreise: Welche Rolle spielt die Biogasproduktion? Neue Landwirtschaft, Special Issue: Bodenmarkt 2010/2011, 28-32.

Fitter, A. H., Ashmore, C. J. (1974) Response of two Veronica species to a simulated woodland light climate. New Phytologist, 73, 997-1001.

FNR (2013a) Cultivation of renewable resources in Germany. http://mediathek.fnr.de/media/downloadable/files/samples/r/l/rl_fnr4_0184_grafik_nawaro_.jpg (accessed: 01/07/2013).

FNR (2013b) Maisanbau in Deutschland. http://mediathek.fnr.de/grafiken/daten-undfakten/anbau/maisanbau-in-deutschland.html (accessed: 01/07/2013).

Fried, G., Petit, S., Dessaint, F., Reboud, X. (2009) Arable weed decline in Northern France: Crop edges as refugia for weed conservation? Biological Conservation, 142, 238-243.

Gabriel, D., Sait, S. M., Kunin, W. E., Benton, T. G. (2013) Food production vs. biodiversity: comparing organic and conventional agriculture. Journal of Applied Ecology, 50, 355-364.

Gallo, K. P., Daughtry, C. S. T., Bauer, M. E. (1985) Spectral estimation of absorbed photosynthetically active radiation in corn canopies. Remote Sensing of Environment, 17, 221-232.

Helms, J., Munzel, U. (2009) The npmc package - Nonparametric multiple comparisons. Version 1.07 [Computer Software]. ftp://ftp.ccu.edu.tw/pub/languages/CRAN/web/packages/npmc/npmc.pdf (accessed: 10/08/2013). 
Hipps, L. E. (1983) Assessing the interception of photosynthetically active radiation in winter wheat. Agricultural Meterology, 28, 253-259.

Holt, J. S. (1995) Plant responses to light: a potential tool for weed management. Weed Science, $\mathbf{4 3 ,}$ 474-482.

IPCC (2011) Summary for policymakers, in: Edenhofer, O., Pichs-Madruga, R., Sokona, Y. et al. (Eds.), IPCC special report on renewable energy sources and climate change mitigation, pp. 3-26. Cambridge University Press, Cambridge, England.

Jordan, N., Vatovec, C. (2004) Agroecological benefits from weeds, in: Inderjit (Ed.), Weed biology and management, pp. 137-158. Kluwer Academic Publishers, Dordrecht, the Netherlands.

Jørnsgård, B., Rasmussen, K., Hill, J., Christiansen, J. L. (1996) Influence of nitrogen on competition between cereals and their natural weed populations. Weed Research, 36, 461-470.

Khanna, M., Chen, X. (2013) Economic, energy security, and greenhouse gas effects of biofuels: implications for policy. American Journal of Agricultural Economics, 95, 1325-1331.

Kleijn, D., van der Voort, L. A. C. (1997) Conservation headlands for rare arable weeds: the effects of fertilizer application and light penetration on plant growth. Biological Conservation, 81, 57-67.

Kohlbrecher, C., Wesche, K., Hilbig, W., Leuschner, C., Meyer, S. (2012) Veränderungen in der Segetalflora am Kyffhäusergebirge in den letzten 50 Jahren (1961-2011). Landschaftspflege und Naturschutz in Thüringen, 49, 1-9.

Kruk, B., Insausti, P., Razu, A, Benech-Arnold, R. (2006) Light and thermal environments as modified by a wheat crop: effects on weed seed germination. Journal of Applied Ecology, 43, 227-236.

Krumbiegel, A. (2002) Morphologie der vegetativen Organe (außer Blätter), in: Klotz, S., Kühn, I., Durka, W. (Eds.), BIOLFLOR - Eine Datenbank mit biologisch-ökologischen Merkmalen zur Flora von Deutschland, pp. 93-118. Landwirtschaftsverlag GmbH, Münster, Germany.

Lane, D. R., Coffin, D. P., Lauenroth, W. K. (2000) Changes in grassland canopy structure across a precipitation gradient. Journal of Vegetation Science, 11, 359-368.

Legendre, P. (2008) Studying beta diversity: ecological variation partitioning by multiple regression and canonical analysis. Journal of Plant Ecology, 1, 3-8.

Leuschner, C., Wesche, K., Meyer, S., Krause, B., Steffen, K., Becker, T., Culmsee, H. (2013) Veränderungen und Verarmung in der Offenlandvegetation Norddeutschlands seit den 1950er Jahren: Wiederholungsaufnahmen in Äckern, Grünland und Fließgewässern. Berichte der Reinhold-Tüxen-Gesellschaft, 25, 166-182.

Liu, J. G., Mahoney, K. J., Sikkema, P. H., Swanton, C. J. (2009) The importance of light quality in crop-weed competition. Weed Research, 49, 217-224.

Ludwig. G., Schnittler, M. (1996) Rote Liste gefährdeter Pflanzen Deutschlands. Schriftenreihe für Vegetationskunde, 28, Bundesamt für Naturschutz, Bonn, Germany.

Lütke-Entrup, N, Schäfer, B. C. (2011) Lehrbuch des Pflanzenbaues, Band 2: Kulturpflanzen. Verlag Th. Mann, Gelsenkirchen, Germany.

Marshall, E. J. P., Brown, V. K., Boatman, N. D., Lutman, P. J. W., Squire, G. R., Ward, L. K. (2003) The role of weeds in supporting biological diversity within crop fields. Weed Research, 43, 77-89.

Marshall, E. J. P., Moonen, A. C. (2002) Field margins in Northern Europe: their functions and interactions with agriculture. Agriculture, Ecosystems and Environment, 89, 5-21.

Marshall, J., Brown, V., Boatman, N.., Lutman, P., Squire, G. (2001) The impact of herbicides on weed abundance and biodiversity. PN0940. A report for the UK Pesticides Safety Directorate. http://www.scri.ac.uk/scri/file/EPI/ Impact_of_herbicides_on_weed_abundance_and_biodiversity _PN094.pdf (accessed: 17/10/2013).

Meyer, S., Wesche, K., Krause, B., Leuschner, C. (2013) Dramatic losses of specialist arable plants in Central Germany since the 1950s/60s - a cross-regional analysis. Diversity and Distributions, 19, 1175-1187.

Meynen, E., Schmithüsen, J. (1953-1962) Handbuch der naturräumlichen Gliederung Deutschlands. Selbstverlag der Bundesanstalt für Landeskunde, Remagen, Germany. 
Nitsch, H., Osterburg, B., Roggendorf, W., Laggner, B. (2012) Cross compliance and the protection of grassland - Illustrative analyses of land use transitions between permanent grassland and arable land in German regions. Land Use Policy, 29, 440-448.

Oksanen, J., Blanchet, F. G., Kindt, R. et al. (2011) Package 'vegan' - Community ecology package. Version 1.17.9 [Computer Software]. http://cc.oulu.fi/ jarioksa/softhelp/vegan.html (accessed: 10/08/2013).

Olsen, J., Kristensen, L., Weiner, J., Griepentrog, H. W. (2005) Increased density and spatial uniformity increase weed suppression by spring wheat. Weed Research, 45, 316-321.

Oppermann, R., Gelhausen, J., Matzdorf, B., Reutter, M., Luick, R., Stein, S. (2012) Common Agricultural Policy from 2014 - Perspectives for more Biodiversity and Environmental Benefits of Farming? IFAB, Mannheim, Germany.

Parish, D. M. B., Hawes, C., Hoad, S. P., Iannetta, P. P. M., Squire, G. R. (2009) The contribution of arable weeds to biodiversity, in: Kingely, R.V. (Ed.), Weeds: management, economic impacts and biology, pp. 61-76. Nova Science Publishers, Inc, Hauppage, New York.

Rademacher, B. (1939) Über den Lichteinfall bei Wintergetreide und Winterölfrüchten und seine Bedeutung für die Verunkrautung. Pflanzenbau, 15, 241-265.

Rademacher, B. (1950) Über die Lichtverhältnisse in Kulturpflanzenbeständen, insbesondere in Hinblick auf den Unkrautwuchs. Zeitschrift für Acker- und Pflanzenbau, 92, 129-165.

R Development Core Team (2010) $R$ : A language and environment for statistical computing. $\mathrm{R}$ Foundation for Statistical Computing, Vienna, Austria [Computer Software]. http://www.rproject.org/.

Searle, S.R., Casella, G., McCulloch, C. E. (2006) Variance Components. John Wiley \& Sons, Inc., Hoboken, New Jersey.

Smart, S. M., Thompson, K., Marrs, R. H., Le Duc, M. G., Maskell, L. C., Firbank, L. G. (2006) Biotic homogenization and changes in species diversity across human-modified ecosystems. Proceedings of the Royal Society B: Biological Sciences, 273, 2659-2665.

Sparkes, D. L., Jaggard, K. W., Ramsden, S. J., Scott, R. K. (1998) The effect of field margins on the yield of sugar beet and cereal crops. Annals of Applied Biology, 132, 129-142.

Steinmann, H. H., Dobers, E. S. (2013) Spatio-temporal analysis of crop rotations and crop sequence patterns in Northern Germany: potential implications on plant health and crop protection. Journal of Plant Diseases and Protection, 120, 85-94.

Storkey, J., Meyer, S., Still, K. S., Leuschner, C. (2012) The impact of agricultural intensification and land-use change on the European arable flora. Proceedings of the Royal Society B: Biological Sciences, 279, 1421-1429.

Sutcliffe, O. L., Kay, Q. O. N. (2000) Changes in the arable flora of central southern England since the 1960s. Biological Conservation, 93, 1-8.

Tappeiner, U., Cernusca, A. (1989) Canopy structure and light climate of different Alpine plant communities: analysis by means of a model. Theoretical and Applied Climatology, 40, 81-92.

Trefflich, A., Klotz, S., Kühn, I. (2002) Blühphänologie, in: Klotz, S., Kühn, I., Durka, W. (Eds.), BIOLFLOR - Eine Datenbank mit biologisch-ökologischen Merkmalen zur Flora von Deutschland, pp. 127-131. Landwirtschaftsverlag GmbH, Münster, Germany.

van Elsen, T. (1994) Die Fluktuation von Ackerwildkraut-Gesellschaften und ihre Beeinflussung durch Fruchtfolge und Bodenbearbeitungs-Zeitpunkt. Ökologie und Umweltsicherung, 9, Universität Gesamthochschule Kassel, Kassel, Germany.

Wilmanns, O. (1998) Ökologische Pflanzensoziologie - Eine Einführung in die Vegetation Mitteleuropas, 6th ed. Quelle and Meyer, Wiesbaden, Germany.

Wilson, P. J., Aebischer, N. J. (1995) The distribution of dicotyledonous arable weeds in relation to distance from the field edge. Journal of Applied Ecology, 32, 295-310. 


\title{
Chapter 4
}

\section{Seifert, C., Leuschner, C., Culmsee, H. (2015) \\ Short rotation coppices as habitat for vascular plants}

\author{
Butler Manning, D.; Bemmann, A., Bredemeier, M., Lamersdorf, N.; \\ Ammer, C. (eds.): Bioenergy from dendromass for the sustainable \\ development of rural areas. pp. 63-78, Wiley-Verlag, Weinheim.
}

\subsection{Introduction}

The idea to produce wood chips from fast-growing trees cultivated in the form of short rotation coppice (SRC) on arable land arose from the need to find sustainable solutions to meet the increasing demand for wood products and energy while at the same time reducing green-house gas emissions and halting the overexploitation of forests (Caslin et al., 2010). The strong increase in the global demand for wood chips during the last decade has been driven by current policy frameworks targeting the reduction of greenhouse gas emissions and the diversification of the energy supply. Between 2000 and 2010, the global net solid biofuel trade increased sixfold, from 3.5 to 18 million $\mathrm{t} \mathrm{a}^{-1}$ (Lamers et al., 2012). Europe is the most important player on the global wood chip market, covering about two thirds of the global net solid biofuel trade in 2010 (Lamers et al., 2012). Sustainable wood production not only implies maintaining soil fertility and avoiding $\mathrm{N}_{2} \mathrm{O}$ emissions but also preserving biodiversity. The impact of SRC on biodiversity has been an important research focus in recent years (Rowe et al., 2009; Dauber et al., 2010). The effects on biodiversity will differ with the regional setting in which SRC is cultivated. In regions such as western and central Europe, where the most dramatic decline in species richness in the last decades has occurred on farmland rather than in forests (Wesche et al., 2012; Meyer et al., 2013), the type of farming system substituted by SRC will influence the impact on biodiversity most strongly, the effect depending on whether the previous land use was more or less beneficial for biodiversity than SRC (Rowe et al., 2009). Once established, plant community composition in SRC is affected by the soil and climate conditions, the land use history and the surrounding landscape (Baum et al., 2012b, Simmering et al., 2013).

Within the framework of the BEST research project, the effects of SRC on plant diversity were investigated in two study regions in central Germany. The aim of the study was to characterise SRC as 
habitat for vascular plants and to evaluate its potential contribution to the conservation of plant species diversity in European cultural landscapes. Data from vegetation surveys, analyses of soil parameters and measurements of the light regime in the SRC stands studied were compared with literature data from alternative land use types, such as arable land, grassland and forest. More specifically, the following research questions were addressed:

How do habitat conditions and the associated plant communities in SRC change with time since planting?

How do habitat conditions prevailing in SRC during the different growth stages of the first rotation compare with habitat conditions associated with other types of land use?

What are the implications of these findings for the conservation of vascular plant species diversity?

How can SRC be managed to maximise positive effects on vascular plant diversity?

\subsection{Methods}

\subsubsection{Study sites}

The study was carried out in 10 SRC plantations of different ages located in two study regions in central Germany (Niedersächsisches Hügelland and Thüringer Becken) and planted with either poplar (variety Max 1; Populus maximowiczii $\times$ P. nigra) or willow (variety Tordis; (Salix schwerinii $\mathrm{x}$ S. viminalis) $\times$ S. viminalis) (Table 4.1). Six plantations were newly established on arable land in early spring 2011 at three different sites. Four older plantations established in 2005, 2007 and 2008 were also surveyed. As no older plantations existed in the Niedersächsisches Hügelland, only newly established plantations were surveyed in this region. The landscape context, climate and soil conditions were similar for all sites within each region but differed considerably between the two study regions. The climate of the Niedersächsisches Hügelland was more oceanic than that of the Thüringer Becken (mean annual precipitation of 650 and $500-550 \mathrm{~mm}$, respectively; mean annual temperature of 8.7 and $9.2^{\circ} \mathrm{C}$, respectively), and the agricultural landscape was characterised by smaller fields and a higher diversity of landscape elements such as field margins and hedges. The soils in the hill landscape of the Niedersächsisches Hügelland were also less loamy and had a lower $\mathrm{pH}$ than in the Thüringer Becken.

All of the SRCs in the Thüringer Becken (see Table 4.1) were established on former arable land, which had been used to produce crops using conventional farming techniques for at least 100 years. Only at the Dachwig site had the land been left fallow for 2 years before the establishment of the SRC. 
The site at Reiffenhausen was historically arable land, but was not cropped during the 1990s to comply with the European set-aside requirements. On the land now hosting the poplar plantation at that site and on the western half of the willow plantation, crop production was resumed in 2009. The eastern part of the willow plantation remained fallow until the SRC was established in 2011.

Table 4.1 Characteristics of the SRC plantations studied.

\begin{tabular}{|c|c|c|c|c|c|c|c|}
\hline ID & Site & $\begin{array}{l}\text { Tree } \\
\text { genus }\end{array}$ & $\begin{array}{l}\text { Year of } \\
\text { plantin } \\
\mathrm{g}\end{array}$ & $\begin{array}{l}\text { Nearest } \\
\text { village }\end{array}$ & $\begin{array}{l}\text { Study } \\
\text { region }\end{array}$ & $\begin{array}{l}\text { Area } \\
\text { (ha) }\end{array}$ & $\begin{array}{l}\text { Row } \\
\text { spacing } \\
(\mathbf{m})^{\text {a) }}\end{array}$ \\
\hline \multirow[b]{2}{*}{ B1 } & BERTA I & Poplar & 2011 & \multirow{2}{*}{ Großfahner } & & 0.3 & $0.75 / 1.50$ \\
\hline & (new) & Willow & 2011 & & Thuringian & 0.3 & $0.75 / 1.50$ \\
\hline \multirow{2}{*}{ B2 } & REDT A U & Poplar & 2011 & \multirow{2}{*}{ Döllstädt } & Basin & 0.5 & $0.75 / 1.50$ \\
\hline & BEKI A II & Willow & 2011 & & & 0.5 & $0.75 / 1.50$ \\
\hline \multirow{2}{*}{$\mathrm{R}$} & Reiffen- & Poplar & 2011 & \multirow{2}{*}{$\begin{array}{l}\text { Reiffen- } \\
\text { hausen }\end{array}$} & Lower & 0.5 & $0.75 / 1.50$ \\
\hline & hausen & Willow & 2011 & & Saxon Hills & 0.6 & $0.75 / 1.50$ \\
\hline \multirow{2}{*}{ B1o } & BERTA I & Poplar & 2007 & \multirow{2}{*}{ Großfahner } & & 0.3 & $0.80 / 0.80$ \\
\hline & (old) & Willow & 2005 & & Thuringian & 0.4 & $1.50 / 1.50$ \\
\hline \multirow{2}{*}{ D } & Dachwig & Poplar & 2008 & \multirow{2}{*}{ Dachwig } & Basin & 0.3 & $1.00 / 1.00$ \\
\hline & & Willow & 2008 & & & 0.3 & $0.75 / 2.50$ \\
\hline
\end{tabular}

The landscape surrounding all of the SRCs in the Thüringer Becken was dominated by large-scale arable land use for more than a century. The nearest forest was approximately $2 \mathrm{~km}$ away from the sites B1, B1o and B2 and $3.5 \mathrm{~km}$ from site D (see Table 4.1 for abbreviations). The poplar and willow plantations at Reiffenhausen were adjacent to arable land set aside during the 1990s. To the north and north-east, they bordered the former inner German border, which was characterised by a mosaic of open grassland with solitary trees, hedges and woods. The closest forest was located across the old border in Thüringen, less than $0.5 \mathrm{~km}$ away.

No fertiliser was applied in the SRC studied. Weed management consisted of cutting weeds with a mower between the twin rows at irregular intervals. Herbicide application (Thuringian sites: fluazifopp; Reiffenhausen: diflufenican, flurtamone, flufenacet) took place in April/May 2011. Due to the late application, however, many weeds were already too mature for the herbicides to have an optimal effect. The recommended application periods to maximise weed suppression would have been either just before or directly after germination or, in the case of fluazifop-p, from the time of emergence of the second to the fourth pair of leaves of the targeted weeds.

\subsubsection{Vegetation sampling and analysis}

In each SRC, three plots of $1 \mathrm{~m} \times 25 \mathrm{~m}$ were randomly placed inside the stand, parallel to the planted rows, with a minimum distance of $10 \mathrm{~m}$ between plots. Three more plots of the same size were 
surveyed at the edge of each SRC starting with the first row of planted trees. The cover of all vascular plant species (with the exception of the planted trees) was recorded according to the Braun-Blanquet cover abundance scale in each plot (Wilmanns, 1998). The surveys within all of the SRCs took place (i) in June/July 2011, (ii) in April 2012 and (iii) in June/July 2012. The surveys at the edges took place during the latter two periods. The Dachwig SRC was only surveyed in July 2012, and only the interior of the stands was considered.

The vegetation data were analysed with respect to habitat preference, naturalisation status and red list status of the species. The records from all three plots per SRC were pooled. The species numbers mentioned in this paper always refer, therefore, to a plot size of $75 \mathrm{~m}^{2}$. The habitat preference of a species was assigned based on the main occurrence of the species in a vegetation formation (Hauptvorkommen) according to FloraWeb (BfN, 2014). Species not clearly assignable to one habitat type were classified as habitat generalists. Data about the naturalisation status were obtained from the BiolFlor database (BfN, 2002). Native species were distinguished from archaeophytes (naturalised prior to $1492 \mathrm{AD}$ ) and neophytes (naturalised after $1492 \mathrm{AD}$ ). The red list status was obtained from Ludwig and Schnittler (1996).

\subsubsection{Soil sampling and analyses}

Soil samples were taken at four random locations within each vegetation sampling plot (with the exception of the Dachwig SRC) from the uppermost $10 \mathrm{~cm}$ of the soil column with a soil core of 5.1 $\mathrm{cm}$ diameter in summer 2011. The four samples per plot were thoroughly mixed and stored at $4{ }^{\circ} \mathrm{C}$. The $\mathrm{pH}$ of the fresh soil was measured with a $\mathrm{pH}$ meter in $\mathrm{H}_{2} \mathrm{O}$ in accordance with HFA (2005). The base saturation ( $\left[\mathrm{Ca}^{2+}, \mathrm{Mg}^{2+}, \mathrm{K}^{+}\right] /\left[\mathrm{Ca}^{2+}, \mathrm{Mg}^{2+}, \mathrm{K}^{+}, \mathrm{Al}^{3+}, \mathrm{Mn}^{2+}, \mathrm{Fe}^{2+}, \mathrm{H}^{+}\right]$, in \%) was calculated from an analysis of the effective cation-exchange capacity via percolation with $\mathrm{BaCl}_{2}$ solution $(0.2 \mathrm{~N})$ based on methods described in HFA (2005). The plant-available phosphorus was extracted with anion-exchange resin bags (Sibbesen, 1977). The total amount of carbon $\left(\mathrm{C}_{\mathrm{tot}}\right)$ and nitrogen $\left(\mathrm{N}_{\mathrm{tot}}\right)$ and the $\mathrm{C} / \mathrm{N}$-ratio for each sample were determined with a C/N-elemental analyser (Vario EL III, Elementar, Hanau, Germany). To determine the amount of organic carbon $\left(\mathrm{C}_{\text {org }}\right)$, samples were heated to $450^{\circ} \mathrm{C}$. In the process, all of the organic carbon was burned away, and the quantity of the remaining inorganic carbon was measured and subtracted from the total carbon $\left(\mathrm{C}_{\mathrm{tot}}\right)$. An estimate of the soil organic matter content (in \%) was obtained by multiplying $\mathrm{C}_{\text {org }}$ with the factor 1.72 .

\subsubsection{Measurements of PAR-transmission}

Quantum sensors (LI-190 Quantum Sensor, LI-COR, Lincoln, Nebraska, United States) were used to measure the flux density of photosynthetically active radiation (PAR, expressed as $\mu \mathrm{mol}$ photons $\mathrm{m}^{-2} \mathrm{~s}^{-1}$ ) above and below the tree canopy around noon (10 a.m. to 3 p.m.) on days with 
uniformly overcast sky. One PAR sensor was positioned at ground level, approximately $15 \mathrm{~cm}$ above the soil surface, in order to record the light climate experienced by herbaceous plants in SRC (transmitted PAR; PAR trans). A second PAR sensor was placed approximately $1 \mathrm{~m}$ above the tree canopy (in the case of young stands) or in the open about 30-50 m south of the SRC (older stands) to measure incident PAR flux density $\left(\mathrm{PAR}_{\text {inc }}\right)$. In each $\mathrm{SRC}, 10$ measuring points were randomly selected and 5 consecutive light measurements taken at time intervals of approximately $5 \mathrm{~s}$ at each point. With the help of a $100 \mathrm{~m}$ cable, $\mathrm{PAR}_{\text {trans }}$ and $\mathrm{PAR}_{\text {inc }}$ were recorded synchronously with a LICOR LI-1400 data logger. PAR transmissivity (TPAR, in \%) was calculated as

$$
\mathrm{TPAR}=\left(\mathrm{PAR}_{\text {trans }} / \mathrm{PAR}_{\text {inc }}\right) \times 100(\text { eq. } 4.1)
$$

The mean TPAR per SRC was obtained by averaging over the five consecutive measurements per point and subsequently calculating the mean across the 10 points per SRC.

\subsection{Results and Discussion}

\subsubsection{Habitat conditions and plant diversity in newly established short rotation coppices}

Habitat conditions in the first and second year SRC were similar to habitat conditions on cropland left fallow. In July of the year of planting of the cuttings, the total tree cover in the SRC stands was about $1 \%$ and the mean PAR transmittance was 89\% (Fig. 4.1), creating optimal conditions for pioneer vegetation. On fertile soils, canopy closure may be achieved in SRC in the second year after planting, if weather conditions are favourable (Tubby and Armstrong, 2002). In this study, this was far from being the case, even on the loess sites. The tree cover was still relatively low in the second summer $(<18 \%)$, but PAR transmittance decreased to $66 \%$. As was mentioned in section 4.2.1, weed management in the newly established SRCs did not follow standard agricultural techniques (cf. Tubby and Armstrong, 2002; Caslin et al., 2010). The sites were not prepared with glyphosate in either autumn or spring before planting, and the application of herbicides was too late to substantially affect many weeds. Strong weed growth in combination with an exceptionally dry spring season in 2011 retarded the growth of both poplars and willows. If SRC is to be cultivated at a larger scale, farmers will in all likelihood need to follow SRC establishment guidelines to keep young crops weed free (Tubby and Armstrong, 2002; Caslin et al., 2010). This will inevitably decrease considerably the value of SRC as habitat for vascular plant species during the first years after planting (Gustafsson, 1987; Cunningham et al., 2004). 


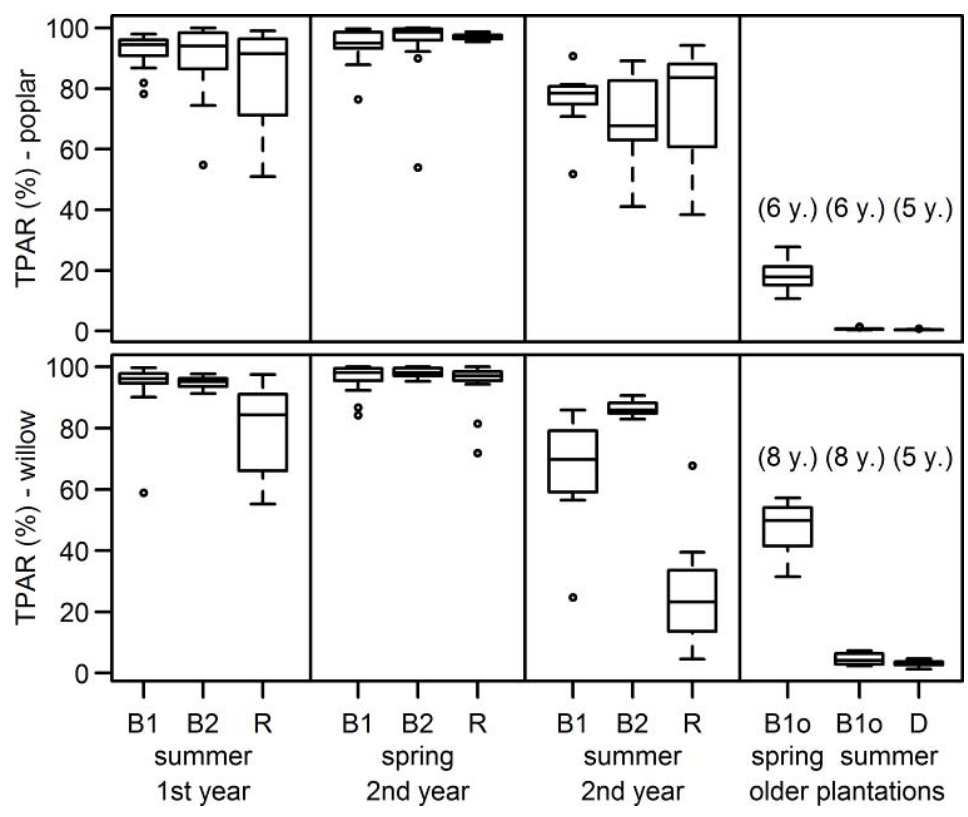

Fig. 4.1 PAR transmittance (TPAR, in \%) in poplar and willow SRC in central Germany. See Table 4.1 for site descriptions (abbreviations).

The narrow C/N-ratio and the low soil organic matter content (Table 4.2) in the SRCs also resembled conditions on arable land (C. Seifert, C. Leuschner \& H. Culmsee, unpublished data). The C/N-ratio was lower than values measured in older SRC in northern Germany and Sweden (Baum et al., 2012b). The availability of phosphorus for plants was within the lower range of values usually found on arable fields in the study regions (C. Seifert, C. Leuschner \& H. Culmsee, unpublished data), as no P fertilisation took place in the plantations.

Table 4.2 Soil chemical properties of SRC in central Germany.

\begin{tabular}{lllllll}
\hline \multirow{2}{*}{ Site } & $\begin{array}{l}\text { Tree } \\
\text { species }\end{array}$ & $\mathbf{p H}$ & $\begin{array}{l}\text { Base } \\
\text { saturation } \\
(\boldsymbol{\%})\end{array}$ & $\begin{array}{l}\text { Plant- } \\
\text { available } \\
(\boldsymbol{\mu m o l} / \mathbf{g D W})\end{array}$ & $\begin{array}{l}\mathbf{P} \text { C/N-ratio } \\
(\mathbf{g} / \mathbf{g})\end{array}$ & $\begin{array}{l}\text { Soil } \\
\text { organic } \\
\text { matter }(\%)\end{array}$ \\
\hline \multirow{2}{*}{ BERTA I } & Poplar & $7.5 \pm 0.1$ & $99.95 \pm 0.04$ & $0.7 \pm 0.1$ & $8.64 \pm 0.38$ & $2.95 \pm 0.16$ \\
& Willow & $7.6 \pm 0.1$ & $99.97 \pm 0.03$ & $0.7 \pm 0.1$ & $8.44 \pm 0.34$ & $2.91 \pm 0.11$ \\
BERTA II & Poplar & $7.4 \pm 0.2$ & $99.93 \pm 0.03$ & $0.7 \pm 0.1$ & $8.83 \pm 0.03$ & $2.85 \pm 0.07$ \\
& Willow & $7.5 \pm 0.2$ & $99.99 \pm 0.00$ & $0.6 \pm 0.1$ & $8.93 \pm 0.32$ & $3.00 \pm 0.17$ \\
Reiffenhausen & Poplar & $5.3 \pm 0.1$ & $99.78 \pm 0.05$ & $1.8 \pm 0.2$ & $9.90 \pm 0.16$ & $2.01 \pm 0.04$ \\
& Willow & $5.3 \pm 0.2$ & $98.97 \pm 0.46$ & $2.0 \pm 0.2$ & $9.25 \pm 0.24$ & $2.78 \pm 0.09$ \\
\hline BERTA I & Poplar & $7.5 \pm 0.1$ & $99.80 \pm 0.12$ & $0.8 \pm 0.1$ & $7.40 \pm 0.28$ & $2.82 \pm 0.06$ \\
(old stands) & Willow & $7.4 \pm 0.1$ & $99.98 \pm 0.02$ & $1.2 \pm 0.1$ & $9.06 \pm 0.10$ & $3.90 \pm 0.07$ \\
\hline
\end{tabular}

Values are the mean $( \pm \mathrm{SE})$ of three samples per SRC. DW: dry weight. The first three sites refer to 1-year-old SRC.

Plant species richness and community composition were found to differ strongly between SRCs of different age classes (Fig. 4.2). The plant communities and the succession patterns found in the newly 
established SRC were typical of first- and second-year fallows (Steffan-Dewenter and Tscharntke, 1997; Tscharntke et al., 2011). On average, 25 species were recorded per $75 \mathrm{~m}^{2}$ in the poplar and 28 species in the willow plantations (appendix 4.A). More than $80 \%$ were annuals associated with arable land, probably mostly emerging from the seed bank. The remaining $20 \%$ were species associated with nitrophilous herbaceous vegetation or habitat generalists. The average species richness increased to 38 species in the poplar and 33 species in the willow plantations in the second year. This result is in accordance with earlier studies reviewed by Baum et al. (2009), who found species numbers, and the number of annual species, to increase during the first 2 years and to decrease thereafter with increasing closure of the tree canopy. The additional species found during the second year were mainly perennial species associated with nitrophilous herbaceous vegetation, grassland or forest (saplings of woody species, no forest herbs), or perennial habitat generalists (Fig. 4.2, cf. Fry and Slater, 2009). The number of indigenous species also increased remarkably from the first to the second year (Fig. 4.3). By contrast, the number of archaeophytes remained stable or decreased slightly. No species red listed for Germany were found in the SRC. Several other studies of SRC in the Netherlands, Germany and Sweden also recorded no or only few rare or red listed species (Vonk, 2008; Baum et al., 2012b). In clear contrast, to this, however, Delarze and Ciardo (2002) found 18 red list species in a newly established SRC in Switzerland.

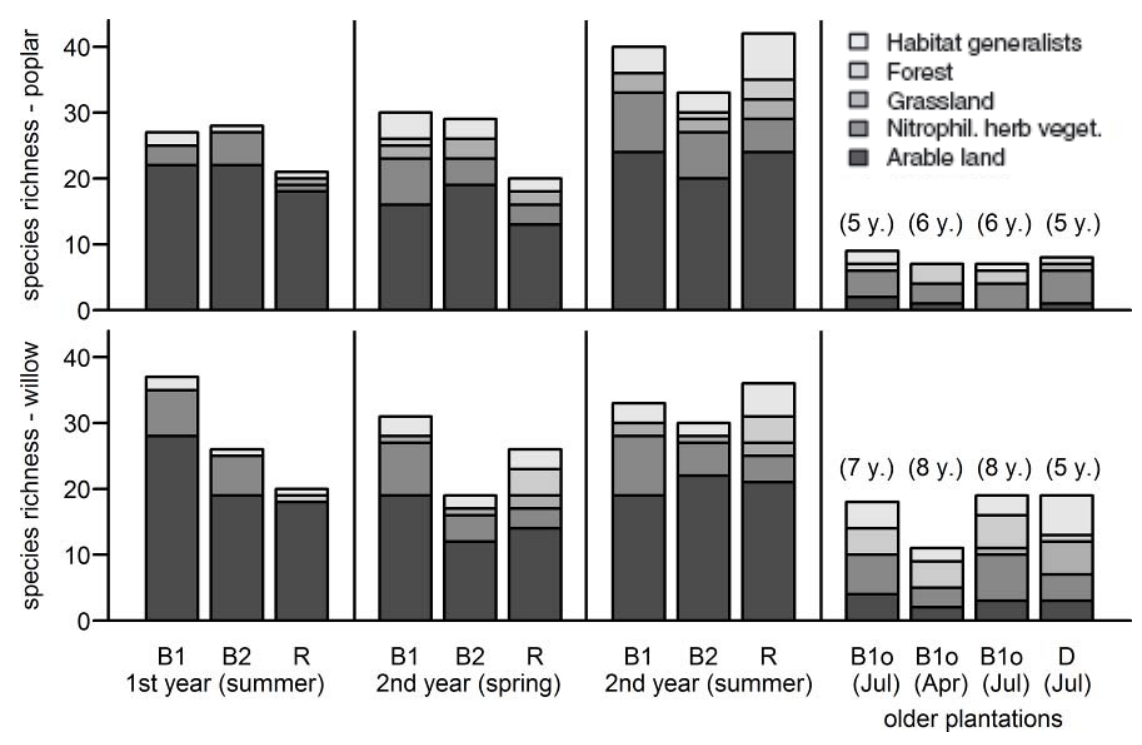

Fig. 4.2 Number of vascular plant species found in SRC in central Germany by habitat preference of the species. For site descriptions (abbreviations), see Table 4.1. The area sampled per SRC was $75 \mathrm{~m}^{2}$.

These general trends were consistent across all three sites with newly established SRC, for both poplar and willow stands, although the soil analyses indicated differences in site conditions between the plantations in the Thüringer Becken and those in the Niedersächsisches Hügelland (Table 4.2). The 
Reiffenhausen SRC was situated on middle Buntsandstein sediments, whereas the SRC in Thüringen were planted at sites on Pleistocene loess deposits. The soil of the Reiffenhausen SRC was more acidic $(\mathrm{pH}=5.3)$ than in the Thüringer Becken $(\mathrm{pH} \sim 7.5)$. The base saturation was very high in all soils under SRC (> 99\%) and was in the upper range of values measured by Baum et al. (2012b) in SRC on acidic arable soils in northern Germany and Sweden.

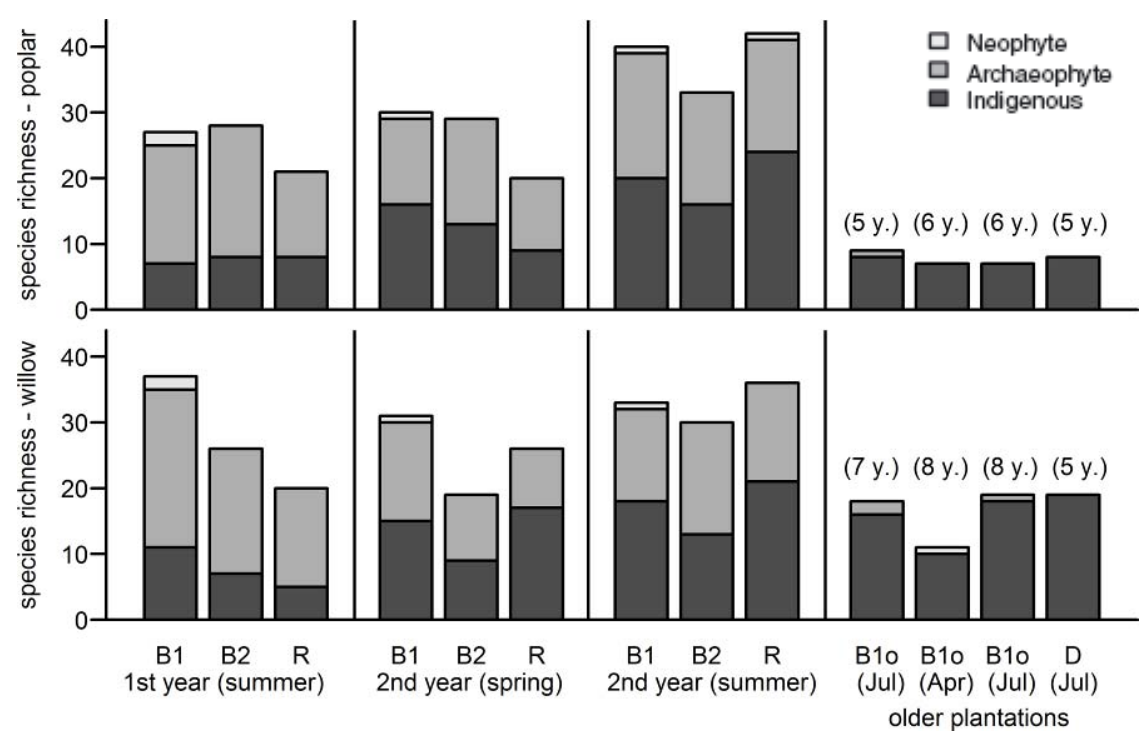

Fig. 4.3 Number of vascular plant species found in SRC in central Germany by naturalisation status. For site descriptions (abbreviations), see Table 4.1. The area sampled area per SRC was $75 \mathrm{~m}^{2}$.

\subsubsection{Habitat conditions and plant diversity in older short rotation coppice}

Species richness in the older SRC with a closed canopy was much lower than in the first- and second-year plantations. In summer, 79 species per $75 \mathrm{~m}^{2}$ were found in the old poplar plantations (PAR transmittance 0.5-0.7\%) and 18-19 species in the old willow SRC (PAR transmittance 3.2-4.6 $\%$; Figures 4.1 and 4.2). The share of annual species associated with arable land decreased to $<20 \%$. The species numbers in the older poplar plantations were within the upper part of the range of values recorded on intensively managed arable land (Meyer et al., 2013; Seifert et al., 2014) and light availability on the ground was lower than in mature spruce forests (Ellenberg and Leuschner, 2010). The total herb cover value in the old poplar plantations did not exceed 5\%, apart from one exception where stinging nettle (Urtica dioica) covered almost $20 \%$ of the sampling plot. The recorded species numbers in the old poplar plantations were found to be considerably lower than numbers recorded by Glaser and Schmidt (2010) who found on average 17 (clone Beaupré, PAR transmittance of 25-35\%, dominance of few highly competitive species) and 27 species $100 \mathrm{~m}^{2}$ (clone Max 1, PAR transmittance of 5-7\%) in two poplar plantations of unknown age, but not recently established, in 
Sachsen. These differences can be explained by the far lower light transmittance in the poplar SRC surveyed as part of this study. The old willow SRC stands had a wider row spacing (Table 4.1) and correspondingly higher PAR transmittance, species richness and understory vegetation cover. Nevertheless, the light availability in the willow SRC was still in the lower range of values measured in mature forests (Ellenberg and Leuschner, 2010) and in maize fields (Seifert et al., 2014). The most dominant species in the willow SRC with cover values of up to $75 \%$ was couch grass (Elymus repens), a noxious weed species feared by farmers. Other important species were stinging nettle (Urtica dioica), hedge bindweed (Calystegia sepium), creeping thistle (Cirsium arvense) and cleavers (Galium aparine), all common generalist weedy species of nitrophilous herbaceous vegetation and arable land. Vegetation records by other authors (Gustafsson, 1987; Britt et al., 2007; Glaser and Schmidt, 2010; Baum et al., 2012b) confirmed the finding that mature SRC is commonly dominated by a small set of generalist perennial herbs with no conservation status. In the older plantations, the importance of archaeophytes of arable habitats decreased drastically as compared to first- or second-year stands (Fig. 4.3). The transition pattern over time, from annual species associated with arable land to perennials associated with various habitat types, including forest species, concurred with findings by other authors and is typical for SRC (Delarze and Ciardo, 2002; Britt et al., 2007; Baum et al., 2012a). Species richness in spring, before the leaf flush, was found to be as low (poplar) or about $40 \%$ lower (willow) than in summer (Fig. 4.2). Contrary to findings by Gustafsson (1987) from older SRC in Sweden, no typical 'spring' species (e.g. forest geophytes or 'early bird' winter annuals) were found, and all species present in spring persisted also during summer. These differences may, however, have been the result of different land use histories and landscape settings between the sites in the two studies.

Habitat conditions in the older SRC were not directly comparable to any other land use type. PAR transmittance in these plantations was drastically reduced and similar to very dense stands of young trees during initial phases of forest regeneration (Dölle and Schmidt, 2009). The C/N-ratio and the soil organic matter content in the upper mineral soil layer (Table 4.2) were similar to the values measured on arable fields (compare chapter 2) and narrower $(\mathrm{C} / \mathrm{N})$ and lower (organic matter) than characteristic values from forest soils (Ellenberg and Leuschner, 2010; Yang and Luo, 2011). Due to the dense canopy, only few of the species associated with open habitats were able to persist. Herbaceous forest species were not found either (with the exception of wind dispersed milletgrass, Milium effusum), as the respective propagules were not present at the sites due to the long standing agricultural use. Stand age and distance to the next forest are the most important factors determining the potential for forest herbs to colonise new SRC (Verheyen et al., 2003). Colonisation from nearby forests (2.0-3.5 km away) is likely to take much longer than 5-8 years. The timeframe of 20-30 years, which is often cited as the maximum age for SRC (Caslin et al., 2010), might not be enough to allow for the establishment of many herbaceous forest species of high conservation value particularly in agricultural landscapes with little forest cover (Gustafsson, 1987; Hardcastle, 2006). Therefore, and due to the dramatic pace 
of biodiversity loss in agricultural habitats, it seems appropriate to focus on optimising habitat conditions in SRC for species associated with cultural landscapes and farmland habitats, rather than for forest species.

\subsubsection{Implications for plant species conservation}

The data presented in this paper, in conjunction with results from previous studies, indicated that the suitability of SRC as habitat for vascular plant species in agricultural landscapes varies widely with the age of the plantation (cf. Baum et al., 2012b) and with the intensity of SRC management. When assessing whether establishing a SRC will benefit plant diversity, it is essential to consider the type of land use being replaced and the kind of SRC replacing it. Fig. 4.4 represents an attempt to place SRC in the context of other common agricultural land use types with regard to management intensity and its potential contribution to maintaining plant diversity. Low-input, structurally diverse SRC assumes an intermediate position between multispecies hedges and copses and high-input SRC in terms of its ability to support plant diversity. It has the highest potential to be both economically and ecologically viable. Replacing the few remaining areas of agricultural landscape with land use types that support very high plant diversity, such as extensively managed grasslands, croplands and fallows with SRC would decrease plant diversity, whereas planting low-input SRC on intensively managed arable land has the potential to increase the plant diversity of agricultural landscapes. It must be stressed that the management intensity of arable land, grassland and woody landscape elements is

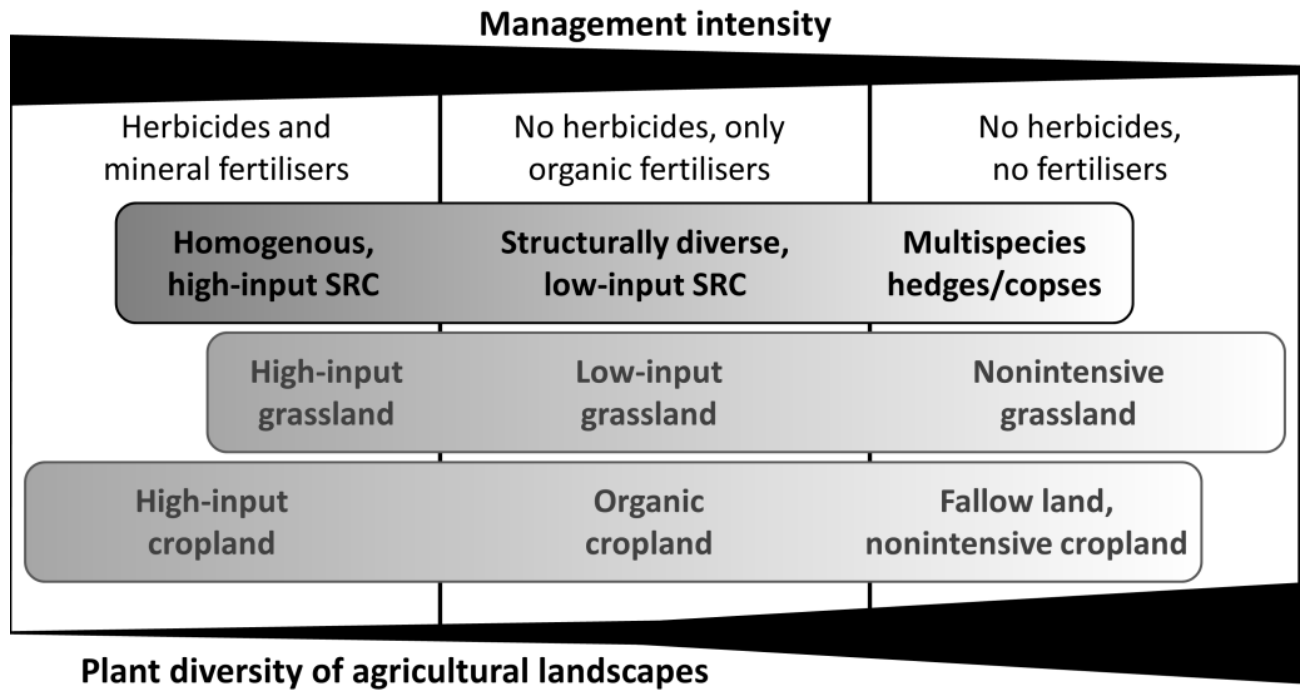

Fig. 4.4 Value of SRC for plant diversity in agricultural landscapes relative to other land use options and management intensity (based on Hoogeveen et al., 2005; Gabriel et al., 2013). Maximum diversity is expected to be achieved where a regionally adapted mosaic of woody landscape elements, grassland and arable land exists. 
a continuum and that effects of reductions in management intensity can vary widely under different environmental conditions. Therefore, Fig.4.4 is necessarily a simplification. Additionally, the target species of conservation efforts, or group of species, must be taken into consideration. Rare arable archaeophytes will not find suitable conditions after canopy closure; these are better served by nonintensive cropping or regularly renewed fallows. In landscapes with few structural elements, where large fields and high-input cropping systems prevail due to the presence of fertile soils, SRC can contribute to maintaining a basic level of plant diversity and serve as refuges and feeding resources for species from higher trophic levels, such as insects and birds. This complexity implies that management decisions aimed at enhancing habitat diversity must always be site specific.

\subsubsection{Management recommendations for the enhancement of plant diversity}

The management of SRC can differ widely from homogenous, high-input plantations to structurally diverse, low-input coppices (Gustafsson, 1987; Cunningham et al., 2004; Baum et al., 2009; Fig. 4.4). In general, from the perspective of plant species conservation, the characterisation 'high input' may still apply at considerably lower fertilisation and herbicide application rates than commonly occur on conventional cropland (cf. Storkey et al., 2012; Gabriel et al., 2013). The SRCs surveyed in this study were situated midway along the continuum between these two extremes, being 'low input' but structurally homogeneous. Factors influencing the value of SRC for plant diversity are (i) the amounts and timing of fertiliser input and herbicide application, (ii) the diversity of tree species and varieties planted, (iii) the temporal and spatial heterogeneity of habitat conditions in SRC (Delarze and Ciardo, 2002; NABU, 2008; Weih, 2008; Glaser and Schmidt, 2010; Baum et al., 2012b) and (iv) the structure and complexity of the surrounding landscape (Baum et al., 2012b). The data presented in this chapter indicated that first- and second-year SRC can be a valuable habitat for farmland plant species, where little or no herbicides and no fertiliser are applied. Cunningham et al. (2004) showed that commercial SRC with higher herbicide and fertiliser inputs has lower vegetation cover and species richness than SRC planted for non-commercial research purposes.

SRC stands with a higher degree of tree variability might habitat con provide more diverse habitat conditions, also for the accompanying flora as tree species, for instance, differ in terms of phenology and leaf area index, support different phytophagous species and produce material with different degrees of decomposability. Planting more than one genotype per SRC is the most basic step towards increasing crop biodiversity and is strongly recommended for phytosanitary reasons (Caslin et al., 2010; Georgi et al., 2013; Georgi and Müller, 2013). Using several species of fast-growing trees and interspersing indigenous trees and shrubs in the SRC can further increase the biodiversity value (NABU, 2008; Unseld et al., 2011). 
In order to maximise the variability of habitat conditions in SRC, four management decisions are of particular importance. Firstly, tree spacing and canopy density influence PAR transmittance and herb diversity (Delarze and Ciardo, 2002). The differences in plant diversity between the older poplar and the willow SRCs presented here were at least partially due to differences in row spacing and light availability in the understory. Irregular spacing and the occasional introduction of canopy openings can further increase habitat diversity. The second important factor is the length of the harvesting cycle (Gustafsson, 1987; Baum et al., 2012b). Short harvesting cycles create open habitat conditions more frequently, increasing plant diversity. Several authors recommended rotation times of three years for willow SRC (Gustafsson, 1987; Caslin et al., 2010). Thirdly, harvesting parts of the plantation in different years increases the diversity of growth stages within the SRC and correspondingly broadens the range of site conditions found in the plantation (Baum et al., 2009). Surveys from traditional German coppice woodlands show that this mosaic of of different growth stages is important to maintain higher degrees of phytodiversity (Conrady, 2007). To our knowledge, no records of plant species diversity directly after harvesting have been published yet. Baum et al. (2012a) showed, however, that species composition varied with the total age of the plantation rather than with the time since the last harvest. Generally, competitive perennial species such as couch grass are likely to have spread by the time of the first harvest (Gustafsson, 1987; Baum et al., 2012a; Baum et al., 2012b) and threaten to suppress less competitive annuals or archaeophytes even after harvest. The

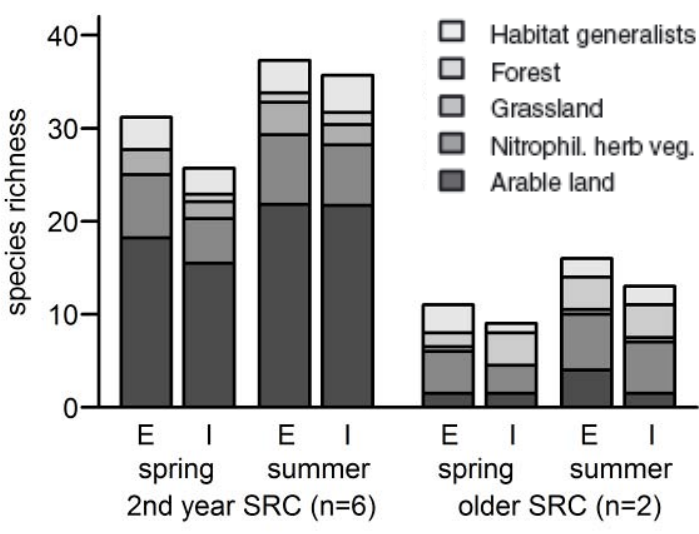

Fig. 4.5 Number of vascular plant species found at the edges (E) and in the interiors (I) of SRC in central Germany by habitat preference of the species. Species numbers per $75 \mathrm{~m}^{2}$ were averaged across all of the studied SRC of an age class, with stands of willow and poplar pooled.

fourth point, which is of particular importance, is the size of the plantation and its edge length (Unseld et al., 2011). The edges of SRC were by $4-19 \%$ richer in species than the corresponding stand interior (Fig. 4.5). The occurrence of plant species of arable land, grasslands and nitrophilous herb vegetation showed a tendency to increase towards the edge, while forest species decreased. This is in accordance 
with the findings by Cunningham et al. (2004), who found species richness to decline from the edge towards the centre of the SRC during the first 2 years after establishment. Smaller SRC with longer edges also contributed more strongly to biodiversity conservation than larger, homogenous plantations in previous studies (Cunningham et al., 2004; NABU, 2008; Weih, 2008; Baum et al., 2009). Agroforestry systems in which SRC strips alternate with grassland or cropland are an interesting option for maximising edge length and they can even increase the revenue per hectare (Unseld et al., 2011; Bärwolff et al., 2011; Bärwolff et al., 2012; Hartmann and Lamersdorf, 2015).

\subsection{Conclusions}

SRC can be either beneficial or detrimental to plant species diversity on the landscape scale, depending on the targeted species, the management intensity of the SRC, the land use type being replaced and the surrounding landscape context (Fig. 4.4). The habitat conditions for vascular plants prevailing in SRC vary extremely quickly, particularly in the early part of each harvesting cycle, making it difficult for habitat specialists to persist (Delarze and Ciardo, 2002). Consequently, older SRC was dominated by a limited set of generalist species, and all of the younger and older SRC stands investigated completely lacked red list plant species. SRC is unlikely to attain the status of habitat of high nature conservation value. The conversion of ecologically valuable habitats, such as permanent grasslands and other man-made European Natura habitat types, to SRC should, therefore, be avoided (BfN, 2010). For economic reasons, it is likely that SRC and other second-generation energy crops, such as Miscanthus (Harvolk et al., 2014), will preferentially be planted on marginal sites and not on very fertile soils where high yields can be obtained with annual crops. This has become even more valid since the onset of the bioenergy boom, with high pressure even on marginal arable lands, where the last strongholds of agro-biodiversity remain. Depending on the previous use of these lands, the conversion of marginal land to SRC will often conflict with biodiversity conservation. However, narrow SRC strips dividing large, uniform arable fields can contribute to the conservation of plant species diversity in landscapes dominated by high-input agriculture. Such landscape-compatible stands (BfN, 2012) can enhance landscape structure and habitat connectivity. By contrast, large-scale, homogenous SRC cannot be expected to enhance plant species diversity, even in intensively managed landscapes. Potential governmental subsidies for SRC (i.e. in the form of agri-environment measures or the recognition as ecological focus areas) should only support structurally diverse, low-input SRC. Additionally, schemes should allow for site-specific decision making in order to avoid the conversion of valuable, species rich farmland habitats to SRC. 


\subsection{References}

Bärwolff, M., Oswald, M., Biertüpfel, A. (2012) Ökonomische und ökologische Bewertung von Agroforstsystemen in der landwirtschaftlichen Praxis, Teilvorhaben 1: Standort Thüringen, Gesamtkoordination, Final report, http://tinyurl.com/n5fr3wt (accessed 20 November 2014).

Bärwolff, M., Vetter, A., Böhm, C., Hoffmann, J., Schmidt, C. (2011) Was bringen Streifen-KUP? Energie Pflanzen, 2, 9-11.

Baum, S., Bolte, A., Weih, M. (2012a) High value of short rotation coppice plantations for phytodiversity of rural landscapes. Global Change Biology - Bioenergy, 4, 728-738.

Baum, S., Weih, M., Bolte, A. (2012b) Stand age characteristics and soil properties affect species composition of vascular plants in short rotation coppice plantations. BioRisk, 7, 51-71.

Baum, S., Weih, M., Busch, G., Kroiher, F., Bolte, A. (2009) The impact of short rotation coppice plantation on phytodiversity. Landbauforschung - vTI Agriculture and Forestry Research, 59 (3), 163-170.

Britt, C. P., Fowbert, J., McMillan, S. D. (2007) The ground flora and invertebrate fauna of hybrid poplar plantations: results of ecological monitoring in the PAMUDEAE project. Aspects of Applied Biology, 82, 83-90.

Bundesamt für Naturschutz (BfN) (2002) BiolFlor - Eine Datenbank mit biologisch-ökologischen Merkmalen der Flora von Deutschland. Contributors: S. Klotz, I. Kühn und W. Durka, Federal Agency for Nature Conservation, Schriftenreihe für Vegetationskunde, 38.

Bundesamt für Naturschutz (BfN) (2010) Bioenergie und Naturschutz. Synergien fördern, Risiken vermeiden. Federal Agency for Nature Conservation, Bonn.

Bundesamt für Naturschutz (BfN) (2012) Energieholzanbau auf landwirtschaftlichen Flächen. Auswirkungen von Kurzumtriebsplantagen auf Naturhaushalt, Landschaftsbild und biologische Vielfalt. Anbauanforderungen und Empfehlungen des BfN. Federal Agency for Nature Conservation, Leipzig.

Bundesamt für Naturschutz (BfN) (2014) FloraWeb. Federal Agency for Nature Conservation, www.floraweb.de (accessed 7 April 2014).

Caslin, B., Finnan, J., McCracken, A. (eds) (2010) Short rotation coppice willow - best practice guidelines. http://www.seai.ie/Renewables/Bioenergy/Willow_Best_Practice_Guide_2010.pdf, (accessed 11 April 2014).

Conrady, D. (2007) Niederwälder in Nordrhein-Westfalen - Beiträge zur Ökologie, Geschichte und Erhaltung (ed LANUV), Landesamt für Natur, Umwelt und Verbraucherschutz NordrheinWestfalen, Fachbericht 1, pp. 339-359.

Cunningham, M. D., Bishop, J. D., McKay, H. V., Sage, R. B. (2004) ARBRE monitoring - Ecology of short rotation coppice (ed DTI), UK. http://webarchive.nationalarchives.gov.uk/ +/http://www.berr.gov.uk/files/file14870.pdf, last accessed 12/04/2014.

Dauber, J., Jones, M. B., Stout, J. C. (2010) The impact of biomass crop cultivation on temperate biodiversity. Global Change Biology - Bioenergy, 2 (6), 289-309.

Delarze, R., Ciardo, F. (2002) Rote Liste-Arten in Pappelplantagen. Informationsblatt Forschungsbereich Wald, 9, 3-4.

Dölle, M., Schmidt, W. (2009) Impact of tree species on nutrient and light availability: evidence from a permanent plot study of old-field succession. Plant Ecology, 203, 273-287.

Ellenberg, H., Leuschner, C. (2010) Vegetation Mitteleuropas mit den Alpen. 6. ed., Eugen Ulmer $\mathrm{KG}$, Stuttgart.

Fry, D. A., Slater, F. M. (2009) The biodiversity of short rotation willow in the Welsh landscape. Project report, Aberystwyth University.

Gabriel, D., Sait, S. M., Kunin, W. E., Benton, T. G. (2013) Food production vs. biodiversity: comparing organic and conventional agriculture. Journal of Applied Ecology, 50, 355-364. 
Georgi, R., Helbig, C., Müller, M. (2013) Biotische und abiotische Schäden in Kurzumtriebsplantagen, in Energieholzplantagen in der Landwirtschaft (eds Bemmann, A., Butler-Manning, D.), Agrimedia Verlag, Clenze, pp. 42-48.

Georgi, R., Müller, M. (2013) Schadinsekten und Krankheiten in Kurzumtriebsplantagen. DLGMerkblatt 392, DLG e.V., Frankfurt am Main.

Glaser, T. and Schmidt, P. A. (2010) Auswirkungen von Kurzumtriebsplantagen auf die Phytodiversität, in Agrowood. Kurzumtriebsplantagen in Deutschland und europäische Perspektiven, (eds Bemmann, A. and Knust, C.), pp. 153-169. Weißensee Verlag, Berlin.

Gustafsson, L. (1987) Plant conservation aspects of energy forestry - a new type of land use in Sweden. Forest Ecology and Management, 21, 141-161.

Handbuch Forstliche Analytik (HFA) (2005) Eine Loseblatt-Sammlung der Analysemethoden im Forstbereich (ed Gutachterausschuss Forstliche Analytik), Handbuch Forstliche Analytik Grundwerk.

Hardcastle, P. D. (2006) A review of the potential impacts of short rotation forestry - Final Report. http://www.forestry.gov.uk/pdf/SRFFinalReport27Feb.pdf/\$FILE/SRFFinalReport27Feb.pdf (accessed 11 April 2014).

Hartmann, L., Lamersdorf, N. (2015) Site conditions, initial growth and nutrient and litter cycling of newly installed short rotation coppice and agroforestry systems, in Bioenergy from dendromass for the sustainable development of rural areas (eds Butler Manning, D., Bemmann, A., Bredemeier, M., Lamersdorf, N., Ammer, C.), Wiley-VCH Verlag GmbH \& Co. KGaA.

Harvolk, S., Kornatz, P., Otte, A., Simmering, D. (2014) Using existing landscape data to assess the ecological potential of Miscanthus cultivation in a marginal landscape. Global Change Biology: Bioenergy, 6, 227-241.

Hoogeveen, Y., Petersen, J.-E., Gabrielsen, P. (2005) Agriculture and biodiversity in Europe, in Highlevel Pan-European Conference on Agriculture and Biodiversity, Paris (France), 5-7 June 2002, Compendium of background reports (ed Council of Europe Publishing), Nature and Environment, 133, 41-68.

Lamers, P., Marchal, D., Schouwenberg, P. P., Cocchi, M., Junginger, M. (2012) Global wood chip trade for energy (ed IEA Bioenergy Task 40 Sustainable International Bioenergy Trade). http://www.bioenergytrade.org/downloads/t40-global-wood-chips-study_final.pdf (accessed 09 April 2014).

Ludwig, G., Schnittler, M. (1996) Rote Liste gefährdeter Pflanzen Deutschlands, Bonn, Bundesamt für Naturschutz Schriftenreihe für Vegetationskunde, 28.

Meyer, S., Wesche, K., Krause, B., Leuschner, C., Rejmanek, M. (2013) Dramatic losses of specialist arable plants in Central Germany since the 1950s/60s - a cross-regional analysis. Diversity and Distributions, 19, 1175-1187.

NABU (ed) (2008) Energieholzproduktion in der Landwirtschaft - Chancen und Risiken aus Sicht des Natur- und Umweltschutzes, Warlich Druck GmbH, Meckenheim.

Rowe, R. L., Street, N. R., Taylor, G. (2009) Identifying potential environmental impacts of largescale deployment of dedicated bioenergy crops in the UK. Renewable and Sustainable Energy Reviews, 13, 260-279.

Seifert, C., Leuschner, C., Meyer, S., Culmsee, H. (2014) Inter-relationships between crop type, management intensity and light transmissivity in annual crop systems and their effect on farmland plant diversity. Agriculture, Ecosystems and Environment, 195, 173-182.

Sibbesen, E. (1977) A simple ion-exchange resin procedure for extracting plant-available elements from soil. Plant and Soil, 46, 665-669.

Simmering, D., Waldhardt, R., Otte, A. (2013) Erfassung und Analyse der Pflanzenartenvielfalt in der „Normallandschaft" - Ein Beispiel aus Mittelhessen. Berichte der Reinhold-Tüxen-Gesellschaft, 25, 73-94.

Steffan-Dewenter, I., Tscharntke, T. (1997) Early succession of butterfly and plant communities on set-aside fields. Oecologia, 109, 294-302. 
Storkey, J., Meyer, S., Still, K. S., Leuschner, C. (2012) The impact of agricultural intensification and land-use change on the European arable flora. Proceedings of the Royal Society B: Biological Sciences, 279, 1421-1429.

Tscharntke, T., Batáry, P., Dormann, C. F. (2011) Set-aside management: How do succession, sowing patterns and landscape context affect biodiversity? Agriculture, Ecosystems and Environment, 143, $37-44$.

Tubby, I., Armstrong, A. (2002) Establishment and Management of Short Rotation Coppice Practice Note (ed Forestry Commission), Edinburgh. http://www.forestry.gov.uk/PDF/ fcpn7.pdf/\$FILE/fcpn7.pdf, (accessed 09 April 2014).

Unseld, R., Reppin, N., Eckstein, K., Zehlius-Eckert, W., Hoffmann, H., Huber, T. (2011) Leitfaden Agroforstsysteme - Möglichkeiten zur naturschutzgerechten Etablierung von Agroforstsystemen (ed Federal Agency for Nature Conservation), Munich, Germany.

Verheyen, K., Guntenspergen, G. R., Biesbrouck, B., Hermy, M. (2003) An integrated analysis of the effects of past land use on forest herb colozination at landscape scale. Journal of Ecology, 91, 731-742.

Vonk, M. (2008) Energiehout biodiverser dan gedacht. Vakblad Natuur Bos Landschap, 1, 9-11.

Weih, M. (ed) (2008) Short rotation forestry (SRF) on agricultural land and its possibilities for sustainable energy supply. http://www.norden.org/en/publications/publikationer/2008543/at_download/publicationfile, (accessed 10 April 2014).

Wesche, K., Krause, B., Culmsee, H., Leuschner, C. (2012) Fifty years of change in Central European grassland vegetation: Large losses in species richness and animal-pollinated plants. Biological Conservation, 150, 76-85.

Wilmanns, O. (1998) Ökologische Pflanzensoziologie - Eine Einführung in die Vegetation Mitteleuropas. 6. ed., Quelle \& Meyer, Wiesbaden.

Yang, Y., Luo, Y. (2011) Carbon: nitrogen stoichiometry in forest ecosystems during stand development. Global Ecology and Biogeography, 20, 354-361. 


\section{Chapter 5}

\section{Synthesis}

\subsection{Influences of energy cropping on the plant diversity of agricultural landscapes}

\subsubsection{Annual energy crops (maize, oilseed rape)}

\subsubsection{Research context and approaches}

The assessments of the biodiversity impacts of annual energy crops presented in this thesis mainly focussed on maize cultivation for biogas. This focus was chosen to reflect current research priorities. The rapid expansion of maize cultivation has caused major concerns among scientists, conservationists and also among the wider public about negative ecological impacts of energy cropping. The concerns are fuelled by the fact that in regions with a strong focus on livestock farming the agricultural landscape is today characterized by maize production. In north-west Germany, the share of maize of the total arable land typically exceeds 50\% and can reach up to 76\% (DMK, 2010a). This equals shares of $30-48 \%$ of the total agriculturally used area (including grasslands) in these regions (DMK, 2010b). Tall-growing maize is characterizing the landscapes and these rapid changes in crop frequencies are widely perceived by the public. Oilseed rape, the second important energy crop in Germany, is not reaching such high densities in any German region. A theoretical maximum of 25$33 \%$ of the arable land can be cultivated with oilseed rape each year as this crop cannot be grown repeatedly without interruptions on the same field. Additionally, it is not tall-growing and its beautiful flowering aspect in late spring enhances recreational landscape quality for people. Concerns about negative ecological impacts of oilseed rape production are therefore much less commonly voiced, although for instance Diekötter et al. (2010) found oilseed rape production to distort plant-pollinator interactions in the landscape surrounding the fields. We therefore also, additionally, included oilseed rape in the assessments in chapter 3 to account for its importance in the study areas. All assessments were carried out in two study regions in Central Germany, the Lower Saxon hills and the Thuringian Basin, both characterized by fertile arable soils. These regions can be regarded as representative of landscapes with a high prevalence of arable farming. All surveys were done in fields managed conventionally or under an agri-environmental scheme as part of the usual farming activities in the study areas. Vegetation surveys, soil sampling and measurements of PAR transmissivity took place in mature crop stands approximately 1-6 weeks before harvesting of the specific crop. 


\subsubsection{Key findings}

Arable plant diversity and growing conditions in the field interior and at the field margins

We found the field interior of all crops, energy crops as well as food and/or fodder crops, under conventional, high-input management to be extremely species poor. We recorded on average 6 species $100 \mathrm{~m}^{-2}$ in maize $(\mathrm{n}=71), 3$ species $100 \mathrm{~m}^{-2}$ in winter-sown wheat and barley $(\mathrm{n}=71$ and 64 respectively) and 5 species $100 \mathrm{~m}^{-2}$ in oilseed rape $(\mathrm{n}=10)$. Other studies from Central Germany also found the field interior to be extremely impoverished with regard to arable plant diversity. Meyer et al. (2013) found on average 6 species $100 \mathrm{~m}^{-2}$ in conventionally managed fields of different crops on loamy soils. These strikingly low numbers, in conjunction with the low cover values recorded (median across all crops $<0.5 \%$ total weed cover), indicate that the interior of arable fields must represent an extremely impoverished habitat for insects, birds and mammals. In accordance with Parish et al. (2009), this illustrates that today far less than $1 \%$ of the total summer biomass of high-input arable fields consists of non-crop arable plants. Only those animals able to survive by solely feeding on and reproducing in the crop itself, i.e. crop pests, can persist in such homogeneous environments. Most animals, including many pest predators, depend upon more heterogeneous habitats in terms of floristic diversity.

A particularly concerning result of this study was that we found the margins of maize fields to be even less species rich (on average 11 species $100 \mathrm{~m}^{-2}, \mathrm{n}=71$ ) than the margins of fields with winter-sown wheat ( 15 species $\left.100 \mathrm{~m}^{-2}, \mathrm{n}=71\right)$. Winter-sown barley exhibited intermediate species richness with 13 species $100 \mathrm{~m}^{-2}(\mathrm{n}=64)$, whereas oilseed rape harboured on average 15 species $100 \mathrm{~m}^{-2}(n=10)$. These results are largely in accordance with Waldhardt et al. (2011) who found on average 18 species $100 \mathrm{~m}^{-2}$ on maize field margins, but 27 species in winter-sown wheat, 30 species in winter-sown barley and 28 species in oilseed rape in Southern Hesse. Differences in overall species numbers between the two studies are thought to originate from differences in the regional species pools between Southern Hesse, the Lower Saxon hills and the Thuringian Basin.

Field margins of maize fields were also found to be more strongly shaded than margins of other crop fields. PAR transmissivity to the ground reached on average only $11 \%$ in maize field margins, but $18 \%$ in field margins of winter-sown wheat and $19 \%$ in winter-sown barley and oilseed rape. The shading effect of the crop was found to explain a significant part $\left(\mathrm{R}^{2}\right.$ adjusted $\left.=7.7 \%\right)$ of the plant species richness at the field margins. As opposed to the field interior, field margins were found to be suitable habitats for a wide variety of arable plant species. Although they represent only approximately $4 \%$ of the total cropland (Hötker \& Leuschner, 2014), field margins are the last refuges for a wide range of arable plants (Marshall \& Moonen, 2002; Fried et al., 2009). The effects of the expansion of maize cropping on the arable plant diversity of field margins are therefore particularly important at the landscape scale with regard to the maintenance of arable plant diversity. 
Growing conditions for arable plants in the field interior are worse than at the field margins due to a range of different factors concerning the field management and related abiotic factors. Contrary to the field margins, the field interior receives the full fertiliser and herbicide doses and is not influenced as strongly by adjacent, potentially more species rich, habitat types (Wilson \& Aebischer, 1995). The crop cover in the field interior and concomitantly also the yields are therefore typically higher than at the field margins (Sparkes et al., 1998). Consequently, the light transmissivity is lower in the field interior, with maize having the strongest shading effect. On average $6 \%$ of the incoming PAR reached the ground in maize fields, $13 \%$ in oilseed rape, $11 \%$ in barley and $10 \%$ in wheat fields. Differences between the four assessed crops explained $23.4 \%\left(\mathrm{R}^{2}\right.$ adjusted $)$ of the variation in PAR transmissivity at the field level. Maize fields were found to be as dark as fertile grasslands and mature spruce forests, whereas the stands of the other three crops were less shading than temperate grasslands or closed broad-leaved forests (Tappeiner \& Cernusca, 1989; Lane et al., 2000; Ellenberg \& Leuschner, 2010). All conventionally managed crop stands were far more shading than wheat stands managed extensively (i.e. without fertilisation and herbicides applications) according to an agri-environmental scheme with on average 57\% PAR transmissivity. Conventionally managed, high-input crop stands are nowadays probably too dark for many typical light-demanding arable plant species. Considering that the "field interior" is representative of about $96 \%$ of the total arable land (Hötker \& Leuschner, 2014), and that $>90 \%$ of the arable land in Germany are managed conventionally with annual crops or vegetables (excluding fallow arable land, perennial (clover) leys and organic annual crops and vegetables) (Destatis, 2013, 2014), the potentially available habitat for many arable species has been reduced severely during the past 60 years.

\section{The influence of crop choice and field management}

Strong and diverse inter-relationships between different factors affecting arable plant diversity make it extremely difficult to quantify the importance of single predictors. The light transmissivity, for instance, is influenced by the crop stand density which in turn is affected by the choice of crop, the amounts of fertilisation, the herbicide applications and the soil and climatic conditions at the site. All these factors also affect arable plant growth either directly or indirectly by influencing other predictors. With the help of variation partitioning, we aimed to gain insights into this complex network of interdependencies. A complete model with all examined field management, environmental and spatial factors explained 40 and $32 \%$ of the variation in species richness and 42 and $36 \%$ of the variation in community composition for the field interior and the field margin, respectively. These values are high as compared to previous studies by Pinke et al. (2012). The fact that even with a very comprehensive set of predictors only less than $50 \%$ of the variation in arable plant diversity can be explained, illustrates the difficulty of devising simple, straightforward management recommendations for enhancing arable plant diversity within conventional crop systems. The complex interactions of 
different predictors in agroecosystems and the noise which is necessarily generated in the data collection process define the limits of current statistical approaches for this type of assessments.

Field management factors were generally found to be more important than environmental factors when explaining variation in species richness (field interior) and in weed cover (field interior and margin). On the other hand, they were less important than environmental factors for species richness at the field margins and for community composition in the interior and at the margin. These results confirm the hypothesis that field management affects species richness and abundance more strongly than community composition. The latter is thought to be driven more strongly by the environmental conditions which define the local species pools and to respond to changes in field management at much larger time-scales. It also confirms that field management factors exert a stronger influence in the field interior as opposed to the field margin. At the field margins, the explanatory power of the management factors was by $49-86 \%$ smaller than in the field interior for the three response variables. Overall, $6-48 \%$ of the total explained variation in arable plant diversity was attributable to field management factors, whereas $0-49 \%$ was due to varying environmental conditions. The remainder was either attributable to spatial factors or could not be attributed to any of these three groups.

The current crop, fertilisation and to a lesser extent also herbicide use as well as soil characteristics were found to be the most important predictors of arable plant diversity in Central European highinput croplands, apart from spatial factors. Weed cover, species richness and community composition responded to different sets of factors. The current crop was found to potentially explain a substantial amount of the variation in all three response variables. The effect of crop type is thought to originate from crop-specific management practices relating to the timing, quality and quantity of cultivation, fertilisation and herbicide use. Supporting this hypothesis, the crop effects were found to be interrelated with sowing date, fertilisation, herbicide use and crop rotation. Changes in cropping patterns at the landscape scale, such as occurring during the current bioenergy boom, will therefore affect arable plant diversity. The impacts can either be positive or negative. A balanced mixture of maize and winter cereals offers habitats to a wider range of arable plant species than any of these crops alone. On the other hand, the results presented in this thesis also clearly show that the effects of increasing crop diversity on conventionally managed arable land are only of secondary importance as compared to the effects of substantially decreasing land use intensity. Extensively managed fields without fertiliser or herbicides use on nutrient-poor soils showed a much higher plant diversity (on average 21 species $100 \mathrm{~m}^{-2}$ in the field interior and 33 species $100 \mathrm{~m}^{-2}$ at the field margins, including the presence of rare and endangered species) than conventionally managed fields. The type of field management (conventional vs. extensive) alone explained $80 \%$ (gross effect, $\mathrm{R}^{2}{ }_{\text {adjusted }}, \mathrm{n}=20$ ) of the variations in species richness among fields of winter-sown wheat, whereas the current crop was found to explain only $10 \%$ (gross effect, $\mathrm{R}^{2}$ adjusted, $\mathrm{n}=206$, no significant gross effect of crop type found at $\mathrm{n}$ $=40)$ of the variations in species richness among conventionally managed fields. 
Considerable differences in field management were detected between maize, winter-sown wheat and winter-sown barley. Maize fields received about 2-5 times more organic fertilisers (on average 23.6 $\mathrm{Mg} / \mathrm{ha}$ *year, including animal manures and digested residues from biogas plants) than winter cereal fields. As a consequence, the added doses of $\mathrm{P}, \mathrm{K}, \mathrm{Ca}$ and $\mathrm{Mg}$ were 2-6 times higher in maize fields. $\mathrm{N}$-input was not higher on maize fields as compared to winter cereal fields, as higher $\mathrm{N}$-inputs from organic fertilisers were balanced with lower mineral $\mathrm{N}$-fertilisation. As maize growth benefits from high P-doses and the reduction potential with regard to mineral fertilisation is limited, P-fertilisation in maize fields was found to be much higher than in cereal fields. These values are highly alarming. Doses of $>100 \mathrm{~kg} \mathrm{P}_{2} \mathrm{O}_{5} \mathrm{ha}^{-1} \mathrm{yr}^{-1}$, as recorded for almost $50 \%$ of the maize fields, are highly likely to exceed the nutrient removal with maize harvest and can lead to substantial P-leaching to the groundwater with negative effects on a wide range of ecosystems (Sibbesen \& Runge-Metzger, 1995; Sibbesen \& Sharpley, 1997; LWK NRW, 2012).

The herbicide use intensity index (HI) in the study regions was found to be comparable to values found by more comprehensive assessments across Germany (Roßberg, 2011). In accordance with these assessments, herbicide use intensity was found to be higher in maize and winter-sown wheat than in winter-sown barley. The implications of the use of different active ingredients are hard to discern in detail, but our analyses highlight the importance of such assessments. Certain groups of photosynthesis inhibitors at PS II $\left(\mathrm{C}_{1}, \mathrm{C}_{3}\right)$, in our study area mainly represented by terbuthylazine and bromoxynil, are commonly applied in maize cultures, but are not suitable for winter cereals. Group $\mathrm{C}_{2}$ (i.e. isoproturon) on the other hand is suitable for winter cereals, but not for maize. We found the amount of terbuthylazine $\left(\mathrm{C}_{1}\right)$ to potentially affect community composition. In landscapes where maize has become the dominant crop, as for example in certain parts of north-west Germany, such shifts in the herbicides' mechanisms of action can lead to durable shifts in community composition if applied over longer time periods.

Fertilisation was found to be a promising leverage for enhancing arable plant diversity as it was shown to be related to weed cover, species richness and community composition. The quality and quantity of herbicide applications was also shown to be potentially important. Yet, no net effects of changes in nitrogen and phosphorus fertilisation rates were found after partialling out the effects of other management factors. Likewise it could not be discerned why certain groups of herbicides, i.e. mitosis inhibitors (HRAC group $\mathrm{K}_{3}$ ), showed dose-dependent effects on species richness in the field interior, whereas others did not (compare chapter 2). The fact that we did not find clearer dose-dependent effects of fertilisers and herbicides on arable plant diversity maybe due to overall levels of land use intensity being comparatively high on all conventionally managed fields. It has been shown that biodiversity does not respond linearly to changes in land use intensity (Kleijn et al., 2009). There may be thresholds above which a reduction in fertilisation or herbicide use will not affect biodiversity to any measurable extent. Fertiliser and herbicide applications on the surveyed conventionally managed 
fields are likely to have been exceeding such thresholds for many years. Kleijn et al. (2009) found that plant species richness on arable land increased markedly with reductions in fertiliser input only below doses of $100 \mathrm{~kg} \mathrm{~N} \mathrm{ha}^{-1} \mathrm{yr}^{-1}$. Very little change was observed at doses $>150 \mathrm{~kg} \mathrm{~N} \mathrm{ha}^{-1} \mathrm{yr}^{-1}$, as were applied on $93 \%$ of the surveyed fields in the present study during the year of survey or the preceding year. Herbicide applications might exacerbate this effect, as farmers might follow a 'zero-tolerance' strategy with regard to weed infestation independent of the fertilisation rate. As it is difficult to determine optimal application rates for weed management, unnecessary 'insurance' applications of herbicides are also thought to be a common phenomenon complicating the assessment. Our results underline that it will hardly be possible to slow the rapid erosion of biodiversity in agricultural landscapes by solely relying on approaches which reduce land use intensity, but stay within the range of currently practised conventional management techniques.

\subsubsection{Short rotation coppices}

\subsubsection{Research context and approaches}

The second part of the present thesis focused on alternative, 'second generation' energy feedstocks. Short rotation coppices (SRCs), i.e. fast growing trees grown on farmland and repeatedly harvested in cycles of 3-7 (-20) years, are a particularly promising energy feedstock for Central Europe. The expected energy yields per hectare and year can potentially be equally high or even higher than energy yields from the anaerobic digestion of maize (SRU, 2007). As opposed to most other second generation energy crops, native tree species, such as certain native willows and poplars are suitable for cultivation as SRCs. As perennial crops, overall fertiliser and herbicide applications in SRCs are generally expected to be lower than in annual energy crops. SRCs are therefore commonly presented as an ecologically friendly alternative to first generation, annual energy crops. With regard to the effects on biodiversity and more specifically on farmland plant diversity, the impacts of a potential large-scale establishment of SRC are less clear and are therefore in the focus of chapter 4 of this thesis. All assessments presented here are based on vegetation, soil and light transmissivity surveys in 10 SRCs $(5 \times$ willow, $5 \times$ poplar) of different age classes in the Lower Saxon hills and the Thuringian Basin established on former arable land.

\subsubsection{Key findings}

The results clearly confirm the hypothesis that the habitat conditions and concomitantly also the flora of SCRs changes with the age of the plantation. Habitat conditions in the recently (in 2011) established SRCs on arable land were shown to be similar to habitat conditions on fallow arable land, as long a no or only little herbicides and fertilisers are applied on the coppice. The low tree cover 
(1\%), the high PAR transmissivity (on average 89\%), the low soil organic matter content (2.8\%) and the narrow C/N-ratio (9.0) in the upper soil layer in first year SRCs were found to be comparable to arable land which was recently left fallow. Under these conditions relatively species rich plant communities with a high proportion of arable plants (natives as well as archaeophytes) developed. Species richness increased from the first to the second year after establishment from on average 27 species $75 \mathrm{~m}^{-2}$ to 36 species $75 \mathrm{~m}^{-2}$. Tree cover increased as well, but remained mostly clearly below $20 \%$. PAR transmissivity decreased to $66 \%$. Community composition on the first and second year SRCs resembled plant assemblages typical for early successional fallow land (Steffan-Dewenter \& Tscharntke, 1997; Tscharntke et al., 2011). No rare or red-listed species were detected on the coppices.

Species richness in the 5-8 year old willow and poplar plantations was drastically reduced as opposed to the establishment phase. On average 8 species $75 \mathrm{~m}^{-2}$ were recorded in the poplar plantations and 19 species $75 \mathrm{~m}^{-2}$ in the willow coppices. Tree row spacing was wider and light transmissivity higher in the willow coppices (row spacing $>1.5 \mathrm{~m}$; PAR transmissivity approximately $4 \%$ ) as opposed to the poplar stands $(\leq 1 \mathrm{~m} ;<1 \%)$. Mature poplar plantations were found to be darker than maize fields and mature spruce forests and nearly as species poor as arable land (compare chapter 2; Ellenberg \& Leuschner, 2010). The community composition also changed drastically. The importance of arable plant species and archaeophytes decreased strongly. The remaining plant species were in their majority associated with nitrophilous herbaceous vegetation or were habitat generalists. Couch grass (Elymus repens) was the dominant species in the willow coppices. Other important species were stinging nettle (Urtica dioica), hedge bindweed (Calystegia sepium), creeping thistle (Cirsium arvense) and cleavers (Galium aparine), all common generalist weedy species of nitrophilous herbaceous vegetation and arable land. Only one forest species, the wind dispersed milletgrass (Milium effusum), was recorded at one site. Colonisation by most forest species is likely to take much longer than 5-8 years, despite the nearest forests being only 2.0-3.5 km away. Even the time frame of 20-30 years, which is often cited as the maximum age for SRCs (Caslin et al., 2010), might not be enough to allow for the establishment of many herbaceous forest species of high conservation value particularly in agricultural landscapes with little forest cover (Gustafsson, 1987; Hardcastle, 2006). Therefore, and due to the dramatic pace of biodiversity loss in agricultural habitats, it seems appropriate to focus on optimising habitat conditions in SRCs for species associated with cultural landscapes and farmland habitats, rather than for forest species.

Based on these findings and a wider literature review management recommendations for SRCs were given in order to enhance their value as habitats for vascular plants. These recommendations include: (1) avoiding the use of herbicides and fertilisation; (2) cultivating several tree species with a number of different intra-specific genotypes and interspersing other native trees and shrubs; (3) increasing the variability in habitat conditions in time and space in the coppices by choosing a wide tree spacing, using a short harvesting cycle, partially harvesting the coppice at irregular time-steps, decreasing 
plantation size to $\leq 1$ ha and maximising plantation edge length (Delarze \& Ciardo, 2002; NABU, 2008; Weih, 2008; Baum et al., 2012).

\subsubsection{Short rotation coppices - a biodiversity friendly alternative to annual energy crops?}

The question set out in the headline will be answered here with regard to the impacts of both energy cropping systems on the plant diversity of agricultural landscapes. Other taxonomic groups and the wider ecological contexts such as the impacts on soil organic matter accumulation, nutrient leaching, soil erosion and greenhouse gas emission will not be discussed as they are partially still a matter of scientific debate and were not addressed in this thesis.

As outlined in chapters 2 and 3, maize and oilseed rape cultivation as currently practiced on conventional farms are similarly detrimental for farmland plant diversity as the cultivation of wintersown wheat or barley. The field interior of all four crops was found to be extremely species poor. At the margins, maize fields even showed the lowest species richness of all tested crops, likely due to lower light availability.

The results presented in chapter 4 show on the other hand that very dense, structurally homogeneous SRCs can be nearly as species poor as conventionally managed maize or oilseed rape fields. These SRCs were also found to be much more shading than maize fields or even old-growth forests, making them completely unsuitable as habitats for most farmland species. There is a range of easily implemented measures to decrease canopy density, increase the structural diversity and improve the quality of SRCs as habitats for farmland plant species. Adopting these measures will, however, in many cases inevitably result in yield reductions. Consequently, it seems optimistic to expect SRCs to contribute strongly to enhancing the plant diversity of agricultural landscapes without imposing additional requirements. Even less densely planted SRCs, such as the willow coppices surveyed for this study, were shown to mostly provide habitats to a range of common, generalist and mostly problematic weedy species. Their value for plant species conservation in agricultural landscapes is therefore also low, even if species richness is higher than in many maize, oilseed rape or winter cereal fields.

In intensively managed agricultural landscapes it can nevertheless be beneficial for biodiversity to intersperse SRC among the annual energy crops. The concept of planting a number of narrow parallel SRC strips (e.g. 5-20 m width) in regular distances to divide large arable fields planted with annual crops seems particularly well suited for maximising the biodiversity benefits from SRC cultivation (Unseld et al., 2011). These 'agro-forestry systems' can help to increase the habitat diversity of homogeneous, structurally impoverished agricultural landscapes. SRCs are, however, not a suitable 
substitute for the loss of fallow lands or grasslands. They can also not compensate for the current decline in conservation headlands and extensively managed arable land.

The establishment phase of SRC was shown to be the period most interesting from the farmland plant conservation perspective. If the use of herbicides and fertilisers is avoided during the establishment phase, species rich plant assemblages similar to early successional fallow land were shown to develop. Poplars and willows planted as stockings are unfortunately hardly able to compete with this spontaneous arable vegetation resulting in growth delays and initial yield declines if left unmanaged. Weed management can either be done semi-manually with small machines, or with herbicides. Under the scenario that SRCs are cultivated at larger scales, it seems likely that herbicides will be applied routinely during the establishment phase to aid tree establishment and reduce the need for labour intensive mechanical weeding. This would, however, considerably decrease the value of SRC as habitats for farmland plant species. Additional applications of fertiliser to maximise yields would further deteriorate the habitat quality.

Our results show that SRCs cannot be expected to be a suitable tool for halting the rapid erosion of farmland plant diversity. It seems rather necessary to direct their establishment towards intensively managed agricultural landscapes in order to achieve benefits for farmland plant diversity. Appropriate planning procedures also seem paramount to avoid negative impacts which are to be expected if fallow land, low-input grassland or extensively managed arable land is converted to SRC. These sites, making up a considerable proportion of what is commonly referred to as 'marginal land', are the last existing refuges for many plant species in contemporary agricultural landscapes. Their loss would likely counterbalance any positive biodiversity effects of SRC.

Finally, the question arises whether the expansion of SRC cultivation can actually be expected to lead to declines in energy maize or oilseed rape production. Wood chips from SRC are used for energy generation via combustion in combined heat and power plants. They are not suitable as feedstock for anaerobic digestion (biogas production) due to the high content of lignocellulosic compounds and can therefore not be regarded as a direct substitute for energy maize. As wood chips do not contain extractable amounts of vegetable oil, they can also not replace oilseed rape for biodiesel production. At short and intermediate timescales SRC can therefore not be expected to decrease annual energy crop production as biogas plants and biodiesel refineries will keep requiring appropriate feedstocks independent of the developments on the market for solid biofuels. SRCs might, however, contribute to slowing the expansion of annual energy cropping at intermediate timescales. In the long run anaerobic digestion and biodiesel production might even be replaced by more ecologically friendly conversion technologies, such as cogeneration units or biomass to liquid fuels (BtL). As many biogas plants have been established only recently, and are expected to have long operational life spans, there is nevertheless a considerable danger that the widespread cultivation of SRC would additionally increase 
the demand for land for bioenergy feedstocks at least during the next two decades. The negative consequences of increasing land prices due to high demand are already noticeable in contemporary agricultural landscapes. Grasslands are being converted to cropland (BfN, 2014), fallow land is increasingly reconverted to production (Destatis, 2014) and the financial attractiveness of agrienvironmental schemes dwindles (Meyer et al., 2010). In conclusion, it seems necessary to carefully consider all these issues when portraying SRC as a biodiversity friendly alternative to annual energy crop production.

\subsubsection{General conclusions}

In conclusion, the results of this study show clearly that the underlying root causes of the strong decline in arable plant diversity during the last decades extent far beyond energy cropping. Energy cropping was shown to potentially aggravate the situation further but can rather be seen as the "tip of the iceberg'. The impacts of energy cropping also differ widely depending on the structure of the agricultural sector and the soil and climate conditions in different regions. Extremely high proportions of maize on arable land are found for instance in north-west Germany (up to 76\%; DMK, 2010a), whereas the share of maize of the arable land did not exceed $10 \%$ in both study areas.

Negative ecological impacts of energy cropping, particularly of energy maize cultivation, are commonly addressed in the media and are therefore widely discussed. This study highlights that these discussions commonly overlook that the conventional production of winter-sown wheat can be just as intensive as the production of energy maize. Nitrogen fertilisation and herbicide use intensity were shown to be similarly high for maize and winter wheat. Excessive phosphorus fertilisation was, however, discerned as a threat to plant diversity which mainly applies to maize production, due to far higher inputs of organic fertilisers. Maize was also found to be more shading and consequently less species rich at the field margins than winter cereals. On the other hand, we found (summer-sown) maize stands to offer habitats to a different set of arable plant species than fields cultivated with winter-sown crops, such as oilseed rape, wheat or barley. In agricultural landscapes otherwise dominated by winter-sown crops, maize fields can therefore also be expected to positively influence arable plant diversity at the landscape scale.

We concluded that maize and oilseed rape are most detrimental to arable plant diversity if their proportion in the landscape and in the crop rotations becomes too high, or if species-rich, low-input farmland habitats are lost due to energy crop production. These facts indicate that the impacts of energy cropping differ widely between regions. Regionally specific subsidies or the inclusion of energy cropping in the existing landscape planning framework could help to prevent the most detrimental effects on arable plant diversity. 
A similar conclusion as for annual energy crops can also be drawn for SRC. Compared to maize or oilseed rape production, SRC can, however, increase plant diversity if grown in highly intensified production landscapes and managed in a biodiversity-friendly way. The set of species which is likely to survive in SRC after canopy closure differs strongly from the arable plant assemblages found in annual cropping systems. It therefore seems necessary to identify priority groups of species to be targeted by conservation efforts in agricultural landscapes.

\subsection{Open questions, uncertainties and future research perspectives}

This thesis contributed to filling the 'hard data' gap which existed with regards to the consequences of energy crop production on the plant diversity of agricultural landscapes. At the outset of the work in November 2010, only very few publications with vegetation surveys in conventionally managed maize fields, oilseed rape fields and SRC were available (e.g. Mehrtens, 2005; Glemnitz et al., 2008; Baum et al., 2009). Based on field surveys and supported by the questionnaires on field management completed by the participating farmers, it was possible to discern potential relationships between plant diversity metrics and field management, climate and soil conditions and the light regime in energy cropping systems and control plots (conventionally managed winter-sown wheat and barley and wheat fields managed according to an agri-environmental scheme). This thesis can be used as a base for further explorations of the subject.

Many new questions arose on the details of the links between the assessed factors. As for all regression analyses, the correlations found do not necessarily represent genuine causal relationships. The results of the respective regression analyses supported our hypotheses in many cases, in others they led to new open questions. It remains for instance unclear, why the species richness of conventionally managed field margins increased if the sulphur fertilisation was high in the year preceding the survey. This effect might have arisen by chance, but a genuine link cannot be excluded based on current scientific knowledge. All open questions which arose with regard to the validity of the causal relationships assumed can only be answered in an experimental setting where confounding factors can be controlled for.

There are three further sets of research questions which arose during the process of conducting this project. Firstly, it seems important to assess the impacts of energy cropping on biodiversity at the landscape scale. Open questions which remain are for example: (1) Do high proportions of energy maize reduce arable plant diversity at the landscape scale? (2) Is $\beta$-diversity affected by energy cropping? (2) Which proportion of maize, oilseed rape or SRC cultivation is beneficial or tolerable with regard to the maintenance of plant diversity in different regional settings? (3) How should the different energy crops be distributed in the landscape to minimise the threats and maximise the 
benefits for farmland plant diversity? Some of these questions might be answered based on available data gathered during the course of this project, but which could not be analysed until know.

The second important aspect concerns the link between arable plant diversity and other taxonomic groups. Some interesting questions which have not yet been fully addressed in the scientific literature are (1) how is arable plant diversity linked to soil nutrient cycling and to the diversity of the soil macro- and microorganisms? (2) What is the contribution of arable plants to above-ground ecosystem services such as pollination and pest control and how does it relate to the diversity of the respective taxonomic groups? (3) What is the role of the arable flora for maintaining bird diversity in agricultural landscapes? (4) And how are these ecosystem services of arable plants affected by energy cropping?

A third interesting aspect would be to explore possibilities of ranking different management approaches and conservation measures for agricultural landscapes according to their potential for maintaining or enhancing plant diversity in different regional settings. This information would be very useful for policy makers and could help to guide the debate about appropriate measures for biodiversity conservation in agricultural landscapes. Potential questions are for instance: (1) Is it possible to derive objective guidelines to rank or categorize conservation measures according to their function and impact (e.g. in 'fundamental' and 'conditional' measures)? (2) Will such guidelines lead to different rankings in different regional settings? (3) How do segregative and integrative conservation approaches need to be linked in a certain regional setting in order to achieve optimal results in terms of reconciling biodiversity conservation, food and energy production?

\subsection{References}

Baum, S., Weih, M., Bolte, A. (2012) Stand age characteristics and soil properties affect species composition of vascular plants in short rotation coppice plantations. BioRisk, 7, 51-71.

Baum, S., Weih, M., Busch, G., Kroiher, F., Bolte, A. (2009) The impact of short rotation coppice plantation on phytodiversity. Landbauforschung - vTI Agriculture and Forestry Research, 59 (3), $163-170$

BfN (2014) Grünland-Report - Alles im Grünen Bereich? (ed Bundesamt für Naturschutz). http://www.bfn.de/fileadmin/MDB/documents/presse/2014/PK_Gruenlandpapier_30.06.2014_final _layout_barrierefrei.pdf, last accessed 25/07/2014.

Caslin, B., Finnan, J., McCracken, A. (eds) (2010) Short rotation coppice willow - best practice guidelines. http://www.seai.ie/Renewables/Bioenergy/Willow_Best_Practice_Guide_2010.pdf, last accessed 04/11/2014.

Delarze, R., Ciardo, F. (2002) Rote Liste-Arten in Pappelplantagen. Informationsblatt Forschungsbereich Wald, 9, 3-4.

Destatis (2013) Feldfrüchte und Grünland - Ökologischer Landbau in Deutschland 2012: Ackerland und Dauergrünland (geschätzte Werte) (ed Statistisches Bundesamt Deutschland). https://www.destatis.de/DE/ZahlenFakten/Wirtschaftsbereiche/LandForstwirtschaftFischerei/Feldfr uechteGruenland/Tabellen/OekologischesDauergruen_Ackerland2012.html, last accessed $30 / 07 / 2014$. 
Destatis (2014) Feldfrüchte und Grünland - Ackerland nach Hauptfruchtgruppen und Fruchtarten. https://www.destatis.de/DE/ZahlenFakten/Wirtschaftsbereiche/LandForstwirtschaftFischerei/Feldfr uechteGruenland/Tabellen/AckerlandHauptfruchtgruppenFruchtarten.html, last accessed 26/07/2014.

Diekötter, T., Kadoya, T., Peter, F., Wolters, V., Jauker, F. (2010) Oilseed rape crops distort plantpollinator interactions. Journal of Applied Ecology, 47 (1), 209-214. DOI: 10.1111/j.13652664.2009.01759.x.

DMK (2010a) Prozentualer Anteil des Maisanbaus an der Ackerfläche für Deutschland auf Kreisebene 2010 (ed Deutsches Maiskommittee e. V.). http://www.maiskomitee.de/ web/upload/pdf/statistik/dateien_pdf/Vergleich_PAM_AF_PAM_LN_2010.pdf, last accessed 30/07/2014.

DMK (2010b) Prozentualer Anteil des Maisanbaus an der landwirtschaftlichen Nutzfläche für Deutschland auf Kreisebene 2010 (ed Deutsches Maiskommittee e. V.). http://www.maiskomitee.de/web/upload/pdf/statistik/dateien_pdf/Vergleich_PAM_AF_PAM_LN_ 2010.pdf, , last accessed 30/07/2014.

Ellenberg, H., Leuschner, C. (2010) Vegetation Mitteleuropas mit den Alpen. 6. ed., Eugen Ulmer KG, Stuttgart.

Fried, G., Petit, S., Dessaint, F., Reboud, X. (2009) Arable weed decline in Northern France: Crop edges as refugia for weed conservation? Biological Conservation, 142, 238-243.

Glemnitz, M., Hufnagel, J., Platen, R. (2008) Einfluss des Biomasseanbaus für Energiebereitstellung auf die Biodiversität, in Landeskultur in Europa - Lernen von den Nachbarn. Heft 5 (ed Deutsche Landeskulturgesellschaft), Müncheberg, pp. 175-192.

Gustafsson, L. (1987) Plant conservation aspects of energy forestry - a new type of land use in Sweden. Forest Ecology and Management, 21, 141-161.

Hardcastle, P. D. (2006) A review of the potential impacts of short rotation forestry - Final Report. http://www.forestry.gov.uk/pdf/SRFFinalReport27Feb.pdf/\$FILE/SRFFinalReport27Feb.pdf, last accessed 04/11/2014.

Hötker, H., Leuschner, C. (2014) Naturschutz in der Agrarlandschaft am Scheideweg - Misserfolge, Erfolge, nеие Wege. http://www.michaelottostiftung.de/de/presse/left-area/04/text_files/file/ mos015_Studie_RZ_140618_lowres\%202.pdf, last accessed 07/10/2014.

Kleijn, D., Kohler, F., Báldi, A., Batáry, P., Concepción, E. D., Clough, Y. et al. (2009) On the relationship between farmland biodiversity and land-use intensity in Europe. Proceedings of the Royal Society B: Biological Sciences, 276, 903-909.

Lane, D. R., Coffin, D. P., Lauenroth, W. K. (2000) Changes in grassland canopy structure across a precipitation gradient. Journal of Vegetation Science, 11, 359-368.

LWK NRW (2012) Ratgeber - Düngung mit Phosphat, Kali, Magnesium (ed Landwirtschaftskammer Nordrhein-Westfalen).

http://www.landwirtschaftskammer.de/landwirtschaft/ackerbau/pdf/phosphat-kalium-magnesiumpdf.pdf, last accessed 06/06/2014.

Marshall, E. J. P., Moonen, A. C. (2002) Field margins in Northern Europe: their functions and interactions with agriculture. Agriculture, Ecosystems and Environment, 89, 5-21.

Mehrtens, J. (2005) Räumliche und zeitliche Verteilung von Unkräutern in Mais. PhD-thesis, University of Hohenheim, Germany.

Meyer, S., Wesche, K., Krause, B., Leuschner, C. (2013) Dramatic losses of specialist arable plants in Central Germany since the 1950s/60s - a cross-regional analysis. Diversity and Distributions, 19, $1175-1187$.

Meyer, S., Wesche, K., Metzner, J., van Elsen, T., Leuschner, C. (2010) Are current agri-environment schemes suitable for long-term conservation of arable plants? - A short review of different conservation strategies from Germany and brief remarks on the new project '100 fields for diversity'. Aspects of Applied Biology, 100, 287-294. 
NABU (ed) (2008) Energieholzproduktion in der Landwirtschaft - Chancen und Risiken aus Sicht des Natur- und Umweltschutzes, Warlich Druck Meckenheim GmbH, Meckenheim.

Parish, D. M. B., Hawes, C., Hoad, S. P., Iannetta, P. P. M., Squire, G. R. (2009) The contribution of arable weeds to biodiversity, in Weeds: Management, Economic Impacts and Biology (ed R. V. Kingely), Nova Science Publishers, New York, pp. 61-76.

Pinke, G., Karacsony, P., Czucz, B., Botta-Dukat, Z., Lengyel, A. (2012) The influence of environment, management and site context on species composition of summer arable weed vegetation in Hungary. Applied Vegetation Science, 15, 136-144.

Roßberg, D. (2011) Erhebungen zur Anwendung von Pflanzenschutzmitteln in der Praxis im Jahr 2011. Journal für Kulturpflanzen, 65, 141-151.

Sibbesen, E., Runge-Metzger, A. (1995) Phosphorus balance in European agriculture - Status and policy options, in Phosphorus in the global environment: Transfers, cycles, and management (ed H. Tiessen), Wiley, Chichester, New York, SCOPE, 54, 43-57.

Sibbesen, E., Sharpley, A. N. (1997) Setting and justifying upper critical limits for phosphorus in soils, in Phosphorus loss from soil to water (ed H. Tunney), CAB International, Wallingford, New York, pp. 151-176.

Sparkes, D. L., Jaggard, K. W., Ramsden, S. J., Scott, R. K. (1998) The effect of field margins on the yield of sugar beet and cereal crops. Annals of Applied Biology, 132, 129-142. DOI: 10.1111/j.1744-7348.1998.tb05190.x.

SRU (2007) Klimaschutz durch Biomasse - Sondergutachten (ed Sachverständigenrat für Umweltfragen). http://www.umweltrat.de/SharedDocs/Downloads/DE/02_Sondergutachten/ 2007_SG_Biomasse_Buch.pdf;jsessionid=A420C35A6FB0D24EE9CB94D62485DB26.1_cid335? _blob=publicationFile last accessed 07/03/2014.

Steffan-Dewenter, I., Tscharntke, T. (1997) Early succession of butterfly and plant communities on set-aside fields. Oecologia, 109, 294-302.

Tappeiner, U., Cernusca, A. (1989) Canopy structure and light climate of different alpine plant communities: analysis by means of a model. Theoretical and Applied Climatology, 40, 81-92.

Tscharntke, T., Batáry, P., Dormann, C. F. (2011) Set-aside management: How do succession, sowing patterns and landscape context affect biodiversity? Agriculture, Ecosystems and Environment, 143, $37-44$.

Unseld, R., Reppin, N., Eckstein, K., Zehlius-Eckert, W., Hoffmann, H., Huber, T. (2011) Leitfaden Agroforstsysteme - Möglichkeiten zur naturschutzgerechten Etablierung von Agroforstsystemen (ed Federal Agency for Nature Conservation), Munich, Germany.

Waldhardt, R., Otte, A., Simmering, D., Ginzler, O. (2011) Biogas gegen Biodiversität? DLGMitteilungen, 3/2011, 20-23.

Weih, M. (ed) (2008) Short rotation forestry (SRF) on agricultural land and its possibilities for sustainable energy supply. http://www.norden.org/en/publications/publikationer/2008543/at_download/publicationfile, 04/10/2014.

Wilson, P. J., Aebischer, N. J. (1995) The distribution of dicotyledonous arable weeds in relation to distance from the field edge. Journal of Applied Ecology, 32, 295-310. 
Appendix 

Appendix 1.A Data sheet as used for the vegetation survey.

\begin{tabular}{|c|c|c|c|c|c|c|}
\hline No. & Date: & \multirow[t]{2}{*}{ Location: } & \multirow[t]{2}{*}{ Exposition: } & \multirow{2}{*}{\multicolumn{2}{|c|}{ Slope: }} & \multirow[t]{2}{*}{$\begin{array}{l}\text { Elevation a. } \\
\text { s. I.: }\end{array}$} \\
\hline Name: & Quadrat size: & & & & & \\
\hline \multirow[t]{2}{*}{ Edge/Inside: } & \multirow{2}{*}{$\begin{array}{l}\text { Orientation of long } \\
\text { side: }\end{array}$} & Along tractor lane & \multicolumn{4}{|c|}{ Across tractor lanes } \\
\hline & & Edge centre coordinate: & Coord. No.: & & Coo & I. Syst.: \\
\hline \multicolumn{2}{|c|}{ Total plant cover $(\%):$} & Cover moss layer (\%): & \multicolumn{4}{|l|}{ Crop: } \\
\hline \multicolumn{2}{|c|}{ Total crop cover (\%): } & Max. height of crop: & \multicolumn{4}{|c|}{ Mean height of crop (MCH): } \\
\hline \multicolumn{2}{|c|}{ Dev. stage of crop (acc. to BBCH): } & Total cover bare soil (\%): & \multicolumn{4}{|c|}{ Total flower cover (\%): } \\
\hline \multicolumn{2}{|c|}{ Total tree/shrub cover (\%): } & Max. height of tree/shrub layer: & \multicolumn{4}{|c|}{ Mean height of tree/shrub layer: } \\
\hline \multicolumn{2}{|c|}{ Total weed cover (\%): } & Max. height of weeds: & \multicolumn{4}{|c|}{ Mean height of weeds: } \\
\hline \multicolumn{2}{|c|}{ Total cover weed layer $1(\mathrm{WL1},<50 \mathrm{~cm}, \%)$ : } & Max. height of WL1 weeds: & \multicolumn{4}{|c|}{ Mean height of WL1 weeds: } \\
\hline \multicolumn{2}{|c|}{ Total cover weed layer $2(\mathrm{WL2},>50 \mathrm{~cm}, \%)$ : } & Max. height of WL2 weeds: & \multicolumn{4}{|c|}{ Mean height of WL2 weeds: } \\
\hline \multicolumn{2}{|c|}{ Tot. cov. weeds above MCH (WLA): } & Max. height of WLA weeds: & \multicolumn{4}{|c|}{ Mean height of WLA weeds: } \\
\hline \multicolumn{2}{|c|}{ Tot. cov. Weeds below MCH (WLB): } & $\begin{array}{l}\text { Max. height of WLB weeds } \\
=\text { Max. height of crop }\end{array}$ & \multicolumn{4}{|c|}{ Mean height of WLB weeds: } \\
\hline Soil texture: & \multicolumn{2}{|l|}{ Soil description: } & & & \multicolumn{2}{|c|}{ Soil sample no: } \\
\hline
\end{tabular}

Notes:

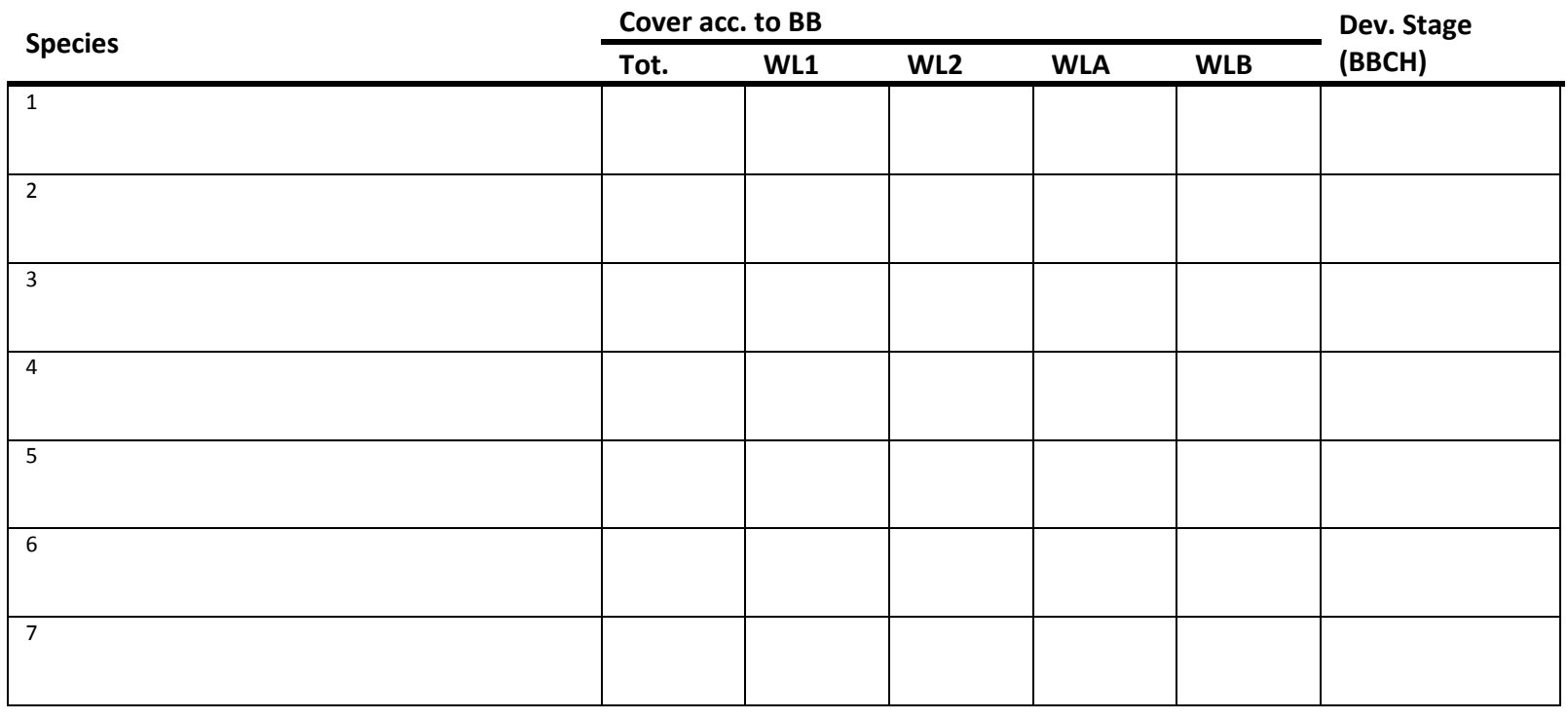

BEST - Bioenergie Regionen Stärken (AP FA 1); C. Seifert, H. Culmsee, C. Leuschner; 2011 
Appendix 1.A

\begin{tabular}{|c|c|c|c|c|c|c|}
\hline \multirow[b]{2}{*}{ Species } & \multicolumn{5}{|c|}{ Cover acc. to BB } & \multirow{2}{*}{$\begin{array}{l}\text { Dev. Stage } \\
\text { (BBCH) }\end{array}$} \\
\hline & Tot. & WL1 & WL2 & WLA & WLB & \\
\hline 8 & & & & & & \\
\hline 9 & & & & & & \\
\hline 10 & & & & & & \\
\hline 11 & & & & & & \\
\hline 12 & & & & & & \\
\hline 13 & & & & & & \\
\hline 14 & & & & & & \\
\hline 15 & & & & & & \\
\hline 16 & & & & & & \\
\hline 17 & & & & & & \\
\hline 18 & & & & & & \\
\hline 19 & & & & & & \\
\hline 20 & & & & & & \\
\hline 21 & & & & & & \\
\hline 22 & & & & & & \\
\hline 23 & & & & & & \\
\hline 24 & & & & & & \\
\hline 25 & & & & & & \\
\hline 26 & & & & & & \\
\hline 27 & & & & & & \\
\hline 28 & & & & & & \\
\hline 29 & & & & & & \\
\hline 30 & & & & & & \\
\hline
\end{tabular}

Notes: 
Appendix 2.A Frequency of occurrence of species recorded on 206 conventionally managed maize, winter wheat and winter barley fields in the Lower Saxon hills and the Thuringian Basin.

\begin{tabular}{|c|c|c|c|c|c|c|c|c|c|}
\hline \multirow[b]{2}{*}{ Species name } & \multicolumn{4}{|c|}{ Field interior } & \multicolumn{4}{|c|}{ Field margin } & \multirow[b]{2}{*}{ Total } \\
\hline & Maize & Wheat & Barley & Sum & Maize & Wheat & Barley & Sum & \\
\hline No. of plots & 71 & 71 & 64 & 206 & 71 & 71 & 64 & 206 & 412 \\
\hline Achillea millefolium & 0 & 0 & 0 & 0 & 0 & 4 & 5 & 9 & 9 \\
\hline Adonis aestivalis & 0 & 0 & 1 & 1 & 1 & 2 & 5 & 8 & 9 \\
\hline Aegopodium podagraria & 0 & 0 & 0 & 0 & 0 & 0 & 1 & 1 & 1 \\
\hline Aethusa cynapium & 3 & 2 & 2 & 7 & 3 & 11 & 3 & 17 & 24 \\
\hline Agrimonia eupatoria & 0 & 0 & 0 & 0 & 0 & 0 & 1 & 1 & 1 \\
\hline Agrostis capillaris & 0 & 0 & 0 & 0 & 0 & 2 & 0 & 2 & 2 \\
\hline Agrostis stolonifera & 0 & 0 & 0 & 0 & 2 & 6 & 4 & 12 & 12 \\
\hline Alliaria petiolata & 0 & 0 & 1 & 1 & 0 & 1 & 2 & 3 & 4 \\
\hline Allium vineale & 0 & 0 & 0 & 0 & 0 & 1 & 0 & 1 & 1 \\
\hline Alopecurus myosuroides & 8 & 9 & 12 & 29 & 13 & 19 & 22 & 54 & 83 \\
\hline Alopecurus pratensis & 0 & 0 & 0 & 0 & 0 & 1 & 1 & 2 & 2 \\
\hline Alyssum alyssoides & 0 & 0 & 0 & 0 & 0 & 1 & 0 & 1 & 1 \\
\hline Amaranthus retroflexus & 4 & 0 & 0 & 4 & 6 & 1 & 0 & 7 & 11 \\
\hline Anagallis arvensis & 2 & 1 & 0 & 3 & 2 & 2 & 0 & 4 & 7 \\
\hline Anagallis foemina & 0 & 0 & 0 & 0 & 0 & 1 & 1 & 2 & 2 \\
\hline Anchusa arvensis & 0 & 0 & 0 & 0 & 0 & 0 & 1 & 1 & 1 \\
\hline Anthemis cotula & 0 & 0 & 0 & 0 & 0 & 2 & 0 & 2 & 2 \\
\hline Anthriscus caucalis & 0 & 0 & 0 & 0 & 0 & 0 & 1 & 1 & 1 \\
\hline Anthriscus sylvestris & 0 & 0 & 0 & 0 & 0 & 1 & 2 & 3 & 3 \\
\hline Apera spica-venti & 1 & 1 & 1 & 3 & 1 & 7 & 2 & 10 & 13 \\
\hline Aphanes arvensis & 0 & 0 & 1 & 1 & 0 & 5 & 4 & 9 & 10 \\
\hline Arabidopsis thaliana & 0 & 0 & 0 & 0 & 0 & 0 & 1 & 1 & 1 \\
\hline Arctium species & 2 & 0 & 1 & 3 & 10 & 12 & 2 & 24 & 27 \\
\hline Arenaria serpyllifolia & 0 & 0 & 0 & 0 & 0 & 1 & 0 & 1 & 1 \\
\hline Arrhenatherum elatius & 0 & 0 & 0 & 0 & 2 & 11 & 6 & 19 & 19 \\
\hline Artemisia vulgaris & 0 & 0 & 0 & 0 & 0 & 2 & 0 & 2 & 2 \\
\hline Asperugo procumbens & 0 & 0 & 0 & 0 & 0 & 0 & 1 & 1 & 1 \\
\hline Atriplex patula & 1 & 2 & 2 & 5 & 4 & 8 & 3 & 15 & 20 \\
\hline Avena fatua & 8 & 3 & 1 & 12 & 10 & 6 & 3 & 19 & 31 \\
\hline Ballota nigra & 0 & 0 & 0 & 0 & 1 & 1 & 1 & 3 & 3 \\
\hline Barbarea vulgaris & 1 & 0 & 0 & 1 & 0 & 1 & 0 & 1 & 2 \\
\hline Bidens species & 1 & 0 & 0 & 1 & 0 & 0 & 1 & 1 & 2 \\
\hline Bromus arvensis & 0 & 0 & 0 & 0 & 1 & 0 & 0 & 1 & 1 \\
\hline $\begin{array}{l}\text { Bromus commutatus ssp. } \\
\text { decipiens }\end{array}$ & 0 & 1 & 3 & 4 & 0 & 7 & 6 & 13 & 17 \\
\hline Bromus hordeaceus & 0 & 0 & 0 & 0 & 0 & 4 & 5 & 9 & 9 \\
\hline Bromus secalinus & 0 & 3 & 2 & 5 & 0 & 8 & 5 & 13 & 18 \\
\hline Bromus sterilis & 4 & 11 & 11 & 26 & 12 & 41 & 41 & 94 & 120 \\
\hline Bryonia dioica & 1 & 0 & 0 & 1 & 0 & 0 & 0 & 0 & 1 \\
\hline Buglossoides arvensis & 0 & 0 & 0 & 0 & 1 & 0 & 1 & 2 & 2 \\
\hline Bunias orientalis & 0 & 0 & 0 & 0 & 0 & 2 & 1 & 3 & 3 \\
\hline Bupleurum rotundifolium & 0 & 1 & 0 & 1 & 0 & 1 & 1 & 2 & 3 \\
\hline
\end{tabular}




\begin{tabular}{|c|c|c|c|c|c|c|c|c|c|}
\hline \multirow[b]{2}{*}{ Species name } & \multicolumn{4}{|c|}{ Field interior } & \multicolumn{4}{|c|}{ Field margin } & \multirow[b]{2}{*}{ Total } \\
\hline & Maize & Wheat & Barley & Sum & Maize & Wheat & Barley & Sum & \\
\hline Calystegia sepium & 2 & 0 & 0 & 2 & 3 & 0 & 1 & 4 & 6 \\
\hline Camelina microcarpa & 0 & 0 & 0 & 0 & 0 & 2 & 0 & 2 & 2 \\
\hline Campanula rapunculoides & 0 & 0 & 0 & 0 & 0 & 1 & 0 & 1 & 1 \\
\hline Capsella bursa-pastoris & 4 & 2 & 0 & 6 & 10 & 7 & 6 & 23 & 29 \\
\hline Carduus acanthoides & 0 & 1 & 0 & 1 & 1 & 9 & 6 & 16 & 17 \\
\hline Carduus crispus & 0 & 0 & 0 & 0 & 1 & 0 & 0 & 1 & 1 \\
\hline Carex hirta & 0 & 0 & 0 & 0 & 1 & 0 & 0 & 1 & 1 \\
\hline Caucalis platycarpos & 0 & 0 & 0 & 0 & 0 & 2 & 4 & 6 & 6 \\
\hline Centaurea cyanus & 0 & 1 & 0 & 1 & 0 & 4 & 0 & 4 & 5 \\
\hline Centaurea jacea & 0 & 0 & 0 & 0 & 0 & 0 & 1 & 1 & 1 \\
\hline Centaurea scabiosa & 0 & 0 & 0 & 0 & 0 & 1 & 2 & 3 & 3 \\
\hline Chaerophyllum aureum & 0 & 0 & 0 & 0 & 1 & 0 & 0 & 1 & 1 \\
\hline Chaerophyllum temulum & 0 & 0 & 0 & 0 & 0 & 1 & 0 & 1 & 1 \\
\hline Chenopodium album & 24 & 18 & 11 & 53 & 32 & 37 & 22 & 91 & 144 \\
\hline Chenopodium hybridum & 9 & 0 & 1 & 10 & 11 & 1 & 0 & 12 & 22 \\
\hline Cichorium intybus & 0 & 0 & 0 & 0 & 0 & 0 & 1 & 1 & 1 \\
\hline Cirsium arvense & 15 & 6 & 8 & 29 & 39 & 35 & 33 & 107 & 136 \\
\hline Cirsium vulgare & 0 & 0 & 0 & 0 & 3 & 7 & 1 & 11 & 11 \\
\hline Consolida ajacis & 0 & 0 & 0 & 0 & 0 & 1 & 0 & 1 & 1 \\
\hline Consolida regalis & 0 & 2 & 2 & 4 & 1 & 9 & 6 & 16 & 20 \\
\hline Convolvulus arvensis & 15 & 8 & 10 & 33 & 35 & 45 & 37 & 117 & 150 \\
\hline Cruciata laevipes & 0 & 1 & 0 & 1 & 0 & 1 & 0 & 1 & 2 \\
\hline Dactylis glomerata & 0 & 0 & 0 & 0 & 14 & 10 & 11 & 35 & 35 \\
\hline Daucus carota & 0 & 0 & 0 & 0 & 1 & 5 & 1 & 7 & 7 \\
\hline Deschampsia cespitosa & 0 & 0 & 0 & 0 & 0 & 1 & 0 & 1 & 1 \\
\hline Descurainia sophia & 0 & 1 & 1 & 2 & 1 & 16 & 11 & 28 & 30 \\
\hline Echinochloa crus-galli & 15 & 0 & 0 & 15 & 14 & 1 & 0 & 15 & 30 \\
\hline Echinops sphaerocephalus & 0 & 0 & 0 & 0 & 0 & 1 & 1 & 2 & 2 \\
\hline Elymus repens & 12 & 3 & 4 & 19 & 36 & 51 & 34 & 121 & 140 \\
\hline Epilobium angustifolium & 0 & 0 & 0 & 0 & 0 & 1 & 0 & 1 & 1 \\
\hline Epilobium ciliatum & 0 & 0 & 0 & 0 & 0 & 1 & 3 & 4 & 4 \\
\hline Equisetum arvense & 7 & 3 & 0 & 10 & 18 & 19 & 11 & 48 & 58 \\
\hline Erodium cicutarium & 1 & 0 & 0 & 1 & 2 & 3 & 2 & 7 & 8 \\
\hline Eryngium campestre & 0 & 0 & 0 & 0 & 0 & 3 & 0 & 3 & 3 \\
\hline Erysimum cheiranthoides & 1 & 0 & 0 & 1 & 1 & 0 & 0 & 1 & 2 \\
\hline Euphorbia cyparissias & 0 & 0 & 0 & 0 & 0 & 3 & 1 & 4 & 4 \\
\hline Euphorbia exigua & 1 & 1 & 2 & 4 & 2 & 6 & 1 & 9 & 13 \\
\hline Euphorbia helioscopia & 10 & 3 & 1 & 14 & 19 & 18 & 10 & 47 & 61 \\
\hline Euphorbia platyphyllos & 1 & 0 & 2 & 3 & 2 & 6 & 3 & 11 & 14 \\
\hline Falcaria vulgaris & 1 & 0 & 0 & 1 & 5 & 4 & 8 & 17 & 18 \\
\hline Fallopia convolvulus & 37 & 31 & 19 & 87 & 51 & 49 & 29 & 129 & 216 \\
\hline Festuca ovina ag. & 0 & 0 & 0 & 0 & 0 & 1 & 2 & 3 & 3 \\
\hline Festuca pratensis & 1 & 0 & 0 & 1 & 2 & 4 & 3 & 9 & 10 \\
\hline Festuca rubra ag. & 0 & 0 & 0 & 0 & 1 & 5 & 1 & 7 & 7 \\
\hline Fragaria viridis & 0 & 0 & 0 & 0 & 0 & 0 & 1 & 1 & 1 \\
\hline
\end{tabular}




\begin{tabular}{|c|c|c|c|c|c|c|c|c|c|}
\hline \multirow[b]{2}{*}{ Species name } & \multicolumn{4}{|c|}{ Field interior } & \multicolumn{4}{|c|}{ Field margin } & \multirow[b]{2}{*}{ Total } \\
\hline & Maize & Wheat & Barley & Sum & Maize & Wheat & Barley & Sum & \\
\hline Fumaria officinalis & 6 & 4 & 3 & 13 & 6 & 11 & 9 & 26 & 39 \\
\hline Fumaria vaillantii & 1 & 2 & 2 & 5 & 4 & 6 & 7 & 17 & 22 \\
\hline Galeopsis tetrahit & 0 & 0 & 0 & 0 & 0 & 4 & 2 & 6 & 6 \\
\hline Galinsoga quadriradiata & 1 & 0 & 0 & 1 & 1 & 0 & 0 & 1 & 2 \\
\hline Galium album & 0 & 0 & 0 & 0 & 0 & 2 & 1 & 3 & 3 \\
\hline Galium aparine & 23 & 26 & 13 & 62 & 46 & 55 & 40 & 141 & 203 \\
\hline Geranium columbinum & 0 & 0 & 0 & 0 & 1 & 0 & 4 & 5 & 5 \\
\hline Geranium dissectum & 8 & 2 & 2 & 12 & 28 & 15 & 8 & 51 & 63 \\
\hline Geranium molle & 1 & 0 & 0 & 1 & 1 & 0 & 0 & 1 & 2 \\
\hline Geranium pusillum & 12 & 2 & 1 & 15 & 25 & 19 & 19 & 63 & 78 \\
\hline Geum urbanum & 0 & 0 & 0 & 0 & 1 & 3 & 1 & 5 & 5 \\
\hline Glechoma hederacea & 0 & 0 & 0 & 0 & 1 & 2 & 3 & 6 & 6 \\
\hline Gnaphalium uliginosum & 0 & 0 & 0 & 0 & 0 & 0 & 1 & 1 & 1 \\
\hline Helianthus aпnииs & 1 & 0 & 0 & 1 & 0 & 0 & 0 & 0 & 1 \\
\hline Heracleum sphondylium & 0 & 0 & 1 & 1 & 1 & 2 & 3 & 6 & 7 \\
\hline Hieracium aurantiacum & 0 & 0 & 0 & 0 & 0 & 1 & 0 & 1 & 1 \\
\hline Holcus lanatus & 0 & 0 & 0 & 0 & 1 & 1 & 0 & 2 & 2 \\
\hline Holcus mollis & 0 & 0 & 0 & 0 & 0 & 1 & 3 & 4 & 4 \\
\hline Hordeum mигіnит & 0 & 0 & 0 & 0 & 0 & 0 & 1 & 1 & 1 \\
\hline Hypericum perforatum & 0 & 0 & 0 & 0 & 0 & 1 & 3 & 4 & 4 \\
\hline Impatiens glandulifera & 0 & 0 & 0 & 0 & 0 & 0 & 1 & 1 & 1 \\
\hline Juncus bufonius & 0 & 1 & 0 & 1 & 0 & 0 & 0 & 0 & 1 \\
\hline Kickxia elatine & 1 & 0 & 0 & 1 & 0 & 0 & 0 & 0 & 1 \\
\hline Lactuca serriola & 0 & 1 & 0 & 1 & 0 & 7 & 2 & 9 & 10 \\
\hline Lamium album & 0 & 0 & 0 & 0 & 1 & 3 & 0 & 4 & 4 \\
\hline Lamium amplexicaule & 0 & 2 & 1 & 3 & 0 & 4 & 4 & 8 & 11 \\
\hline Lamium purpureum & 5 & 7 & 6 & 18 & 11 & 23 & 15 & 49 & 67 \\
\hline Lapsana communis & 0 & 2 & 1 & 3 & 2 & 7 & 5 & 14 & 17 \\
\hline Lathyrus tuberosus & 1 & 0 & 0 & 1 & 5 & 6 & 6 & 17 & 18 \\
\hline Lepidium draba & 1 & 0 & 0 & 1 & 2 & 3 & 1 & 6 & 7 \\
\hline Lolium multiflorum & 0 & 0 & 1 & 1 & 2 & 0 & 0 & 2 & 3 \\
\hline Lolium perenne & 3 & 0 & 1 & 4 & 8 & 8 & 7 & 23 & 27 \\
\hline Lotus corniculatus & 0 & 0 & 0 & 0 & 0 & 0 & 1 & 1 & 1 \\
\hline Malva neglecta & 0 & 0 & 0 & 0 & 2 & 0 & 0 & 2 & 2 \\
\hline Matricaria discoidea & 0 & 0 & 0 & 0 & 0 & 1 & 2 & 3 & 3 \\
\hline Matricaria recutita & 6 & 1 & 3 & 10 & 8 & 5 & 12 & 25 & 35 \\
\hline Medicago lupulina & 0 & 0 & 0 & 0 & 1 & 2 & 1 & 4 & 4 \\
\hline Medicago sativa & 0 & 0 & 0 & 0 & 2 & 0 & 0 & 2 & 2 \\
\hline Melilotus officinalis & 0 & 0 & 0 & 0 & 0 & 1 & 0 & 1 & 1 \\
\hline Mentha arvensis & 1 & 0 & 0 & 1 & 1 & 0 & 0 & 1 & 2 \\
\hline Mercurialis anпиа & 2 & 0 & 0 & 2 & 3 & 0 & 0 & 3 & 5 \\
\hline Myosotis arvensis & 4 & 6 & 1 & 11 & 4 & 17 & 8 & 29 & 40 \\
\hline Nonea pulla & 0 & 0 & 0 & 0 & 0 & 1 & 0 & 1 & 1 \\
\hline Ononis spinosa & 0 & 0 & 0 & 0 & 0 & 0 & 1 & 1 & 1 \\
\hline Onopordum acanthium & 0 & 0 & 0 & 0 & 0 & 1 & 0 & 1 & 1 \\
\hline
\end{tabular}




\begin{tabular}{|c|c|c|c|c|c|c|c|c|c|}
\hline \multirow[b]{2}{*}{ Species name } & \multicolumn{4}{|c|}{ Field interior } & \multicolumn{4}{|c|}{ Field margin } & \multirow[b]{2}{*}{ Total } \\
\hline & Maize & Wheat & Barley & Sum & Maize & Wheat & Barley & Sum & \\
\hline Panicum sp. & 0 & 0 & 0 & 0 & 1 & 0 & 0 & 1 & 1 \\
\hline Papaver argemone & 0 & 0 & 0 & 0 & 0 & 1 & 0 & 1 & 1 \\
\hline Papaver dubium & 0 & 0 & 0 & 0 & 0 & 2 & 0 & 2 & 2 \\
\hline Papaver rhoeas & 0 & 3 & 4 & 7 & 2 & 27 & 28 & 57 & 64 \\
\hline Pastinaca sativa & 0 & 0 & 0 & 0 & 0 & 0 & 1 & 1 & 1 \\
\hline Persicaria amphibia & 0 & 1 & 1 & 2 & 1 & 1 & 0 & 2 & 4 \\
\hline Persicaria lapathifolia & 9 & 2 & 0 & 11 & 9 & 4 & 3 & 16 & 27 \\
\hline Persicaria maculosa & 1 & 1 & 0 & 2 & 3 & 0 & 1 & 4 & 6 \\
\hline Phleum pratense & 0 & 0 & 0 & 0 & 1 & 2 & 0 & 3 & 3 \\
\hline Phragmites australis & 0 & 0 & 0 & 0 & 3 & 1 & 2 & 6 & 6 \\
\hline Plantago lanceolata & 0 & 0 & 0 & 0 & 1 & 1 & 2 & 4 & 4 \\
\hline Plantago major & 0 & 0 & 0 & 0 & 0 & 1 & 2 & 3 & 3 \\
\hline Plantago media & 0 & 0 & 1 & 1 & 0 & 0 & 1 & 1 & 2 \\
\hline Poa angustifolia & 0 & 0 & 0 & 0 & 0 & 1 & 0 & 1 & $\mathbf{1}$ \\
\hline Роа аппиа & 1 & 2 & 1 & 4 & 2 & 13 & 7 & 22 & 26 \\
\hline Poa pratensis & 0 & 0 & 1 & 1 & 0 & 4 & 6 & 10 & 11 \\
\hline Poa trivialis & 1 & 0 & 1 & 2 & 3 & 10 & 13 & 26 & 28 \\
\hline Polygonatum multiflorum & 0 & 0 & 0 & 0 & 0 & 1 & 0 & 1 & 1 \\
\hline Polygonum aviculare & 29 & 16 & 14 & 59 & 41 & 40 & 32 & 113 & 172 \\
\hline Potentilla anserina & 0 & 0 & 0 & 0 & 3 & 0 & 1 & 4 & 4 \\
\hline Potentilla reptans & 0 & 0 & 0 & 0 & 3 & 5 & 2 & 10 & 10 \\
\hline Ranunculus bulbosus & 0 & 0 & 0 & 0 & 0 & 1 & 0 & 1 & 1 \\
\hline Ranunculus repens & 0 & 0 & 0 & 0 & 0 & 0 & 3 & 3 & 3 \\
\hline Raphanus raphanistrum & 1 & 0 & 1 & 2 & 0 & 1 & 1 & 2 & 4 \\
\hline Reseda lutea & 0 & 0 & 0 & 0 & 0 & 1 & 2 & 3 & 3 \\
\hline Rumex acetosella & 0 & 0 & 0 & 0 & 0 & 1 & 0 & 1 & 1 \\
\hline Rumex crispus & 4 & 0 & 0 & 4 & 6 & 2 & 3 & 11 & 15 \\
\hline Rumex obtusifolius & 0 & 0 & 0 & 0 & 1 & 0 & 0 & 1 & 1 \\
\hline Sanguisorba minor & 0 & 0 & 0 & 0 & 0 & 0 & 1 & 1 & $\mathbf{1}$ \\
\hline Scleranthus anпииs & 0 & 0 & 0 & 0 & 0 & 1 & 0 & 1 & 1 \\
\hline Securigera varia & 0 & 0 & 0 & 0 & 0 & 0 & 1 & 1 & $\mathbf{1}$ \\
\hline Senecio vulgaris & 0 & 0 & 0 & 0 & 1 & 0 & 0 & 1 & $\mathbf{1}$ \\
\hline Setaria pumila & 0 & 0 & 0 & 0 & 2 & 0 & 0 & 2 & 2 \\
\hline Setaria viridis & 1 & 0 & 0 & 1 & 1 & 0 & 0 & 1 & 2 \\
\hline Sherardia arvensis & 0 & 1 & 0 & 1 & 0 & 1 & 0 & 1 & 2 \\
\hline Silene latifolia ssp. alba & 0 & 1 & 0 & 1 & 2 & 3 & 1 & 6 & 7 \\
\hline Silene noctiflora & 3 & 1 & 2 & 6 & 5 & 1 & 0 & 6 & 12 \\
\hline Silene vulgaris & 0 & 0 & 0 & 0 & 0 & 0 & 1 & 1 & 1 \\
\hline Sinapis alba & 2 & 1 & 0 & 3 & 4 & 2 & 0 & 6 & 9 \\
\hline Sinapis arvensis & 1 & 0 & 0 & 1 & 2 & 2 & 6 & 10 & 11 \\
\hline Sisymbrium officinale & 4 & 1 & 1 & 6 & 3 & 5 & 6 & 14 & 20 \\
\hline Solanum nigrum & 9 & 0 & 0 & 9 & 13 & 0 & 1 & 14 & 23 \\
\hline Solidago gigantea & 0 & 0 & 0 & 0 & 0 & 0 & 1 & 1 & 1 \\
\hline Sonchus arvensis & 1 & 0 & 0 & 1 & 1 & 1 & 1 & 3 & 4 \\
\hline Sonchus asper & 1 & 1 & 0 & 2 & 7 & 2 & 1 & 10 & 12 \\
\hline
\end{tabular}




\begin{tabular}{|c|c|c|c|c|c|c|c|c|c|}
\hline \multirow[b]{2}{*}{ Species name } & \multicolumn{4}{|c|}{ Field interior } & \multicolumn{4}{|c|}{ Field margin } & \multirow[b]{2}{*}{ Total } \\
\hline & Maize & Wheat & Barley & Sum & Maize & Wheat & Barley & Sum & \\
\hline Sonchus oleraceus & 0 & 0 & 1 & 1 & 1 & 0 & 1 & 2 & 3 \\
\hline Stachys palustris & 0 & 0 & 0 & 0 & 1 & 0 & 0 & 1 & 1 \\
\hline Stachys sylvatica & 0 & 0 & 0 & 0 & 0 & 0 & 1 & 1 & 1 \\
\hline Stellaria media & 6 & 0 & 0 & 6 & 9 & 2 & 4 & 15 & 21 \\
\hline Symphytum officinale & 1 & 0 & 0 & 1 & 1 & 0 & 0 & 1 & 2 \\
\hline Tanacetum vulgare & 0 & 0 & 0 & 0 & 0 & 1 & 1 & 2 & 2 \\
\hline Taraxacum sp. & 9 & 6 & 0 & 15 & 6 & 9 & 3 & 18 & 33 \\
\hline Thlaspi arvense & 6 & 2 & 3 & 11 & 16 & 14 & 19 & 49 & 60 \\
\hline Tragopogon pratensis & 0 & 0 & 0 & 0 & 1 & 0 & 0 & 1 & 1 \\
\hline Trifolium pratense & 1 & 0 & 0 & 1 & 1 & 0 & 1 & 2 & 3 \\
\hline Trifolium repens & 1 & 0 & 0 & 1 & 0 & 0 & 1 & 1 & 2 \\
\hline $\begin{array}{l}\text { Tripleurospermum } \\
\text { perforatum }\end{array}$ & 5 & 7 & 1 & 13 & 11 & 19 & 15 & 45 & 58 \\
\hline Trisetum flavescens & 0 & 0 & 0 & 0 & 0 & 0 & 1 & 1 & 1 \\
\hline Tussilago farfara & 0 & 0 & 0 & 0 & 1 & 1 & 0 & 2 & 2 \\
\hline Urtica dioica & 1 & 0 & 0 & 1 & 9 & 6 & 6 & 21 & 22 \\
\hline Urtica urens & 0 & 0 & 0 & 0 & 1 & 0 & 0 & 1 & 1 \\
\hline Valerianella locusta & 0 & 0 & 0 & 0 & 0 & 3 & 0 & 3 & 3 \\
\hline Veronica arvensis & 0 & 1 & 0 & 1 & 0 & 5 & 2 & 7 & 8 \\
\hline Veronica chamaedrys & 0 & 0 & 0 & 0 & 0 & 1 & 0 & 1 & 1 \\
\hline Veronica filiformis & 0 & 0 & 0 & 0 & 0 & 1 & 0 & 1 & 1 \\
\hline Veronica hederifolia & 0 & 7 & 3 & 10 & 0 & 16 & 15 & 31 & 41 \\
\hline Veronica persica & 9 & 2 & 0 & 11 & 25 & 22 & 8 & 55 & 66 \\
\hline Veronica polita & 5 & 2 & 3 & 10 & 15 & 7 & 7 & 29 & 39 \\
\hline Vicia cracca & 0 & 0 & 0 & 0 & 2 & 3 & 0 & 5 & 5 \\
\hline Vicia hirsuta & 0 & 0 & 0 & 0 & 4 & 2 & 4 & 10 & 10 \\
\hline Vicia sativa & 0 & 0 & 0 & 0 & 1 & 0 & 0 & 1 & 1 \\
\hline Vicia tenuifolia & 0 & 0 & 0 & 0 & 0 & 0 & 1 & 1 & 1 \\
\hline Vicia tetrasperma & 0 & 0 & 0 & 0 & 4 & 1 & 3 & 8 & 8 \\
\hline Viola arvensis & 20 & 21 & 12 & 53 & 21 & 36 & 32 & 89 & 142 \\
\hline Viola hirta & 0 & 0 & 0 & 0 & 1 & 0 & 0 & 1 & 1 \\
\hline Vulpia myuros & 0 & 1 & 0 & 1 & 0 & 1 & 1 & 2 & 3 \\
\hline Anagallis $s p$. & 0 & 0 & 0 & 0 & 0 & 1 & 0 & 1 & 1 \\
\hline Apiaceae sp. & 0 & 0 & 1 & 1 & 0 & 0 & 1 & 1 & 2 \\
\hline Asteraceae sp. & 0 & 0 & 2 & 2 & 0 & 4 & 7 & 11 & 13 \\
\hline Brassicaceae sp. & 0 & 0 & 0 & 0 & 0 & 2 & 1 & 3 & 3 \\
\hline Bromus sp. & 1 & 0 & 0 & 1 & 0 & 0 & 0 & 0 & 1 \\
\hline Caryophyllaceae sp. & 0 & 0 & 0 & 0 & 0 & 1 & 0 & 1 & 1 \\
\hline Crataegus sp. & 0 & 0 & 0 & 0 & 0 & 3 & 1 & 4 & 4 \\
\hline Epilobium sp. & 0 & 0 & 0 & 0 & 1 & 1 & 0 & 2 & 2 \\
\hline Fumaria sp. & 0 & 2 & 0 & 2 & 1 & 3 & 2 & 6 & 8 \\
\hline Geranium sp. & 0 & 0 & 0 & 0 & 0 & 2 & 0 & 2 & 2 \\
\hline Hieracium sp. & 0 & 0 & 0 & 0 & 1 & 0 & 0 & 1 & 1 \\
\hline Medicago sp. & 0 & 0 & 0 & 0 & 0 & 0 & 1 & 1 & 1 \\
\hline Papaver sp. & 0 & 0 & 0 & 0 & 1 & 1 & 0 & 2 & 2 \\
\hline
\end{tabular}




\begin{tabular}{|c|c|c|c|c|c|c|c|c|c|}
\hline \multirow[b]{2}{*}{ Species name } & \multicolumn{4}{|c|}{ Field interior } & \multicolumn{4}{|c|}{ Field margin } & \multirow[b]{2}{*}{ Total } \\
\hline & Maize & Wheat & Barley & Sum & Maize & Wheat & Barley & Sum & \\
\hline Persicaria sp. & 0 & 0 & 0 & 0 & 0 & 0 & 1 & 1 & 1 \\
\hline Poaceae sp. & 1 & 0 & 0 & 1 & 3 & 0 & 0 & 3 & 4 \\
\hline Ranunculus sp. & 0 & 0 & 2 & 2 & 0 & 0 & 2 & 2 & 4 \\
\hline Rumex sp. & 1 & 0 & 0 & 1 & 4 & 0 & 1 & 5 & 6 \\
\hline Sonchus sp. & 0 & 0 & 0 & 0 & 1 & 1 & 2 & 4 & 4 \\
\hline Trifolium sp. & 0 & 0 & 0 & 0 & 1 & 0 & 2 & 3 & 3 \\
\hline Valerianella sp. & 0 & 0 & 0 & 0 & 0 & 1 & 0 & 1 & 1 \\
\hline Veronica sp. & 0 & 0 & 0 & 0 & 0 & 1 & 0 & 1 & 1 \\
\hline Vicia sp. & 1 & 0 & 0 & 1 & 2 & 0 & 0 & 2 & 3 \\
\hline \multicolumn{10}{|l|}{ Trees/shrubs } \\
\hline Acer negundo & 3 & 0 & 0 & 3 & 4 & 0 & 0 & 4 & 7 \\
\hline Acer sp. & 4 & 2 & 2 & 8 & 5 & 3 & 5 & 13 & 21 \\
\hline Aesculus hippocastanum & 0 & 0 & 0 & 0 & 1 & 0 & 0 & 1 & 1 \\
\hline Carpinus betulus & 0 & 0 & 1 & 1 & 0 & 0 & 2 & 2 & 3 \\
\hline Cornus sp. & 0 & 0 & 0 & 0 & 1 & 0 & 0 & 1 & 1 \\
\hline Fraxinus excelsior & 2 & 5 & 2 & 9 & 2 & 5 & 5 & 12 & 21 \\
\hline Prunus avium & 0 & 0 & 1 & 1 & 0 & 2 & 3 & 5 & 6 \\
\hline Prunus domestica & 0 & 0 & 0 & 0 & 1 & 4 & 1 & 6 & 6 \\
\hline Prunus padus & 0 & 0 & 0 & 0 & 0 & 0 & 1 & 1 & 1 \\
\hline Prunus sp. & 0 & 2 & 0 & 2 & 0 & 0 & 1 & 1 & 3 \\
\hline Prunus spinosa & 0 & 0 & 0 & 0 & 0 & 3 & 1 & 4 & 4 \\
\hline Quercus sp. & 0 & 0 & 0 & 0 & 2 & 0 & 0 & 2 & 2 \\
\hline Robinia pseudoacacia & 1 & 0 & 0 & 1 & 1 & 0 & 0 & 1 & 2 \\
\hline Rosa sp. & 1 & 0 & 0 & 1 & 0 & 1 & 5 & 6 & 7 \\
\hline Rubus fruticosus ag. & 1 & 0 & 0 & 1 & 5 & 8 & 7 & 20 & 21 \\
\hline Tilia sp. & 0 & 0 & 1 & 1 & 0 & 0 & 1 & 1 & 2 \\
\hline \multicolumn{10}{|l|}{ Volunteer crops } \\
\hline Avena sativa & 0 & 0 & 0 & 0 & 1 & 0 & 0 & 1 & 1 \\
\hline Brassica napus & 21 & 7 & 8 & 36 & 18 & 5 & 13 & 36 & 72 \\
\hline Hordeum vulgare & 0 & 6 & 0 & 6 & 0 & 6 & 0 & 6 & 12 \\
\hline Pisum sativum & 0 & 0 & 0 & 0 & 1 & 0 & 0 & 1 & 1 \\
\hline Secale cereale & 0 & 2 & 2 & 4 & 0 & 3 & 4 & 7 & 11 \\
\hline$\times$ Triticosecale & 0 & 2 & 1 & 3 & 0 & 3 & 2 & 5 & 8 \\
\hline Triticum aestivum & 12 & 1 & 24 & 37 & 7 & 0 & 22 & 29 & 66 \\
\hline Triticum durum & 0 & 0 & 1 & 1 & 0 & 0 & 0 & 0 & 1 \\
\hline
\end{tabular}




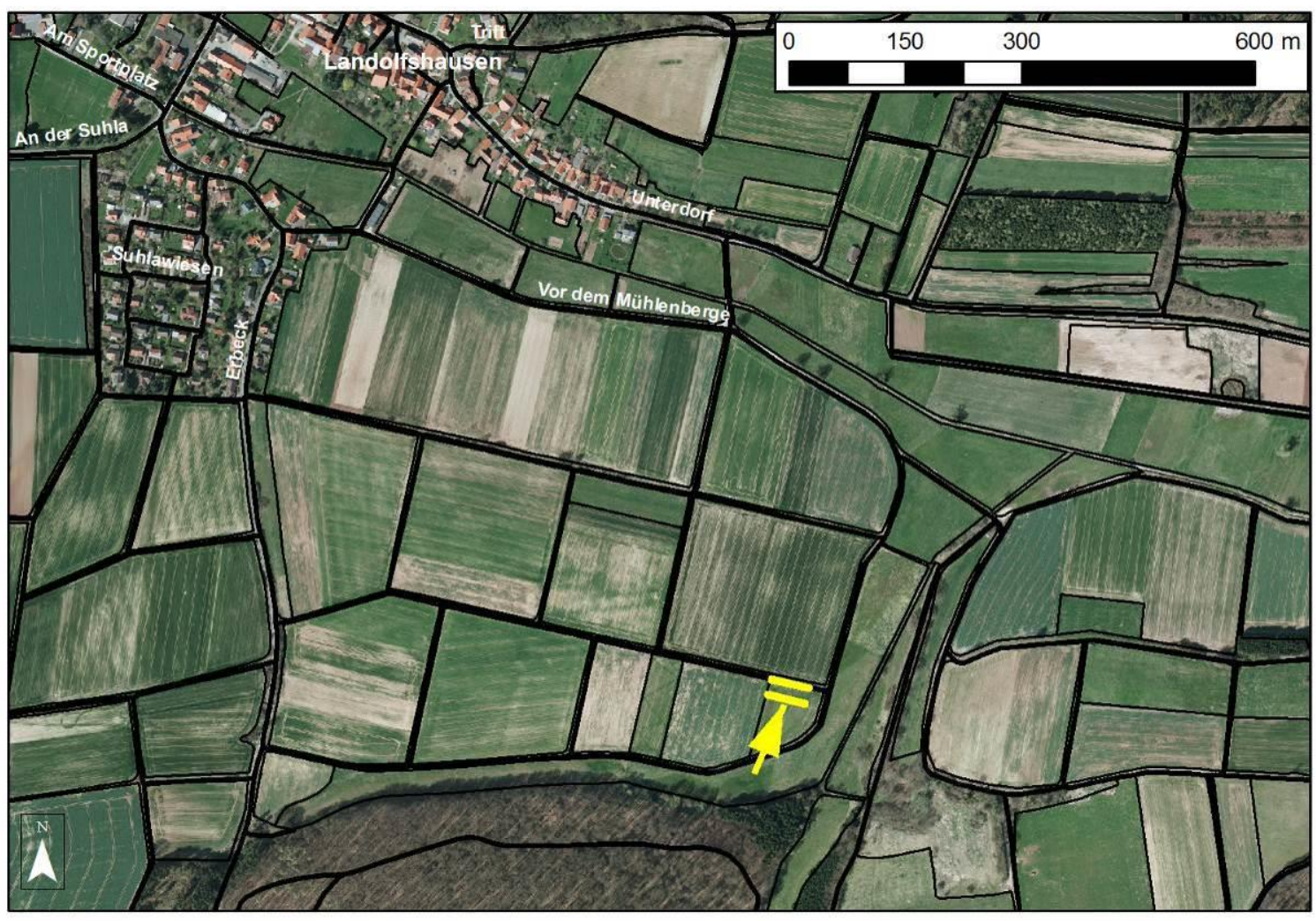

\section{Landnutzungsgeschichte:}

1) Seit wann ist der Schlag Ackerland? (bitte Zutreffendes markieren)

__ seit weniger als 10 Jahren seit 10-15 Jahren seit 15-20 Jahren seit 20-30 Jahren
_ seit 30-50 Jahren
_ seit $50-100$ Jahren seit mehr als 100 Jahren nicht bekannt, aber mindestens seit Jahren

2) Vorherige Nutzung (bitte Zutreffendes markieren):

_ Dauergrünland Wald anders: nicht bekannt

\section{Bemerkungen:}


Fruchtfolge 2002 - 2012:

\begin{tabular}{|c|c|c|c|c|c|c|}
\hline \multirow[b]{2}{*}{ Jahr } & \multirow[b]{2}{*}{ Hauptfrucht } & \multirow[b]{2}{*}{$\begin{array}{l}\text { Nutzung zur } \\
\text { Bioenergie- } \\
\text { produktion? }\end{array}$} & \multicolumn{4}{|c|}{ Anschließend Zwischenfrucht? } \\
\hline & & & Ja & Nein & $\begin{array}{c}\text { Wenn ja, bitte Frucht } \\
\text { angeben. }\end{array}$ & $\begin{array}{l}\text { Nutzung zur } \\
\text { Bioenergie- } \\
\text { produktion? }\end{array}$ \\
\hline 2002 & & & & & & \\
\hline 2003 & & & & & & \\
\hline 2004 & & & & & & \\
\hline 2005 & & & & & & \\
\hline 2006 & & & & & & \\
\hline 2007 & & & & & & \\
\hline 2008 & & & & & & \\
\hline 2009 & & & & & & \\
\hline 2010 & & & & & & \\
\hline 2011 & & & & & & \\
\hline 2012 & & & & & & \\
\hline
\end{tabular}

Bemerkungen: 


\section{Pflanzenschutz}

Anstatt des Eintragens in die unten bereitgestellten Felder können Sie auch einen Ausdruck über den Pflanzenschutz während der letzten beiden Saisons (vom 01. August 2010 - 31. Juli 2012) beifügen.

Bitte darauf achten, dass Datum, Produktbezeichnung und Mengenangaben (mit Einheit!) vorhanden sind!

Vorletzte Saison: 01. August 2010 - 31. Juli 2011

\begin{tabular}{|l|l|l|}
\hline DATUM & PRODUKTBEZEICHNUNG & $\begin{array}{c}\text { MENGE } \\
\text { (in Liter oder Kg pro } \\
\text { Hektar) }\end{array}$ \\
\hline & & \\
\hline & & \\
\hline & & \\
\hline & & \\
\hline & & \\
\hline
\end{tabular}

Letzte Saison: 01. August 2011 - 31. Juli 2012

\begin{tabular}{|l|l|l|}
\hline DATUM & PRODUKTBEZEICHNUNG & $\begin{array}{c}\text { MENGE } \\
\text { (in Liter oder Kg pro } \\
\text { Hektar) }\end{array}$ \\
\hline & & \\
\hline & & \\
\hline & & \\
\hline & & \\
\hline & & \\
\hline
\end{tabular}

Bemerkungen: 


\section{Organische und mineralische Düngemittel}

Bitte Düngemittel eintragen oder Ausdruck beifügen. Bitte darauf achten, dass Datum, Bezeichung und Mengenangaben (mit Einheit!) vorhanden sind!

Bitte organische und mineralische Düngemittel angeben.

Vorletzte Saison: 01. August 2010 - 31. Juli 2011

\begin{tabular}{|l|l|c|}
\hline DATUM & BEZEICHNUNG & $\begin{array}{c}\text { MENGE } \\
\text { (in Liter oder Kg } \\
\text { pro Hektar) }\end{array}$ \\
\hline & & \\
\hline & & \\
\hline & & \\
\hline & & \\
\hline & & \\
\hline & & \\
\hline
\end{tabular}

Letzte Saison: 01. August 2011 - 31. Juli 2012

\begin{tabular}{|l|l|c|}
\hline DATUM & BEZEICHNUNG & $\begin{array}{c}\text { MENGE } \\
\text { (in Liter oder Kg } \\
\text { pro Hektar) }\end{array}$ \\
\hline & & \\
\hline & & \\
\hline & & \\
\hline & & \\
\hline & & \\
\hline & & \\
\hline
\end{tabular}

Bemerkungen: 


\section{Mechanische Bearbeitung (pflügen, grubbern, drillen etc.)}

Zutreffendes bitte ankreuzen:

__ Vollständig pfluglose Bearbeitung seit

Regelmäßig pflügende Bearbeitung seit

Bearbeitung wechselnd je nach Feldfrucht

Bearbeitung anders:

Für die letzten beiden Saisons bitte Art der Bearbeitung und Datum angeben oder Ausdruck beifügen. Besonders wichtig sind das Pflügen und die Aussaattermine.

Vorletzte Saison: 01.August 2010 bis 31. Juli 2011

\begin{tabular}{|l|l|}
\hline DATUM & \multicolumn{1}{c|}{ Art der Bearbeitung } \\
\hline & \\
\hline & \\
\hline & \\
\hline & \\
\hline & \\
\hline & \\
\hline
\end{tabular}

Letzte Saison: 01.August 2011 bis 31. Juli 2012

\begin{tabular}{|l|l|}
\hline DATUM & \multicolumn{1}{c|}{ Art der Bearbeitung } \\
\hline & \\
\hline & \\
\hline & \\
\hline & \\
\hline & \\
\hline & \\
\hline
\end{tabular}

Bemerkungen: 
Appendix 2.C Additional information for the variables soil type (a), geological substrate (b) and the HRAC herbicide categories (c)

(a) Number of plots for each soil type separated by crop and in-field position.

\begin{tabular}{|c|c|c|c|c|c|c|c|c|c|c|}
\hline \multirow[b]{2}{*}{ soil type } & \multirow[b]{2}{*}{ abb. } & \multicolumn{4}{|c|}{ field interior } & \multicolumn{4}{|c|}{ field margin } & \multirow[b]{2}{*}{ total } \\
\hline & & maize & wheat & barley & sum & maize & wheat & barley & sum & \\
\hline Total no. of plots & & 71 & 71 & 64 & 206 & 71 & 71 & 64 & 206 & 412 \\
\hline Vega (alluvial) & $\mathrm{AB}$ & 7 & 1 & 5 & 13 & 7 & 2 & 5 & 14 & 27 \\
\hline Tschernitza (alluvial) & AT & 3 & 2 & 2 & 7 & 2 & 3 & 2 & 7 & 14 \\
\hline Brown Earth & BB & 5 & 6 & 4 & 15 & 5 & 6 & 4 & 15 & 30 \\
\hline Brown Earth - Pelosols & BB-DD & 0 & 1 & 0 & 1 & 0 & 1 & 0 & 1 & 2 \\
\hline Brown-Earth - Regosols & BB-RQ & 1 & 0 & 2 & 3 & 1 & 0 & 2 & 3 & 6 \\
\hline Brown Earth - Pararendzinas & BB-RZ & 0 & 1 & 0 & 1 & 0 & 1 & 0 & 1 & 2 \\
\hline Albeluvisols & $\mathrm{BF}$ & 0 & 0 & 1 & 1 & 0 & 0 & 1 & 1 & 2 \\
\hline Luvisol - Chernozems & BL-TT & 4 & 5 & 1 & 10 & 4 & 5 & 0 & 9 & 19 \\
\hline Pelosols & DD & 9 & 9 & 12 & 30 & 7 & 9 & 13 & 29 & 59 \\
\hline Rendzinas & $\mathrm{RR}$ & 1 & 3 & 1 & 5 & 1 & 3 & 2 & 6 & 11 \\
\hline Pararendzinas & $\mathrm{RZ}$ & 7 & 13 & 9 & 29 & 8 & 13 & 9 & 30 & 59 \\
\hline Stagnosol - Brown Earths & SS-BB & 5 & 1 & 2 & 8 & 5 & 1 & 2 & 8 & 16 \\
\hline Stagnosol - Luvisols & SS-BL & 15 & 12 & 9 & 36 & 15 & 12 & 9 & 36 & 72 \\
\hline Chernozems & TT & 12 & 15 & 14 & 41 & 14 & 14 & 13 & 41 & 82 \\
\hline Chernozem - Luvisols & TT-BL & 0 & 1 & 0 & 1 & 0 & 1 & 0 & 1 & 2 \\
\hline Colluviums & YK & 2 & 0 & 2 & 4 & 2 & 0 & 2 & 4 & 8 \\
\hline
\end{tabular}


(b) Number of plots for each geological substrate separated by crop and in-field position.

\begin{tabular}{|c|c|c|c|c|c|c|c|c|c|}
\hline \multirow[b]{2}{*}{ sediment } & \multicolumn{4}{|c|}{ field interior } & \multicolumn{4}{|c|}{ field margin } & \multirow[b]{2}{*}{ total } \\
\hline & maize & wheat & barley & sum & maize & wheat & barley & sum & \\
\hline Total no. of plots & 71 & 71 & 64 & 206 & 71 & 71 & 64 & 206 & 412 \\
\hline Loess & 25 & 21 & 16 & 62 & 24 & 21 & 15 & 60 & 122 \\
\hline Loess over Bunter Sandstone & 2 & 3 & 1 & 6 & 3 & 3 & 1 & 7 & 13 \\
\hline Loess over Muschelkalk & 1 & 3 & 2 & 6 & 1 & 3 & 1 & 5 & 11 \\
\hline Upper Bunter Sandstone & 4 & 4 & 2 & 10 & 4 & 4 & 2 & 10 & 20 \\
\hline Middle Bunter Sandstone & 2 & 4 & 3 & 9 & 2 & 4 & 3 & 9 & 18 \\
\hline Lower Bunter Sandstone & 1 & 2 & 0 & 3 & 1 & 2 & 0 & 3 & 6 \\
\hline Upper Muschelkalk & 2 & 5 & 3 & 10 & 2 & 5 & 4 & 11 & 21 \\
\hline Middle Muschelkalk & 2 & 4 & 1 & 7 & 2 & 4 & 1 & 7 & 14 \\
\hline Lower Muschelkalk & 1 & 0 & 1 & 2 & 1 & 0 & 1 & 2 & 4 \\
\hline Middle Keuper & 9 & 12 & 16 & 37 & 9 & 11 & 17 & 37 & 74 \\
\hline Lower Keuper & 8 & 6 & 6 & 20 & 9 & 6 & 6 & 21 & 41 \\
\hline $\begin{array}{l}\text { Pleistocene cover sediments over } \\
\text { Bunter Sandstone }\end{array}$ & 0 & 1 & 1 & 2 & 0 & 1 & 1 & 2 & 4 \\
\hline Pleistocene fluvial terraces & 3 & 4 & 5 & 12 & 2 & 4 & 5 & 11 & 23 \\
\hline Glacial till & 0 & 0 & 1 & 1 & 0 & 0 & 1 & 1 & 2 \\
\hline Alluvial sediments (Holocene) & 11 & 2 & 6 & 19 & 11 & 3 & 6 & 20 & 39 \\
\hline
\end{tabular}


(c) HRAC herbicide classification system according to Menne and Köcher (2012). Only groups with substances applied on the study fields are shown.

\begin{tabular}{|c|c|c|c|}
\hline $\begin{array}{l}\text { HRAC } \\
\text { group }\end{array}$ & Mechanism of action & Chemical family & $\begin{array}{l}\text { Number of } \\
\text { fields }\end{array}$ \\
\hline A & ACCase inhibitors & $\begin{array}{l}\text { Aryloxyphenoxy-propionates, } \\
\text { cyclohexanediones, phenylpyrazolines }\end{array}$ & 61 \\
\hline B & ALS/AHAS inhibitors & $\begin{array}{l}\text { Sulfonylureas, imidazolinones, } \\
\text { triazolopyrimidines, } \\
\text { pyrimidinyl(thio)benzoates, } \\
\text { sulfonylaminocarbonyl-triazolinones }\end{array}$ & 197 \\
\hline $\mathrm{C}_{1}$ & PS-II inhibitors & $\begin{array}{l}\text { Triazines, triazinones, triazolinones, } \\
\text { uracils, pyridazinones, phenylcarbamates }\end{array}$ & 105 \\
\hline $\mathrm{C}_{2}$ & PS-II inhibitors & Ureas, amides & 41 \\
\hline $\mathrm{C}_{3}$ & PS-II inhibitors & $\begin{array}{l}\text { Nitriles, benzothiadiazinones, pheny- } \\
\text { pyridazines }\end{array}$ & 63 \\
\hline $\mathrm{E}$ & Protoporphyrinogen oxidase inhibitors & $\begin{array}{l}\text { Dephenyl ethers, phenylpyrazoles, N- } \\
\text { phenylphthalimides, thiadiazoles, } \\
\text { oxadiazoles, oxazolidinediones, } \\
\text { pyrimidindiones, others }\end{array}$ & 44 \\
\hline $\mathrm{F}_{1}$ & $\begin{array}{l}\text { Carotenoid biosynthesis inhibitors } \\
\text { (inhibition of the phytoene desaturase) }\end{array}$ & $\begin{array}{l}\text { Pyridazinones, pyridinecarboxamides, } \\
\text { others }\end{array}$ & 84 \\
\hline $\mathrm{F}_{2}$ & $\begin{array}{l}\text { Carotenoid biosynthesis inhibitors } \\
\text { (inhibition of 4-hydroxyphenyl- } \\
\text { pyruvate-dioxygenase) }\end{array}$ & Triketones, isoxazoles, pyrazoles, others & 45 \\
\hline $\mathrm{F}_{3}$ & $\begin{array}{l}\text { Carotenoid biosynthesis inhibitors } \\
\text { (unknown target) }\end{array}$ & Triazoles, diphenylethers, ureas & 10 \\
\hline $\mathrm{F}_{4}$ & $\begin{array}{l}\text { Carotenoid biosynthesis inhibitors } \\
\text { (inhibition of 1-deoxy-D-xylulose 5- } \\
\text { phosphate synthase) }\end{array}$ & Isoxazolidinones & 3 \\
\hline G & EPSP synthase inhibitors & Glycines (includes glyphosate) & 91 \\
\hline $\mathrm{K}_{1}$ & Inhibitors of microtubule assembly & $\begin{array}{l}\text { Dinitroanilines, phosphoroamidates, } \\
\text { pyridines, benzamides, benzoic acids }\end{array}$ & 18 \\
\hline $\mathrm{K}_{3}$ & $\begin{array}{l}\text { Mitosis inhibitors (inhibition of } \\
\text { VLCFAs) }\end{array}$ & $\begin{array}{l}\text { Chloroacetamides, acetamides, } \\
\text { oxyacetamides, tetrazolinones, others }\end{array}$ & 96 \\
\hline $\mathrm{N}$ & $\begin{array}{l}\text { Inhibitors of lipid synthesis (not } \\
\text { ACCase inhibition) }\end{array}$ & $\begin{array}{l}\text { Thiocarbamates, phosphorodithioates, } \\
\text { benzofurans, chloro-carbonic-acids }\end{array}$ & 11 \\
\hline $\mathrm{O}$ & Synthetic auxins & $\begin{array}{l}\text { Phenoxy-carboxylic-acids, benzoic } \\
\text { acids, pyridine carboxylic acids, } \\
\text { quinolone carboxylic acids }\end{array}$ & 115 \\
\hline
\end{tabular}




\section{Appendix 2.D}

(a) Loadings of the principal components (PCs) from PCA of different groups of environmental variables. PCs were entered in the statistical analyses to avoid problems with collinearity for sets of factors with highly correlated variables (macro environment, fertilisation, crop rotation).

\begin{tabular}{|c|c|c|c|c|}
\hline Principle components & $\mathrm{PC} 1$ & PC2 & PC3 & PC4 \\
\hline \multicolumn{5}{|l|}{ Macro environment } \\
\hline Total explained variation (\%) & 72.3 & 23.6 & & \\
\hline Region & 0.85 & 0.49 & - & - \\
\hline Elevation a. s. 1. & 0.63 & -0.77 & - & - \\
\hline Precipitation & 0.98 & 0.06 & - & - \\
\hline Temperature & -0.90 & 0.40 & - & - \\
\hline Sunshine hours & -0.86 & -0.43 & - & - \\
\hline \multicolumn{5}{|l|}{ Fertilisation (year of survey) } \\
\hline Total explained variation (\%) & 56.7 & 16.9 & 8.3 & 6.8 \\
\hline $\mathrm{N}$ & -0.67 & -0.49 & -0.26 & 0.46 \\
\hline $\mathrm{P}$ & -0.74 & 0.24 & -0.48 & -0.36 \\
\hline K & -0.89 & -0.01 & -0.14 & -0.06 \\
\hline $\mathrm{S}$ & -0.15 & -0.92 & 0.12 & -0.34 \\
\hline $\log \mathrm{Ca}$ & -0.87 & 0.12 & 0.32 & -0.05 \\
\hline $\mathrm{Mg}$ & -0.78 & 0.15 & 0.39 & -0.03 \\
\hline Organic fertilisers & -0.89 & 0.09 & 0.05 & 0.14 \\
\hline \multicolumn{5}{|l|}{ Fertilisation (preceding year) } \\
\hline Total explained variation (\%) & 55.6 & 15.8 & 9.1 & 7.9 \\
\hline $\mathrm{N}$ & -0.66 & 0.42 & -0.01 & -0.62 \\
\hline $\mathrm{P}$ & -0.77 & -0.16 & -0.30 & 0.01 \\
\hline K & -0.86 & -0.08 & -0.29 & 0.07 \\
\hline S & -0.12 & 0.93 & -0.06 & 0.32 \\
\hline $\log \mathrm{Ca}$ & -0.86 & -0.09 & 0.29 & 0.21 \\
\hline $\mathrm{Mg}$ & -0.76 & -0.02 & 0.58 & 0.01 \\
\hline Organic fertilisers & -0.89 & -0.13 & -0.21 & 0.14 \\
\hline \multicolumn{5}{|l|}{ Crop rotation } \\
\hline Total explained variation (\%) & 39.6 & 22.2 & 19.5 & 10.7 \\
\hline \# of crops & 0.17 & -0.16 & -0.83 & 0.46 \\
\hline Prop. of maize & 0.50 & -0.73 & 0.30 & -0.24 \\
\hline Prop. of wheat & -0.79 & 0.30 & 0.18 & -0.19 \\
\hline Prop. of winter crops & -0.85 & 0.36 & 0.00 & 0.12 \\
\hline Prop. of legumes & 0.28 & 0.33 & -0.66 & -0.60 \\
\hline Prop. of fallow/grassland & $\mathbf{0 . 7 0}$ & 0.54 & 0.34 & 0.26 \\
\hline Prop. of biennials/perennials & 0.76 & 0.61 & 0.11 & -0.04 \\
\hline
\end{tabular}

(b) Complete theoretical models before backward selection for each of the six response variables sorted by the nine sets of predictors.

\begin{tabular}{|c|c|}
\hline Set of variables & Full models \\
\hline Crop & 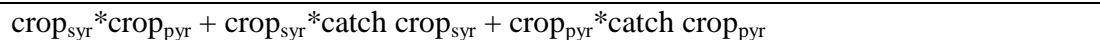 \\
\hline Fertilisation & $\mathrm{PC} 1_{\text {syr }} * \mathrm{PC} 1_{\mathrm{pyr}}+\mathrm{PC} 2_{\text {syr }} * \mathrm{PC} 2_{\mathrm{pyr}}+\mathrm{PC} 3_{\mathrm{syr}} * \mathrm{PC} 3_{\mathrm{pyr}}+\mathrm{PC} 4_{\mathrm{syr}} * \mathrm{PC} 4_{\mathrm{pyr}}$ \\
\hline Herbicides & $\begin{array}{l}\text { intensity index } \\
\mathrm{F} 4+\mathrm{G}+\mathrm{K} 1+\mathrm{K} 3+\mathrm{N}+\mathrm{O}+\mathrm{O}\end{array}$ \\
\hline Conversion tillage & ploughing $\mathrm{y} / \mathrm{n}($ last $2 \mathrm{yrs})+$ ploughing $\mathrm{y} / \mathrm{n}$ (last $5 \mathrm{yrs})$ \\
\hline Crop rotation & $\mathrm{PC} 1+\mathrm{PC} 2+\mathrm{PC} 3+\mathrm{PC} 4$ \\
\hline Land use history & time since conversion to cropland*previous land use \\
\hline Macro environment & PC 1 *PC 2 \\
\hline Micro environment & slope*aspect + crop cover $(+$ tree/shrub cover $)$ \\
\hline Soil $\quad$ & soil type*geological substrate $+\mathrm{pH}+\mathrm{C} / \mathrm{N}$ ratio $+\mathrm{SOM}+\mathrm{P}$ \\
\hline Spatial factors & all positive PCNM variables (103-107, depending on response variable) \\
\hline
\end{tabular}


Appendix 3.A Species list from vegetation surveys on 50 arable fields in the Lower Saxon hills and the Thuringian Basin in the Central Highlands of Germany, giving the number of plots for each cropping system and in-field position of the plot (FI, field interior; FM, field margin), in which the 157 weed species have been recorded. Conv., conventional management; AES, agri-environmental scheme; red list status in Germany (1, critically endangered; 2, endangered; 3, vulnerable; V, near threatened; $\mathrm{D}$, data deficient; *, not threatened) based on Ludwig and Schnittler (1996).

\begin{tabular}{|c|c|c|c|c|c|c|c|c|c|c|c|c|c|c|}
\hline & \multicolumn{6}{|c|}{$\mathrm{FI}$} & \multicolumn{6}{|c|}{ FM } & \multirow{2}{*}{\multicolumn{2}{|c|}{ 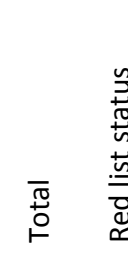 }} \\
\hline & 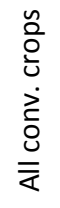 & $\frac{\stackrel{N}{N}}{\sum}$ & 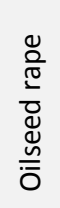 & $\frac{\vec{d}}{\frac{D}{\pi}}$ & 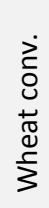 & 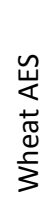 & 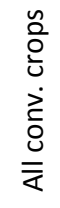 & $\frac{\stackrel{N}{\pi}}{\sum}$ & 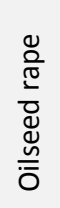 & $\frac{\vec{d}}{\frac{\pi}{\pi}}$ & 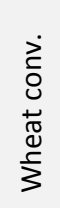 & 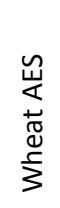 & & \\
\hline $\begin{array}{l}\text { Total number of plots } \\
(n)\end{array}$ & 40 & 10 & 10 & 10 & 10 & 10 & 40 & 10 & 10 & 10 & 10 & 10 & 100 & \\
\hline Achillea millefolium & 0 & 0 & 0 & 0 & 0 & 1 & 2 & 0 & 0 & 1 & 1 & 0 & 3 & * \\
\hline Adonis aestivalis & 0 & 0 & 0 & 0 & 0 & 4 & 1 & 0 & 0 & 1 & 0 & 5 & 10 & 3 \\
\hline Adonis flammea & 0 & 0 & 0 & 0 & 0 & 1 & 0 & 0 & 0 & 0 & 0 & 0 & 1 & 1 \\
\hline $\begin{array}{l}\text { Aegopodium } \\
\text { podagraria }\end{array}$ & 0 & 0 & 0 & 0 & 0 & 0 & 1 & 0 & 1 & 0 & 0 & 0 & 1 & $*$ \\
\hline Aethusa cynapium & 1 & 0 & 0 & 1 & 0 & 1 & 0 & 0 & 0 & 0 & 0 & 2 & 4 & * \\
\hline Agrimonia eupatoria & 0 & 0 & 0 & 0 & 0 & 2 & 0 & 0 & 0 & 0 & 0 & 2 & 4 & * \\
\hline Agrostis stolonifera & 0 & 0 & 0 & 0 & 0 & 0 & 1 & 0 & 0 & 1 & 0 & 1 & 2 & * \\
\hline Allium oleraceum & 0 & 0 & 0 & 0 & 0 & 1 & 0 & 0 & 0 & 0 & 0 & 2 & 3 & * \\
\hline Allium vineale & 0 & 0 & 0 & 0 & 0 & 2 & 0 & 0 & 0 & 0 & 0 & 4 & 6 & * \\
\hline $\begin{array}{l}\text { Alopecurus } \\
\text { myosuroides }\end{array}$ & 7 & 1 & 1 & 2 & 3 & 4 & 14 & 3 & 4 & 3 & 4 & 4 & 29 & $*$ \\
\hline Alopecurus pratensis & 0 & 0 & 0 & 0 & 0 & 0 & 1 & 0 & 0 & 1 & 0 & 0 & 1 & * \\
\hline Alyssum alyssoides & 0 & 0 & 0 & 0 & 0 & 0 & 0 & 0 & 0 & 0 & 0 & 1 & 1 & * \\
\hline Amaranthus retroflexus & 0 & 0 & 0 & 0 & 0 & 0 & 1 & 1 & 0 & 0 & 0 & 0 & 1 & * \\
\hline Anagallis arvensis & 0 & 0 & 0 & 0 & 0 & 4 & 1 & 1 & 0 & 0 & 0 & 7 & 12 & * \\
\hline Anagallis foemina & 0 & 0 & 0 & 0 & 0 & 2 & 0 & 0 & 0 & 0 & 0 & 3 & 5 & * \\
\hline Anthemis cotula & 0 & 0 & 0 & 0 & 0 & 0 & 0 & 0 & 0 & 0 & 0 & 1 & 1 & * \\
\hline Anthriscus sylvestris & 0 & 0 & 0 & 0 & 0 & 0 & 1 & 0 & 1 & 0 & 0 & 0 & 1 & * \\
\hline Apera spica-venti & 0 & 0 & 0 & 0 & 0 & 3 & 2 & 0 & 1 & 0 & 1 & 3 & 8 & * \\
\hline Aphanes arvensis & 0 & 0 & 0 & 0 & 0 & 4 & 2 & 0 & 2 & 0 & 0 & 4 & 10 & * \\
\hline Arctium lappa & 0 & 0 & 0 & 0 & 0 & 0 & 3 & 3 & 0 & 0 & 0 & 0 & 3 & * \\
\hline Arenaria serpyllifolia & 0 & 0 & 0 & 0 & 0 & 5 & 0 & 0 & 0 & 0 & 0 & 4 & 9 & * \\
\hline Arrhenatherum elatius & 0 & 0 & 0 & 0 & 0 & 0 & 8 & 0 & 4 & 1 & 3 & 3 & 11 & * \\
\hline Artemisia vulgaris & 0 & 0 & 0 & 0 & 0 & 0 & 1 & 0 & 0 & 0 & 1 & 0 & 1 & * \\
\hline Asperugo procumbens & 0 & 0 & 0 & 0 & 0 & 0 & 1 & 0 & 0 & 1 & 0 & 0 & 1 & 3 \\
\hline Atriplex patula & 2 & 1 & 0 & 1 & 0 & 1 & 1 & 0 & 1 & 0 & 0 & 1 & 5 & * \\
\hline Avena fatua & 1 & 0 & 0 & 0 & 1 & 3 & 3 & 0 & 1 & 0 & 2 & 2 & 9 & * \\
\hline Barbarea vulgaris & 2 & 1 & 0 & 1 & 0 & 0 & 2 & 0 & 0 & 1 & 1 & 0 & 4 & * \\
\hline Bromus hordeaceus & 0 & 0 & 0 & 0 & 0 & 0 & 1 & 0 & 0 & 1 & 0 & 0 & 1 & * \\
\hline Bromus japonicus & 0 & 0 & 0 & 0 & 0 & 0 & 0 & 0 & 0 & 0 & 0 & 1 & 1 & * \\
\hline Bromus secalinus & 1 & 0 & 0 & 0 & 1 & 1 & 2 & 0 & 0 & 0 & 2 & 1 & 5 & * \\
\hline Bromus sterilis & 2 & 0 & 0 & 1 & 1 & 5 & 15 & 1 & 2 & 5 & 7 & 7 & 29 & * \\
\hline Bunias orientalis & 0 & 0 & 0 & 0 & 0 & 1 & 0 & 0 & 0 & 0 & 0 & 1 & 2 & * \\
\hline $\begin{array}{l}\text { Bupleurum } \\
\text { rotundifolium }\end{array}$ & 0 & 0 & 0 & 0 & 0 & 1 & 0 & 0 & 0 & 0 & 0 & 2 & 3 & 1 \\
\hline Camelina microcarpa & 0 & 0 & 0 & 0 & 0 & 3 & 0 & 0 & 0 & 0 & 0 & 3 & 6 & * \\
\hline Camelina sativa & 0 & 0 & 0 & 0 & 0 & 0 & 1 & 0 & 0 & 0 & 1 & 0 & 1 & * \\
\hline $\begin{array}{l}\text { Campanula } \\
\text { rapunculoides }\end{array}$ & 0 & 0 & 0 & 0 & 0 & 0 & 0 & 0 & 0 & 0 & 0 & 2 & 2 & * \\
\hline Capsella bursa-pastoris & 4 & 1 & 2 & 1 & 0 & 1 & 5 & 0 & 4 & 1 & 0 & 1 & 11 & * \\
\hline Carduus acanthoides & 0 & 0 & 0 & 0 & 0 & 3 & 3 & 0 & 0 & 1 & 2 & 5 & 11 & * \\
\hline Carex hirta & 0 & 0 & 0 & 0 & 0 & 0 & 1 & 1 & 0 & 0 & 0 & 0 & 1 & * \\
\hline Carum carvi & 0 & 0 & 0 & 0 & 0 & 0 & 0 & 0 & 0 & 0 & 0 & 1 & 1 & $\mathrm{~V}$ \\
\hline Caucalis platycarpos & 0 & 0 & 0 & 0 & 0 & 1 & 0 & 0 & 0 & 0 & 0 & 3 & 4 & 3 \\
\hline
\end{tabular}




\begin{tabular}{|c|c|c|c|c|c|c|c|c|c|c|c|c|c|c|}
\hline & \multicolumn{6}{|c|}{$\mathrm{FI}$} & \multicolumn{6}{|c|}{$\mathrm{FM}$} & \multirow{2}{*}{\multicolumn{2}{|c|}{ 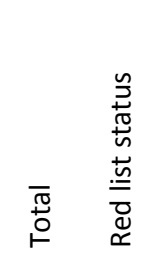 }} \\
\hline & 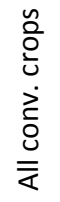 & $\frac{\mathbb{N}}{\frac{N}{\pi}}$ & 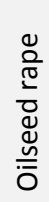 & $\frac{\vec{d}}{\frac{d}{\pi}}$ & 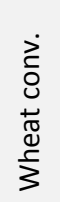 & 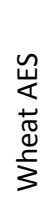 & 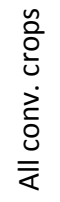 & $\frac{\stackrel{N}{N}}{\sum}$ & 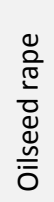 & $\frac{\vec{d}}{\frac{\vec{L}}{D}}$ & 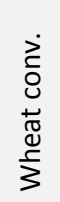 & 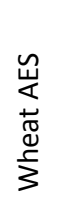 & & \\
\hline $\begin{array}{l}\text { Total number of plots } \\
(n)\end{array}$ & 40 & 10 & 10 & 10 & 10 & 10 & 40 & 10 & 10 & 10 & 10 & 10 & 100 & \\
\hline Centaurea cyanus & 1 & 0 & 0 & 0 & 1 & 2 & 1 & 0 & 0 & 0 & 1 & 2 & 6 & $*$ \\
\hline Centaurea jacea & 0 & 0 & 0 & 0 & 0 & 0 & 1 & 0 & 0 & 1 & 0 & 0 & 1 & $*$ \\
\hline Centaurea scabiosa & 0 & 0 & 0 & 0 & 0 & 0 & 0 & 0 & 0 & 0 & 0 & 4 & 4 & $*$ \\
\hline Centaurea stoebe & 0 & 0 & 0 & 0 & 0 & 0 & 0 & 0 & 0 & 0 & 0 & 1 & 1 & $*$ \\
\hline Cerastium holosteoides & 0 & 0 & 0 & 0 & 0 & 0 & 0 & 0 & 0 & 0 & 0 & 2 & 2 & $*$ \\
\hline Chenopodium album & 8 & 3 & 1 & 2 & 2 & 2 & 18 & 4 & 5 & 5 & 4 & 1 & 29 & $*$ \\
\hline $\begin{array}{l}\text { Chenopodium } \\
\text { hybridum }\end{array}$ & 1 & 1 & 0 & 0 & 0 & 1 & 3 & 2 & 1 & 0 & 0 & 0 & 5 & $*$ \\
\hline Cichorium intybus & 0 & 0 & 0 & 0 & 0 & 0 & 0 & 0 & 0 & 0 & 0 & 1 & 1 & $*$ \\
\hline Cirsium arvense & 4 & 1 & 1 & 2 & 0 & 7 & 22 & 7 & 5 & 7 & 3 & 10 & 43 & $*$ \\
\hline Cirsium vulgare & 0 & 0 & 0 & 0 & 0 & 0 & 3 & 0 & 1 & 1 & 1 & 0 & 3 & $*$ \\
\hline Consolida regalis & 0 & 0 & 0 & 0 & 0 & 7 & 2 & 0 & 0 & 2 & 0 & 7 & 16 & 3 \\
\hline Convolvulus arvensis & 9 & 2 & 4 & 3 & 0 & 7 & 28 & 6 & 8 & 6 & 8 & 10 & 54 & $*$ \\
\hline Cynoglossum officinale & 0 & 0 & 0 & 0 & 0 & 1 & 0 & 0 & 0 & 0 & 0 & 0 & 1 & $*$ \\
\hline Dactylis glomerata & 0 & 0 & 0 & 0 & 0 & 0 & 9 & 5 & 2 & 2 & 0 & 5 & 14 & $*$ \\
\hline Daucus carota & 0 & 0 & 0 & 0 & 0 & 0 & 2 & 0 & 0 & 1 & 1 & 4 & 6 & $*$ \\
\hline Descurainia sophia & 3 & 0 & 3 & 0 & 0 & 3 & 8 & 0 & 3 & 2 & 3 & 1 & 15 & $*$ \\
\hline Echinochloa crus-galli & 3 & 3 & 0 & 0 & 0 & 0 & 2 & 2 & 0 & 0 & 0 & 0 & 5 & $*$ \\
\hline Elymus repens & 4 & 1 & 2 & 0 & 1 & 2 & 30 & 6 & 9 & 6 & 9 & 2 & 38 & $*$ \\
\hline Epilobium ciliatum & 1 & 0 & 1 & 0 & 0 & 0 & 2 & 0 & 1 & 1 & 0 & 0 & 3 & $*$ \\
\hline Equisetum arvense & 3 & 1 & 1 & 0 & 1 & 0 & 8 & 1 & 3 & 2 & 2 & 0 & 11 & $*$ \\
\hline Erodium cicutarium & 0 & 0 & 0 & 0 & 0 & 2 & 2 & 0 & 0 & 1 & 1 & 3 & 7 & $*$ \\
\hline Eryngium campestre & 0 & 0 & 0 & 0 & 0 & 0 & 0 & 0 & 0 & 0 & 0 & 5 & 5 & $\mathrm{~V}$ \\
\hline Euphorbia cyparissias & 0 & 0 & 0 & 0 & 0 & 0 & 1 & 0 & 0 & 0 & 1 & 4 & 5 & $*$ \\
\hline Euphorbia esula & 0 & 0 & 0 & 0 & 0 & 0 & 0 & 0 & 0 & 0 & 0 & 1 & 1 & $*$ \\
\hline Euphorbia exigua & 0 & 0 & 0 & 0 & 0 & 4 & 0 & 0 & 0 & 0 & 0 & 6 & 10 & $*$ \\
\hline Euphorbia falcata & 0 & 0 & 0 & 0 & 0 & 0 & 0 & 0 & 0 & 0 & 0 & 1 & 1 & 1 \\
\hline Euphorbia helioscopia & 1 & 0 & 1 & 0 & 0 & 2 & 11 & 3 & 3 & 3 & 2 & 5 & 19 & $*$ \\
\hline Euphorbia platyphyllos & 0 & 0 & 0 & 0 & 0 & 1 & 1 & 0 & 0 & 0 & 1 & 3 & 5 & $*$ \\
\hline Falcaria vulgaris & 0 & 0 & 0 & 0 & 0 & 3 & 2 & 1 & 0 & 1 & 0 & 4 & 9 & $*$ \\
\hline Fallopia convolvulus & 21 & 7 & 3 & 5 & 6 & 7 & 28 & 6 & 7 & 8 & 7 & 6 & 62 & $*$ \\
\hline Festuca brevipila & 0 & 0 & 0 & 0 & 0 & 0 & 1 & 0 & 0 & 1 & 0 & 0 & 1 & $*$ \\
\hline Festuca pratensis & 0 & 0 & 0 & 0 & 0 & 0 & 3 & 0 & 2 & 1 & 0 & 1 & 4 & $*$ \\
\hline Festuca rubra agg. & 0 & 0 & 0 & 0 & 0 & 0 & 1 & 0 & 0 & 0 & 1 & 0 & 1 & $*$ \\
\hline Fumaria officinalis & 5 & 2 & 0 & 2 & 1 & 0 & 6 & 0 & 0 & 3 & 3 & 0 & 11 & $*$ \\
\hline Fumaria vaillantii & 1 & 0 & 0 & 1 & 0 & 1 & 4 & 2 & 0 & 1 & 1 & 0 & 6 & $*$ \\
\hline Galeopsis tetrahit & 0 & 0 & 0 & 0 & 0 & 0 & 1 & 0 & 0 & 0 & 1 & 0 & 1 & $*$ \\
\hline Galium album & 0 & 0 & 0 & 0 & 0 & 0 & 1 & 0 & 0 & 0 & 1 & 3 & 4 & $*$ \\
\hline Galium aparine & 16 & 3 & 4 & 3 & 6 & 6 & 35 & 7 & 10 & 8 & 10 & 4 & 61 & $*$ \\
\hline Galium glaucum & 0 & 0 & 0 & 0 & 0 & 0 & 0 & 0 & 0 & 0 & 0 & 1 & 1 & $\mathrm{~V}$ \\
\hline Galium spurium & 0 & 0 & 0 & 0 & 0 & 1 & 0 & 0 & 0 & 0 & 0 & 2 & 3 & $\mathrm{D}$ \\
\hline Galium tricornutum & 0 & 0 & 0 & 0 & 0 & 2 & 0 & 0 & 0 & 0 & 0 & 2 & 4 & 3 \\
\hline Galium verum & 0 & 0 & 0 & 0 & 0 & 0 & 0 & 0 & 0 & 0 & 0 & 1 & 1 & $*$ \\
\hline Geranium columbinum & 0 & 0 & 0 & 0 & 0 & 5 & 0 & 0 & 0 & 0 & 0 & 6 & 11 & $*$ \\
\hline Geranium dissectum & 5 & 3 & 1 & 1 & 0 & 4 & 18 & 8 & 5 & 2 & 3 & 4 & 31 & $*$ \\
\hline Geranium pusillum & 4 & 2 & 2 & 0 & 0 & 6 & 13 & 4 & 3 & 2 & 4 & 3 & 26 & $*$ \\
\hline Geum urbanum & 0 & 0 & 0 & 0 & 0 & 0 & 1 & 0 & 1 & 0 & 0 & 1 & 2 & $*$ \\
\hline Glechoma hederacea & 0 & 0 & 0 & 0 & 0 & 0 & 3 & 1 & 1 & 1 & 0 & 1 & 4 & $*$ \\
\hline $\begin{array}{l}\text { Heracleum } \\
\text { sphondylium }\end{array}$ & 0 & 0 & 0 & 0 & 0 & 0 & 1 & 1 & 0 & 0 & 0 & 0 & 1 & $*$ \\
\hline Hypericum perforatum & 0 & 0 & 0 & 0 & 0 & 0 & 0 & 0 & 0 & 0 & 0 & 2 & 2 & $*$ \\
\hline Knautia arvensis & 0 & 0 & 0 & 0 & 0 & 1 & 0 & 0 & 0 & 0 & 0 & 3 & 4 & $*$ \\
\hline Lactuca serriola & 0 & 0 & 0 & 0 & 0 & 0 & 1 & 0 & 1 & 0 & 0 & 2 & 3 & $*$ \\
\hline Lamium amplexicaule & 1 & 0 & 0 & 0 & 1 & 0 & 2 & 0 & 0 & 0 & 2 & 2 & 5 & $*$ \\
\hline Lamium purpureum & 4 & 1 & 0 & 2 & 1 & 1 & 10 & 2 & 2 & 1 & 5 & 2 & 17 & $*$ \\
\hline
\end{tabular}




\begin{tabular}{|c|c|c|c|c|c|c|c|c|c|c|c|c|c|c|}
\hline & \multicolumn{6}{|c|}{$\mathrm{FI}$} & \multicolumn{6}{|c|}{ FM } & \multirow{2}{*}{\multicolumn{2}{|c|}{ 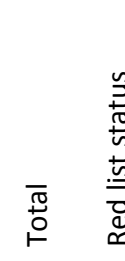 }} \\
\hline & 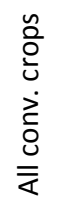 & 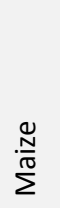 & 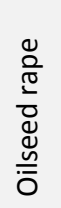 & $\frac{\sqrt{\frac{1}{2}}}{\frac{\pi}{\pi}}$ & 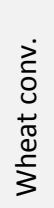 & 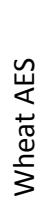 & 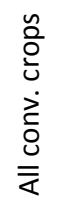 & $\frac{\stackrel{N}{N}}{\sum^{\pi}}$ & 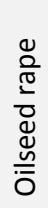 & $\frac{\vec{d}}{\frac{\pi}{\grave{D}}}$ & 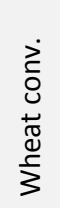 & 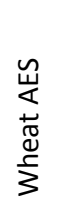 & & \\
\hline $\begin{array}{l}\text { Total number of plots } \\
(n)\end{array}$ & 40 & 10 & 10 & 10 & 10 & 10 & 40 & 10 & 10 & 10 & 10 & 10 & 100 & \\
\hline Lappula squarrosa & 0 & 0 & 0 & 0 & 0 & 0 & 0 & 0 & 0 & 0 & 0 & 1 & 1 & $*$ \\
\hline Lapsana communis & 1 & 0 & 0 & 1 & 0 & 4 & 0 & 0 & 0 & 0 & 0 & 4 & 9 & $*$ \\
\hline Lathyrus tuberosus & 1 & 1 & 0 & 0 & 0 & 2 & 3 & 1 & 1 & 1 & 0 & 5 & 11 & $*$ \\
\hline Lepidium campestre & 0 & 0 & 0 & 0 & 0 & 1 & 0 & 0 & 0 & 0 & 0 & 3 & 4 & $*$ \\
\hline Lepidium draba & 0 & 0 & 0 & 0 & 0 & 1 & 1 & 0 & 0 & 1 & 0 & 2 & 4 & $*$ \\
\hline Linum austriacum & 0 & 0 & 0 & 0 & 0 & 0 & 0 & 0 & 0 & 0 & 0 & 3 & 3 & $*$ \\
\hline Lolium perenne & 0 & 0 & 0 & 0 & 0 & 0 & 1 & 1 & 0 & 0 & 0 & 0 & 1 & $*$ \\
\hline Lotus corniculatus & 0 & 0 & 0 & 0 & 0 & 0 & 0 & 0 & 0 & 0 & 0 & 1 & 1 & $*$ \\
\hline Matricaria recutita & 2 & 0 & 0 & 2 & 0 & 1 & 7 & 1 & 2 & 4 & 0 & 0 & 10 & $*$ \\
\hline Medicago lupulina & 0 & 0 & 0 & 0 & 0 & 3 & 0 & 0 & 0 & 0 & 0 & 5 & 8 & $*$ \\
\hline $\begin{array}{l}\text { Microthlaspi } \\
\text { perfoliatum }\end{array}$ & 0 & 0 & 0 & 0 & 0 & 0 & 0 & 0 & 0 & 0 & 0 & 1 & 1 & $*$ \\
\hline Myosotis arvensis & 6 & 1 & 3 & 1 & 1 & 3 & 11 & 1 & 6 & 1 & 3 & 3 & 23 & $*$ \\
\hline Nonea erecta & 0 & 0 & 0 & 0 & 0 & 0 & 0 & 0 & 0 & 0 & 0 & 1 & 1 & $*$ \\
\hline Ononis spinosa & 0 & 0 & 0 & 0 & 0 & 0 & 0 & 0 & 0 & 0 & 0 & 1 & 1 & $*$ \\
\hline Onopordum acanthium & 0 & 0 & 0 & 0 & 0 & 1 & 0 & 0 & 0 & 0 & 0 & 0 & 1 & $*$ \\
\hline Papaver argemone & 0 & 0 & 0 & 0 & 0 & 0 & 0 & 0 & 0 & 0 & 0 & 2 & 2 & $*$ \\
\hline Papaver rhoeas & 2 & 0 & 2 & 0 & 0 & 7 & 15 & 1 & 5 & 5 & 4 & 4 & 28 & $*$ \\
\hline Persicaria lapathifolia & 2 & 2 & 0 & 0 & 0 & 0 & 2 & 2 & 0 & 0 & 0 & 0 & 4 & $*$ \\
\hline Plantago lanceolata & 0 & 0 & 0 & 0 & 0 & 0 & 0 & 0 & 0 & 0 & 0 & 2 & 2 & $*$ \\
\hline Poa annua & 1 & 0 & 1 & 0 & 0 & 0 & 1 & 0 & 0 & 0 & 1 & 0 & 2 & $*$ \\
\hline Poa pratensis & 0 & 0 & 0 & 0 & 0 & 0 & 5 & 0 & 3 & 2 & 0 & 0 & 5 & $*$ \\
\hline Poa trivialis & 0 & 0 & 0 & 0 & 0 & 0 & 6 & 0 & 3 & 3 & 0 & 4 & 10 & $*$ \\
\hline Polygonum aviculare & 14 & 6 & 4 & 3 & 1 & 5 & 24 & 8 & 4 & 7 & 5 & 5 & 48 & $*$ \\
\hline Potentilla anserina & 0 & 0 & 0 & 0 & 0 & 0 & 1 & 1 & 0 & 0 & 0 & 0 & 1 & $*$ \\
\hline Potentilla reptans & 0 & 0 & 0 & 0 & 0 & 0 & 3 & 2 & 0 & 0 & 1 & 3 & 6 & $*$ \\
\hline Ranunculus arvensis & 0 & 0 & 0 & 0 & 0 & 1 & 0 & 0 & 0 & 0 & 0 & 1 & 2 & 3 \\
\hline Ranunculus repens & 0 & 0 & 0 & 0 & 0 & 2 & 1 & 0 & 1 & 0 & 0 & 2 & 5 & $*$ \\
\hline Reseda lutea & 0 & 0 & 0 & 0 & 0 & 0 & 0 & 0 & 0 & 0 & 0 & 3 & 3 & $*$ \\
\hline Rumex crispus & 1 & 1 & 0 & 0 & 0 & 3 & 7 & 2 & 3 & 1 & 1 & 1 & 12 & $*$ \\
\hline Rumex obtusifolius & 0 & 0 & 0 & 0 & 0 & 1 & 1 & 1 & 0 & 0 & 0 & 0 & 2 & $*$ \\
\hline Sanguisorba minor & 0 & 0 & 0 & 0 & 0 & 0 & 0 & 0 & 0 & 0 & 0 & 3 & 3 & $*$ \\
\hline Senecio vulgaris & 0 & 0 & 0 & 0 & 0 & 0 & 1 & 1 & 0 & 0 & 0 & 0 & 1 & $*$ \\
\hline Sherardia arvensis & 0 & 0 & 0 & 0 & 0 & 0 & 0 & 0 & 0 & 0 & 0 & 1 & 1 & $*$ \\
\hline Silene latifolia ssp. alba & 0 & 0 & 0 & 0 & 0 & 0 & 3 & 0 & 1 & 0 & 2 & 1 & 4 & $*$ \\
\hline Silene noctiflora & 1 & 1 & 0 & 0 & 0 & 0 & 1 & 1 & 0 & 0 & 0 & 1 & 3 & $\mathrm{~V}$ \\
\hline Silene vulgaris & 0 & 0 & 0 & 0 & 0 & 0 & 0 & 0 & 0 & 0 & 0 & 1 & 1 & $*$ \\
\hline Sinapis arvensis & 0 & 0 & 0 & 0 & 0 & 1 & 1 & 0 & 1 & 0 & 0 & 2 & 4 & $*$ \\
\hline Sisymbrium officinale & 2 & 1 & 0 & 1 & 0 & 0 & 2 & 0 & 1 & 1 & 0 & 0 & 4 & $*$ \\
\hline Solanum nigrum & 3 & 3 & 0 & 0 & 0 & 0 & 3 & 3 & 0 & 0 & 0 & 0 & 6 & $*$ \\
\hline Sonchus arvensis & 0 & 0 & 0 & 0 & 0 & 0 & 2 & 1 & 0 & 1 & 0 & 0 & 2 & $*$ \\
\hline Sonchus asper & 0 & 0 & 0 & 0 & 0 & 1 & 3 & 0 & 3 & 0 & 0 & 1 & 5 & $*$ \\
\hline Stachys palustris & 0 & 0 & 0 & 0 & 0 & 0 & 0 & 0 & 0 & 0 & 0 & 1 & 1 & $*$ \\
\hline Stellaria media & 1 & 0 & 0 & 1 & 0 & 3 & 6 & 3 & 1 & 1 & 1 & 1 & 11 & $*$ \\
\hline Thlaspi arvense & 4 & 0 & 2 & 2 & 0 & 1 & 10 & 1 & 3 & 5 & 1 & 2 & 17 & $*$ \\
\hline Trifolium campestre & 0 & 0 & 0 & 0 & 0 & 0 & 0 & 0 & 0 & 0 & 0 & 1 & 1 & $*$ \\
\hline Trifolium pratense & 0 & 0 & 0 & 0 & 0 & 1 & 0 & 0 & 0 & 0 & 0 & 1 & 2 & $*$ \\
\hline Trifolium repens & 1 & 1 & 0 & 0 & 0 & 0 & 1 & 0 & 0 & 1 & 0 & 0 & 2 & $*$ \\
\hline $\begin{array}{l}\text { Tripleurospermum } \\
\text { perforatum }\end{array}$ & 4 & 1 & 2 & 0 & 1 & 7 & 15 & 3 & 5 & 3 & 4 & 5 & 31 & 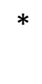 \\
\hline Urtica dioica & 1 & 0 & 1 & 0 & 0 & 0 & 10 & 3 & 2 & 1 & 4 & 0 & 11 & $*$ \\
\hline Urtica urens & 0 & 0 & 0 & 0 & 0 & 0 & 1 & 1 & 0 & 0 & 0 & 0 & 1 & $*$ \\
\hline Valerianella dentata & 0 & 0 & 0 & 0 & 0 & 4 & 0 & 0 & 0 & 0 & 0 & 5 & 9 & V \\
\hline Valerianella locusta & 0 & 0 & 0 & 0 & 0 & 0 & 1 & 0 & 0 & 0 & 1 & 0 & 1 & $*$ \\
\hline Veronica arvensis & 0 & 0 & 0 & 0 & 0 & 3 & 0 & 0 & 0 & 0 & 0 & 4 & 7 & $*$ \\
\hline
\end{tabular}




\begin{tabular}{|c|c|c|c|c|c|c|c|c|c|c|c|c|c|c|}
\hline & \multicolumn{6}{|c|}{$\mathrm{FI}$} & \multicolumn{6}{|c|}{$\mathrm{FM}$} & \multirow{2}{*}{\multicolumn{2}{|c|}{ 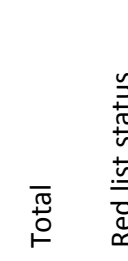 }} \\
\hline & 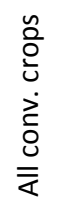 & 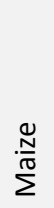 & 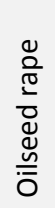 & 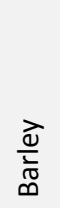 & 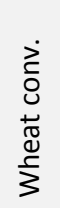 & 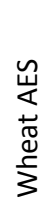 & 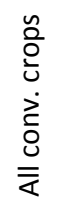 & 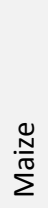 & 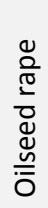 & $\frac{\vec{d}}{\frac{d}{\pi}}$ & 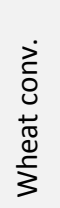 & 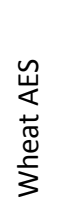 & & \\
\hline $\begin{array}{l}\text { Total number of plots } \\
(n)\end{array}$ & 40 & 10 & 10 & 10 & 10 & 10 & 40 & 10 & 10 & 10 & 10 & 10 & 100 & \\
\hline Veronica hederifolia & 2 & 0 & 1 & 1 & 0 & 0 & 6 & 0 & 0 & 3 & 3 & 1 & 9 & $*$ \\
\hline Veronica persica & 5 & 4 & 1 & 0 & 0 & 6 & 18 & 8 & 5 & 2 & 3 & 6 & 35 & * \\
\hline Veronica polita & 1 & 1 & 0 & 0 & 0 & 3 & 4 & 3 & 0 & 0 & 1 & 5 & 13 & $*$ \\
\hline Vicia angustifolia & 0 & 0 & 0 & 0 & 0 & 1 & 0 & 0 & 0 & 0 & 0 & 6 & 7 & * \\
\hline Vicia cracca agg. & 0 & 0 & 0 & 0 & 0 & 0 & 0 & 0 & 0 & 0 & 0 & 1 & 1 & $*$ \\
\hline Vicia hirsuta & 0 & 0 & 0 & 0 & 0 & 2 & 0 & 0 & 0 & 0 & 0 & 2 & 4 & $*$ \\
\hline Vicia sativa & 0 & 0 & 0 & 0 & 0 & 4 & 1 & 1 & 0 & 0 & 0 & 4 & 9 & $*$ \\
\hline Vicia villosa & 0 & 0 & 0 & 0 & 0 & 0 & 0 & 0 & 0 & 0 & 0 & 1 & 1 & $*$ \\
\hline Viola arvensis & 14 & 4 & 7 & 1 & 2 & 7 & 18 & 3 & 6 & 4 & 5 & 8 & 47 & $*$ \\
\hline Vulpia myuros & 0 & 0 & 0 & 0 & 0 & 0 & 1 & 0 & 0 & 1 & 0 & 0 & 1 & $*$ \\
\hline \multicolumn{15}{|c|}{ Cases excluded from the analyses as specimens were not identifiable to the required level: } \\
\hline Anagallis sp. & 1 & 0 & 0 & 1 & 0 & 0 & 0 & 0 & 0 & 0 & 0 & 0 & 1 & na \\
\hline Arctium sp. & 1 & 0 & 1 & 0 & 0 & 0 & 6 & 0 & 2 & 0 & 4 & 0 & 7 & na \\
\hline Fumaria sp. & 0 & 0 & 0 & 0 & 0 & 0 & 1 & 0 & 0 & 1 & 0 & 0 & 1 & na \\
\hline Rumex sp. & 1 & 0 & 0 & 1 & 0 & 2 & 1 & 1 & 0 & 0 & 0 & 0 & 4 & na \\
\hline Sonchus sp. & 1 & 0 & 0 & 1 & 0 & 0 & 1 & 0 & 0 & 1 & 0 & 0 & 2 & na \\
\hline Taraxacum sp. & 2 & 1 & 0 & 0 & 1 & 2 & 3 & 0 & 1 & 1 & 1 & 6 & 13 & na \\
\hline Trifolium sp. & 0 & 0 & 0 & 0 & 0 & 0 & 0 & 0 & 0 & 0 & 0 & 1 & 1 & na \\
\hline Asteracea sp. & 0 & 0 & 0 & 0 & 0 & 0 & 3 & 1 & 2 & 0 & 0 & 0 & 3 & na \\
\hline Caryophyllaceae sp. & 0 & 0 & 0 & 0 & 0 & 0 & 1 & 0 & 0 & 1 & 0 & 0 & 1 & na \\
\hline Poaceae sp. & 0 & 0 & 0 & 0 & 0 & 0 & 1 & 0 & 1 & 0 & 0 & 0 & 1 & na \\
\hline
\end{tabular}


Appendix 3.B Mean TPAR ( \pm SE) measured in the field interior (FI) and at the field margins (FM) of 50 arable fields with different cropping systems in two study regions in the Central Uplands of Germany (LS, Lower Saxon hills; TB, Thuringian Basin). Differences in TPAR between the study areas for each cropping system and in-field position of the plot were tested with the independent twogroup Mann-Whitney $U$ test $(*, p \leq 0.05 ; * *, p \leq 0.01)$.

\begin{tabular}{lccccccc}
\hline & & & \multicolumn{2}{c}{ TPAR (\%) } & FM & \\
\hline Data set & $\begin{array}{c}\boldsymbol{n} \text { per } \\
\text { location }\end{array}$ & LS & TB & $\boldsymbol{P}$ & LS & TB & $\boldsymbol{P}$ \\
\hline All conv. crops & 20 & $9.1 \pm 1.1$ & $10.6 \pm 0.9$ & 0.29 & $15.8 \pm 2.2$ & $18.0 \pm 1.5$ & 0.13 \\
Maize & 5 & $5.7 \pm 1.3$ & $6.1 \pm 1.1$ & 0.84 & $8.8 \pm 1.1$ & $13.1 \pm 2.4$ & 0.10 \\
Oilseed rape & 5 & $12.2 \pm 1.8$ & $12.8 \pm 1.1$ & 0.55 & $16.3 \pm 3.2$ & $22.3 \pm 2.5$ & 0.31 \\
Barley & 5 & $10.2 \pm 2.9$ & $11.4 \pm 1.7$ & 1.00 & $21.1 \pm 5.0$ & $17.0 \pm 1.3$ & 0.70 \\
Wheat conv. & 5 & $8.2 \pm 2.1$ & $12.2 \pm 2.0$ & 0.22 & $17.0 \pm 6.0$ & $19.4 \pm 4.3$ & 0.70 \\
Wheat AES & 5 & $\mathbf{4 6 . 0 \pm 4 . 1}$ & $\mathbf{6 7 . 7} \pm \mathbf{5 . 6}$ & $\mathbf{0 . 0 2}^{*}$ & $\mathbf{5 2 . 8} \pm \mathbf{4 . 8}$ & $\mathbf{8 5 . 3 \pm 3 . 7}$ & $\mathbf{0 . 0 1}^{* *}$ \\
\hline
\end{tabular}


Appendix 3.C Means ( \pm SE) of TPAR (in \%), the crop cover, the weed cover and the total cover (= crop + weed cover, all in $\%)$ and the mean number of species in arable weed assemblages for four different conventionally managed crops (conv.) and winter wheat managed under an agri-environmental scheme (AES) from arable fields in the Central Uplands of Germany. As TPAR of AES fields was found to differ between the two study regions (LS: Lower Saxon hills, TB:

Thuringian Basin), means are also given for each region. Capital letters indicate significant differences between cropping systems (grey shaded rows,

nonparametric Behrens-Fisher test for multiple comparisons). Values from the field margin (FM) are significantly different from the field interior (FI) across cropping systems (grey shaded rows) for all six parameters (Wilcoxon signed-rank test; $n=50 ; *, p \leq 0.05 ; * * *, p \leq 0.001$ ).

\begin{tabular}{|c|c|c|c|c|c|c|c|c|c|}
\hline \multirow[b]{2}{*}{ Position } & \multirow[t]{2}{*}{$\begin{array}{c}\text { n per } \\
\text { column }\end{array}$} & \multicolumn{2}{|c|}{$\operatorname{TPAR}(\%)$} & \multicolumn{2}{|c|}{ Crop cover (\%) } & \multicolumn{2}{|c|}{ Weed cover $(\%)$} & \multicolumn{2}{|c|}{ Species no. } \\
\hline & & $* * *$ & FM & FI & FM & $* * *$ & FM & $* * *$ & FM \\
\hline All conv. crops & 40 & $9.9 \pm 0.7$ & $16.9 \pm 1.3$ & $78.2 \pm 4.9$ & $60.9 \pm 6.2$ & $2.5 \pm 2.1$ & $16.1 \pm 3.4$ & $4.6 \pm 0.6$ & $13.9 \pm 0.8$ \\
\hline Maize & 10 & $5.9 \pm 0.8^{\mathrm{A}}$ & $10.9 \pm 1.4^{\mathrm{A}}$ & $80.0 \pm 3.7^{\mathrm{A}}$ & $64.6 \pm 3.4^{\mathrm{A}}$ & $3.5 \pm 1.3^{\mathrm{A}}$ & $20.6 \pm 4.2^{\mathrm{A}}$ & $6.1 \pm 1.4^{\mathrm{A}}$ & $13.1 \pm 1.4^{\mathrm{A}}$ \\
\hline Oilseed rape & 10 & $12.6 \pm 1.0^{\mathrm{B}}$ & $19.3 \pm 2.2^{\mathrm{B}}$ & $93.6 \pm 1.8^{\mathrm{B}}$ & $81.0 \pm 3.8^{\mathrm{B}}$ & $1.7 \pm 0.5^{\mathrm{A}}$ & $13.7 \pm 4.4^{\mathrm{A}}$ & $5.1 \pm 0.6^{\mathrm{A}}$ & $15.0 \pm 1.3^{\mathrm{A}}$ \\
\hline Barley & 10 & $10.8 \pm 1.6^{\mathrm{AB}}$ & $19.1 \pm 2.5^{\mathrm{B}}$ & $66.0 \pm 5.3^{\mathrm{A}}$ & $45.0 \pm 5.1^{\mathrm{C}}$ & $0.5 \pm 0.3^{\mathrm{A}}$ & $13.5 \pm 3.2^{\mathrm{A}}$ & $4.1 \pm 1.6^{\mathrm{A}}$ & $13.5 \pm 1.9^{\mathrm{A}}$ \\
\hline Wheat conv. & 10 & $10.2 \pm 1.5^{\mathrm{AB}}$ & $18.2 \pm 3.5^{\mathrm{AB}}$ & $73.1 \pm 3.4^{\mathrm{A}}$ & $53.0 \pm 5.6^{\mathrm{AC}}$ & $4.3 \pm 4.0^{\mathrm{A}}$ & $16.7 \pm 3.8^{\mathrm{A}}$ & $3.1 \pm 0.7^{\mathrm{A}}$ & $14.0 \pm 2.1^{\mathrm{A}}$ \\
\hline Wheat AES & 10 & $56.9 \pm 4.9^{C}$ & $69.1 \pm 6.1^{\mathrm{C}}$ & $23.2 \pm 5.9^{C}$ & $10.3 \pm 4.1^{\mathrm{D}}$ & $37.6 \pm 8.5^{\mathrm{B}}$ & $27.9 \pm 7.6^{\mathrm{A}}$ & $21.1 \pm 2.0^{\mathrm{B}}$ & $32.5 \pm 2.4^{\mathrm{B}}$ \\
\hline Wheat AES (LS) & 5 & $46.0 \pm 4.1$ & $52.8 \pm 4.8$ & $14.4 \pm 3.1$ & $7.0 \pm 1.7$ & $27.2 \pm 13.7$ & $35.1 \pm 13.3$ & $22.4 \pm 2.0$ & $37.4 \pm 3.0$ \\
\hline Wheat AES (TB) & 5 & $67.7 \pm 5.6$ & $85.3 \pm 3.7$ & $32.0 \pm 10.3$ & $13.5 \pm 8.1$ & $48.0 \pm 9.2$ & $20.6 \pm 7.5$ & $19.8 \pm 3.5$ & $27.6 \pm 2.1$ \\
\hline
\end{tabular}


Appendix 4.A List of species recorded on SRCs in the Thuringian Basin and in the Lower Saxon hills giving the naturalisation status, the habitat preference, the life form according to Raunkiær and the number of SRCs in which each species was recorded according to the position of the plot (In interior; $E d$ edge), the plantation age (in yrs.), the survey season ( $S p$ spring; $S u$ summer) and the tree species ( $P$ poplar; $W$ willow). Naturarlisation status: Arch. archaeophyte, $n e o p h$. neophyte; habitat preferences: $G$ grassland, $A$ arable land, $N$ nitrophilous vegetation, $F$ forest, Gen. habitat generalists, life forms: Hemicryp. hemicryptophyte, theroph. therophyte, chamaeph. chamaephyte, phaneroph. phanerophyte). See chapter 4 for details on the assignment of the species to the different categories.

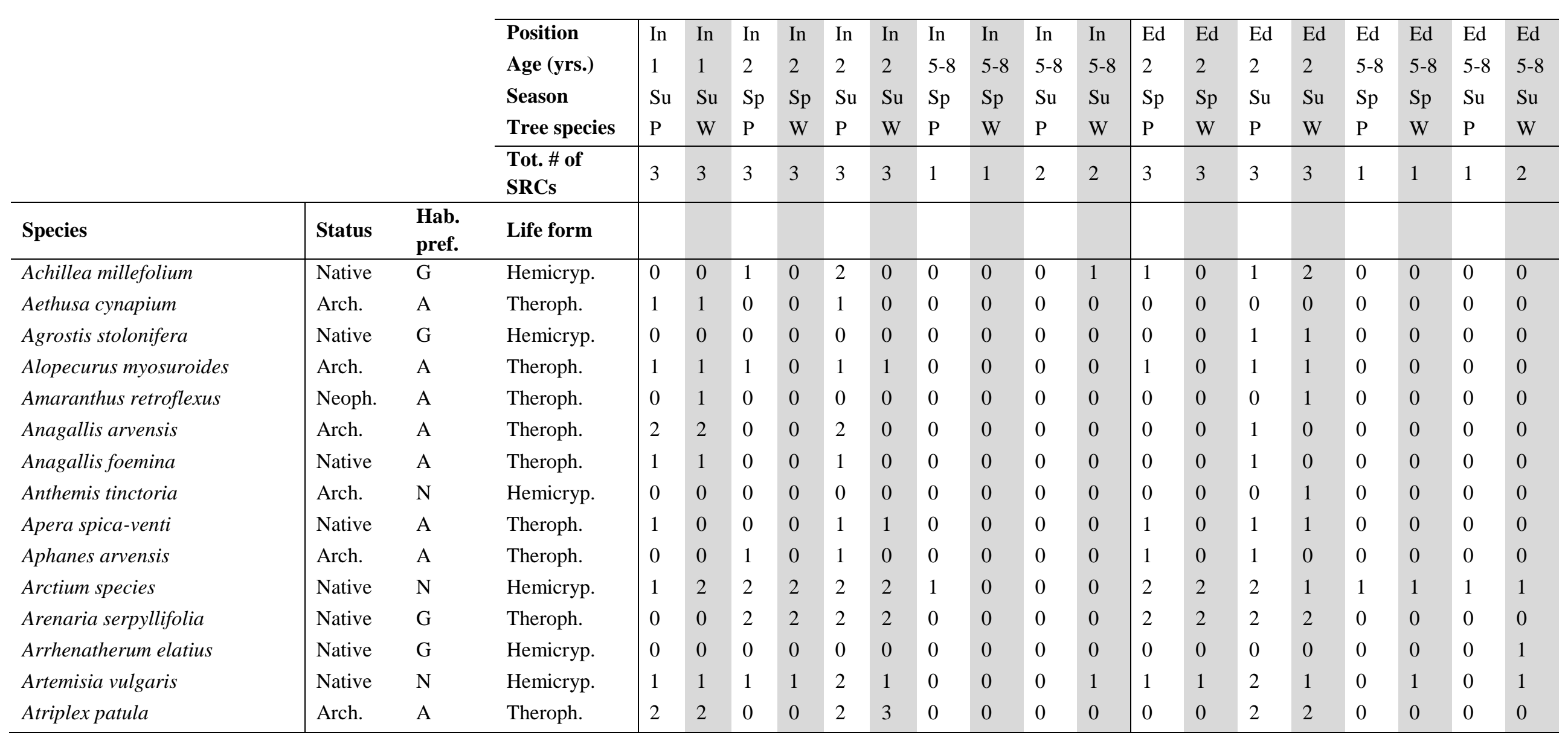




\begin{tabular}{|c|c|c|c|c|c|c|c|c|c|c|c|c|c|c|c|c|c|c|c|c|c|}
\hline & & & \multirow{5}{*}{$\begin{array}{l}\text { Position } \\
\text { Age (yrs.) } \\
\text { Season } \\
\text { Tree species }\end{array}$} & \multirow{5}{*}{\multicolumn{2}{|c|}{$\begin{array}{ll}\text { In } & \text { In } \\
1 & 1 \\
\mathrm{Su} & \mathrm{Su} \\
\mathrm{P} & \mathrm{W}\end{array}$}} & \multirow{5}{*}{$\begin{array}{l}\text { In } \\
2 \\
\mathrm{Sp} \\
\mathrm{P}\end{array}$} & \multirow{5}{*}{$\begin{array}{l}\text { In } \\
2 \\
\mathrm{Sp} \\
\mathrm{W}\end{array}$} & \multirow{5}{*}{$\begin{array}{l}\mathrm{In} \\
2 \\
\mathrm{Su} \\
\mathrm{P}\end{array}$} & \multirow{5}{*}{$\begin{array}{l}\text { In } \\
2 \\
\mathrm{Su} \\
\mathrm{W}\end{array}$} & \multirow{5}{*}{$\begin{array}{l}\text { In } \\
5-8 \\
\mathrm{Sp} \\
\mathrm{P}\end{array}$} & \multirow{5}{*}{$\begin{array}{l}\text { In } \\
5-8 \\
\text { Sp } \\
\text { W }\end{array}$} & \multirow{5}{*}{$\begin{array}{l}\mathrm{In} \\
5-8 \\
\mathrm{Su} \\
\mathrm{P}\end{array}$} & \multirow{5}{*}{$\begin{array}{l}\text { In } \\
5-8 \\
\mathrm{Su} \\
\mathrm{W}\end{array}$} & \multirow{5}{*}{\begin{tabular}{|l|}
$\mathrm{Ed}$ \\
2 \\
$\mathrm{Sp}$ \\
$\mathrm{P}$
\end{tabular}} & \multirow{5}{*}{$\begin{array}{l}\text { Ed } \\
2 \\
\text { Sp } \\
\text { W }\end{array}$} & \multirow{5}{*}{$\begin{array}{l}\mathrm{Ed} \\
2 \\
\mathrm{Su} \\
\mathrm{P}\end{array}$} & \multirow{5}{*}{$\begin{array}{l}\mathrm{Ed} \\
2 \\
\mathrm{Su} \\
\mathrm{W}\end{array}$} & \multirow{5}{*}{$\begin{array}{l}\mathrm{Ed} \\
5-8 \\
\mathrm{Sp} \\
\mathrm{P}\end{array}$} & \multirow{5}{*}{$\begin{array}{l}\text { Ed } \\
5-8 \\
\text { Sp } \\
W\end{array}$} & \multirow{5}{*}{$\begin{array}{l}\mathrm{Ed} \\
5-8 \\
\mathrm{Su} \\
\mathrm{P}\end{array}$} & \multirow{5}{*}{$\begin{array}{l}\mathrm{Ed} \\
5-8 \\
\mathrm{Su} \\
\mathrm{W}\end{array}$} \\
\hline & & & & & & & & & & & & & & & & & & & & & \\
\hline & & & & & & & & & & & & & & & & & & & & & \\
\hline & & & & & & & & & & & & & & & & & & & & & \\
\hline & & & & & & & & & & & & & & & & & & & & & \\
\hline & & & $\begin{array}{l}\text { Tot. \# of } \\
\text { SRCs }\end{array}$ & 3 & 3 & 3 & 3 & 3 & 3 & 1 & 1 & 2 & 2 & 3 & 3 & 3 & 3 & 1 & 1 & 1 & 2 \\
\hline Species & Status & $\begin{array}{l}\text { Hab. } \\
\text { pref. }\end{array}$ & Life form & & & & & & & & & & & & & & & & & & \\
\hline Avena fatua & Arch. & $\mathrm{N}$ & Theroph. & 1 & 2 & 0 & 0 & 1 & 1 & 0 & 0 & 0 & 0 & 0 & 0 & 1 & 2 & 0 & 0 & 0 & 0 \\
\hline Ballota nigra & Arch. & $\mathrm{N}$ & Chamaeph. & 1 & 1 & 1 & 1 & 2 & 1 & 0 & 0 & 0 & 0 & 2 & 2 & 2 & 2 & 0 & 0 & 0 & 1 \\
\hline Bellis perennis & Arch. & $\mathrm{G}$ & Hemicryp. & 0 & 0 & 3 & 0 & 0 & 0 & 0 & 0 & 0 & 0 & 0 & 0 & 0 & 0 & 0 & 0 & 0 & 0 \\
\hline Bromus hordeaceus & Native & $\mathrm{G}$ & Theroph. & 0 & 0 & 0 & 0 & 1 & 0 & 0 & 0 & 0 & 0 & 0 & 0 & 0 & 0 & 0 & 0 & 0 & 0 \\
\hline Bromus secalinus & Arch. & $\mathrm{A}$ & Theroph. & 0 & 0 & 0 & 0 & 0 & 0 & 0 & 0 & 0 & 0 & 0 & 0 & 0 & 1 & 0 & 0 & 0 & 0 \\
\hline Bromus sterilis & Arch. & A & Theroph. & 1 & 0 & 2 & 3 & 3 & 3 & 0 & 0 & 0 & 0 & 3 & 3 & 3 & 2 & 0 & 0 & 0 & 0 \\
\hline Calamagrostis epigejos & Native & G & Geophyte & 0 & 0 & 0 & 0 & 0 & 0 & 0 & 0 & 0 & 1 & 0 & 0 & 0 & 0 & 0 & 0 & 0 & 0 \\
\hline Calystegia sepium & Native & $\mathrm{N}$ & Geophyte & 0 & 0 & 0 & 0 & 0 & 0 & 0 & 0 & 1 & 1 & 0 & 0 & 0 & 0 & 0 & 0 & 0 & 1 \\
\hline Capsella bursa-pastoris & Native & A & Theroph. & 0 & 1 & 3 & 3 & 2 & 2 & 0 & 0 & 0 & 0 & 3 & 3 & 3 & 3 & 0 & 0 & 0 & 0 \\
\hline Carduus acanthoides & Arch. & $\mathrm{N}$ & Hemicryp. & 1 & 2 & 1 & 1 & 1 & 2 & 0 & 0 & 0 & 0 & 1 & 1 & 1 & 1 & 0 & 0 & 0 & 0 \\
\hline Centaurea cyanus & Arch. & A & Theroph. & 1 & 0 & 1 & 0 & 1 & 1 & 0 & 0 & 0 & 0 & 1 & 0 & 1 & 1 & 0 & 0 & 0 & 0 \\
\hline Chenopodiaceae species & Arch. & $\mathrm{A}$ & Theroph. & 0 & 0 & 1 & 1 & 0 & 0 & 0 & 0 & 0 & 0 & 3 & 1 & 0 & 0 & 0 & 0 & 0 & 0 \\
\hline Chenopodium album & Arch. & A & Theroph. & 3 & 3 & 2 & 2 & 3 & 3 & 0 & 0 & 0 & 0 & 2 & 1 & 3 & 3 & 0 & 0 & 0 & 0 \\
\hline Chenopodium hybridum & Arch. & $\mathrm{A}$ & Theroph. & 1 & 0 & 0 & 0 & 0 & 0 & 0 & 0 & 0 & 0 & 0 & 0 & 0 & 0 & 0 & 0 & 0 & 0 \\
\hline Cirsium arvense & Native & Gen. & Geophyte & 2 & 3 & 3 & 3 & 3 & 3 & 0 & 0 & 1 & 2 & 3 & 3 & 3 & 3 & 1 & 1 & 1 & 2 \\
\hline Cirsium vulgare & Native & $\mathrm{N}$ & Hemicryp. & 2 & 0 & 2 & 2 & 3 & 2 & 0 & 0 & 0 & 0 & 3 & 3 & 2 & 2 & 0 & 0 & 0 & 1 \\
\hline Convolvulus arvensis & Native & A & Geophyte & 1 & 1 & 0 & 1 & 1 & 2 & 0 & 0 & 0 & 2 & 1 & 1 & 1 & 2 & 0 & 0 & 0 & 2 \\
\hline Crepis biennis & Arch. & G & Hemicryp. & 0 & 0 & 0 & 0 & 0 & 0 & 0 & 0 & 0 & 0 & 0 & 0 & 0 & 1 & 0 & 0 & 0 & 0 \\
\hline Dactylis glomerata & Native & $\mathrm{N}$ & Hemicryp. & 0 & 0 & 1 & 0 & 0 & 0 & 0 & 0 & 0 & 0 & 2 & 2 & 1 & 1 & 0 & 0 & 0 & 2 \\
\hline Daucus carota & Native & Gen. & Hemicryp. & 0 & 0 & 1 & 1 & 1 & 1 & 0 & 0 & 0 & 0 & 2 & 2 & 0 & 0 & 0 & 1 & 0 & 0 \\
\hline Descurainia sophia & Arch. & A & Theroph. & 1 & 1 & 2 & 2 & 2 & 2 & 0 & 0 & 0 & 0 & 2 & 2 & 2 & 2 & 0 & 0 & 0 & 0 \\
\hline Dipsacus fullonum & Arch. & $\mathrm{N}$ & Hemicryp. & 0 & 1 & 0 & 1 & 0 & 1 & 0 & 0 & 0 & 0 & 1 & 1 & 1 & 1 & 0 & 0 & 0 & 0 \\
\hline
\end{tabular}




\begin{tabular}{|c|c|c|c|c|c|c|c|c|c|c|c|c|c|c|c|c|c|c|c|c|c|}
\hline & & & & & & & & & & & & & & & & & & & & & \\
\hline & & & Position & In & In & In & In & In & In & In & In & In & In & Ed & $\mathrm{Ed}$ & Ed & Ed & Ed & $\mathrm{Ed}$ & Ed & Ed \\
\hline & & & Age (yrs.) & 1 & 1 & 2 & 2 & 2 & 2 & $5-8$ & $5-8$ & $5-8$ & $5-8$ & 2 & 2 & 2 & 2 & $5-8$ & $5-8$ & $5-8$ & $5-8$ \\
\hline & & & Season & $\mathrm{Su}$ & $\mathrm{Su}$ & $\mathrm{Sp}$ & $\mathrm{Sp}$ & $\mathrm{Su}$ & $\mathrm{Su}$ & $\mathrm{Sp}$ & $\mathrm{Sp}$ & $\mathrm{Su}$ & $\mathrm{Su}$ & $\mathrm{Sp}$ & $\mathrm{Sp}$ & $\mathrm{Su}$ & $\mathrm{Su}$ & $\mathrm{Sp}$ & $\mathrm{Sp}$ & $\mathrm{Su}$ & $\mathrm{Su}$ \\
\hline & & & Tree species & $\mathrm{P}$ & $\mathrm{W}$ & $\mathrm{P}$ & $\mathrm{W}$ & $\mathrm{P}$ & $\mathrm{W}$ & $\mathrm{P}$ & $\mathrm{W}$ & $\mathrm{P}$ & $\mathrm{W}$ & $\mathrm{P}$ & $\mathrm{W}$ & $\mathrm{P}$ & $\mathrm{W}$ & $\mathrm{P}$ & $\mathrm{W}$ & $\mathrm{P}$ & $\mathrm{W}$ \\
\hline & & & $\begin{array}{l}\text { Tot. \# of } \\
\text { SRCs }\end{array}$ & 3 & 3 & 3 & 3 & 3 & 3 & 1 & 1 & 2 & 2 & 3 & 3 & 3 & 3 & 1 & 1 & 1 & 2 \\
\hline Species & Status & $\begin{array}{l}\text { Hab. } \\
\text { pref. }\end{array}$ & Life form & & & & & & & & & & & & & & & & & & \\
\hline Elymus repens & Native & $\mathrm{N}$ & Geophyte & 2 & 2 & 3 & 3 & 2 & 2 & 0 & 1 & 2 & 2 & 3 & 3 & 3 & 2 & 1 & 1 & 1 & 2 \\
\hline Epilobium ciliatum & Neoph. & $\mathrm{N}$ & Hemicryp. & 0 & 0 & 0 & 0 & 1 & 0 & 0 & 0 & 0 & 0 & 0 & 0 & 0 & 0 & 0 & 0 & 0 & 0 \\
\hline Epilobium lamyi & Native & $\mathrm{N}$ & Hemicryp. & 0 & 0 & 0 & 1 & 1 & 1 & 0 & 0 & 0 & 1 & 0 & 1 & 0 & 1 & 0 & 1 & 0 & 1 \\
\hline Epilobium montanum & Native & $\mathrm{N}$ & Hemicryp. & 0 & 0 & 0 & 0 & 1 & 1 & 0 & 0 & 0 & 0 & 0 & 0 & 1 & 1 & 0 & 0 & 0 & 0 \\
\hline Epilobium species & Native & $\mathrm{N}$ & Hemicryp. & 0 & 0 & 1 & 0 & 0 & 0 & 0 & 0 & 0 & 0 & 0 & 0 & 0 & 0 & 0 & 0 & 0 & 0 \\
\hline Equisetum arvense & Native & A & Geophyte & 0 & 1 & 0 & 1 & 0 & 1 & 0 & 0 & 1 & 1 & 0 & 1 & 1 & 1 & 0 & 0 & 0 & 1 \\
\hline Erigeron acris & Native & Gen. & Theroph. & 0 & 0 & 0 & 0 & 1 & 0 & 0 & 0 & 0 & 0 & 0 & 0 & 1 & 0 & 0 & 0 & 0 & 0 \\
\hline Euphorbia exigua & Arch. & A & Theroph. & 2 & 3 & 0 & 0 & 1 & 2 & 0 & 0 & 0 & 0 & 0 & 0 & 0 & 0 & 0 & 0 & 0 & 0 \\
\hline Euphorbia helioscopia & Arch. & A & Theroph. & 2 & 3 & 0 & 1 & 0 & 2 & 0 & 0 & 0 & 0 & 1 & 1 & 1 & 0 & 0 & 0 & 0 & 0 \\
\hline Fallopia convolvulus & Arch. & A & Theroph. & 2 & 3 & 0 & 0 & 2 & 1 & 0 & 0 & 0 & 1 & 0 & 0 & 1 & 3 & 0 & 0 & 0 & 1 \\
\hline Festuca pratensis & Native & $\mathrm{G}$ & Hemicryp. & 1 & 0 & 0 & 0 & 0 & 0 & 0 & 0 & 0 & 0 & 0 & 1 & 0 & 0 & 0 & 0 & 0 & 0 \\
\hline Fragaria vesca & Native & Gen. & Hemicryp. & 0 & 0 & 0 & 0 & 1 & 0 & 0 & 0 & 0 & 0 & 0 & 0 & 0 & 0 & 0 & 0 & 0 & 0 \\
\hline Fumaria officinalis & Arch. & A & Theroph. & 2 & 3 & 0 & 0 & 2 & 2 & 0 & 0 & 0 & 0 & 0 & 0 & 0 & 1 & 0 & 0 & 0 & 0 \\
\hline Fumaria species & Arch. & $\mathrm{A}$ & Theroph. & 0 & 0 & 0 & 0 & 0 & 1 & 0 & 0 & 0 & 0 & 0 & 0 & 0 & 1 & 0 & 0 & 0 & 0 \\
\hline Fumaria vaillantii & Arch. & A & Theroph. & 1 & 0 & 0 & 0 & 0 & 0 & 0 & 0 & 0 & 0 & 0 & 0 & 1 & 0 & 0 & 0 & 0 & 0 \\
\hline Galium album & Native & Gen. & Hemicryp. & 0 & 0 & 1 & 0 & 1 & 0 & 0 & 0 & 0 & 0 & 1 & 1 & 1 & 1 & 0 & 1 & 0 & 2 \\
\hline Galium aparine & Native & A & Theroph. & 3 & 2 & 3 & 3 & 3 & 3 & 1 & 1 & 0 & 2 & 3 & 2 & 3 & 3 & 1 & 1 & 1 & 2 \\
\hline Geranium dissectum & Arch. & A & Theroph. & 0 & 0 & 0 & 0 & 0 & 0 & 0 & 0 & 0 & 0 & 1 & 0 & 1 & 1 & 0 & 0 & 0 & 0 \\
\hline Geranium pusillum & Arch. & $\mathrm{A}$ & Theroph. & 2 & 2 & 2 & 1 & 2 & 0 & 0 & 0 & 0 & 0 & 2 & 3 & 2 & 2 & 0 & 0 & 0 & 0 \\
\hline Geum urbanum & Native & $\mathrm{N}$ & Hemicryp. & 0 & 0 & 0 & 0 & 0 & 0 & 0 & 0 & 1 & 1 & 0 & 0 & 0 & 0 & 0 & 1 & 0 & 1 \\
\hline Glechoma hederacea & Native & $\mathrm{G}$ & Geophyte & 0 & 0 & 0 & 0 & 0 & 0 & 0 & 0 & 0 & 2 & 0 & 0 & 0 & 0 & 0 & 1 & 0 & 1 \\
\hline Helianthus annuus & Neoph. & Gen. & Theroph. & 1 & 0 & 0 & 0 & 0 & 0 & 0 & 0 & 0 & 0 & 0 & 0 & 0 & 0 & 0 & 0 & 0 & 0 \\
\hline
\end{tabular}




\begin{tabular}{|c|c|c|c|c|c|c|c|c|c|c|c|c|c|c|c|c|c|c|c|c|c|}
\hline & & & \multirow{5}{*}{$\begin{array}{l}\text { Position } \\
\text { Age (yrs.) } \\
\text { Season } \\
\text { Tree species }\end{array}$} & \multirow{5}{*}{\multicolumn{2}{|c|}{$\begin{array}{ll}\text { In } & \text { In } \\
1 & 1 \\
\mathrm{Su} & \mathrm{Su} \\
\mathrm{P} & \mathrm{W}\end{array}$}} & \multirow{5}{*}{$\begin{array}{l}\text { In } \\
2 \\
\mathrm{Sp} \\
\mathrm{P}\end{array}$} & \multirow{5}{*}{$\begin{array}{l}\text { In } \\
2 \\
\text { Sp } \\
\text { W }\end{array}$} & \multirow{5}{*}{$\begin{array}{l}\text { In } \\
2 \\
\mathrm{Su} \\
\mathrm{P}\end{array}$} & \multirow{5}{*}{$\begin{array}{l}\text { In } \\
2 \\
\mathrm{Su} \\
\mathrm{W}\end{array}$} & \multirow{5}{*}{$\begin{array}{l}\text { In } \\
5-8 \\
\text { Sp } \\
P\end{array}$} & \multirow{5}{*}{$\begin{array}{l}\text { In } \\
5-8 \\
\text { Sp } \\
\text { W }\end{array}$} & \multirow{5}{*}{$\begin{array}{l}\mathrm{In} \\
5-8 \\
\mathrm{Su} \\
\mathrm{P}\end{array}$} & \multirow{5}{*}{$\begin{array}{l}\mathrm{In} \\
5-8 \\
\mathrm{Su} \\
\mathrm{W}\end{array}$} & \multirow{5}{*}{\begin{tabular}{|l|} 
Ed \\
2 \\
Sp \\
$\mathrm{P}$
\end{tabular}} & \multirow{5}{*}{$\begin{array}{l}\text { Ed } \\
2 \\
\text { Sp } \\
W\end{array}$} & \multirow{5}{*}{$\begin{array}{l}\mathrm{Ed} \\
2 \\
\mathrm{Su} \\
\mathrm{P}\end{array}$} & \multirow{5}{*}{$\begin{array}{l}\mathrm{Ed} \\
2 \\
\mathrm{Su} \\
\mathrm{W}\end{array}$} & \multirow{5}{*}{$\begin{array}{l}\mathrm{Ed} \\
5-8 \\
\mathrm{Sp} \\
\mathrm{P}\end{array}$} & \multirow{5}{*}{$\begin{array}{l}\text { Ed } \\
5-8 \\
\text { Sp } \\
W\end{array}$} & \multirow{5}{*}{$\begin{array}{l}\mathrm{Ed} \\
5-8 \\
\mathrm{Su} \\
\mathrm{P}\end{array}$} & \multirow{5}{*}{$\begin{array}{l}\mathrm{Ed} \\
5-8 \\
\mathrm{Su} \\
\mathrm{W}\end{array}$} \\
\hline & & & & & & & & & & & & & & & & & & & & & \\
\hline & & & & & & & & & & & & & & & & & & & & & \\
\hline & & & & & & & & & & & & & & & & & & & & & \\
\hline & & & & & & & & & & & & & & & & & & & & & \\
\hline & & & $\begin{array}{l}\text { Tot. \# of } \\
\text { SRCs }\end{array}$ & 3 & 3 & 3 & 3 & 3 & 3 & 1 & 1 & 2 & 2 & 3 & 3 & 3 & 3 & 1 & 1 & 1 & 2 \\
\hline Species & Status & $\begin{array}{l}\text { Hab. } \\
\text { pref. }\end{array}$ & Life form & & & & & & & & & & & & & & & & & & \\
\hline Helianthus tuberosus & Neoph. & Gen. & Geophyte & 0 & 0 & 0 & 0 & 0 & 0 & 0 & 0 & 0 & 0 & 0 & 0 & 0 & 0 & 0 & 0 & 0 & 1 \\
\hline Heracleum sphondylium & Native & $\mathrm{N}$ & Hemicryp. & 0 & 0 & 0 & 0 & 0 & 0 & 0 & 0 & 0 & 0 & 0 & 0 & 1 & 0 & 0 & 0 & 0 & 0 \\
\hline Hieracium lachenalii & Native & Gen. & Hemicryp. & 0 & 0 & 0 & 0 & 1 & 0 & 0 & 0 & 0 & 0 & 0 & 0 & 0 & 0 & 0 & 0 & 0 & 0 \\
\hline Holcus lanatus & Native & $\mathrm{G}$ & Hemicryp. & 0 & 0 & 1 & 0 & 0 & 0 & 0 & 0 & 0 & 0 & 1 & 0 & 0 & 0 & 0 & 0 & 0 & 0 \\
\hline Holcus mollis & Native & Gen. & Geophyte & 0 & 0 & 0 & 0 & 0 & 0 & 0 & 0 & 0 & 0 & 1 & 0 & 0 & 0 & 0 & 0 & 0 & 0 \\
\hline Hypericum perforatum & Native & Gen. & Hemicryp. & 0 & 0 & 1 & 0 & 1 & 0 & 0 & 0 & 0 & 1 & 0 & 0 & 1 & 0 & 0 & 0 & 0 & 1 \\
\hline Lactuca serriola & Native & A & Theroph. & 0 & 0 & 2 & 3 & 2 & 3 & 0 & 0 & 0 & 0 & 1 & 2 & 2 & 3 & 0 & 0 & 0 & 1 \\
\hline Lamium amplexicaule & Arch. & A & Theroph. & 1 & 1 & 2 & 1 & 1 & 0 & 0 & 0 & 0 & 0 & 1 & 2 & 0 & 0 & 0 & 0 & 0 & 0 \\
\hline Lamium purpureum & Arch. & A & Theroph. & 0 & 1 & 0 & 1 & 0 & 1 & 0 & 0 & 0 & 0 & 0 & 1 & 1 & 0 & 0 & 1 & 0 & 1 \\
\hline Lathyrus tuberosus & Native & A & Hemicryp. & 0 & 0 & 0 & 0 & 0 & 0 & 0 & 0 & 0 & 0 & 0 & 0 & 1 & 0 & 0 & 0 & 0 & 1 \\
\hline Lepidium ruderale & Arch. & Gen. & Theroph. & 0 & 0 & 0 & 0 & 0 & 0 & 0 & 0 & 0 & 0 & 0 & 0 & 1 & 0 & 0 & 0 & 0 & 0 \\
\hline Lolium perenne & Native & $\mathrm{G}$ & Hemicryp. & 0 & 0 & 0 & 0 & 0 & 0 & 0 & 0 & 0 & 0 & 1 & 0 & 1 & 0 & 0 & 0 & 0 & 0 \\
\hline Malva neglecta & Arch. & A & Theroph. & 0 & 0 & 1 & 1 & 0 & 1 & 0 & 0 & 0 & 0 & 2 & 1 & 1 & 1 & 0 & 0 & 0 & 0 \\
\hline Matricaria recutita & Arch. & $\mathrm{A}$ & Theroph. & 1 & 1 & 0 & 0 & 1 & 1 & 0 & 0 & 0 & 0 & 1 & 0 & 1 & 1 & 0 & 0 & 0 & 0 \\
\hline Matricaria species & Arch. & A & Theroph. & 0 & 0 & 0 & 1 & 0 & 0 & 0 & 0 & 0 & 0 & 0 & 1 & 0 & 0 & 0 & 0 & 0 & 0 \\
\hline Medicago lupulina & Native & A & Theroph. & 0 & 1 & 0 & 0 & 2 & 1 & 0 & 0 & 0 & 0 & 1 & 0 & 1 & 2 & 0 & 0 & 0 & 0 \\
\hline Milium effuSu & Native & $\mathrm{F}$ & Hemicryp. & 0 & 0 & 0 & 0 & 0 & 0 & 0 & 0 & 0 & 1 & 0 & 0 & 0 & 0 & 0 & 0 & 0 & 1 \\
\hline Mycelis muralis & Native & $\mathrm{N}$ & Hemicryp. & 0 & 0 & 0 & 0 & 0 & 1 & 0 & 0 & 0 & 0 & 0 & 0 & 0 & 0 & 0 & 0 & 0 & 0 \\
\hline Myosotis arvensis & Arch. & $\mathrm{A}$ & Theroph. & 2 & 1 & 2 & 1 & 2 & 1 & 0 & 0 & 0 & 0 & 1 & 1 & 1 & 2 & 0 & 0 & 0 & 0 \\
\hline Onopordum acanthium & Arch. & $\mathrm{N}$ & Hemicryp. & 0 & 2 & 1 & 1 & 0 & 1 & 0 & 0 & 0 & 0 & 1 & 2 & 1 & 2 & 0 & 0 & 0 & 0 \\
\hline Papaver dubium & Arch. & A & Theroph. & 0 & 0 & 0 & 0 & 0 & 1 & 0 & 0 & 0 & 0 & 0 & 0 & 0 & 0 & 0 & 0 & 0 & 0 \\
\hline Papaver rhoeas & Arch. & A & Theroph. & 1 & 1 & 2 & 2 & 3 & 2 & 0 & 0 & 0 & 0 & 2 & 1 & 2 & 2 & 0 & 0 & 0 & 1 \\
\hline
\end{tabular}




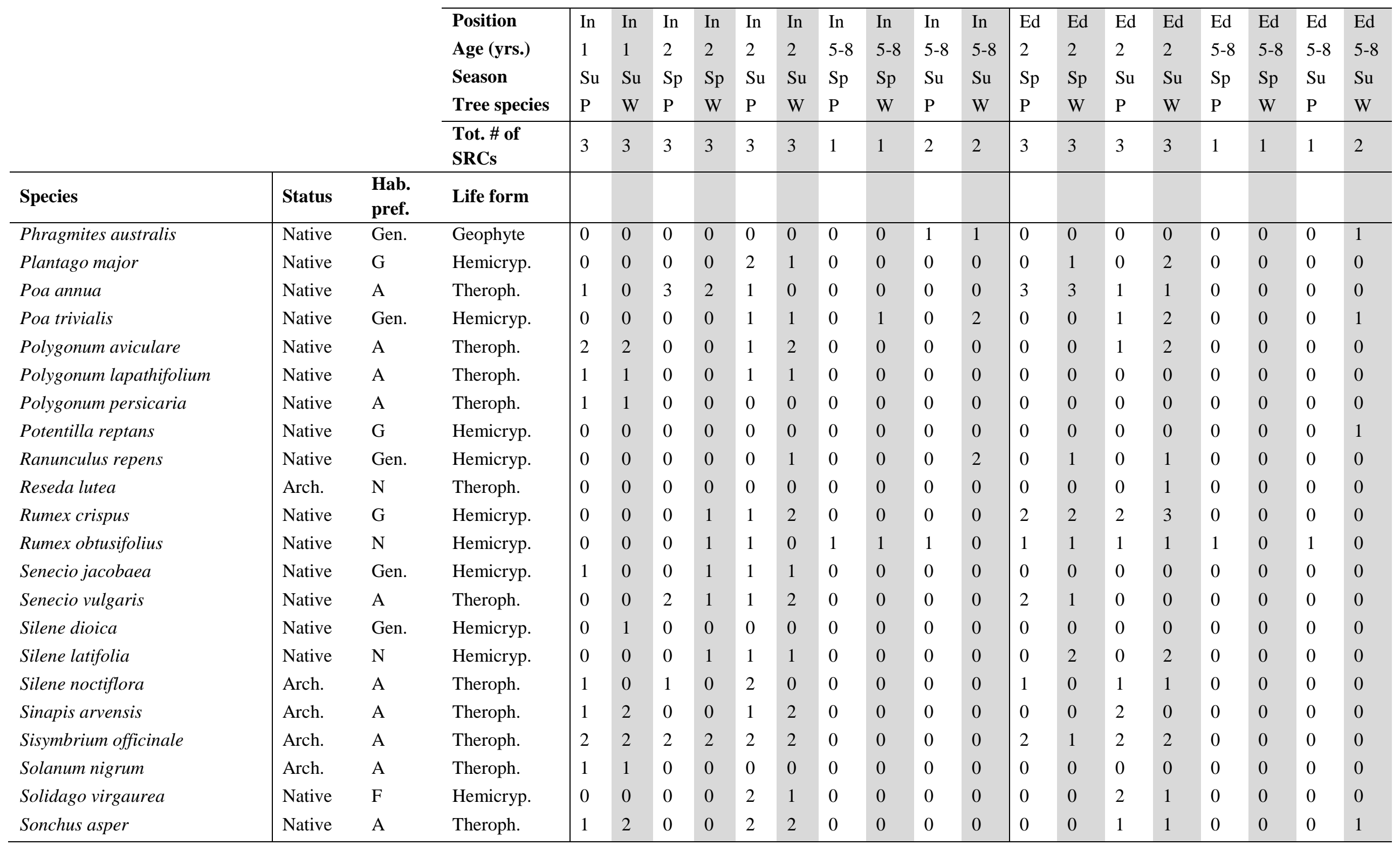




\begin{tabular}{|c|c|c|c|c|c|c|c|c|c|c|c|c|c|c|c|c|c|c|c|c|c|}
\hline & & & \multirow{4}{*}{$\begin{array}{l}\text { Position } \\
\text { Age (yrs.) } \\
\text { Season } \\
\text { Tree species }\end{array}$} & \multirow{4}{*}{\multicolumn{2}{|c|}{$\begin{array}{ll}\text { In } & \text { In } \\
1 & 1 \\
\mathrm{Su} & \mathrm{Su} \\
\mathrm{P} & \mathrm{W}\end{array}$}} & \multirow{4}{*}{$\begin{array}{l}\text { In } \\
2 \\
\mathrm{Sp} \\
\mathrm{P}\end{array}$} & \multirow{4}{*}{$\begin{array}{l}\text { In } \\
2 \\
\mathrm{Sp} \\
\mathrm{W}\end{array}$} & \multirow{4}{*}{$\begin{array}{l}\mathrm{In} \\
2 \\
\mathrm{Su} \\
\mathrm{P}\end{array}$} & \multirow{4}{*}{$\begin{array}{l}\text { In } \\
2 \\
\mathrm{Su} \\
\mathrm{W}\end{array}$} & \multirow{4}{*}{$\begin{array}{l}\text { In } \\
5-8 \\
\mathrm{Sp} \\
\mathrm{P}\end{array}$} & \multirow{4}{*}{$\begin{array}{l}\text { In } \\
5-8 \\
\text { Sp } \\
\text { W }\end{array}$} & \multirow{4}{*}{$\begin{array}{l}\mathrm{In} \\
5-8 \\
\mathrm{Su} \\
\mathrm{P}\end{array}$} & \multirow{4}{*}{$\begin{array}{l}\text { In } \\
5-8 \\
\mathrm{Su} \\
\mathrm{W}\end{array}$} & \multirow{4}{*}{$\begin{array}{l}\mathrm{Ed} \\
2 \\
\mathrm{Sp} \\
\mathrm{P}\end{array}$} & \multirow{4}{*}{$\begin{array}{l}\mathrm{Ed} \\
2 \\
\mathrm{Sp} \\
\mathrm{W}\end{array}$} & \multirow{4}{*}{$\begin{array}{l}\mathrm{Ed} \\
2 \\
\mathrm{Su} \\
\mathrm{P}\end{array}$} & \multirow{4}{*}{$\begin{array}{l}\mathrm{Ed} \\
2 \\
\mathrm{Su} \\
\mathrm{W}\end{array}$} & \multirow{4}{*}{$\begin{array}{l}\text { Ed } \\
5-8 \\
\mathrm{Sp} \\
\mathrm{P}\end{array}$} & \multirow{4}{*}{$\begin{array}{l}\text { Ed } \\
5-8 \\
\text { Sp } \\
\text { W }\end{array}$} & \multirow{4}{*}{$\begin{array}{l}\mathrm{Ed} \\
5-8 \\
\mathrm{Su} \\
\mathrm{P}\end{array}$} & \multirow{4}{*}{$\begin{array}{l}\mathrm{Ed} \\
5-8 \\
\mathrm{Su} \\
\mathrm{W}\end{array}$} \\
\hline & & & & & & & & & & & & & & & & & & & & & \\
\hline & & & & & & & & & & & & & & & & & & & & & \\
\hline & & & & & & & & & & & & & & & & & & & & & \\
\hline & & & $\begin{array}{l}\text { Tot. \# of } \\
\text { SRCs }\end{array}$ & 3 & 3 & 3 & 3 & 3 & 3 & 1 & 1 & 2 & 2 & 3 & 3 & 3 & 3 & 1 & 1 & 1 & 2 \\
\hline Species & Status & $\begin{array}{l}\text { Hab. } \\
\text { pref. }\end{array}$ & Life form & & & & & & & & & & & & & & & & & & \\
\hline Sonchus oleraceus & Native & A & Theroph. & 1 & 0 & 0 & 0 & 0 & 0 & 0 & 0 & 0 & 0 & 0 & 0 & 1 & 0 & 0 & 0 & 0 & 0 \\
\hline Sonchus species & Native & A & Theroph. & 0 & 0 & 0 & 0 & 0 & 1 & 0 & 0 & 0 & 0 & 0 & 0 & 0 & 2 & 0 & 0 & 0 & 0 \\
\hline Stachys palustris & Native & $\mathrm{G}$ & Geophyte & 0 & 0 & 0 & 0 & 0 & 0 & 0 & 0 & 1 & 1 & 0 & 0 & 0 & 0 & 0 & 0 & 0 & 1 \\
\hline Stellaria media & Arch. & $\mathrm{A}$ & Theroph. & 1 & 0 & 2 & 1 & 1 & 0 & 0 & 0 & 0 & 0 & 2 & 2 & 1 & 1 & 0 & 0 & 0 & 0 \\
\hline Symphytum officinale & Native & Gen. & Hemicryp. & 0 & 0 & 0 & 0 & 0 & 0 & 0 & 0 & 0 & 1 & 0 & 0 & 0 & 0 & 0 & 0 & 0 & 1 \\
\hline Taraxacum species & Native & Gen. & Hemicryp. & 0 & 0 & 3 & 3 & 3 & 3 & 0 & 1 & 0 & 0 & 3 & 3 & 3 & 3 & 1 & 1 & 0 & 0 \\
\hline Thlaspi arvense & Arch. & A & Theroph. & 1 & 2 & 1 & 1 & 1 & 1 & 0 & 0 & 0 & 0 & 2 & 3 & 1 & 2 & 0 & 0 & 0 & 0 \\
\hline Torilis japonica & Native & $\mathrm{N}$ & Hemicryp. & 0 & 0 & 0 & 0 & 1 & 1 & 0 & 0 & 1 & 2 & 0 & 0 & 2 & 1 & 0 & 0 & 0 & 2 \\
\hline Trifolium pratense & Native & $\mathrm{G}$ & Hemicryp. & 0 & 0 & 0 & 0 & 0 & 0 & 0 & 0 & 0 & 0 & 0 & 1 & 0 & 1 & 0 & 0 & 0 & 0 \\
\hline Trifolium repens & Native & G & Hemicryp. & 0 & 0 & 0 & 1 & 0 & 0 & 0 & 0 & 0 & 0 & 1 & 1 & 1 & 1 & 0 & 0 & 0 & 0 \\
\hline Tripleurospermum perforatum & Arch. & A & Theroph. & 3 & 3 & 3 & 3 & 3 & 3 & 0 & 0 & 0 & 0 & 3 & 3 & 3 & 3 & 0 & 0 & 0 & 0 \\
\hline Tussilago farfara & Native & $\mathrm{N}$ & Hemicryp. & 0 & 0 & 0 & 0 & 1 & 0 & 0 & 0 & 0 & 0 & 0 & 0 & 0 & 0 & 0 & 0 & 0 & 0 \\
\hline Urtica dioica & Native & $\mathrm{N}$ & Chamaeph. & 0 & 0 & 0 & 0 & 0 & 0 & 1 & 1 & 2 & 2 & 0 & 1 & 0 & 1 & 0 & 1 & 0 & 2 \\
\hline Veronica arvensis & Arch. & A & Theroph. & 0 & 0 & 0 & 0 & 1 & 0 & 0 & 0 & 0 & 0 & 0 & 0 & 1 & 1 & 0 & 0 & 0 & 0 \\
\hline Veronica persica & Neoph. & A & Theroph. & 1 & 1 & 1 & 1 & 1 & 1 & 0 & 1 & 0 & 0 & 2 & 2 & 2 & 2 & 0 & 0 & 0 & 0 \\
\hline Veronica polita & Arch. & A & Theroph. & 1 & 1 & 1 & 1 & 1 & 0 & 0 & 0 & 0 & 0 & 2 & 1 & 1 & 1 & 0 & 0 & 0 & 0 \\
\hline Vicia cracca & Native & G & Hemicryp. & 0 & 0 & 0 & 0 & 0 & 0 & 0 & 0 & 0 & 1 & 0 & 0 & 0 & 0 & 0 & 0 & 0 & 1 \\
\hline Vicia tetrasperma & Native & A & Theroph. & 0 & 0 & 0 & 0 & 0 & 0 & 0 & 0 & 0 & 0 & 0 & 0 & 1 & 0 & 0 & 0 & 0 & 0 \\
\hline Viola arvensis & Arch. & A & Theroph. & 2 & 3 & 3 & 3 & 2 & 3 & 0 & 0 & 0 & 0 & 3 & 3 & 3 & 3 & 0 & 0 & 0 & 0 \\
\hline \multicolumn{22}{|l|}{ Trees \& shrubs } \\
\hline Acer campestre & Native & $\mathrm{F}$ & Phaneroph. & 0 & 1 & 0 & 0 & 0 & 0 & 0 & 0 & 0 & 0 & 0 & 0 & 1 & 1 & 0 & 0 & 1 & 0 \\
\hline Acer negundo & Neoph. & $\mathrm{F}$ & Phaneroph. & 0 & 0 & 0 & 0 & 0 & 0 & 0 & 0 & 0 & 0 & 0 & 0 & 0 & 0 & 0 & 0 & 0 & 1 \\
\hline
\end{tabular}




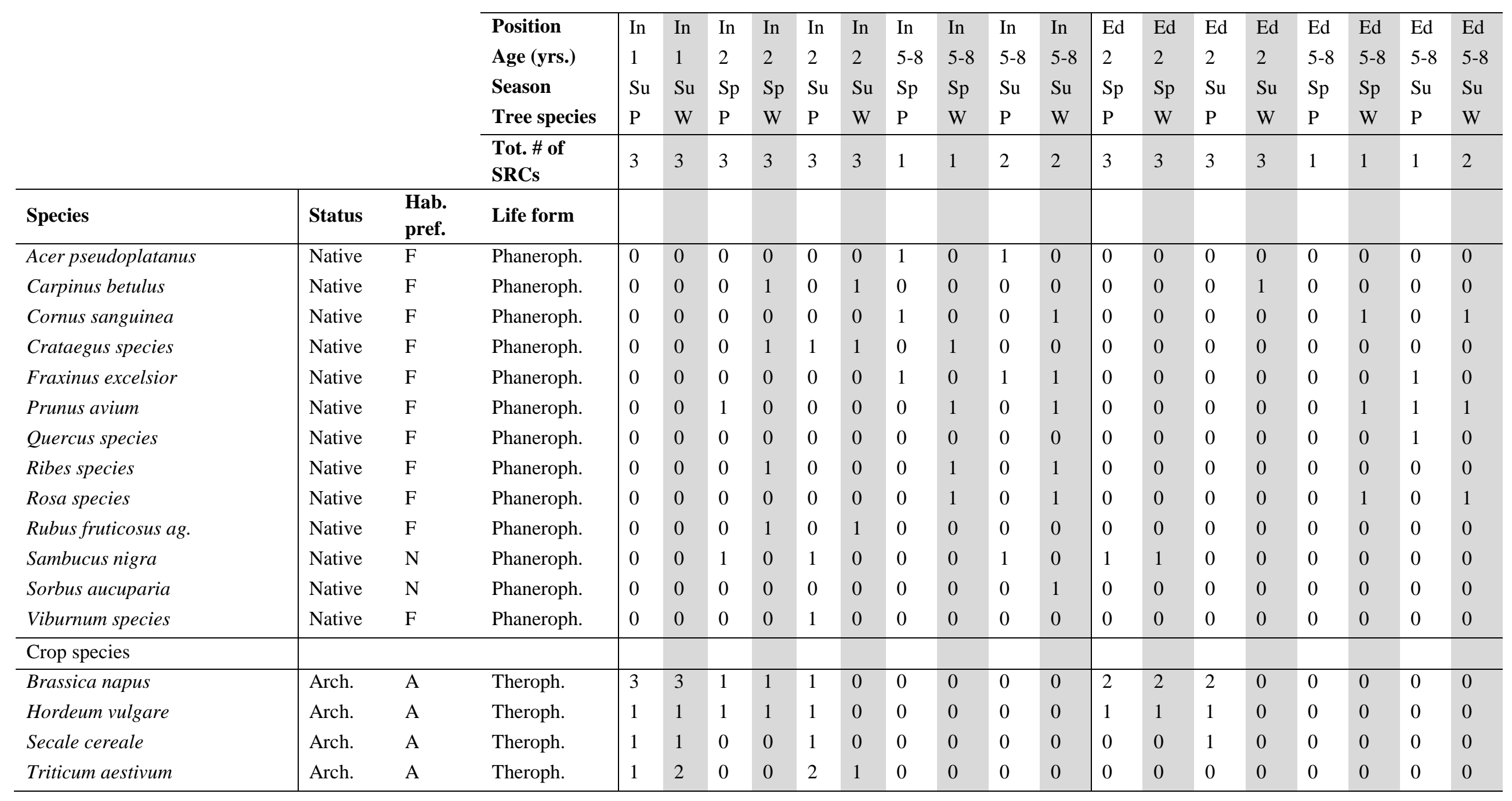




\section{$\underline{\text { Further publications }}$}

Peer-reviewed journals

Waltert, M., Seifert, C., Radl, G., Hoppe-Dominik, B. (2010) Population size and habitat of the White-breasted Guineafowl Agelastes meleagrides in the Taï region, Côte d'Ivoire. Bird Conservation International 20, 74-83.

\section{Other publications}

BfN (2014) Grünland-Report - Alles im Grünen Bereich? Becker, N., Emde, F., Jessel, B., Kärcher, A., Schuster, B, Seifert, C. (eds); Available at: http://www.bfn.de/fileadmin/MDB/documents/ presse/2014/PK_Gruenlandpapier_30.06.2014_final_layout_barrierefrei.pdf, last accessed 25/07/2014.

Klein, M., Seifert, C. (2014) Agricultural biodiversity and traditional practices as reflected in the European Common Agricultural Policy. In: Kohsaka, R., Thompson, I. D. (eds); Conference proceedings 'Sustainable management including the use of traditional knowledge in Satoyama and other SEPLS', 1-3 May 2014, Kanazawa University School of Regional Development Studies, Ishikawa, Japan, pp. 47-56.

Seifert, C. (2013) Auswirkung des Anbaus von Bioenergiepflanzen auf die Pflanzenartenvielfalt der Agrarlandschaft in Südniedersachsen und im Thüringer Becken. In: Feit, U. \& Korn, H. (eds); Treffpunkt Biologische Vielfalt XII - Interdisziplinärer Forschungsaustausch im Rahmen des Übereinkommens über die biologische Vielfalt. BfN-Skripten 335, 71-76. 


\section{Eigenständigkeitserklärung}

Hiermit bestätige ich die vorliegende Dissertationsschrift eigenständig verfasst und keine anderen als die im Text angegebenen Quellen und Hilfsmittel verwendet zu haben.

Ort, Datum, Unterschrift 